Universidade de São Paulo

FLAVI A REJ ANE PRANDO

\title{
Othon Salleiro: Um Barrios Brasileiro? Análise da linguagem instrumental do compositor-violonista. ( 1910 - 1999)
}

\begin{abstract}
Dissertação apresentada ao Programa de Pós-Graduação em Música, Área de Concentração Processo de Criação Musical, Linha de Pesquisa Técnicas Composicionais e Questões interpretativas da Escola de Comunicações e Artes da Universidade de São Paulo, como exigência parcial para obtenção do Título de Mestre em Música, sob a orientação do Prof. Dr. Edelton Gloeden.
\end{abstract}




\title{
FLAVIA REJ ANE PRANDO
}

\section{Othon Salleiro: Um Barrios Brasileiro? Análise da linguagem instrumental do compositor-violonista. ( 1910 - 1999)}

\begin{abstract}
Dissertação apresentada ao Programa de Pós-Graduação em Música, Área de Concentração Processo de Criação Musical, Linha de Pesquisa Técnicas Composicionais e Questões interpretativas da Escola de Comunicações e Artes da Universidade de São Paulo, como exigência parcial para obtenção do Título de Mestre em Música, sob a orientação do Prof. Dr. Edelton Gloeden.
\end{abstract}


Othon Salleiro: Um Barrios Brasileiro? Análise da linguagem instrumental do compositor-violonista (1910-1999)

Flavia Rejane Prando

Orientador: Prof. Dr. Edelton Gloeden.

Dissertação apresentada ao Programa de Pós-Graduação em Música da Escola de Comunicações e Artes da Universidade de São Paulo, como exigência parcial para obtenção do Título de Mestre em Música.

Prof.Dr.Edelton Gloeden

Prof.Dr.

Prof.Dr.

São Paulo 2008 


\section{Resumo}

Este trabalho tem como objeto a obra do violonista Othon Salleiro (1910-1999). O objetivo desta pesquisa é analisar, recuperar e contextualizar a produção do compositor carioca dentro do panorama do violão popular brasileiro. Através da apreciação de sua obra, da transcrição das gravações disponíveis e da análise comparativa dos violonistas compositores do mesmo período, procuramos traçar a identidade composicional e instrumental de Othon Salleiro.

Lembramos que se trata de uma produção exclusivamente para violão solo. Além da catalogação das obras encontradas, a confecção das partituras foi a nossa contribuição para recuperar e divulgar a obra deste importante compositor do cenário do violão popular brasileiro.

Palavras chave: Othon Salleiro, música brasileira, violão popular, recuperação de partituras, catálogo. 


\begin{abstract}
This study focuses on the work of guitarist Othon Salleiro (19101999). The purpose of this study is to analyze, recover and provide context for the work produced by the composer from Rio de Janeiro within the scenario of Brazilian popular guitar music. By examining his work, transcribing available recordings and doing a comparative analysis of composer guitarists of the same period we tried to outline the composing and instrumental identity of Othon Salleiro. We remind you that his work is exclusively for solo guitar. In addition to cataloguing the music found, making sheet music was our contribution to recover and make known the work of this important Brazilian popular guitar composer.
\end{abstract}

Keywords: Othon Salleiro, Brazilian music, popular guitar, recovering sheet music, catalogue. 


\section{Agradecimentos}

A Edelton Gloeden, orientador desta dissertação, pelo apoio, disponibilidade e, sobretudo, paciência.

Agradecemos ainda a Nélio Rodrigues, Marialva Barbosa, Nicanor Teixeira, Nicolas Barros, Ronoel Simões, Maria Salleiro, Regina Salleiro, Múcio Carias, Alberto Valle, Jodacil Damasceno, Octavio Machado, Vera de Andrade, Maria Haro, Sofia de Andrade, Miguel Paladino, Danilo Oliveira, Fabio Zanon, Paola Picherzky, Gilson Antunes e Marcia Taborda.

Agradecimentos especiais à valiosa colaboração de Ruy Weber na confecção das partituras deste trabalho. 
A Ronoel Simões, que dedicou sua vida à preservação da história do violão. 


\section{SUMÁRIO}

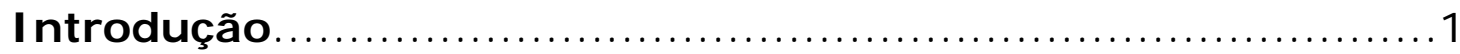

1. O Violão Brasileiro (1808 - 1914): Aspectos Sociais.........8

2. A Reabilitação do Violão Brasileiro ( 1914 - 1930) ...........22

3. O Violão no Rio de Janeiro ( 1868 - 1950)

3.1 Precursores de Othon Salleiro............................50

3.2 Panorama violonístico na época de Othon Salleiro......67

4. Othon salleiro (1910 - 1999)

4.1 Othon Salleiro violonista e compositor..................80

4.2 Composições..............................................100

4.2.1 Catálogo das obras..........................108

4.2.2 Estilos composicionais na obra de Othon Salleiro.

4.2.3 Partituras

4.2.3.1 Editadas pela Casa Wehrs...114

4.2.3.2 Confeccionadas por Nélio

Rodrigues.....................129

4.2.3.3 Confeccionadas para a dissertação. 149

4.2.3.4

5. Conclusão

232

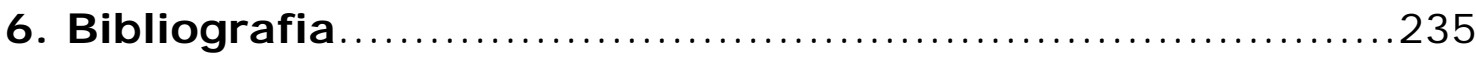

7. Anexos

Relação das Músicas do CD em anexo. 240 


\section{I ntrodução}

Podemos afirmar que a história do violão popular brasileiro ainda não foi totalmente escrita. Há um número considerável de violonistas e compositores cuja obra não foi recuperada, analisada ou avaliada. Entre aqueles que nasceram no final do século $X I X$ e no começo do século $X X$, podemos citar Rogério Guimarães, Benedito Chaves, Levino da Conceição, Mozart Bicalho, José Augusto de Freitas e Homero Alvarez, contemporâneos de Othon Salleiro (1910 - 1999).

Com o advento dos cursos de pós-graduação em música no Brasil, este panorama está se modificando. Os trabalhos sobre estes violonistas passam a constituir um esteio de possibilidades para pesquisas sobre 0 instrumento, iniciando assim a formação de bibliografia, ainda escassa, sobre $o$ assunto.

As Dissertações de Mestrado Américo J acomino "CANHOTO" e o desenvolvimento da arte solística do violão em São Paulo (2000), de Gilson Antunes e Armando Neves - Choro no Violão Paulista (2004), de Paola Picherzky são dois exemplos de trabalhos que apresentam semelhanças com a nossa pesquisa. Os dois têm como foco principal a recuperação da produção para violão solo de compositores-violonistas populares do período citado acima, e colaboraram na condução desta pesquisa.

Paralelamente a estes trabalhos não podemos deixar de mencionar o doutorado Violão e Identidade Nacional: Rio de Janeiro 1830-1930 (2004), 
de Marcia Ermelindo Taborda que trouxe mais a fundo os aspectos culturais e históricos para a compreensão da trajetória do violão na então capital do país.

A escolha do nosso objeto de pesquisa recai na audição do LP O Violão Brasileiro de Othon Salleiro, um registro raro, gravado na década de 40, que chamou nossa atenção pela técnica e interpretação apresentadas em execuções de grande desenvoltura. Neste LP, com dez obras, todas de autoria do violonista carioca, ouvimos composições de gêneros variados e de um grau de complexidade sem precedentes no panorama do violão popular brasileiro daquele momento.

Ao mesmo tempo, pudemos notar elementos musicais que se destacam e imprimem um caráter próprio ao compositor: o uso do trêmolo, a utilização de campanellas, o uso de harmônicos naturais e artificiais, o uso sistemático dos rasgueos, soluções harmônicas inesperadas e procedimentos diferenciados de scordatura, conforme veremos no decorrer deste trabalho.

A escassez de material sobre Salleiro, a qualidade musical das obras, e o fato de, apesar de possuir uma obra considerável, ser um compositor pouco conhecido, mesmo no ambiente violonístico, instigou-nos a pesquisar, sistematizar e analisar sua obra.

A quase inexistência de bibliografia sobre nosso objeto de pesquisa uma pequena biografia no livro sobre Dilermando Reis, de Genésio Nogueira (2000); um artigo na revista Violão e Mestres (1964); uma pequena citação em artigo (1956) de Hermínio Bello de Carvalho e uma 
citação no livro Música Popular Brasileira Estilizada de autoria de Henrique Pedrosa (1988) - fez com que centrássemos nossa pesquisa em duas frentes principais:

1. Esteio teórico:

1.1 Livros, dissertações e teses existentes sobre compositores contemporâneos de Othon Salleiro;

1.2 Livros sobre o assunto e o período abordados em nossa pesquisa;

2. Fontes primárias:

2.1 Consulta a acervos pessoais de violonistas que conviveram com Othon Salleiro;

2.2 Consulta ao acervo do próprio Salleiro;

2.3 Entrevistas com contemporâneos de Salleiro: Múcio Carias, Alberto Valle, Nicanor Teixeira, J odacil Damasceno, Maria Salleiro, Nélio Rodrigues e Ronoel Simões.

A curiosa citação de Hermínio Bello de Carvalho em Carta ao Poeta Manuel Bandeira (1956), respondendo ao ensaio do poeta, A Literatura do Violão (1956), textos que veremos mais detalhadamente adiante, gerou o primeiro capítulo desta pesquisa. Na tentativa de defesa do violão, frequentemente acusado de instrumento de capadócio, de malandro, Carvalho cita Othon Salleiro como exceção: 
(...) Nesse grupo não se incluía Othon Salleiro, também discípulo de Quincas Laranjeiras, psiquiatra que gravou um imperdível LP há mais de 10 anos, hoje raridade fonográfica.

O aparecimento do nome de Salleiro não para afirmar algo, mas para negá-lo nos chamou atenção. Salleiro era fruto da alta classe média carioca. Estudou no Colégio Santo Agostinho, reduto da elite local. Seu pai nunca quis vê-lo tocando violão profissionalmente, haveria de ser médico, pois violão era instrumento para desocupados. Esta mentalidade, que condicionou Salleiro a seguir como amador na música, instigou-nos a pesquisar as origens deste desprestígio social do instrumento, gerando o capítulo: O Violão Brasileiro (1808 - 1914): Aspectos Sociais.

No segundo capítulo, A Reabilitação do Violão Brasileiro (1914 1929), analisamos os processos que fizeram com que o violão começasse a ser aceito como instrumento de concerto e que transformaram completamente sua receptividade na sociedade brasileira.

No terceiro capítulo, O Violão no Rio de Janeiro (1868 - 1950), estabelecemos os critérios para o recorte de nossa pesquisa: o violão instrumental brasileiro. Tentamos rastrear o início da tradição do violão solo no país, mais precisamente no Rio de Janeiro. Através dos precursores e contemporâneos de Othon Salleiro, buscamos traçar parâmetros para melhor inserção da obra deste compositor no panorama do violão brasileiro. 
O quarto capítulo, além de um pequeno perfil biográfico, dedica-se mais especificamente à obra de Othon Salleiro, na tentativa de sistematização e organização da mesma.

Para a realização deste trabalho, contamos com a colaboração de violonistas e professores que tiveram contato direta ou indiretamente com Othon Salleiro: Nélio Rodrigues, Nicanor Teixeira, Nicolas de Souza Barros e Ronoel Simões.

Nicolas de Souza Barros (Uni-Rio) foi o nosso maior incentivador, chamando-nos a atenção para a necessidade de valorização e divulgação da obra de Salleiro. Barros contribuiu com este estudo realizando a transcrição de uma peça do disco O Violão Brasileiro de Othon Salleiro, a música Reminiscências Cariocas (2003), que nos foi gentilmente cedida. Esta partitura foi digitalizada para a presente pesquisa. Foi também Nicolas Barros quem nos apresentou a Nélio Rodrigues, o último violonista a realizar um trabalho de edição, revisão e gravação das obras de Salleiro, conforme veremos neste quarto capítulo.

Nélio Rodrigues generosamente colocou todas as informações e materiais concernentes a Othon Salleiro à nossa disposição: gravações, programas, partituras digitalizadas e manuscritos. Este material foi o ponto de partida para nosso escrutínio.

Dentre as partituras cedidas por Rodrigues, destacamos as que utilizamos neste estudo: Sonhando na Rede - suposta parceira de Othon Salleiro e J oão Pernambuco; Batuque - parceria de Salleiro com J oão dos Santos; Choro Seresteiro - parceria de Salleiro com Eduardo da Piedade; 
duas partituras inéditas: Miudinho Chegadinho e Dança Árabe, além de Ansiedade, música que foi editada e gravada por Nélio Rodrigues. Optamos por utilizar somente as obras imprescindíveis para a compreensão desta pesquisa, uma vez que Nélio Rodrigues fez a edição e gravação comercial de dezoito obras de Salleiro, conforme veremos adiante. Rodrigues também forneceu-nos um roteiro para as entrevistas indicando-nos dois contemporâneos vivos de Salleiro: Alberto Valle e Múcio Carias.

Nicanor Teixeira, conforme trataremos adiante, foi o primeiro violonista a fazer transcrições sistemáticas da obra de Salleiro. Infelizmente, a maioria das partituras foi extraviada. No LP O Violão Brasileiro de Nicanor Teixeira, Teixeira gravou uma música de Othon Salleiro, a Berceuse, cuja partitura foi transcrita para a presente pesquisa. Teixeira cedeu-nos quatro manuscritos. São partituras que foram anotadas e digitadas pelo violonista baiano, a partir da execução do compositor. São elas: Prelúdio Carioca, Diálogo Amoroso, Prece e Cavaquinho em Serenata.

Por sua vez, Ronoel Simões, pesquisador e colecionador de partituras e gravações de violão, esteve presente na gravação que Salleiro realizou no estúdio da RGE, em São Paulo, em 14 de abril de 1950. Estas gravações não chegaram a circular comercialmente e trazem músicas inéditas de Salleiro: Quebra-Coco; Toada Sertaneja; Repinicado de Viola; Allegro Caprichoso e a valsa Falando-Ihe de Amor, além da música Devaneio que na edição de Nélio Rodrigues aparece com o nome de 
Conversando com o Infinito. As partituras foram confeccionadas para este trabalho a partir da referida gravação do compositor.

Localizamos trinta e três composições de Othon Salleiro. Destas, apenas seis foram editadas pelo compositor pela extinta Casa Wehrs: Coração Boêmio, Harmonia e Picardia, Dansa Infantil, Perfume da Saudade, Caixinha de Música e Súplicas de Amor.

Tendo sido o LP Violão Brasileiro de Othon Salleiro o motivador deste estudo, optamos por realizar as partituras destas obras a partir da referida gravação. Foram dez partituras confeccionadas a partir deste registro.

Para uma melhor compreensão da obra de Salleiro, fizemos uma primeira catalogação de suas composições, organizando o material utilizado e recuperado neste trabalho.

Julgamos que a confecção destas partituras é o cerne da contribuição da presente pesquisa. Salleiro não compunha pensando na escrita musical, o que dificulta sobremaneira o trabalho da transcrição de suas músicas. Nosso empenho foi no sentido de recuperar esta obra com vistas na interpretação do compositor. Buscamos, na medida do possível, manter as características de execução através de variantes grafáveis, sem, contudo, dificultar a leitura destas obras, possibilitando que futuramente os violonistas possam conhecer e divulgar as mesmas. 


\section{O Violão Brasileiro (1808 - 1914): Aspectos Sociais}

Por entendermos que a produção de Othon Salleiro tem uma forte ligação com elementos da música popular do século XIX e por esta obra estar inserida na tradição do violão popular brasileiro, julgamos pertinente a inserção do presente capítulo, abordando aspectos sociais deste período.

Gonzaga Duque (1863-1911) ${ }^{1}$ descreveu o tipo perfeito do violeiro, ainda no tempo dos vice-reis (1763-1808), no século XVIII:

Nas enluaradas noites de verão as famílias andavam em ranchos pelas ruas até alta noite (...), sentavam-se no caes para ouvir a musica que o vice-rei mandava tocar, e ali, homens, mulheres e crianças, gozavam as melodias do 'lundu de monroi'. Ao soprar cálido das virações marinhas, sussurrando na cabelleira das arvores, ao clarão da lua, passavam as bellas-noite, ouvindo o tanger da viola, d'algum trovador de ganga, acompanhando a popular canção deste tempo:

'Vou me embora, vou me embora.

É mentira, não vou, não!'

\footnotetext{
${ }^{1}$ Uma das mais importantes figuras do simbolismo brasileiro, Luís Gonzaga Duque Estrada, foi romancista, contista e crítico de arte. Pode ser considerado o primeiro crítico de arte sistemático do Brasil, tendo deixado textos fundamentais nesse campo. Em 1910, foi nomeado diretor da Biblioteca Municipal do Rio de Janeiro.
} 
Era o capadócio ${ }^{2}$, uma das mais importantes entidades sociaes de então. O capadócio, que foi a origem do que hoje é capoeira ${ }^{3}$, vivia a bohemia, dormindo na casa de um amigo ou no posto da guarda, tocando viola nos fados, cobrindo as costas dos ricos nas occasiões de bordoada, resultante lógico de amores criminosos. Era, na maior parte, mestiço, rapagão alto, de cabelleira enorme e untada de banha de cheiro. Andava com o violão ou guitarra ao lado, como se fora uma bolsa de viagem. Em todos os fados elle entrava obrigatoriamente, por causa de cantar ao desafio, e tocar lundus, dedilhados em gementes arpejos de uma obscenidade revoltante! ${ }^{4}$

O violão era então utilizado essencialmente como acompanhador das serenatas e lundus.

Em 1808, o príncipe regente D. J oão VI (1767 - 1826) chegou ao Rio de Janeiro, foragido das invasões napoleônicas. Instalou sua corte e transformou a cidade em capital do reino de Portugal, cessando assim as funções do então vice-rei, Dom Marcos de Noronha e Brito (1771 - 1828). Quase oito anos mais tarde, em 1815, o Brasil era elevado da condição de Vice-Reino a Reino

\footnotetext{
2 In: HOUAISS, Antonio; VILLAR, Mauro de Salles. Dicionário Houaiss de Língua Portuguesa. Rio de Janeiro: Objetiva, 2001, p. 606, encontramos as seguintes definições para capadócio: Regionalismo Brasileiro. Pejorativo: que ou aquele que é pouco inteligente; ignorante; burro; que ou quem é impostor; trapaceiro, charlatão; que ou quem tenta enganar os outros se dando ares importantes; cabotino, espertalhão; que ou quem tem modos de canalha.

${ }^{3}$ In: HOUAISS, Antonio; VILLAR, Mauro de Salles. Op.cit., p. 613: Negro que vivia na capoeira (mato) e assaltava os viajantes. Por extensão do sentido: malandro típico do século XIX, no Rio de Janeiro, Bahia e Recife, lutador de rua que usava a capoeira (arte marcial), armado de navalha ou faca, para combater bandos rivais ou provocar desordens públicas.

${ }^{4}$ In: A VOZ DO VIOLÃO, Rio de Janeiro, 1931, n²1, p.4.
} 
integrado a Coroa de Portugal, formando-se assim o chamado Reino Unido de Portugal, Brasil e Algarves.

As condições para o nascimento da música urbana brasileira, a música dos chorões ${ }^{5}$, foram dadas pela chegada da corte portuguesa ao Brasil, fator que ocasionou um surto de desenvolvimento e modernização na cidade do Rio de Janeiro.

Investimentos para a criação de infra-estruturas de serviços públicos essenciais como correios e estradas de ferro, ao lado das leis anti-escravagistas, mudaram sensivelmente a feição social e econômica da cidade. A conseqüência foi o surgimento de um setor urbano, em sua maioria afro-brasileiro, que fornecerá não só a mão de obra para esta música, mas também seu público consumidor. O violão encontrará abrigo neste novo segmento social. I mpedido de freqüentar as classes mais abastadas que estavam atreladas aos modismos europeus, o violão passa a ter participação constante nas manifestações musicais que aconteciam nas classes menos privilegiadas.

Citamos a interessante síntese feita pelo pesquisador José Ramos Tinhorão no livro Os sons que vêm da rua:

Pelas descrições dos cronistas da vida popular carioca, principalmente, pode-se perceber que, atingido determinado momento do processo de

\footnotetext{
${ }^{5}$ Músicos populares do Rio de Janeiro do final do séc. XIX e começo do séc. XX. Oriundos normalmente da pequena classe média, eram contratados para tocar em festas, usando gêneros de dança vindos da Europa que, pouco a pouco, adaptaram à atmosfera local. In: DICIONÁRIO GROVE DE MÚSICA: Edição Concisa. Rio de Janeiro: Jorge Zahar, 1994, p.194.
} 
diversificação social, é o próprio mecanismo da vida urbana que gera os tipos de artistas de que necessita para entretenimento das camadas sem acesso aos quadros comuns do aproveitamento do lazer (...) O povo miúdo das cidades forma espontaneamente os seus artistas, e ainda eventualmente permite que alguns deles estendam o conhecimento dos seus talentos e habilidades a outras classes, através de exibições nas ruas, praças $(\ldots)^{6}$.

\section{Síntese que foi bem ilustrada pela seguinte desenho de Spix e}

\section{Martius, que figura no livro Viagens pelo Brasil ${ }^{7}$ :}

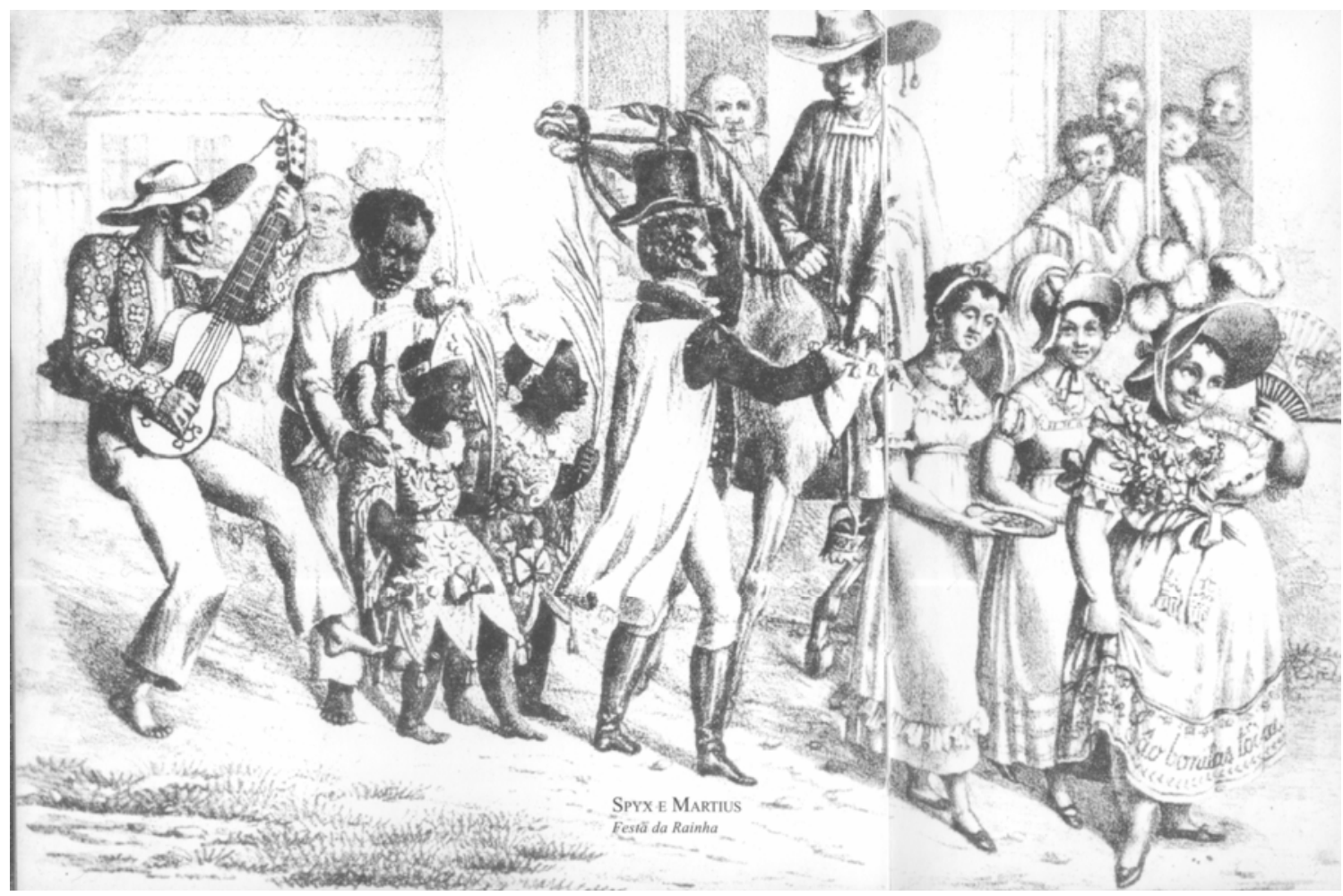

Figura 1. Representação da Festa da Rainha, em Viagens pelo Brasil, por Spix e Martius.

\footnotetext{
${ }^{6}$ TINHORÃO, José Ramos. Os sons que vêm da rua. 2. ed. São Paulo: Editora 34, 2005, p. 34.

${ }^{7}$ Os naturalistas Johann Baptiste von Spix (1781 - 1823) e Carl Friedrich Phillipp von Martius (1794 1868) chegaram ao Brasil na segunda década do século XIX. A expedição pelo país foi uma conseqüência indireta do contrato de casamento da arquiduquesa da Áustria, Dona Leopoldina, com D. Pedro de Alcântara, herdeiro da coroa portuguesa e primeiro imperador do Brasil. A expedição contava com uma completa comitiva de estudiosos das mais variadas ciências naturais. A viagem durou três anos e gerou o livro Viagens pelo Brasil, editado a primeira vez na Alemanha, em três volumes, nos anos de 1823, 1828 e 1831. Foi publicado incompleto no Brasil pela primeira vez em 1916 e em edição completa somente em 1938.
} 
Desde o tempo dos Vice-Reis, atravessando o século XIX, até chegar à República (1889) o violão foi marginalizado socialmente. Se durante o Primeiro e Segundo Reinados o instrumento era tolerado como acompanhante das modinhas trazidas de Portugal, na República o violão será expurgado para que o passado colonial seja esquecido. Sendo o Rio de Janeiro, a partir de 1889, a capital da República Federativa do Brasil, a remodelação da cidade traria intrínseca a idéia não só de progresso como também de nação. A face urbana da cidade foi remodelada, foram feitas reformas arquitetônicas no centro, ao mesmo tempo em que se excluíam dali as manifestações identificadas com as classes populares. Era preciso negar tudo que lembrasse o atraso colonial. Ao lado da capoeira, das rinhas de galo, do candomblé, coibiram-se, no centro da capital, também as rodas de música, local onde o violão tinha presença garantida nos acompanhamentos das serenatas, lundus e modinhas. O violão foi assim mais uma vez posto à margem desta sociedade que caminhava para o cosmopolitismo do início do século XX.

Nas duas primeiras décadas do século XX, o país viveu um momento de transformações sociais, econômicas e políticas, em que o mercado e a economia sofreram grande expansão ocasionada pela I Guerra Mundial. Se a Europa vivia as incertezas da Primeira Grande Guerra, no Rio de Janeiro a atmosfera era de inclusão compulsória e desenfreada na modernidade. 
Transcrevemos trecho de artigo de Saulo Wanderley ${ }^{8}$ que elucida as divisões sociais da música na então capital brasileira:

Botafogo, Copacabana, Gávea eram da classe A, que apreciava a Ópera Italiana. São Cristóvão e Vila Isabel eram da classe B, que gostava de modinhas pitorescas. Cidade Nova, Gamboa e Saúde eram da classe $C$, com suas modinhas dorde-cotovelo. A diferença entre as classes $\mathrm{B}$ e $\mathrm{C}$, ambas apreciadoras das modinhas, foi uma questão sexual... As letras que falavam de amor, casos e paixões eram coisas do violão bandido, expurgado para uma classe $C$, enquanto a classe $B$ preferia pensar que era assexuada e curtia as modinhas de 'temas pitorescos'. O libidinoso ritmo do Maxixe (cujo nome vem de uma planta vagabunda, que crescia em qualquer lugar) atacava os salões. A imprensa publicava artigos contra o violão e até 'charges' com a diferença entre a tradicional forma de tirar uma dama para dançar antigamente e nos dias de então serviam para atacar o Maxixe. O desenho de 'cavalheiros' tomando a dama pela mão e dançando a uma 'distância cortês' se confrontavam com as do 'cafajeste' chamando a dama para dançar por assobio ${ }^{9}$.

\footnotetext{
${ }^{8}$ Saulo Wanderley é músico, formado pela Unicamp, jornalista e membro fundador do Núcleo de Música Nova de São Paulo.

${ }^{9}$ WANDERLEY, Saulo. O dia em que o violão deixou de ser bandido. [s.I.], 1998. Disponível em:

<http://www.cafemusic.com. br>. Acesso em 12, maio 2005.
} 
Seguem duas charges do caricaturista Calixto Cordeiro (1877 1957), ou Kalixto, a primeira intitulada Maxixe e a segunda Polca, que ilustram o parágrafo acima:

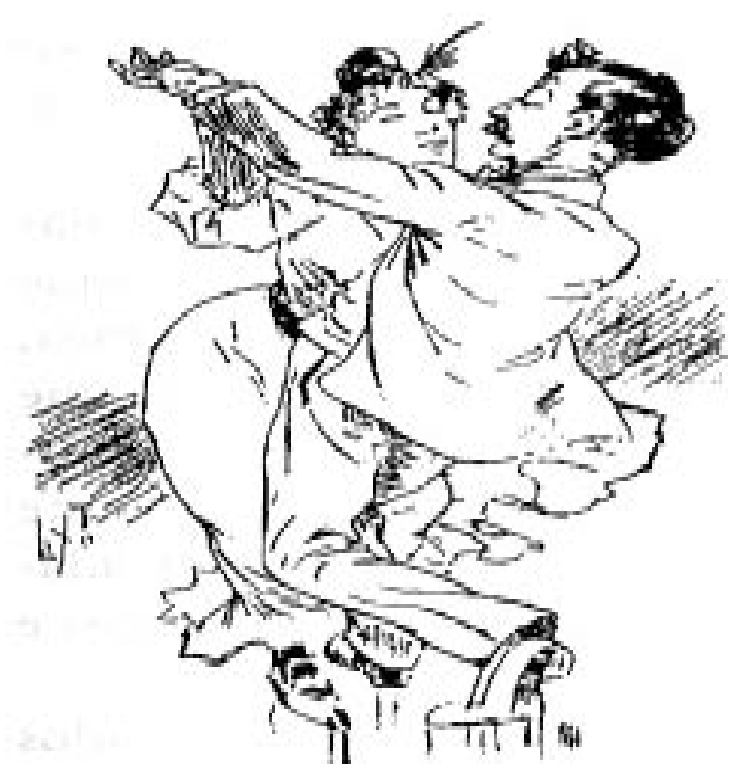

Figura 2. Representação da dança maxixe, por Kalixto.

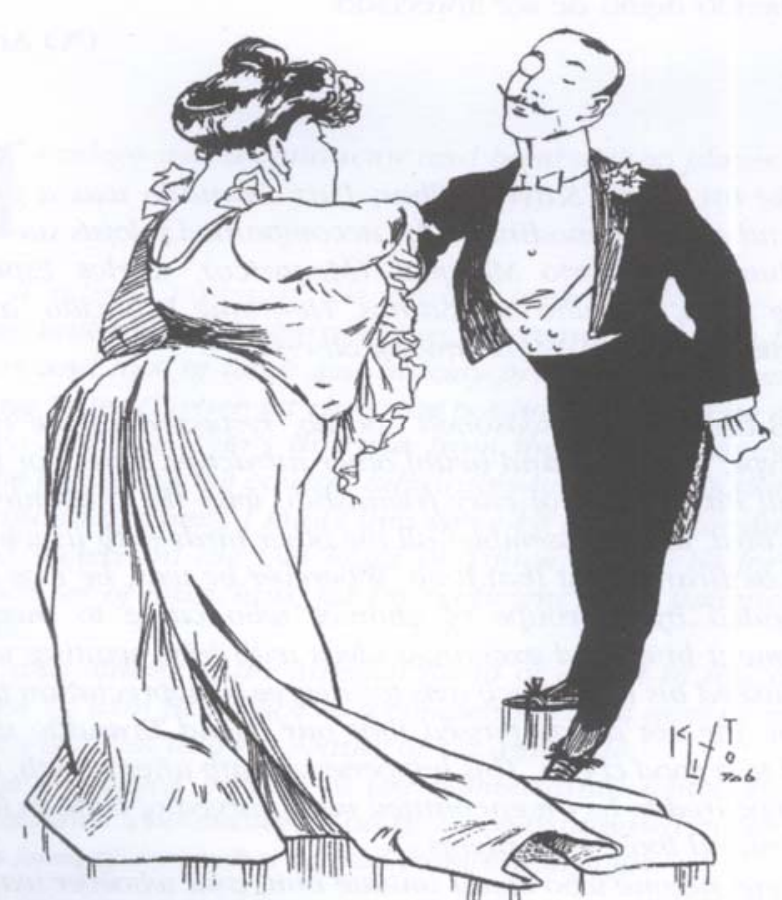

Figura 3. Representação da dança Polca, por Kalixto. 
No primeiro exemplar da revista O Violão (1929), a coluna O Violão entre nós, ilustra a reputação do instrumento no Brasil:

Infelizmente, porem, somente há pouco tempo teve o violão o ingresso nas altas camadas sociaes, não porque estas o desprezassem, mas por ter elle sido sempre aviltado e achincalhado pelos maiores de antanho.

Era o companheiro inseparável do seresteiro (o violão), synonimo ameno encontrado para vagabundo e desordeiro, e quem o cultivasse, nelle teria a peor das recommendações. Prova isso a informação dada pelo célebre oficial Aragão a um juiz, sobre determinado preso. Diz ele no documento:

‘...E sirva-se V.Ex. de mandar examinar os dedos da sua (delle) mão esquerda que verificará a verdade affirmada por esta policia, isto é, trata-se de um serenatista inveterado a que se chama também vulgarmente seresteiro'.

É que em nosso paiz o Violão, não tendo tido entrada na corte e altas casas sociaes, foi encontrar na plebe a guarida necessária ${ }^{10}$.

No clássico pré-modernista Triste Fim de Policarpo Quaresma, publicado em folhetim em 1911, o escritor Lima Barreto (1881-1922) mostra o preconceito contra o violão na virada do século XIX para o XX. Já há, no entanto, a tímida aproximação de uma classe mais privilegiada ao universo das modinhas e do violão, representada na

${ }^{10}$ O VIOLÃO. Rio de Janeiro, 1928, no. 1, p. 8. 
figura do protagonista do romance, o Major Policarpo Quaresma.

Transcrevemos abaixo um trecho do primeiro capítulo denominado A Lição de Violão:

(...) Eram esses os seus hábitos; ultimamente, porém, mudara um pouco; e isso provocava comentários no bairro. Além do compadre e da filha, as únicas pessoas que o visitavam até então, nos últimos dias, era visto entrar em sua casa, três vezes por semana e em dias certos, um senhor baixo, magro, pálido, com um violão agasalhado numa bolsa de camurça. Logo pela primeira vez o caso intrigou a vizinhança. Um violão em casa tão respeitável! Que seria? $E$, na mesma tarde, uma das mais lindas vizinhas do major convidou uma amiga, e ambas levaram um tempo perdido, de cá para lá, apalmilhar o passeio, esticando a cabeça, quando passavam diante da janela aberta do esquisito subsecretário. Não foi inútil a espionagem. Sentado no sofá, tendo ao lado o tal sujeito, empunhando o 'pinho' na posição de tocar, o major, atentamente, ouvia: 'Olhe, major, assim'. E as cordas vibravam vagarosamente a nota ferida; em seguida, o mestre aduzia: 'É 'ré', aprendeu?' Mas não foi preciso pôr na carta; a vizinhança concluiu logo que o major aprendia a tocar violão. Mas que coisa? Um homem tão sério metido nessas malandragens!

Uma tarde de sol - sol de março, forte e implacável - aí pelas cercanias das quatro horas, as janelas de uma erma rua de São Januário povoaram-se rápida e repentinamente, de um e de outro lado. Até da casa do general vieram 
moças à janela! Que era? Um batalhão? Um incêndio? Nada disto: o Major Quaresma, de cabeça baixa, com pequenos passos de boi de carro, subia a rua, tendo debaixo do braço um violão impudico.

É verdade que a guitarra vinha decentemente embrulhada em papel, mas o vestuário não Ihe escondia inteiramente as formas. À vista de tão escandaloso fato, a consideração e o respeito que o Major Policarpo Quaresma merecia nos arredores de sua casa diminuíram um pouco. Estava perdido, maluco, diziam. Ele, porém, continuou serenamente nos seus estudos, mesmo porque não percebeu essa diminuição.

(...) Quando entrou em casa, naquele dia, foi a irmã quem Ihe abriu a porta, perguntando:

- Janta já?

- Ainda não. Espere um pouco o Ricardo ${ }^{11}$ que vem jantar hoje conosco.

- Policarpo, você precisa tomar juízo. Um homem de idade, com posição, respeitável, como você é, andar metido com esse seresteiro, um quase capadócio - não é bonito!

No mesmo ano de 1911 , João do Rio ${ }^{12}$ (1881 - 1921), publica o livro Vida Vertiginosa, onde encontramos na crônica Os livres acampamentos da miséria uma radiografia da sociedade da época com certas áreas de intersecção já sendo começando a ser delineadas:

\footnotetext{
${ }^{11}$ Ricardo Coração dos Outros, professor de violão do citado romance, ver capítulo 2, em Catulo da Paixão Cearense, p. 42.

12 J oão do Rio, pseudônimo de Paulo Barreto, cronista, teatrólogo e contista. Notabilizou-se como o primeiro homem de imprensa brasileira a possuir o senso de reportagem de crônica social moderna. Sua estréia no jornalismo se deu no jornal Cidade do Rio (1899). Fundou o Rio Jornal, A Pátria (1926) e a revista Atlântica (1915). Colaborou também em outros periódicos do Rio de Janeiro, São Paulo e Portugal. Foi fundador e primeiro diretor da Sociedade Brasileira de Autores Teatrais (1917). Aos 29 anos entrou para a Academia Brasileira de Letras.
} 
Certo já ouvira falar das habitações do morro de Santo Antonio, quando encontrei, depois da meianoite, aquele grupo curioso - um soldado sem número no boné, três ou quatro mulatos que tocavam violão em punho. Como olhasse com insistência tal gente, os mulatos que tocavam de súbito emudeceram os pinhos (...) Era no largo da Carioca. Alguns elegantes nevralgicamente conquistadores passavam de ouvir uma companhia de operetas italianas e paravam a ver os malandros que me olhavam e eu que olhava os malandros num evidente início de escandalosa simpatia. Acerquei-me.

- Vocês vão fazer uma serenata?

- Sim, senhor.

- Mas aqui no largo?

- Aqui foi só para comprar um pouco de pão e queijo. Nós moramos lá em cima, no morro de Santo Antonio...

Eu tinha do morro de Santo Antonio a idéia de um lugar onde pobres operários se aglomeravam a espera de habitações, a tentação veio de acompanhar a 'seresta' morro acima. Dei o necessário para a ceia em perspectiva e declarei-me preso ao violão. Graças aos céus não houve admiração. Muita gente, no dizer do grupo, pensava do mesmo modo, indo visitar os seresteiros no alto da montanha. (grifo nosso) ${ }^{13}$.

No artigo: 1916, O violão brasileiro já é uma arte, importante trabalho de exaustiva pesquisa em jornais da época, realizado por

${ }^{13}$ RIO, João do. [Paulo Barreto]. Uma antologia. 3. ed. Rio de Janeiro: José Olympio, 2005, p. 51. 
Paulo Castagna e Gilson Antunes ${ }^{14}$, temos, através da imprensa escrita, um panorama da mentalidade do período acerca do instrumento.

Na referida pesquisa, os autores destacam, em maio de 1916, um trecho do Jornal do Comércio, Rio de Janeiro:
Debalde os cultivadores desse instrumento procuram fazê-lo ascender aos círculos onde a arte paira. Tem sido um esforço vão o que se desenvolve nesse sentido. O violão não tem ido além de simples acompanhador de modinhas. E quando algum virtuoso quer tirar efeitos mais elevados na arte dos sons, jamais consegue o objetivo desejado ou mesmo resultado apreciável. A arte, no violão, não passa, por isso, até agora, do seu aspecto puramente pitoresco ${ }^{15}$.

Poucas semanas depois, no mesmo periódico, uma comparação com a guitarra portuguesa:
A guitarra nasceu para o fado e o violão para a modinha. Violão e guitarra são instrumentos populares, cujas cordas palpitam tristezas, lágrimas e risos de dois povos intimamente ligados pela afinidade de raça, de coração e de língua. Acompanhando uma canção sentimental ou dedilhando um fado corrido, a guitarra e o violão falam não só à alma de popular, mas à alma de

\footnotetext{
${ }^{14}$ Gilson Antunes é violonista, pesquisador e professor da Universidade Federal da Paraíba. Realizou uma dissertação de mestrado (ECA-USP, 2000) sobre o violonista Américo Jacomino. Paulo Castagna é pesquisador e professor Doutor do Instituto de Artes da Universidade Estadual Paulista (UNESP).

${ }^{15}$ Apud. ANTUNES, Gilson; CASTAGNA, Paulo. 1916: O violão brasileiro já é uma arte. São Paulo: Cultural Vozes, 1994, p. 37-51.
} 
toda a gente. Uma e outro jamais lograrão alcançar a perfeição sonhada pelos seus cultores apaixonados. As regiões da música clássica não Ihe são propícias, as suas cordas não se dão muito bem nos ambientes de arte propriamente dita ${ }^{16}$.

O violonista e compositor Donga - Ernesto J oaquim Maria dos Santos (1890 - 1974), nos dá a dimensão do que aqueles que 'se envolvessem' com o violão estariam expostos:

Todos os pais daquela época não queriam o cidadão no choro, porque era feio, era crime previsto no Código Penal (...) O fulano (polícia) pegava o outro tocando violão, esse sujeito do violão estava perdido, perdido! Mas per-di-do, pior do que comunista. Muito pior. Isso é verdade o que estou Ihe contando, não era brincadeira não ${ }^{17}$.

Catulo da Paixão Cearense foi também vítima deste preconceito. Consta que "na noite em que Catulo apresentava em uma serenata, sua primeira produção, foi seguido por seu pai, que Ihe arrancando das mãos o violão, quebrou estrepitosamente o instrumento na cabeça do filho" ${ }^{18}$. Villa-Lobos amarrava seu violão no estrado da cama, para evitar acidentes como o que sucedera a Catulo da Paixão Cearense ${ }^{19}$.

\footnotetext{
${ }^{16}$ Apud. ANTUNES, Gilson; CASTAGNA, Paulo. Op. Cit., p.38.

${ }^{17}$ CARVALHO, Hermínio Bello de. Mudando de Conversa, p. 36.

${ }^{18}$ VASCONCELOS, Ary. Panorama da Música Popular Brasileira na Belle Epoque, p.116.

19 PRESENÇA DE VILLA-LOBOS. 1. edição. Rio de Janeiro: MEC/Museu Villa-Lobos, vol.3, 1969, p. 139.
} 
Conforme vimos até aqui, o violão conquistou sua reputação no tempo dos capadócios e a carregaria das modinhas e lundus ao choro e samba percorrendo um longo caminho até ser reabilitado como instrumento sério. Para uma melhor compreensão desta trajetória e para que seja possível a inserção de nosso objeto de pesquisa neste panorama, vamos investigar mais a fundo os processos de criação e evolução do violão brasileiro. 


\section{Reabilitação do Violão Brasileiro ( 1914 - 1930)}

A aceitação do violão como instrumento de concerto no Brasil foi resultante da atuação de um grupo de pioneiros, da aproximação de intelectuais com acesso às classes mais privilegiadas, e, sobretudo, do aparecimento de uma nova técnica de execução e de um novo repertório, que transformaram completamente a receptividade do violão na sociedade brasileira.

O movimento modernista, ao rejeitar o piano, instrumento associado à tradição romântica elitista européia, acabou incorporando o violão ao universo simbólico de suas aspirações, como bem ilustra Cambraia Naves, no livro Violão Azul, Música Popular e Modernismo:
À recusa do piano sucede-se, portanto a incorporação do violão, o que ilustra um outro aspecto da discussão modernista: a valorização das culturas populares e/ou primitivas. Nesse esforço modernista de aproximar o elevado (associado ao erudito) do baixo (popular), o violão ganha força simbólica como instrumento que possibilita a transição entre esses dois mundos ${ }^{1}$.

Dois marcos importantes para a reabilitação do instrumento: o ano de 1914 e o ano de 1916. Em 1914, a então primeira dama do país Nair de Tefé (1886 - 1981), esposa de Hermes da Fonseca (1855 - 1923), escandaliza a sociedade trazendo o violão para o Palácio do

\footnotetext{
${ }^{1}$ NAVES, Santuza Cambraia. O Violão Azul: Música Popular e Modernismo. Rio de Janeiro: Editora Fundação Getúlio Vargas, 1998, p.26.
} 
Catete, executando o Corta-Jaca de Chiquinha Gonzaga (1847 1835) e tendo como seus convidados para o referido sarau ${ }^{2}$ os violonistas Catulo da Paixão Cearense, Ernani de Figueiredo, Brant Horta e Quincas Laranjeiras. O violão passaria por um momento de notoriedade, tornando-se uma verdadeira febre entre as damas da sociedade da capital. No Diccionario de Guitarras, Guitarristas y Guitarreros, de Domingo Prat (1886 - 1944), em verbete sobre o violonista Melchior Cortez (1882 - ?), encontramos:

El professor Melchior Cortez es bastante conocido em Rio, principalmente em la alta sociedade, a que pertence su actual cuerpo de alunas (...) que se encantaran oyendo preludiar a aquella excelentissima dama amateur de guitarra, Nair Tefé, esposa del que fué Presidente de la republica, mariscal Hermes da Fonseca ${ }^{3}$.

Alguns setores mais conservadores da imprensa, contudo, registraram críticas e comentários desfavoráveis:

\section{Nair de Tefé escandaliza políticos com recital no palácio do Catete}

Águia de Haia não poupa nem as damas. $\mathrm{Na}$ sessão do senado do dia 11 de novembro de 1914, Rui Barbosa teceu ferozes críticas à esposa do presidente, Nair de Tefé. Nair de Tefé executou o Corta Jaca, um maxixe composto por Chiquinha

\footnotetext{
${ }^{2}$ Ver detalhes sobre sarau em Catulo da Paixão, p. 42.

3 PRAT, Domingo. Diccionario de Guitarras, Guitarrista y Guitarreros., 1. ed. Buenos Aires: Romero Y Fernández, 1934, p. 91.
} 
Gonzaga ${ }^{4}$. $\mathrm{O}$ acontecimento serviu de motivo para que, já no dia seguinte, não faltassem críticas ao governo e aos escândalos no palácio, que promovia a adoção pela sociedade de músicas cujas origens estavam nas danças lascivas e cânticos dos escravos ${ }^{5}$.

\section{Rui Barbosa (1849 - 1923) acusou quebra de protocolo,} pronunciando-se:

(...) diante do Corpo Diplomático, e da mais fina sociedade do Rio de Janeiro, aqueles que deviam ao País o exemplo das maneiras as mais distintas e dos costumes mais reservados, elevaram o Corta Jaca à altura de uma instituição social. Mas o Corta Jaca de que eu ouvira falar a muito tempo, que vem a ser ele, Sr. Presidente? É a mais baixa, mais chula, a mais grosseira de todas as danças selvagens, irmã gêmea do batuque, do cateretê e do samba. Mas nas recepções presidenciais o Corta Jaca é executado com todas as honras de música de Wagner, e não se quer que a consciência deste País se revolte, que as moças se enrubesçam e que a mocidade se ria! ${ }^{6}$.

A partir de 1916 nos deparamos com dois personagens principais que vão influenciar a trajetória do instrumento no país: Agustin Barrios (1885-1944) e Josefina Robledo (1892-1972).

\footnotetext{
${ }^{4}$ Em uma das fontes bibliográficas deste trabalho, o livro O Violão Azul, de autoria de Santuza Cambraia Naves, foi-nos possível notar um lapso da autora. Na p.29, encontramos a informação: (...) Promovendo uma apresentação musical de Chiquinha Gonzaga no Palácio do Catete. A compositora executou ao violão o tango Corta-Jaca, o que provocou reações bastante negativas na cidade, como a de Rui Barbosa (...). Em realidade Chiquinha Gonzaga não esteve presente a esta apresentação musical e não temos notícias de um encontro entre Nair de Teffé e a compositora do Corta-Jaca.

${ }^{5}$ BIBLIOTECA VIRTUAL OSWALDO CRUZ. O Rio de Janeiro de seu tempo. Disponível em:

<http://www2. prossiga.br/ocruz/principal.htm>. Acesso em 20, Ago. 2006.

${ }^{6}$ MUGNAINI, Ayrton J r. A J ovem Chiquinha Gonzaga. São Paulo: Editora Nova Alexandria, 2005, p. 114.
} 
As primeiras apresentações do paraguaio Agustin Barrios, em 1916, e da espanhola Josefina Robledo, em 1917, provocaram um enorme impacto no público, nos músicos e na imprensa.

Após o primeiro recital de Agustín Barrios, no Rio de Janeiro, em 24 de julho de 1916, o mesmo Jornal do Comércio que, como vimos anteriormente havia censurado o violão como instrumento sério, agora dirige sua crítica aos executantes brasileiros:

Sem querer dar ao violão a hierarquia aristocrática do violino, do violoncelo e de outros instrumentos que, como ele, tiveram no alaúde o seu remoto ancestral, em todo caso acreditamos que não se faz ainda ao violão a justiça que lhe é devida - o que, até certo ponto, se explica pela dificuldade da técnica do instrumento que ninguém, quase, tenta vencer e dominar, desanimados todos pela igualdade do timbre que Ihe dá uma feição de monotonia.

Não compreendemos, porém, que se cultive o bandolim em prejuízo do violão, quando a superioridade deste é imensa como elemento de expressão, como variedade de efeitos, como exemplar de harmonização interessante na formação dos acordes, como recurso de modulações estranhas pela sua novidade. De ordinário, os cultores do violão limitam-se a fazer dele um instrumento de acompanhamento de modinhas chorosas, ou o monótono repetidor de desenhos rítmicos de dança, ou o intérprete dos rasgados sonorosos que convidam ao sapateado languoroso e lascivo! Quanta injustiça! Essa mediocridade, a que condenaram o violão, tem a 
sua explicação na ignorância dos que lhe ponteiam as cordas sem o conhecimento da riqueza de efeitos que se podem obter do precioso instrumento, que mereceu particular atenção de Berlioz no seu tratado de instrumentação (...) Como já fizemos sentir, o violão sofre principalmente pelas dificuldades que ele oferece e que poucos ousam afrontar pelo estudo. Só nestes últimos tempos é que por aqui tem aparecido alguns cultores como os Srs. Ernani de Figueiredo, Brant Horta e alguns raros mais ${ }^{7}$.

Dada à importância das figuras de J osefina Robledo e Agustín Barrios para a evolução do instrumento no país, inserimos aqui seus conteúdos biográficos para uma melhor compreensão da trajetória do violão no país. Catulo da Paixão Cearense, embora não fosse propriamente um violonista, foi figura central na reabilitação do instrumento, como veremos.

Para que possamos analisar mais profundamente a reabilitação do violão brasileiro, foram necessárias também inserções de algumas informações sobre os principais violonistas. Este procedimento nos ajudará a situar a obra de Othon Salleiro na história do instrumento, uma vez que a obra destes violonistas irá nos auxiliar na definição de parâmetros para a compreensão do estilo de composição e da idiomática instrumental de nosso objeto de pesquisa.

\footnotetext{
${ }^{7}$ Apud. ANTUNES, Gilson; CASTAGNA, Paulo. Op. cit, p. 35.
} 
Agustín Barrios ( 1885 - 1944) - Legendário compositor e violonista paraguaio, Agustín Pio Barrios, cresceu, segundo Prat, em seu já citado Diccionario: “En médio de un ambiente musico guitarristico bien precario, por no decir nulo" ${ }^{8}$. Teve aulas com o professor Gustavo Sosa Escalada, violonista tido como fundador da escola paraguaia de violão, e que introduziu Barrios no instrumento através das obras de Fernando Sor, Dionísio Aguado e Francisco Tárrega.

Agustín Barrios foi um dos primeiros violonistas da história da música a realizar gravações (1910-1913), através da nova tecnologia dos gramofones.

Extraordinário instrumentista, conforme mostram seus registros, inventivo compositor e músico andarilho, poderíamos dizer que sua vida foi uma grande turnê pelas cidades de países como Paraguai, Argentina, Chile, Venezuela, Trinidad, Republica Dominicana, Haiti, Guatemala, Cuba, México, Uruguai, Brasil e El Salvador, onde, no fim de sua vida, estabeleceu-se em 1940, como professor de violão no Conservatório Nacional de El Salvador. Na Europa apresentou-se na Bélgica, Alemanha e Espanha.

No Brasil, passou duas temporadas. A primeira, em 1916, ficando durante seis anos. Alcançou rápido sucesso entre nós. Mesmo com uma agenda de concertos agitada, fez ainda, neste período, visitas a Buenos Aires, onde presumivelmente dava continuidade às suas gravações. Depois de uma volta decepcionante ao Paraguai, 
retornou ao Brasil e percorreu o país de norte a sul, visitando os vinte e um estados brasileiros até $1932{ }^{9}$.

Arthur Napoleão (1843 - 1925), compositor e pianista, ao ouvir Agustín Barrios executar sua Romanza, transcrição feita pelo violonista, escreveu-Ihe esta dedicatória:

\author{
Para Don Agustín Barrios: \\ Sua adaptação para violão da minha Romanza é \\ um encantamento, e sua interpretação é outro! \\ Nada mais que eu possa dizer. \\ Arturo Napoleão
}

Rio, J unho de $1919{ }^{10}$.

Ainda em 1919, Barrios foi convidado pelo então presidente do Brasil, Epitácio Pessoa (1865 - 1942) para realizar um concerto no palácio presidencial. A platéia era formada por diplomatas e ministros.

Deixou fortes impressões também nos meios intelectuais, foi reverenciado por Olavo Bilac (1865 - 1918), Manuel Bandeira e Coelho Neto (1864-1934). Este último deixou o curioso depoimento reproduzido abaixo:

\footnotetext{
${ }^{9}$ TUCKER, Robert. The Legacy of Agustin Barrios. In: BARRIOS, Agustin. The Complete Guitar Recordings 1913-1942. Heidelberg: Chanterelle Historical Recordings, 1993. 3 CD, digital, estéreo.

${ }^{10}$ STOVER, Richard. The Life and Times of Agustín Barrios Mangoré. 1 ed.California: Querico Publications, 1992, p. 54. Original em inglês: To Don Agustin Barrios: Your adaptation for guitar of my Romanza is an enchantment, and your playing another! Nothing more can I say. Arturo Napoleão. Rio, June 1919.

Curiosamente, a Casa Arthur Napoleão editou esta obra com transcrição do violonista I saias Savio (1900 -1977).
} 
Quando Agustin Barrios encostou ao peito o pérfido instrumento, como se nele quisesse fazer passar o coração, esperei as vozes condenadas, os sons lascivos das serenatas, as melodias lânguidas que inebriavam as vítimas de todos estes desnaturados demolidores da honra. Mas as cordas vibravam suaves e eu tive como a revelação de uma nova harmonia...sob os dedos prodigiosos desse admirável artista, que é o maior que, no seu gênero, tenho visto, o violão vive e diz toda a sua história ${ }^{11}$.

Já o poeta Manuel Bandeira (1886 - 1968) escreveu o seguinte texto:

(...) Ele (o violão) foi, porém, reabilitado pela visita que recebemos de dois estrangeiros, os quais vieram revelar aos nossos amadores todos os recursos e a verdadeira escola dos grandes virtuoses de Espanha. Refiro-me a Agostinho Barrios e Josefina Robledo. O primeiro era paraguaio e tinha um jogo mais brilhante, mais pessoal. Era um rebelde, um revolucionário. Embora conhecesse perfeitamente a escola de Aguado (aprendera com um discípulo de Garcia-Tolsa), passava por cima dela muitas vezes. O emprego das cordas de aço, alias, modificando um pouco o timbre do instrumento, exigia uma técnica especial. A de Barrios baseavase no máximo aproveitamento possível da terceira corda, cujas vozes são mais cheias e pastosas. Todavia Barrios tocava com igual habilidade e encanto no encordoamento de tripa, como tive ocasião de verificar. Barrios compunha também.

${ }^{11}$ BARBOSA, Artur Luiz; Leal, José de Souza. Op. Cit, p. 27. 
Eram próprias a maior parte das peças que executava. Infelizmente nenhuma das suas produções está impressa ${ }^{12}$.

No Rio de Janeiro, mais precisamente na loja Ao Cavaquinho de Ouro ${ }^{13}$, Barrios conviveu e influenciou músicos populares como J oão Pernambuco, Villa-Lobos, Catulo da Paixão Cearense, Levino da Conceição, Quincas Laranjeiras e Othon Salleiro, sendo este último o violonista brasileiro que sofreu maior influência do compositor de La Catedral.

Lembramos que Barrios compôs Maxixe e Choro da Saudade, músicas claramente influenciadas pelo contato com os músicos brasileiros. Teria composto Choro da Saudade após ouvir J oão Pernambuco tocar um jongo ${ }^{14}$ na loja Ao Cavaquinho de Ouro. O violonista paraguaio registrou duas vezes a Tarantela, em 1921 e 1928 respectivamente, música de Levino da Conceição, outro importante violonista brasileiro da época, como veremos adiante.

Assim como na obra de Othon Salleiro, encontramos na música de Barrios diversas abordagens estilísticas, como a extensão dos processos tarreguianos, onde a exploração da tradição clássicoromântica se insere e o olhar para as tradições populares da América do Sul e Central, incluindo a música folclórica e urbana da Argentina, Chile, Uruguai, Paraguai, Brasil e Costa Rica.

\footnotetext{
${ }^{12}$ BANDEIRA, Manoel. A Literatura do Violão. Artigo originalmente publicado na revista Ariel, n. $13,1924$. Reaparece na Revista de Música Popular, editada por Lúcio Rangel (1914 - 1979), n. 8, 1956. O conteúdo deste artigo nos faz crer que o autor de Estrela da Vida Inteira tivesse conhecimento apurado da técnica violonística.

${ }^{13}$ Loja de instrumentos musicais, situada à Rua da Carioca, 44, centro do Rio de Janeiro. Ponto de encontro entre os músicos onde os chorões exibiam suas recentes composições.

14 BARBOSA, Artur Luiz; Leal, José de Souza. João Pernambuco: Arte de um povo. Rio de Janeiro: FUNARTE, 1982, P. 27.
} 
Seguem abaixo dois pequenos exemplos da música de Barrios explorando o universo da música brasileira:
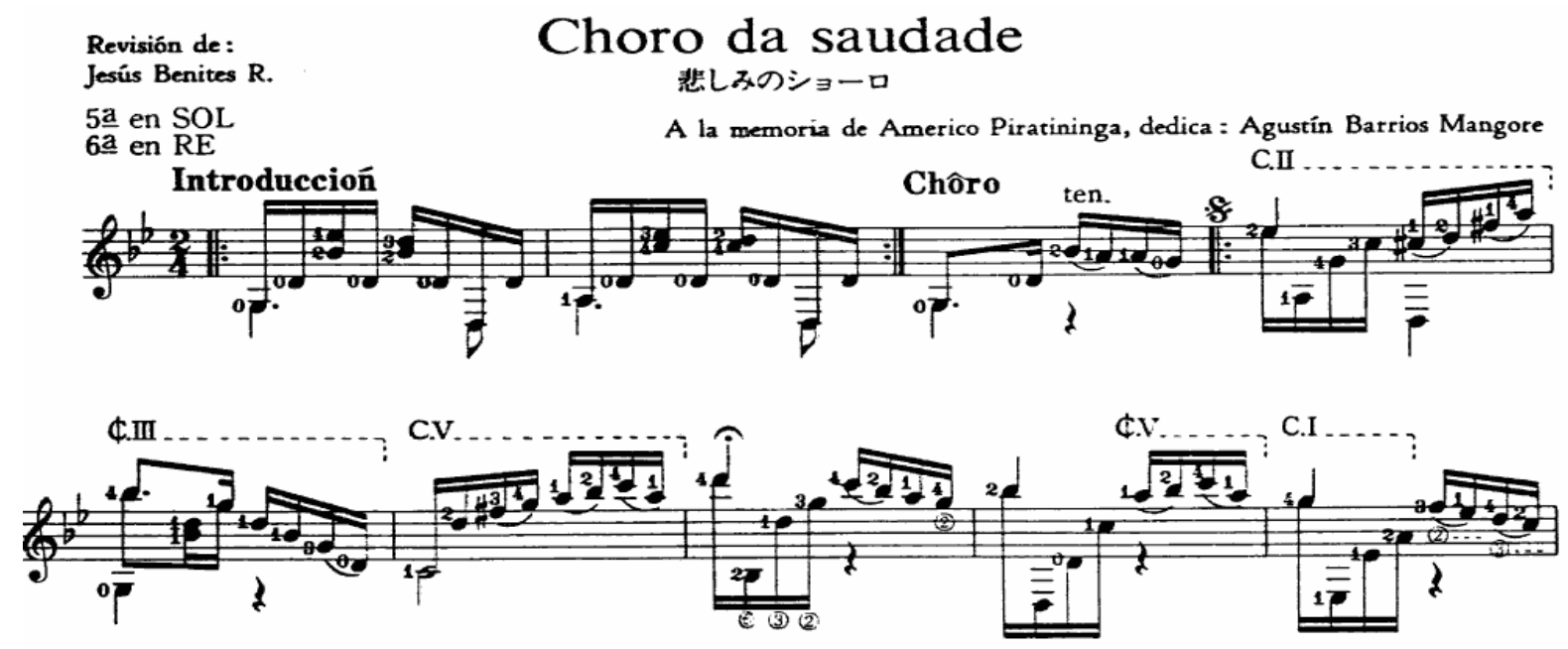

Extrato de Partitura 1. Choro da Saudade de Agustín Barrios.

\section{Maxixe}

Revisión de:

Jesús Benites $R$.

$$
\begin{gathered}
\text { マヒーヘ } \\
\text { (マヒーシャ・ガラー钵) }
\end{gathered}
$$
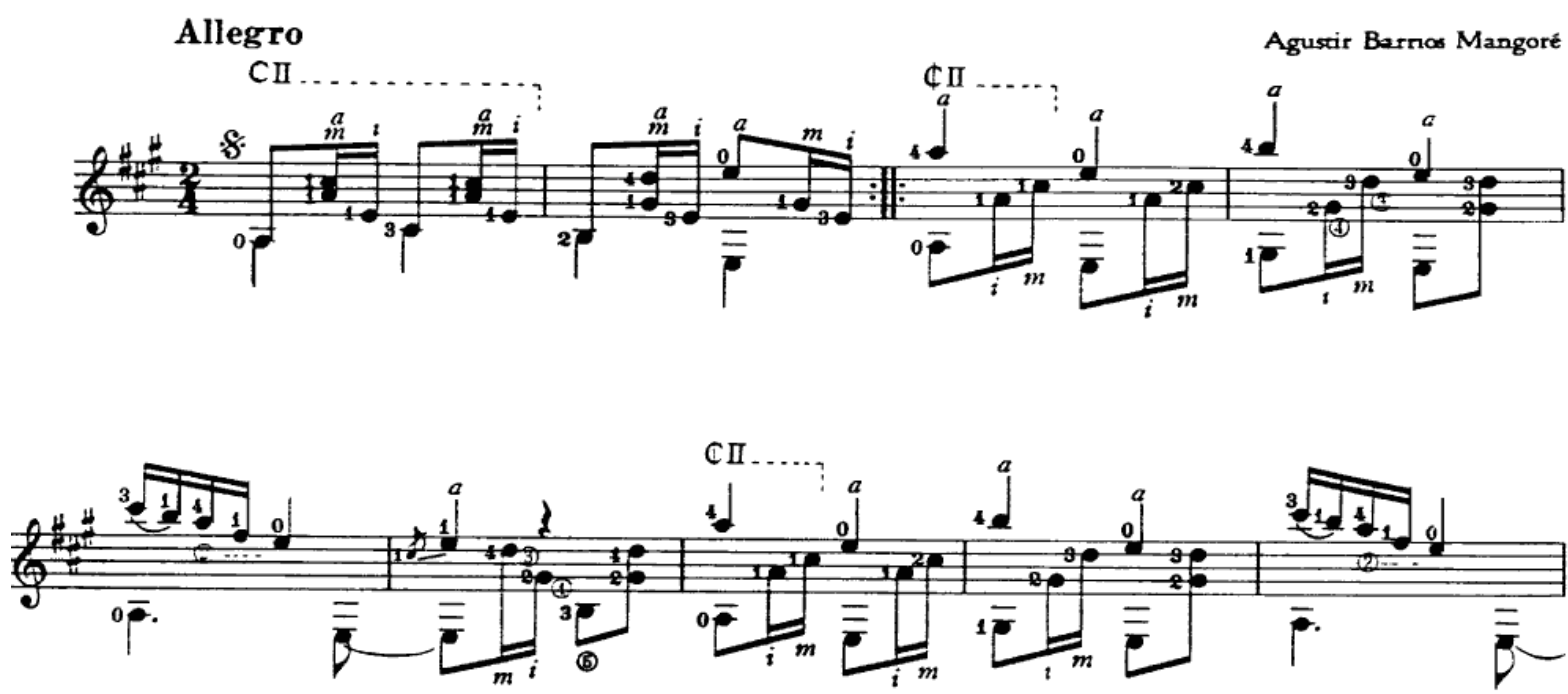

Extrato de Partitura 2. Maxixe, de Agustín Barrios. 


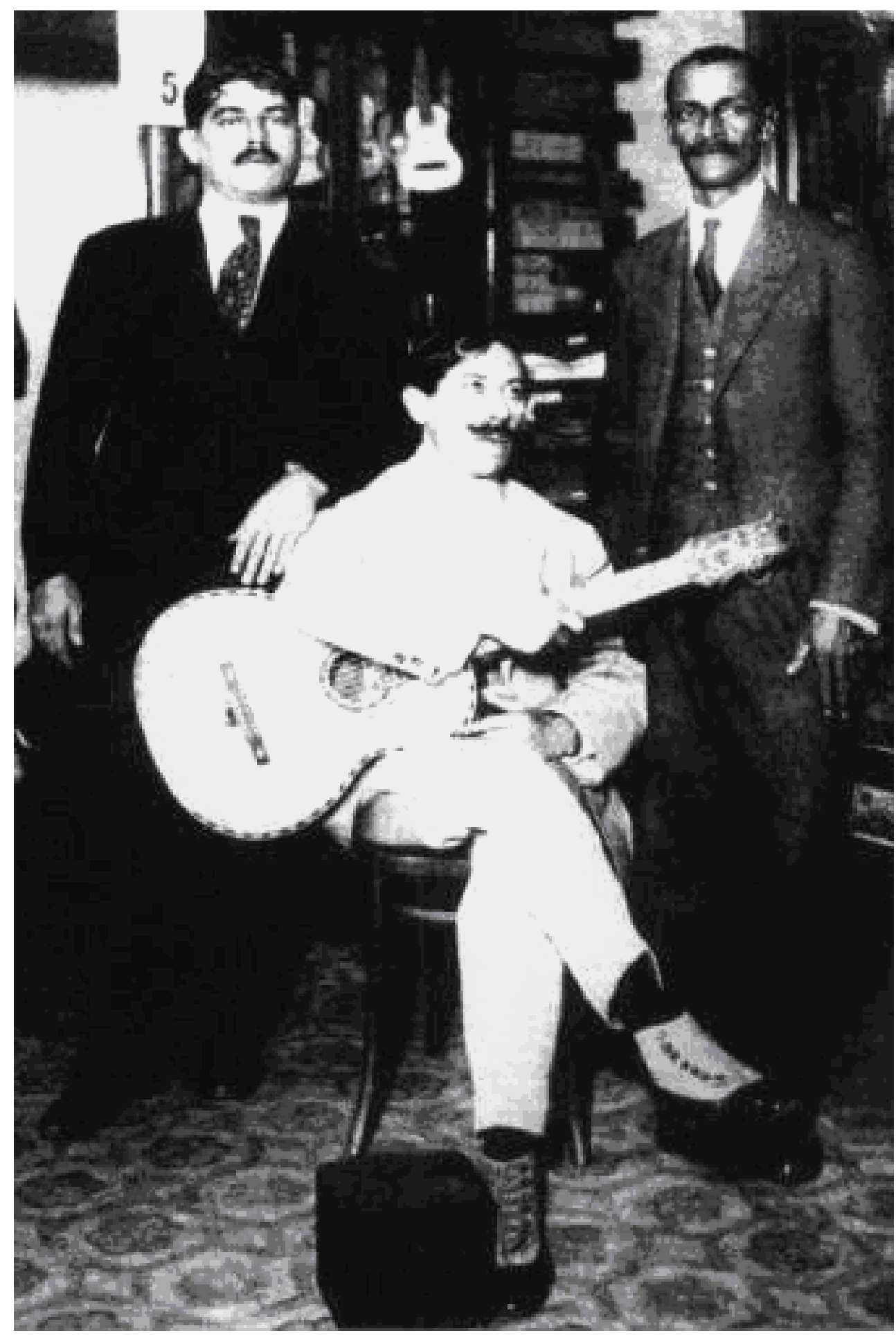

Figura 4. João Pernambuco, Agustín Barrios e Quincas Laranjeiras,

no ponto de encontro dos músicos, a Loja Ao Cavaquinho de Ouro. Rio de Janeiro, 1929. 
J osefina Robledo (1892-1972) foi discípula de Francisco

Tarrega ${ }^{15}$. Em 1914 começaram as turnês pela Argentina, Uruguai,

Paraguai e Brasil. Fixou residência na América do Sul por uma década,

primeiro na Argentina e depois no Brasil, na capital e posteriormente

em São Paulo, onde se dedicou a lecionar e divulgar o instrumento.

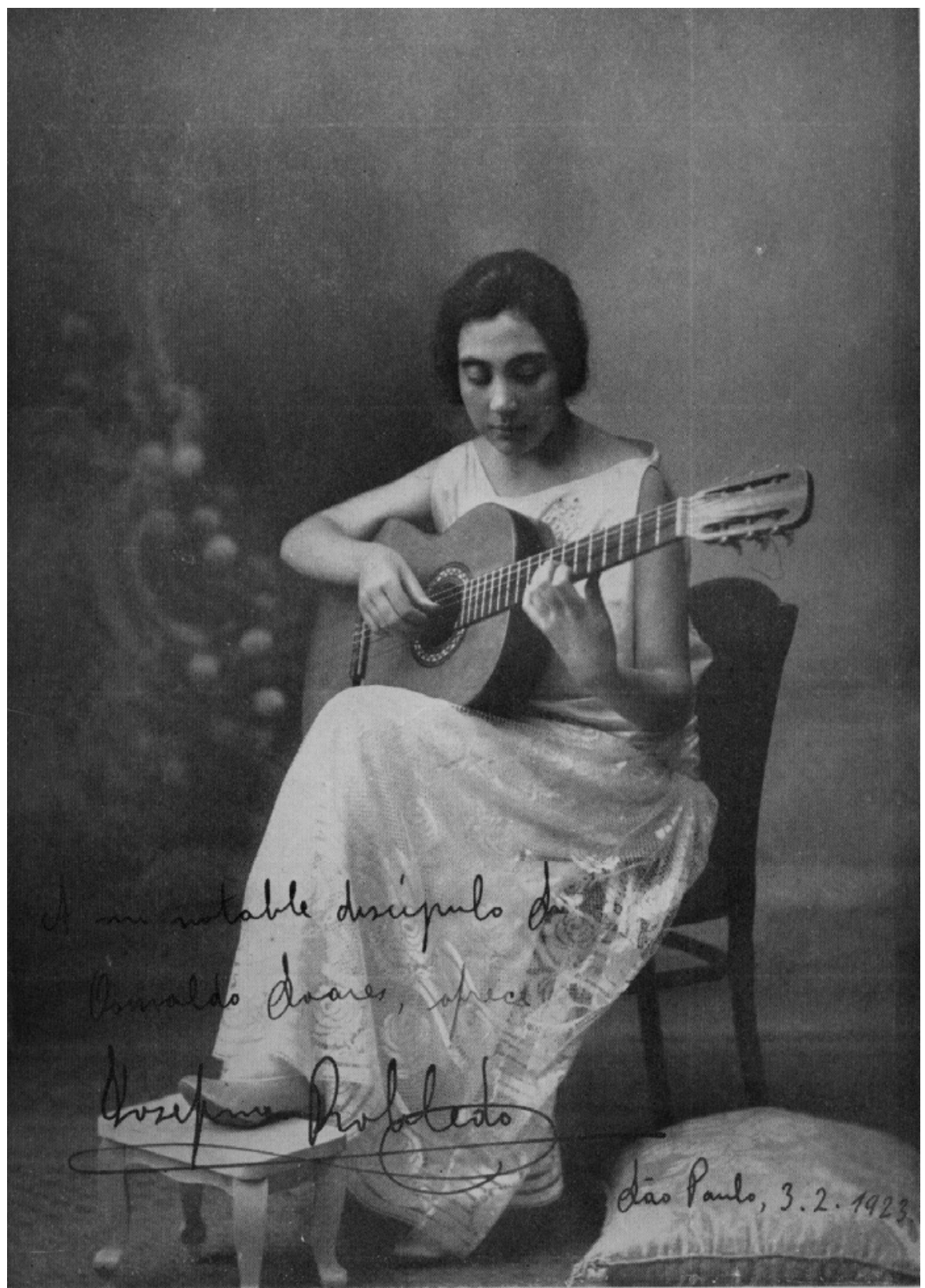

Figura 5. Foto de J osefina Robledo publicada no método de Oswaldo Soares,

A Escola de Tarrega, 1932.

\footnotetext{
${ }^{15}$ Francisco de Assis Tarrega Eixea (1852-1909) - Violonista e compositor espanhol. Tarrega abriu caminho para o renascimento da guitarra do séc.XX dando concertos, transcrevendo obras do piano para o violão, compondo e lecionando. Entre os numerosos alunos, que disseminaram suas idéias pelo mundo, citamos Josefina Robledo, Miguel Llobet e Emilio Pujol que difundiram a Escola Tarrega pela América do Sul, inclusive no Brasil, trazida diretamente por Josefina Robledo.
} 
A repercussão dos concertos da espanhola J osefina Robledo na imprensa brasileira nos dá noção da revolução causada pela chegada da violonista ao país.

A revista $\mathrm{O}$ Violão traz em seu primeiro número:

A rainha do violão terminou aqui a tournée que fez pela América do Sul e taes encantos encontrou em nossa cidade que aqui permaneceu por espaço de dois annos, exercendo o professorado e fundando os alicerces da moderna escola de Tarrega, graças a ella hoje disseminada aqui e em São Paulo onde deixou inúmeros discípulos ${ }^{16}$.

No sexto número da citada revista, encontramos no editorial:

É que até não há muito, no Rio, pouca gente conhecia os maravilhosos e múltiplos recursos do violão. Foi preciso a demonstração pratica da querida discípula de Tarrega, para vermos uma plêiade de moços e pessoas conceituadas em nossa cidade começarem a estudar e a apresentar o fructo de um esforço fecundo ${ }^{17}$. 


\section{Brevemente em S. Pato}

\section{CONCERTO DE Violāo}

da Notavel Artista Hespanhola de Fama Mundial

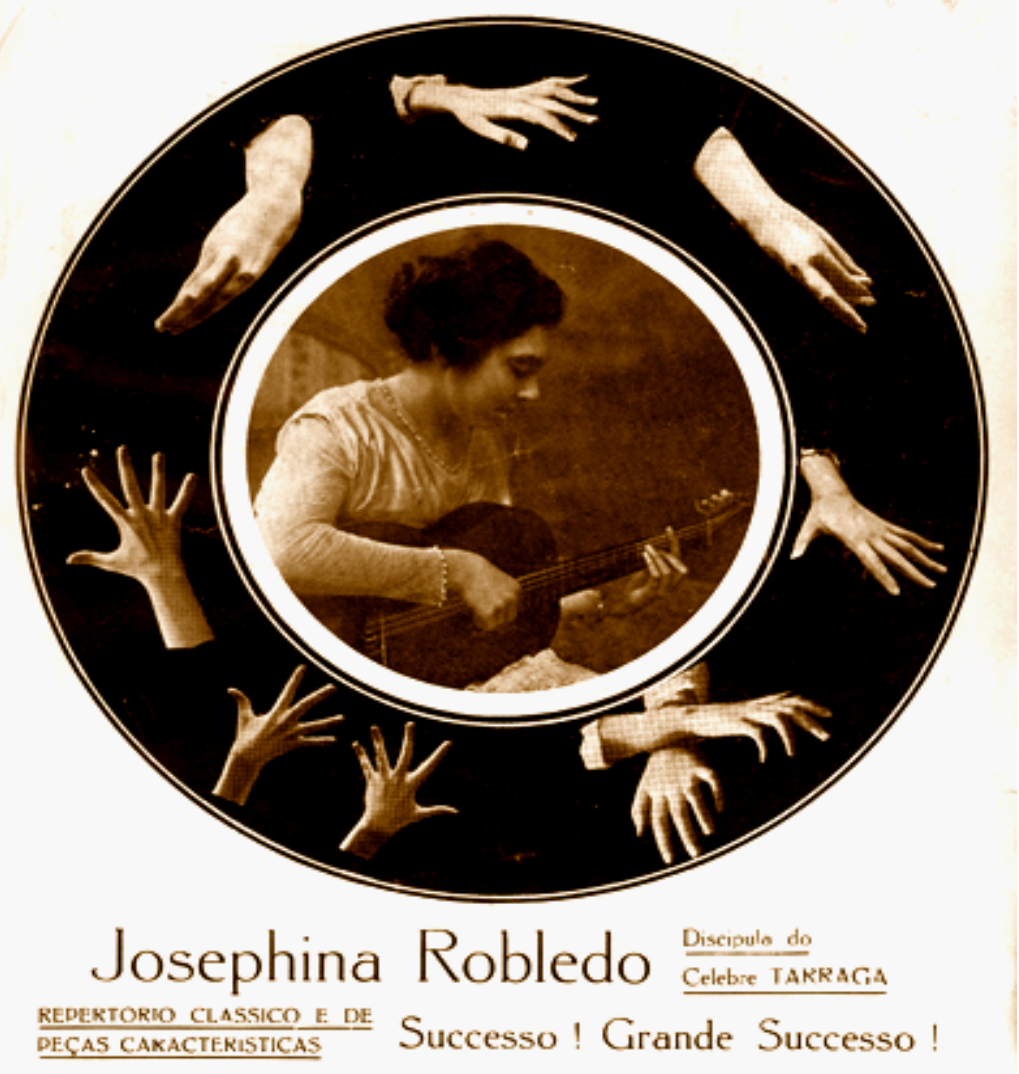

Figura 6. Anúncio do concerto da violinista J osefina Robledo. Revista A Cigarra. 26, jun. 1917.

Citamos abaixo outro trecho do artigo A Literatura de Violão, de Manuel Bandeira (1924):

Josefina Robledo foi discípula de Tárrega, o grande continuador da Escola de Aguado, cuja tradição nos veio transmitir em toda a sua pureza. Deu numerosos concertos aqui e em São Paulo, captando o publico pela suavidade do som e pela simplicidade e justeza de sua técnica. Tocava as passagens mais eriçadas com a mais tranqüila modéstia. Ninguém podia suspeitar que dificuldades ela estava assim vencendo com um sorriso. Era sobretudo notável no arpejo. Josefina 
Robledo começou a formar alguns discípulos entre nós.

Além disso, observando a sua maneira de tocar, os nossos velhos amadores entraram a corrigir e reformar os dedilhados defeituosos que empregavam, de sorte que hoje já se vai começando a tocar com limpeza e estilo ${ }^{18}$.

Catulo da Paixão Cearense organizou um concerto para J osefina Robledo, onde ele recitava poesias. Esta apresentação foi realizada em 24 de setembro de 1917. O poeta Catullo da Paixão Cearense recitou o poema de sua autoria Sonho das Flores acompanhado ao violão pela música de Tárrega. A violonista foi ovacionada e mais uma vez a crítica ressaltou-Ihe o mérito de conseguir interpretações magistrais em um instrumento "tão rudimentar e de limitados recursos". (TABORDA, 2004). Abaixo temos extrato de uma transcrição para violão solo de J osefina Robledo para uma das letras de maior sucesso de Catulo da Paixão Cearense, com música de Pedro Alcântara (1866 - 1929), Ontem ao Luar:

\footnotetext{
${ }^{18}$ BANDEI RA, Manuel. A Literatura do Violão. COLEÇÃO REVISTA DA MÚSICA POPULAR. Edição fac-símile 1954-1956. Rio de Janeiro: Funarte: Bem-te-vi Produções Literárias, 2006, p.621.
} 

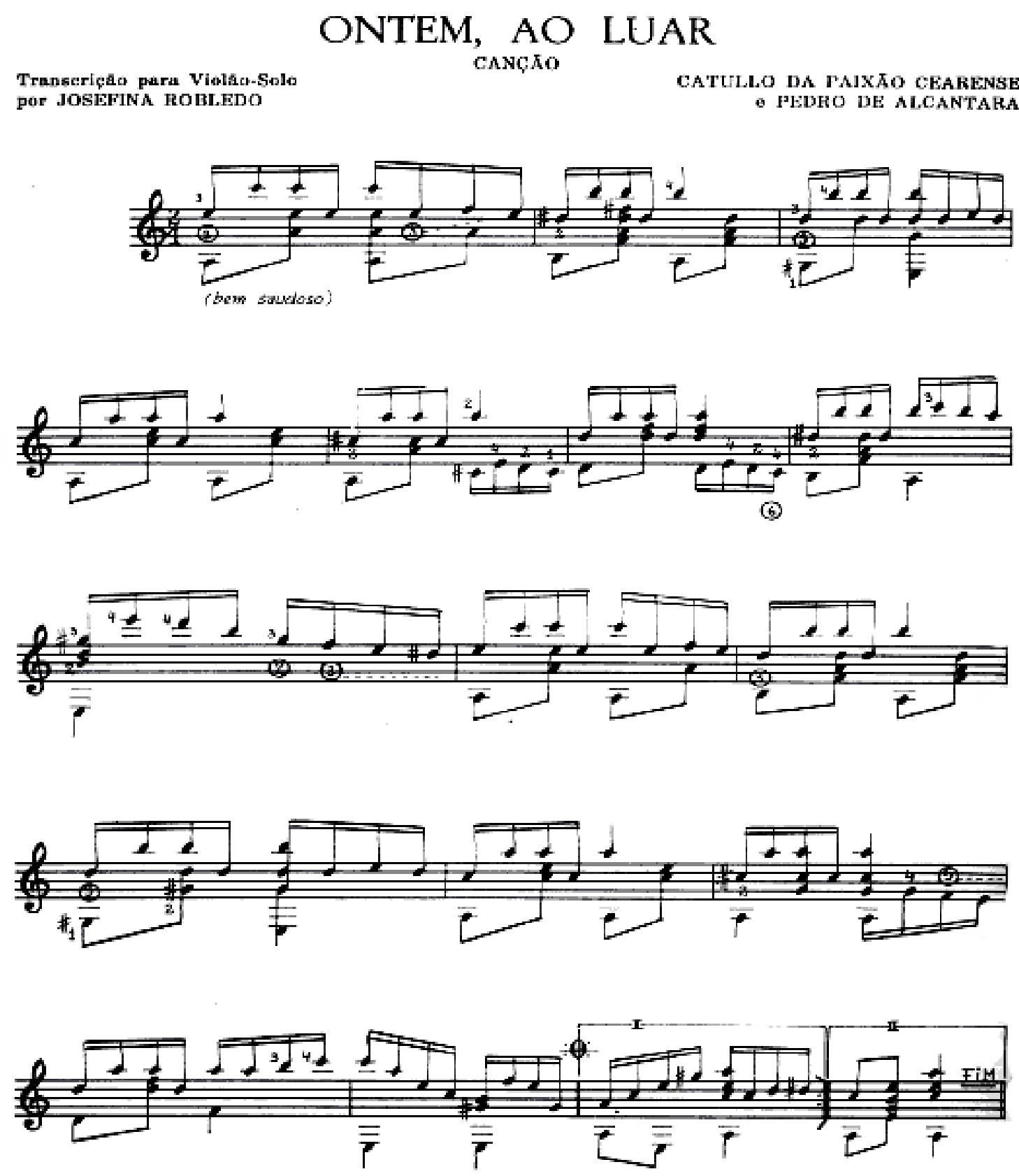

Extrato de partitura 3. Ontem ao Luar, música de Pedro Alcântara e Catulo da Paixão Cearense em arranjo para violão da espanhola Josefina Robledo.

O mais conhecido aluno de J osefina Robledo, o paulista Oswaldo Soares, publicou um método de violão, em 1932, intitulado A Escola de Tarrega - Método Completo de Violão, publicação bastante questionável, assim como sua interpretação da Escola de Tarrega, conforme nos relata J odacil Damasceno: 
Oswaldo Soares pregava a idéia de apoio total ${ }^{19}$. Nunca ouvi ele tocar, só o aluno dele, o Carlos Collet, que tocava tudo com apoio (...) E este era o Oswaldo Soares, que diz que era a Escola de Tarrega, acho que ele ouviu cantar o galo e não sabia bem onde, ele foi aluno da Josefina e a escola da Josefina não é com apoio total, eu consegui um disco com duas músicas que a Josefina toca ${ }^{20}$, uns 10 anos atrás, eu comprei em Sevilha. Uma escola linda, uma gravação caseira, mas um som maravilhoso ${ }^{21}$.

O relacionamento do aluno de Josefina Robledo com Othon

Salleiro foi impossível. De temperamento explosivo, Salleiro chegava às vias de fato com violonistas cuja interpretação ou abordagem do instrumento o desagradasse. Foi assim com Oswaldo Soares, provavelmente por discordar com a interpretação da Escola de Tarrega como uma escola com apoio total, como relata o violonista Jodacil Damasceno em outro trecho da entrevista:
A ABV foi criada em 51, mas houve uma divergência entre o Salleiro e o Oswaldo Soares que era um dos fundadores também, divergência de pensamento, aí, acabou a associação. Em 52, quando eu comecei a estudar com o professor Rebello, ele me convidou para ir à associação, que eles estavam refazendo. 0 Salleiro estava presente, mas o Oswaldo Soares não, saiu definitivamente da associação.

\footnotetext{
${ }^{19}$ Apoio é uma técnica de mão direita que consiste em pinçar uma corda e repousar o dedo na próxima corda, apoiando-o. A idéia do apoio total a que se refere Jodacil Damasceno consiste em apoiar todas as notas, inclusive os arpejos.

${ }^{20}$ Ouvir em cd em anexo, faixa 1.

21 Jodacil Damasceno (1929) é violonista e professor licenciado da Universidade Federal de Uberlândia. Depoimento gravado no Rio de Janeiro, jun. 2006.
} 
Sempre eu acho que houve uma problemática entre o Oswaldo e o Salleiro, tanto que houve a história do recital em 52. Houve um concerto na Escola de Música, em comemoração ao Tarrega. Neste concerto, eu estava começando a estudar. Tocava o Osmar Abreu, Milton de Araújo, Othon Salleiro e Carlos Collet, dileto aluno do Oswaldo Soares. E, não sei muito bem o que aconteceu, mas consta que como o Salleiro era médico do Flamengo, ele levou uma torcida, colocou em cima, no balcão que era para vaiar o Collet caso ele tivesse algum deslize, e o Salleiro provocou o Collet no camarim, para ele ficar nervoso, de fato o Carlos Collet errou muito. Não houve vaias, mas houve uma briga do Salleiro com o Oswaldo Soares, e houve também uma briga na galeria, que seria a torcida do Salleiro, saiu cadeirada, gente correndo, saindo fora lá de cima, foi uma debandada. Resultado, com isto, a escola, que recentemente havia aberto as portas para o violão, voltou a fechar ${ }^{22}$. 
Catulo da Paixão Cearense (1866 - 1946) nasceu no Maranhão. Em 1880, transferiu-se com os pais e irmãos para o Rio de Janeiro, mais precisamente para o bairro de Botafogo. Freqüentava as pensões e repúblicas de estudantes, onde conheceu Anacleto de Medeiros (1866 - 1907), Viriato Figueira da Silva (1851 - 1883), Quincas Laranjeiras (1873-1932), entre tantos outros chorões, começando a estudar violão nesta época, pois até então tocava flauta. Embora não seja propriamente um violonista, o poeta Catulo da Paixão Cearense também é considerado um dos responsáveis pela reabilitação do violão nos salões da alta sociedade. Em 5 de julho de 1908, entrou definitivamente para os anais da música brasileira ao trazer o violão das rodas de seresteiros para o Instituto Nacional de Música (atual Escola de Música da Universidade Federal do Rio de Janeiro - UFRJ) a convite do Maestro Alberto Nepomuceno (1864 1920), então diretor da referida instituição. Nepomuceno organizou um recital de violão no templo da tradição européia: “mal terminava de cantar, rebentavam de todos os lados os aplausos de louco entusiasmo" 23.

Não faltaram críticas a Nepomuceno. Oscar Guanabarino (1851 1937), conhecido opositor de Heitor Villa-Lobos e inimigo feroz do violão, além de ter sido um dos mais influentes críticos de então, considerou uma verdadeira profanação a presença de um violão num salão de música erudita.

\footnotetext{
${ }^{23}$ VASCONCELOS, Ary. Panorama da Música Popular Brasileira na 'Belle Epoque', p. 119.
} 
No prefácio de Lira dos Salões, Luciano Braga nos dá uma idéia do que representou a referida noite:

Poucas vezes aquele estabelecimento terá tido uma enchente, como a do concerto do ilustre poeta. $\mathrm{O}$ auditório foi do que a Capital tem de mais fino nas letras, ciências e artes. Viam-se senhoras de pé, que 0 ambiente regorgitava ${ }^{24}$.

Nas palavras do próprio Catulo da Paixão Cearense:

Músicos, literatos, médicos, jornalistas, advogados, engenheiros, professores, diplomatas, misturaramse a populares ${ }^{25}$.

Neste momento a modinha mudaria de status quo, conquistando o gosto da elite, o mesmo aconteceria com o violão.

\section{Catulo da Paixão Cearense conviveu também com Agustín} Barrios, o relacionamento deve ter sido estreito, como o extrato abaixo nos faz concluir:

Mi gran hermano Catullo quien puede olvidarte? EI recuerdo de tu afecto y de tu genio me acompaña sin cesar atravez de mi interminable peregrinaje por el pais del ensueño... recibe un abrazo fuerte en el que va condensada toda la saudade de mi alma. (Agustín Barrios) ${ }^{26}$.

\footnotetext{
${ }^{24}$ In: VASCONCELOS, Ary. Panorama da música popular brasileira na Belle Epoque. Rio de Janeiro: Livraria Santana, 1977, p.118.

${ }^{25}$ DICIONÁRIO CRAVO ALBIN DA MÚSICA POPULAR BRASILEIRA. Disponível em:

<http://www.dicionariompb.com.br> Acesso em: 04, ago. 2006.

${ }^{26}$ NOGUEIRA, Genésio. Dilermando Reis: Sua majestade o violão. Rio de Janeiro: Edição do Autor, 2000, p.310.
} 
A presença cultural de Catulo da Paixão Cearense foi tão significativa na história da música brasileira, que o escritor Lima Barreto (1881-1922) teria criado em sua homenagem o personagem Ricardo Coração dos Outros, um violonista compositor de modinhas e que é um dos coadjuvantes do romance pré-modernista Triste Fim de Policarpo Quaresma ${ }^{27}$.

Em 1914, conforme já vimos, Catulo da Paixão Cearense foi convidado pela então primeiradama do país, esposa de Hermes da Fonseca, Nair de Teffé, a renomada caricaturista Rian, aluna de violão de Catulo da Paixão Cearense, para um recital no Palácio do Catete. Este foi um dos momentos de maior reconhecimento para o poeta, sendo aplaudido de pé pelo público ao término de cada número.

Poeta e barítono com dicção impecável, Catulo da Paixão Cearense cantava seus versos adaptando-os às melodias dos compositores mais populares da época como Anacleto de Medeiros (1866 - 1907) e Juca Kalut (1857 - 1922). Suas letras ficaram imortalizadas pelas vozes de Mario Pinheiro (1880 - 1923), Eduardo das Neves (1874 - 1919), Vicente Celestino (1894 - 1968), entre tantos. Citamos também sua ligação com J oão Pernambuco, cujas toadas renderam a Catulo da Paixão Cearense dois grandes sucessos: Luar do Sertão ${ }^{28}$ e Cabocla di Caxangá.

\footnotetext{
${ }^{27}$ Ver sobre referido romance no capítulo 1, p. 16.

${ }^{28}$ Catulo da Paixão Cearense negou a parceria com J oão Pernambuco em Luar do Sertão. Villa-Lobos fez questão de assinar documento a respeito dessa controvérsia, confirmando a co-autoria de Pernambuco. In: PRESENÇA DE VILLA-LOBOS, op.cit, p. 141.
} 


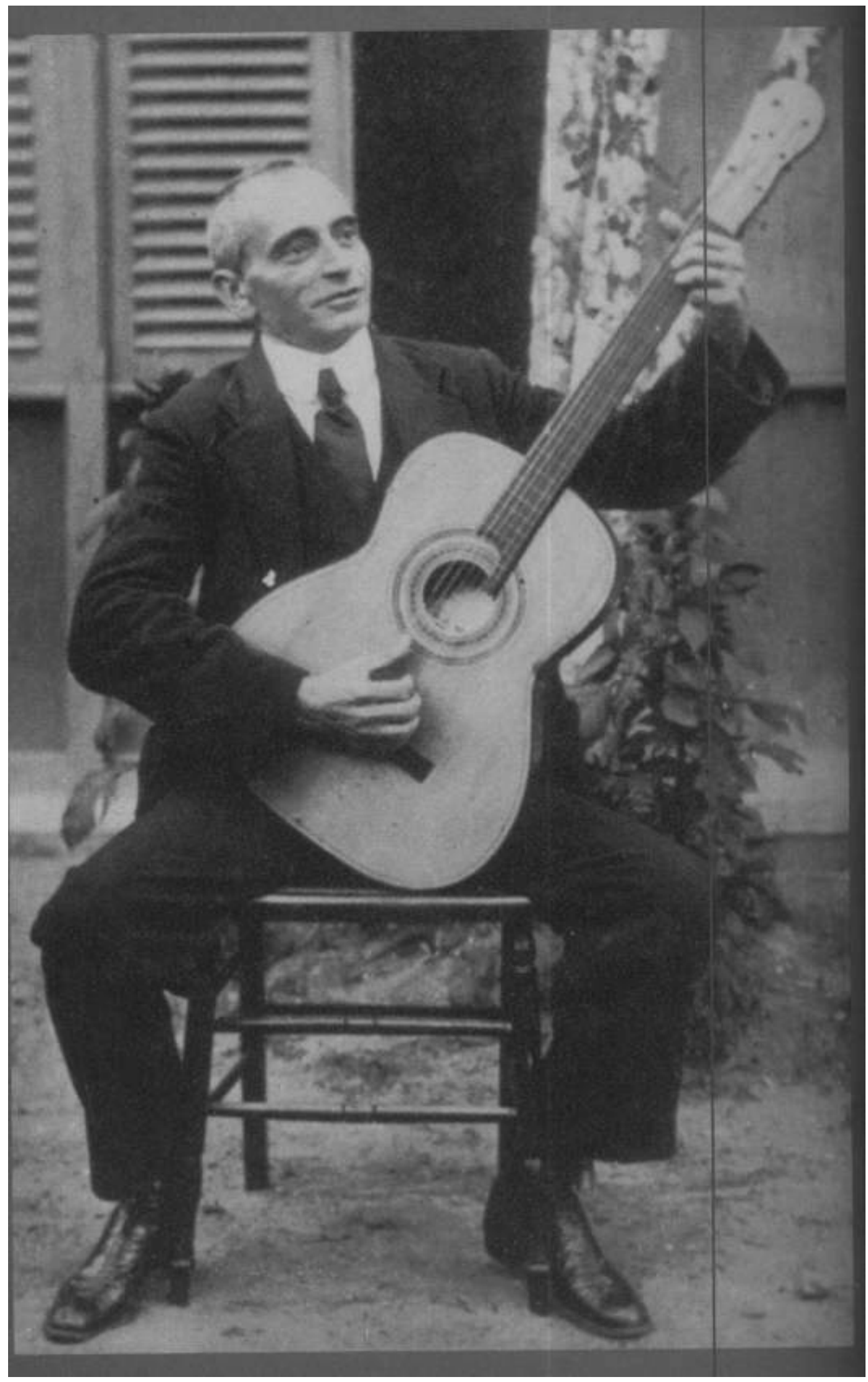

Figura 7. Catulo da Paixão Cearense. 
Outro músico que aparece ligado ao movimento de reabilitação do violão é Ernani de Figueiredo (1860? - 1917), violinista e violonista, natural da cidade de Campos de Goitacazes, estado do Rio de Janeiro. Apresentamos o seguinte texto de Ernani de Figueiredo:

Estudante da divina arte, nunca ouvira de meus professores e colegas senão referências de menoscabo a tal instrumento que reputavam de qualidade e de technica insignificantes. Certo dia, porem, Pedro Silva, camarada meu, amigo de infância(...) entendeu aprender música e violão. Por esssa época, dedicava-me eu ao manejo do arco e da technica do instrumento, Pedro Silva teimou em que eu fosse seu professor. $O$ ensino dos elementos de musica não me foi difícil, mal grado não serem grandes meus conhecimentos, sempre eram muito maiores que os de um leigo; mas o carro pegava pelo violão e a cujos segredos de technica era eu inteiramente alheio. (...) Mas meu amigo não abandonava a resolução de aprender com um mestre que ignorava o instrumento e os autores por onde pudesse orientar-se.

Estavam as cousas nesse pé, quando um dia, Pedro Silva se me apresenta com um velho methodo de Carcassi ${ }^{29}$. 
Encontrando certa dificuldade na tarefa que Ihe foi imposta, Figueiredo começou a freqüentar as serenatas, conforme mostra o texto abaixo:

\begin{abstract}
Quase nullo na techina do instrumento, comecei a observar as queridas serenatas, buscando lobrigar de onde se evolava a fascinação dos tangedores nas noitadas consagradas ao violão. Não fora o receio das conseqüências funestas acarretadas a aqueles que se deixam arrastar, levados pelas ondas sonoras e por um excesso de romantismo, ao vício, diria a todos, sobretudo aos meus alumnos que é nas serenatas onde verdadeiramente se formam as almas dos artistas predestinados a ascender ás culminâncias.
\end{abstract}

Mais a frente, por não conseguir seguir adiante sozinho, na segunda parte do método de Carcassi, Figueiredo recebe aulas de Bernardino J osé Pereira, mais conhecido como Bernardino colchoeiro, por ter uma casa de colchões, à Rua do Rosário, na cidade de Campos. Ernani de Figueiredo relata então que passou a freqüentar as serenatas. O repertório das noitadas de violão era composto de peças progressivas do próprio método de Carcassi e de uma ou outra peça avulsa.

Mudando-se para a capital federal, conhece Quincas Laranjeiras, e começam as audições, como nos relata na mesma palestra:

Além de Quincas Laranjeira e eu, contavam Fernando Senra, Arthidoro Costa, Zezé Fragoso, José e Mario do Cavaquinho e por fim Levino da 
Conceição, cego do Instituto Benjamin Constant, com o qual eu e o Santos [Quincas Laranjeiras] demos um concerto no Conservatório Livre do Rio de J aneiro.

Logo depois, Quincas Laranjeira seria convidado para acompanhar Catullo da Paixão Cearense em uma audição no Instituto Nacional de Música, onde teve a oportunidade de, ao lado de Alfredo Imenez e Santos Coelho, apresentar o violão na exhibicão dos clássicos ${ }^{30}$.

Destacamos ainda o papel da obra para violão de Heitor VillaLobos (1887 - 1959), que teve caráter decisivo para o desenvolvimento do violão como instrumento de concerto no país.

Ressaltamos a influência dos métodos e do repertório de guitarristas europeus da primeira metade do século XIX. Os estudos de métodos de Dionísio Aguado (1784 - 1849), Fernando Sor (1778 1839), Francisco Molino (1775-1847) e Matteo Carcassi (1792 1853) incorporam-se ao repertório do violão brasileiro, influenciando a técnica, o ensino e impulsionando o instrumento a abandonar a posição de acompanhador para passar a solista, como veremos adiante, começando também a freqüentar as classes mais privilegiadas.

O Método Completo, op.59, de Matteo Carcassi foi bastante difundido na metade do século XIX no Rio de Janeiro. Editado originalmente em 1829, em Paris, aparece em edição brasileira, pela Laforge, em 1837 (TABORDA, 2004) e em 1943 pela Casa Bevilacqua.

\footnotetext{
${ }^{30}$ In: O VIOLÃO, Rio de Janeiro, 1929, n 3, p.7. Ver detalhes sobre a referida audição na p.40.
} 
Também de Carcassi, o opus 60, com 25 estudos, está entre as melhores obras didáticas do século XIX para o instrumento e até hoje é publicado no Brasil.

Luiz Otavio Braga (1953) comenta estes cruzamentos que fizeram parte da aceitação do violão:

(...) Finalmente, uma instância de mediação que requer atenção é aquela configurada por determinados músicos populares que em períodos determinados transitaram nos meios sociais das elites culturais fazendo-Ihes participar da cultura popular e chamando a atenção das elites que produziam a arte considerada culta do período. Assim poderíamos considerar, nas primeiras décadas do século, Catulo da Paixão. Como Sinhô durante o último quartel dos anos 20 , símbolo de impressão marcante do popular na obra poética de Bandeira; Pixinguinha e os parceiros dos 8 Batutas que celebrizaram encontros no melhor estilo da geração boêmia, com Olegário Mariano, Afonso Arinos, presidente da Academia Brasileira de Letras, Hermes Fontes, Gutemberg Cruz, Catulo da Paixão Cearense e outros. Donga relata que esses poetas iam mesmo buscá-los numa cabeça-deporco em que o grupo morava na Rua do Riachuelo, $268{ }^{31}$. Diz:

'Nós ficávamos ali improvisando, tocando, cada um solando alguma coisa e os poetas dizendo os versos. Isto até romper o dia, depois íamos para aquele largo da Avenida Gomes Freire (...) onde o

\footnotetext{
${ }^{31}$ BRAGA, Luiz Otávio Rendeiro Correa. A Invenção da Música Popular Brasileira: de 1930 ao final do Estado Novo, 2002. 408 f. Tese (Doutorado em História Social) - Instituto de Filosofia e Ciências Sociais, Universidade Federal do Rio de Janeiro, Rio de Janeiro. 2002.
} 
J oão Pernambuco morou mais tarde. Nessa praça tinha um bar, no qual sentávamos e rompíamos o dia. Era um meio de literatos que apreciavam música e músicos que apreciavam poesia. Foi assim que eu me ambientei' ${ }^{32}$.

Devemos ressaltar que a reabilitação do violão se deu pela inserção do instrumento nas camadas mais altas da sociedade, como pode-se constatar através dos conteúdos da revista O Violão (19281929), no entanto, tratava-se de uma prática essencialmente popular. A introdução dos princípios de Francisco Tarrega ainda aparece em segundo plano.

O violão tratado como instrumento solista e de concerto tomará novos rumos com o pioneirismo do violonista e professor uruguaio Isaias Sávio (1900-1977), que introduziu o violão no ensino oficial de música no Brasil, quando ingressou no Conservatório Dramático e Musical (1947), em São Paulo.

A guisa de conclusão, julgamos interessante citar a reflexão de Alfredo Bosi (1936), escritor, ensaísta e professor de Literatura Brasileira da Universidade de São Paulo, sobre estas áreas de intersecção que abordamos nos dois primeiros capítulos e que são o ponto de partida para a compreensão da formação violão brasileiro:

(...) a cultura popular está generosamente aberta a múltiplas influências e sugestões, sem preconceito de cor, classe ou nação. E, o que é rico em conseqüências, sem preconceito de tempo. A 
cultura do povo é localista por fatalidade ecológica, mas na sua dialética humilde é virtualmente universal: nada refuga por princípio, tudo assimila e refaz por necessidade ${ }^{33}$. 


\section{O Violão no Rio de Janeiro ( 1868 - 1950).}

\subsection{Precursores de Othon Salleiro}

Othon Salleiro começa a apresentar-se em recitais de violão solo aos 19 anos (1929). Suas composições são exclusivamente para violão solo, não temos notícias de peças que tenham sido escritas para outro instrumento ou formações. Neste capítulo, buscamos rastrear as influências que teriam levado Salleiro a contrariar a tradição de inserir-se nos conjuntos populares, dedicando-se ao violão solo, e procuramos parâmetros para a melhor compreensão da linguagem instrumental desenvolvida por este violonista.

No livro de Ayres de Andrade, Francisco Manuel da Silva e Seu tempo: 1808 - 1865. Uma Fase do Passado Musical do Rio de Janeiro a Luz de Novos Documentos (1967), contamos não mais que quinze professores, a maioria oriundos da Europa, que ensinam violão e lecionam vários outros instrumentos no período compreendido. Em curto espaço de tempo, no livro Panorama da Música Popular Brasileira na Belle Époque (1977), de Ary Vasconcelos, que compreende biografias de músicos entre os anos de 1870 a 1919, contam-se mais de oitenta nomes de violonistas, excetuando-se os músicos que aparecem como cantores e violonistas ou que lecionam violão e outros instrumentos. Estes nomes chegaram até nós pela prosa tosca de Alexandre Gonçalves Pinto, vulgo Animal, em O 
Choro: Reminiscências dos Chorões Antigos, livro que é fonte maior para o citado livro de Vasconcelos.

Apesar das poucas informações objetivas e os incontáveis erros de português, o livro de Alexandre Gonçalves Pinto é a primeira fonte que reúne estes nomes da música popular brasileira que a história oficial da República fez questão de apagar. É precioso como inventário do choro, pois nos dá uma idéia do grande movimento que a música popular produzia às margens da cultura oficial do país. Destes nomes, desconhecemos datas precisas de nascimento e morte e muitas vezes somente o apelido chegou até nós.

As primeiras referências ao violão na capital aparecem em periódicos como o Spectador brasileiro que, em 1826, traz anúncio de Bartolomeu Bortollazzi:

Professor de música, morador na Rua dos Inválidos № 80, faz sciente ao responsável público que, quem quizer aprender música, cantar, tocar viola, viola franceza ou mandolino, que elle ensina ${ }^{1}$.

Fernando Martinez Hidalgo aparece como professor de violão e canto e compositor de modinhas, de 1855 a $1890^{2}$.

\footnotetext{
${ }^{1}$ Apud. TABORDA, Marcia Ermelindo. Violão e I dentidade Nacional: Rio de Janeiro 1830/1930. Tese de Doutorado, UFRJ: Rio de Janeiro, 2004.

${ }^{2}$ ANDRADE, Ayres de. Francisco Manuel da Silva e seu tempo: 1808-1865. Uma fase do passado musical do Rio de Janeiro à luz de novos documentos. 1. ed. Rio de Janeiro: Edições Tempo Brasileiro, 1967.
} 
0 V JOL $\mathrm{E} 0$

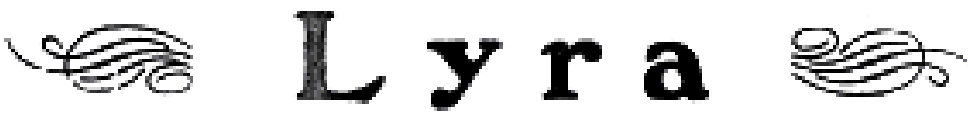

(NODIXHA)

Masice de J. 1. de Alscido Flonivg.

Para riolate - i. F. Slidalgo
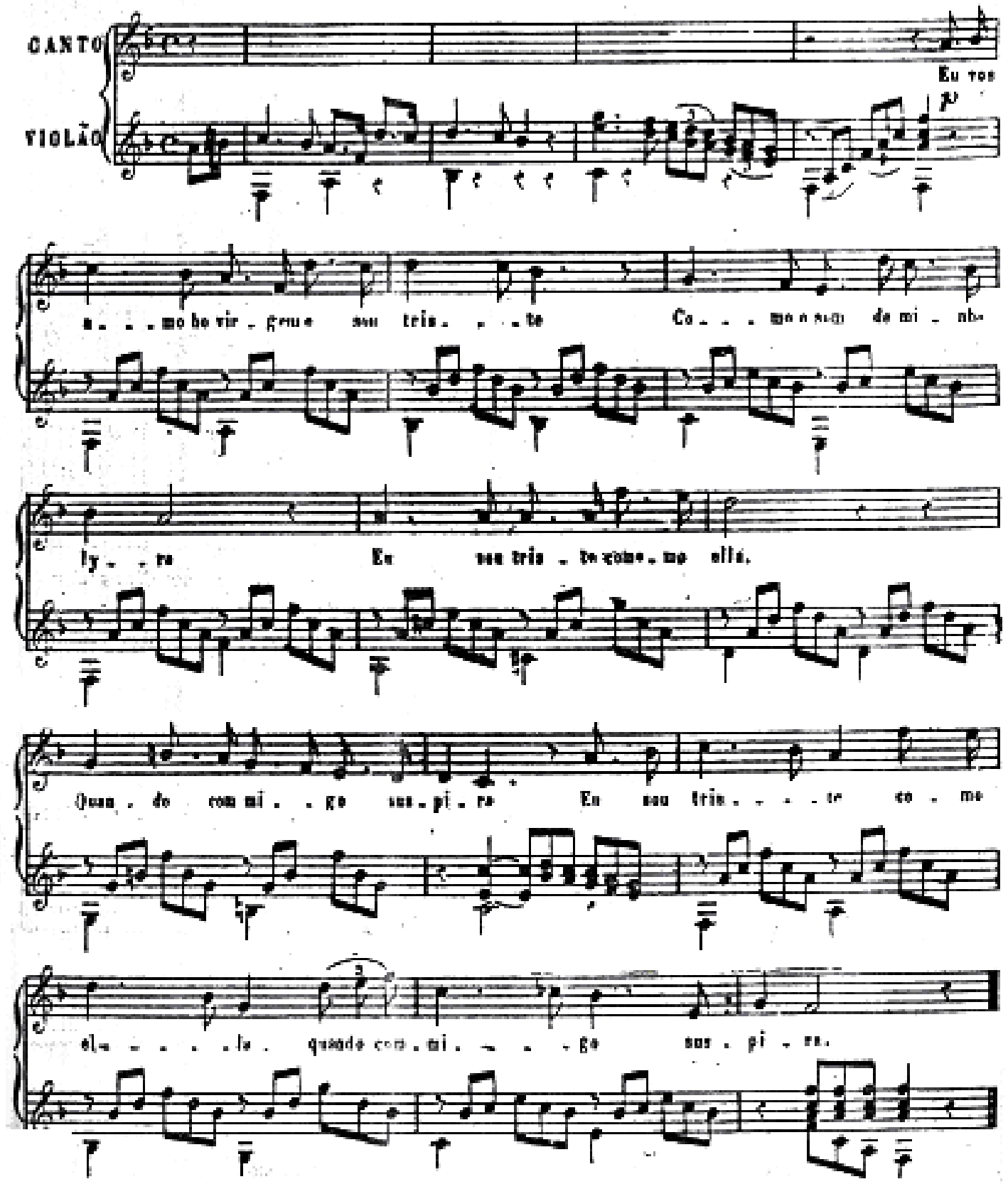

Extrato de partitura 4. Modinha de Hidalgo, publicada na revista O violão, abril, 1929. 
Marcia Taborda nos dá a notícia do que seria o primeiro concerto solo de violão realizado no Rio de Janeiro:

O semanário Vida Fluminense (junho/1868, o17), numa crítica ao concerto inaugural realizado no Club Mozart, informou que a sociedade "foi palco para uma rara apresentação violonística":

Lisboa, um dos amadores mais notáveis do Rio de Janeiro, começou a desferir do seu violão sons tão repassados de melodia, que deixavam em dúvida o instrumento de que eram arrancados. Todos sabem que o violão não se presta facilmente aos cantos ligados nem à pureza dos sons se o trecho que cai executar se requer velocidade de digitação pois bem: ouçam a fantasia da 'Traviata' e a'Faceira' e digam-se depois se continuam a pensar assim.

Trata-se de Clementino Lisboa, engenheiro formado e violonista amador. Em artigo publicado na revista "O violão" (1929), redigido a partir de informações dadas pelo pianista Arthur Napoleão, Lisboa é lembrado como o "primeiro heroe" a apresentar o instrumento em versão solista ${ }^{3}$.

Em 1887, a compositora Chiquinha Gonzaga organizou no Teatro São Pedro, Rio de Janeiro, um concerto com cem violões ${ }^{4}$.

Informações mais precisas sobre os violonistas Alfredo Souza Imenez, Melchior Cortez, Gustavo Ribeiro e Brant Horta foram encontradas no já citado Diccionario de Guitarristas de Domingo Prat:

\footnotetext{
${ }^{3}$ APUD. TABORDA, Marcia Ermelindo. Op. cit, p. 62.

${ }^{4}$ ENCICLOPÉDIA DA MÚSICA BRASILEIRA: popular, erudita e folclórica. 2. ed. São Paulo: Art Editora: Publifolha, 1988, p. 340.
} 
Alfredo Souza I menez (1865 - 1918) nasceu no Rio de Janeiro, dominava a teoria e a técnica de Aguado. Foi para o Uruguai e Argentina, onde se radicou entre 1892 e 93. Ali conviveu com os violonistas: Gaspar Sagreras, A. Jimenez Manjon, Juan Alais e Garcia Tolsa. De volta ao Rio de Janeiro, atuou em diversos concertos com músicas próprias, composições de Manjon e Garcia Tolsa e fantasias com temas de óperas e transcrições dos músicos célebres, adaptados pelo próprio Souza I menez para o violão. Em 1904 parte para os Estados Unidos e foi diretor da Metropolitan Mandolin Orchestry, onde executava violão baixo, com doze cordas.

Melchior Cortez ( 1882 - ?) nasceu em Portugal, aos nove anos mudou-se para o Rio de Janeiro, foi aluno de Souza Imenez, e conforme vimos no segundo capítulo, era renomado professor da alta sociedade carioca. Prat enumera mais de uma dezena de alunas de Cortez e diz "há tantas outras de não menos importância" 5. Atuou ao lado de Quincas Laranjeiras em concerto no Salão do Casino Copacabana (1927). Publicou em 1927, pela Casa Romero y Fernandez, Escola de Arpejos para Violão, estando incluído entre eles, progressivamente ordenados, fórmulas de Fernando Sor, Dionísio Aguado, Ferdinando Carulli, Matteo Carcassi, Mario Rodrigues Arenas, Julio Sagreras, Antonio Jimenez Manjon, Antonio Cano, Prat e a maioria do próprio Melchior Cortez.

Brant Horta (1876 - 1940?) - poeta, filólogo, violonista natural de Juiz de Fora, Minas Gerais, professor de português. No Rio de Janeiro,

\footnotetext{
${ }^{5}$ In: PRAT, Domingo. Op.cit, p.94.
} 
passou a lecionar na Escola Normal e seguiu atuando e lecionando violão. Publicou várias obras didáticas, entre elas: Noções de Gramática Histórica (1932) e Gramática Intuitiva da Língua Portuguesa (s/d) e livros de poesia como Lyriae Carmen (1905) e Harpa Eólea (1912).

Gustavo Ribeiro (? - ?) Aparece como professor de violão em anúncios da revista O Violão (1928-29). Sobre Ribeiro, Prat destaca principalmente sua atividade com didata, destacando alguns alunos: Regina de Rezende, Astria Vieria, Lea Baronkel, Juan Lyra, N. Villas Boas e Othon Sivaldo Vaz Salleiro (grifo nosso).

Lembramos que nesta época o violão era, na maioria das vezes, ensinado de forma oral, ou seja, sem o uso de partituras. Os violonistas que sabiam ler partituras normalmente executavam também outro instrumento: Quincas Laranjeiras era flautista, Ernani Figueiredo era violinista e Levino da Conceição era cego e estudou música no Instituto Benjamin Constant.

Sobre Levino da Conceição (1895-1955), dispomos de poucas referências Nascido em Cuiabá, Mato Grosso, ficou cego aos sete anos, quando começou a aprender música. Aos 12 anos já mostrava total domínio do violão, sendo capaz de improvisar e dominar todos os tons (KFOURI, 2004). 


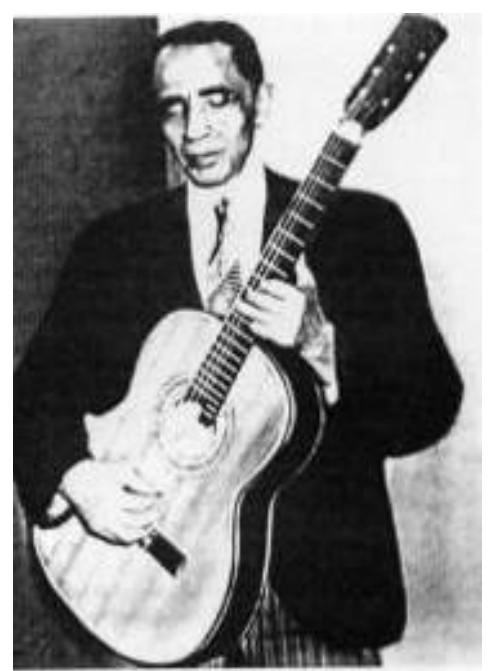

Figura 8. O compositor, violonista e professor cego Levino da Conceição

Mudou-se para o Rio de Janeiro e foi estudar música no Instituto Benjamim Constant. A partir de 1917, iniciou trabalho de ensino de música para cegos, tendo incentivado a criação de escolas para cegos no Rio de Janeiro.

Em 1925, o poeta Manuel Bandeira descreve um concerto que assistira do violonista:

\section{Violão de Levino}

Registramos também nesta crônica o concerto de violão do nosso Levino Conceição. Levino tem um mecanismo vertiginoso. Raramente se atropela e quando tal the sucede, sente-se que foi por traição do tato, desajudado da vista que Ihe falta.

A sonoridade é redonda, vibrante, comovente. Como compositor do instrumento, é ótimo, com recursos característicos, o que mostrou no maxixe Há quem resista?, de fato irresistível, e no romance Alma Apaixonada.

É pena que os violonistas não organizem os seus programas com alguns números de canto. Afinal o violão 
é por excelência instrumento acompanhador e irmão gêmeo da modinha. Como os concertos de violão ficariam agradáveis, pondo-se de parte as reduções pobríssimas de músicas clássicas e óperas em favor do canto característico de nossa gente! O sucesso seria outro. Haja vista o agrado que causou a modinha intercalada na Terra Caída de Catulo, cantada pelo autor e deliciosamente acompanhada por Levino ${ }^{6}$. (grifo nosso) 


\section{Há Quem Resista?}

Chồo
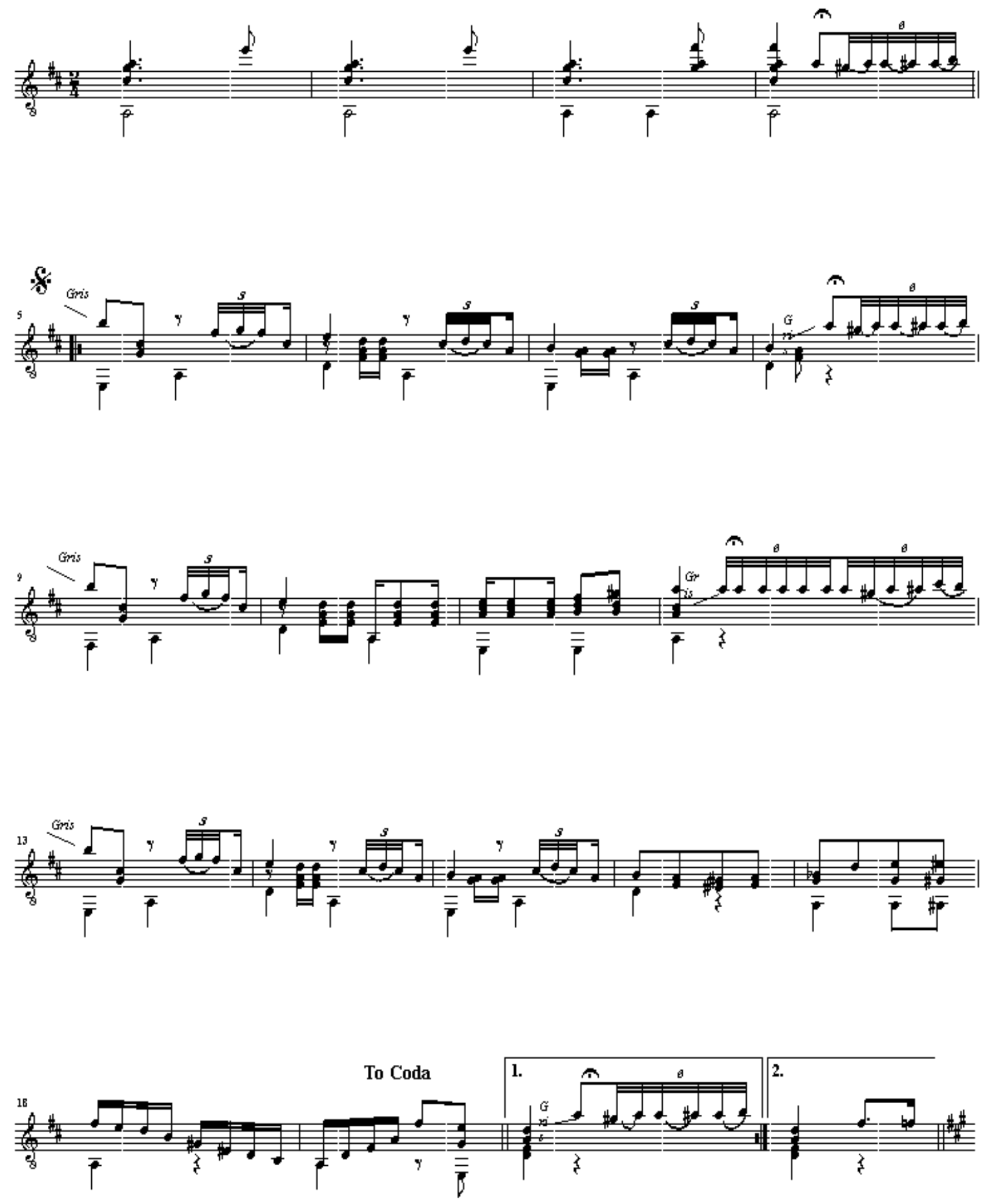

Extrato de Partitura 5. Choro de Levino da Conceição: Há quem resista? 
Seu discípulo e rival de Othon Salleiro, Dilermando Reis registrou duas composições do mestre: Canção Gaúcha, no disco Junto a teu coração ${ }^{7}$ e Cateretê Mineiro, no disco Gotas de Lágrimas ${ }^{8}$.

O próprio Levino da Conceição gravou, em 78 rpm, Triste ausência e Carioca (Odeon, s/d), Saudades do Rio Grande e Reminiscências baianas (Odeon, s/d); Há quem resista? E El pasado (Audacioso) (Odeon, s/d); Prece, Canção gaúcho (Odeon, 1930); Meditando e Romance (Odeon, 1930), todas de sua autoria, com exceção da última, de Robert Schumann $(1810-1856)$.

Meditando e Romance podem ser ouvidas, na interpretação de Levino da Conceição, no CD número 10 da caixa com 15 CDS, intitulada Memórias Musicais da Casa Edison, lançada em 2002 pela gravadora Biscoito Fino, em conjunto com o Instituto Moreira Salles.

Agustín Barrios fez dois registros da música Tarantela de Levino da Conceição, em 1921 e 1928.

\section{J oaquim Francisco dos Santos (1873-1932) ou Quincas}

Laranjeiras, natural de Pernambuco, foi um dos pioneiros no ensino de violão por música ${ }^{9}$ no Rio de Janeiro, divulgando os rudimentos da escola de Francisco Tárrega e foi, conforme veremos adiante, professor de Othon Salleiro (grifo nosso). Sua família fixou residência no Rio de

\footnotetext{
${ }^{7}$ Gravadora Continental, 1964.

${ }^{8}$ Gravadora Continental, 1965.

${ }^{9}$ A expressão por música refere-se ao uso da partitura, em oposição a de ouvido, forma de transmissão do aprendizado musical via tradição oral, muito usual no ensino do violão.
} 
Janeiro ${ }^{10}$ e aos 11 anos, Joaquim dos Santos trabalhava na Fábrica de Tecidos Aliança.

A referida fábrica mantinha uma banda e foi onde Quincas Laranjeiras começou a estudar flauta. Em pouco tempo passou a ser assistenteregente, orientando os alunos iniciantes, já deixando antever aquela que seria sua maior habilidade: ensinar.

Quando se dedica ao violão, logo se sobressai como excelente solista e acompanhador participando dos saraus (KFOURI, 2004) organizados por Alfredo da Rocha Vianna (1860? - 1917), pai de Pixinguinha. Estes saraus reuniam músicos como Heitor Villa-Lobos e Sátiro Bilhar.

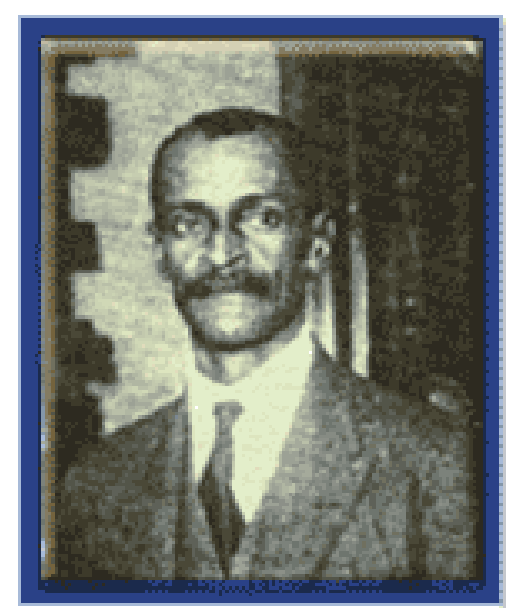

Figura 9. Quincas Laranjeiras

A maioria das obras de Quincas Laranjeiras foi extraviada.

Conhecemos a polca Sabará que foi registrada em CD recentemente pelas gravadoras Acari e Biscoito Fino em 2002, dentro da série Princípios do Choro ${ }^{11}$.

\footnotetext{
${ }^{10}$ J oaquim Francisco dos Santos chegando ao Rio de Janeiro, fixou-se no bairro das Laranjeiras, vem daí o nome pelo qual ficou conhecido. Encontramos duas grafias para o codnome do violonista: Quincas Laranjeiras ou Quincas Laranjeira.

${ }^{11}$ RABELLO, Luciana, cavaquinho; SILVA, Celso J osé da, pandeiro; SOUZA, Rogério, violão; AZEVEDO, Nailor Aparecido [Proveta], Saxofone alto e CARRILHO, Maurício, violão de 7 cordas. PRINCíPIOS DO CHORO. Rio de Janeiro: Acari, Biscoito Fino, 2001. v.4, Cd n. 11, faixa 15.
} 
O extrato abaixo pertence à Coleção Cadernos de Choro ${ }^{12}$ uma publicação de cinco volumes.

\section{Sabará}

choro

Quincas Laranjeiras

adaptagāo: Mauricio Carrilho
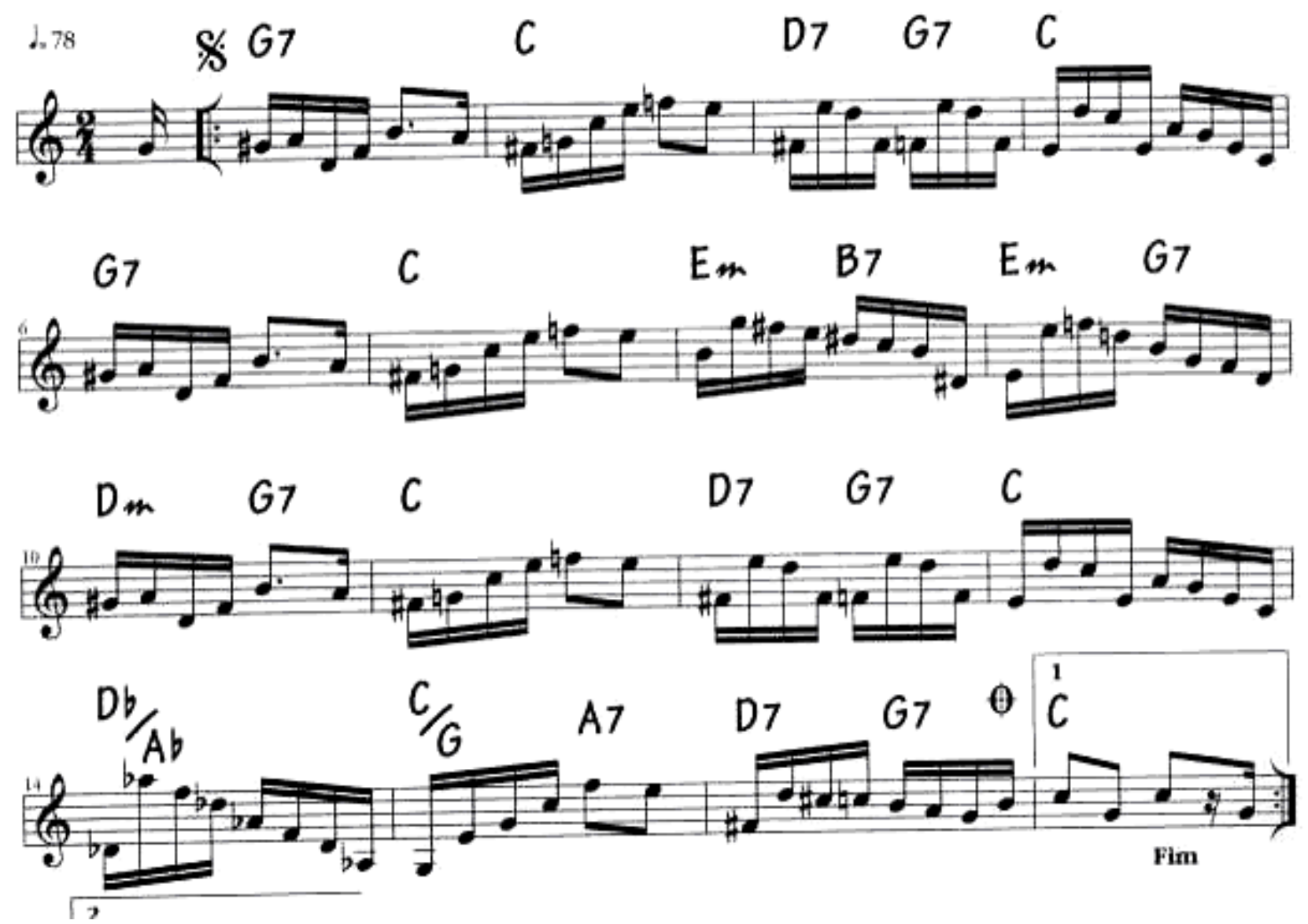

Extrato de partitura 6, Sabará, choro de Quincas Laranjeiras, com adaptação de Maurício Carrilho.

Dores d'alma é uma das poucas partituras para violão solo que conhecemos, o extrato abaixo é uma versão digitalizada que nos foi cedida pelo violonista Nélio Rodrigues:

\footnotetext{
${ }^{12}$ In: PRINCÍPIOS DO CHORO, v. 4, p.98. Os Cadernos fazem parte do projeto Princípios do Choro, citado acima. A série tem organização dos violonistas Maurício Carrilho (1957) e Anna Paes e é uma co-produção Acari Records, Biscoito Fino e Editora da UERJ (Universidade do Estado do Rio de Janeiro).
} 
Dores d'alma

Valsa
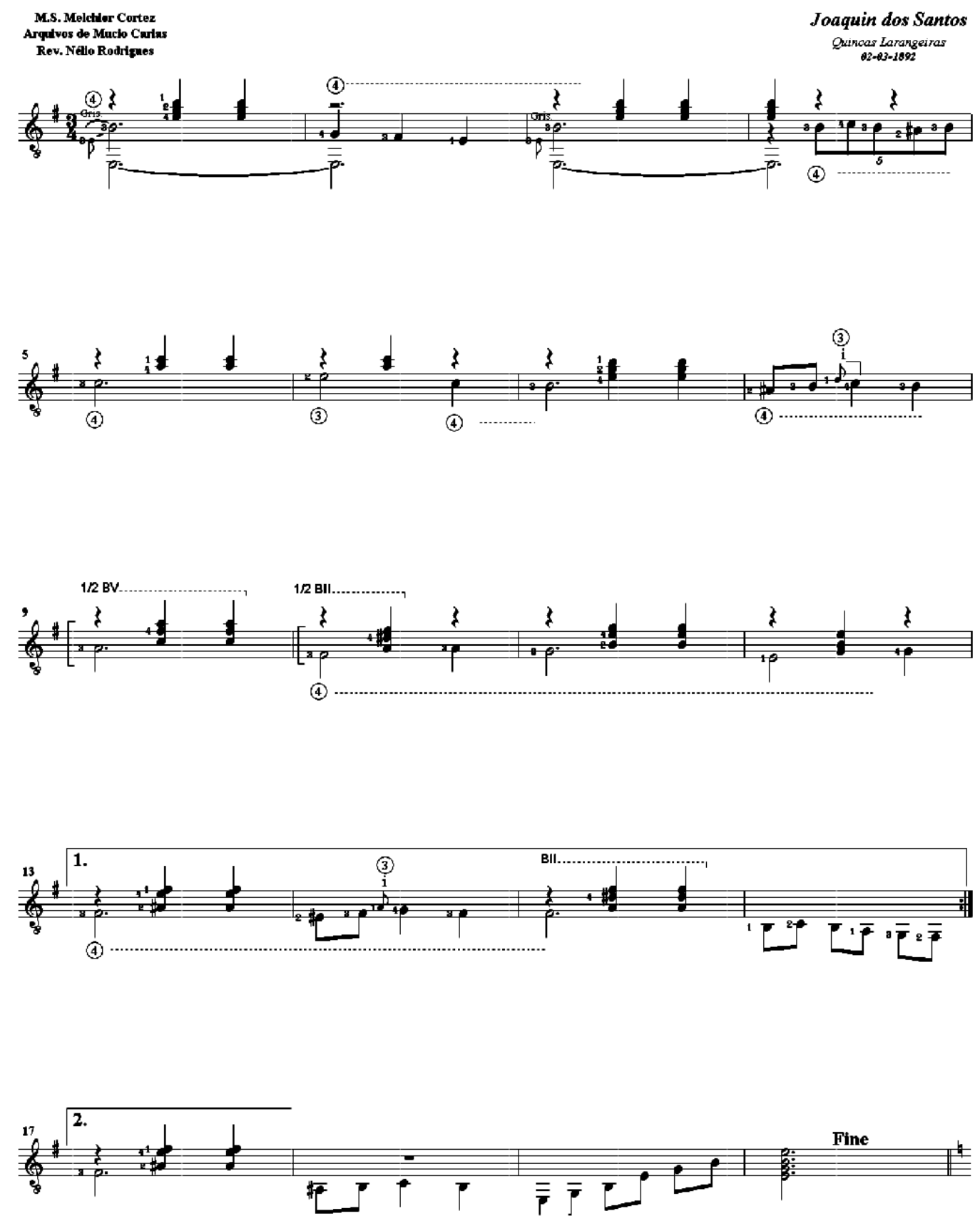

Extrato de partitura 7. Dores d'alma, valsa de Quincas Laranjeiras, por Nélio Rodrigues. 
Foram remasterizadas recentemente pelo selo Biscoito Fino - as primeiras gravações brasileiras das Casas Edson, sob o nome de Memórias Musicais. Nesta coleção, há um registro do regional K. Laranjeira ${ }^{13}$, com o Quincas Laranjeiras ao violão, executando a polca Não tens coração, de Antonio Maria Passos (1880 - ?) ${ }^{14}$.

Em 1900, Laranjeiras criou a Estudantina Arcas ${ }^{15}$, escola de música e ponto de encontro entre chorões ${ }^{16}$. Dez anos mais tarde lecionou na loja de instrumentos Ao Cavaquinho de Ouro, onde conheceu J oão Pernambuco, que, além de seu amigo, também foi seu aluno. No início da década de 30, Quincas Laranjeiras foi professor de Antonio Rebello, José Augusto Freitas, Donga e Othon Salleiro.

Nos últimos anos de sua vida colaborou para a revista O Violão, harmonizando canções brasileiras para o instrumento.

Sobre Quincas Laranjeiras, o primeiro número da revista O Violão traz:

Homem consciente, modesto e probo, fez disso sacerdócio, ministrando a seus discípulos seus criteriosos ensinamentos, com aquela simplicidade que o tornou querido de toda a nossa sociedade. Pode-se, por isso, dizer com justiça que Quincas Laranjeiras é o avô do violão moderno. A ele se devem mais do que a qualquer outro, Os primeiros passos no estudo do violão ${ }^{17}$.

\footnotetext{
${ }^{13}$ In: MEMÓRIAS MUSICAIS. Rio de Janeiro: Biscoito Fino, 2003, Cd n. 6, faixa 1. BF601-6. Ouvir cd em anexo, faixa 4.

${ }^{14}$ Ver encarte de MEMÓRIAS MUSICAIS. Rio de Janeiro: Biscoito Fino, 2003, p. 13.

15 Em relação ao nome da escola, presumimos ser referência ao célebre violonista espanhol Julian Arcas (1832-

1882), o que reforça a idéia do conhecimento de Quincas Laranjeiras da escola formal do ensino de violão.

${ }^{16}$ Nome dado aos músicos, compositores e instrumentistas que se dedicam a cultivar o gênero instrumental Choro.

${ }^{17}$ Revista O VIOLÃO. Rio de Janeiro, $\mathrm{n}^{\circ} 1$ dezembro de 1928.
} 
Juntamente com Sátiro Bilhar, Quincas Laranjeiras foi um dos pioneiros do violão no choro carioca (KFOURI, 2004).

Assim como no caso de Bilhar, a atuação de Laranjeiras como músico aconteceu anteriormente à profissionalização dos instrumentistas, ocasionada pelo disco e pelo rádio e por esta razão, desconhecemos a maior parte de sua produção.

Segue um exemplo das harmonizações feitas por Quincas Laranjeiras para a revista O Violão:

O VIOLE Dezembro de 1928

A CASINHA DE MEU BEM armujo de josquim nos santos

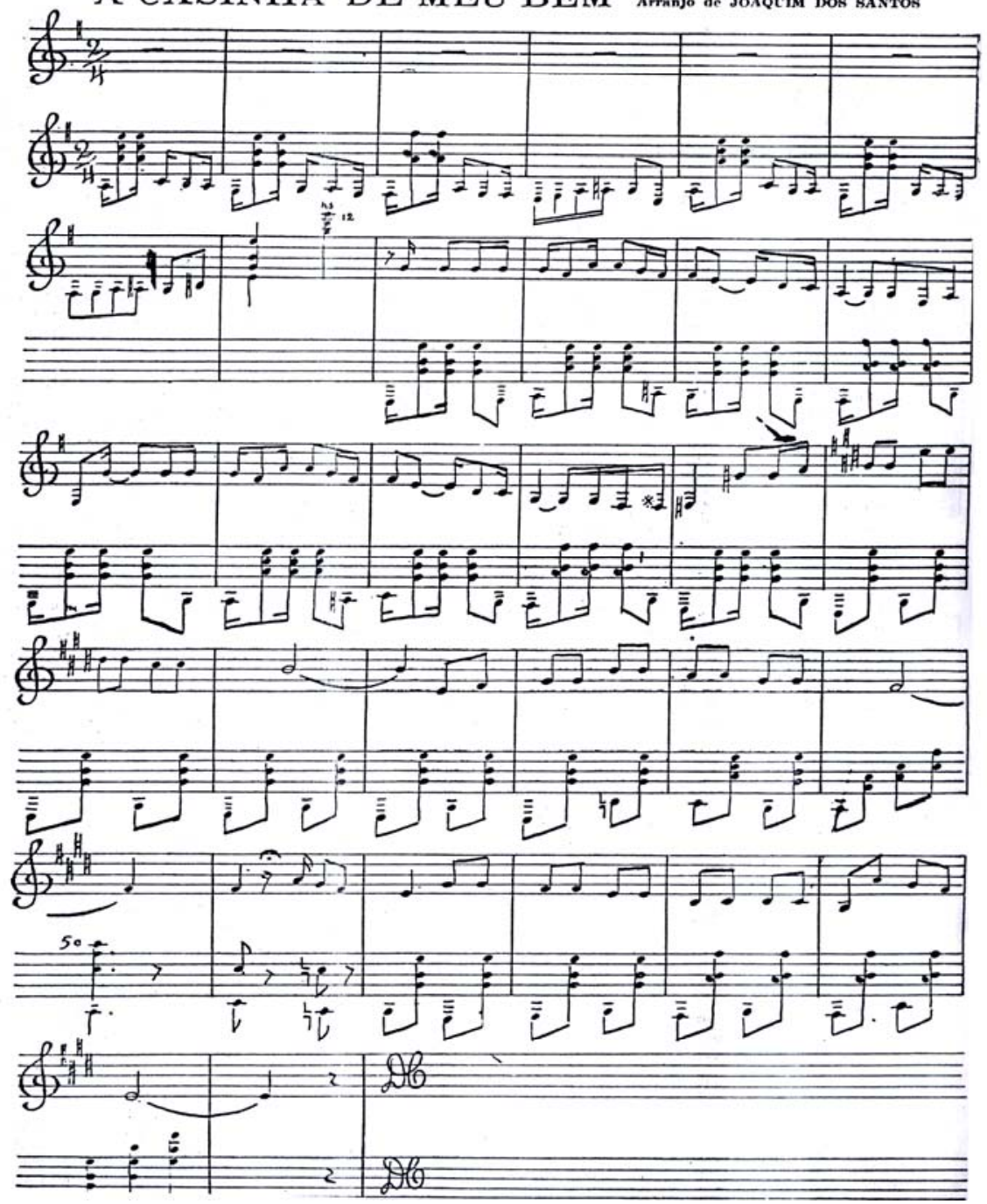

Extrato de partitura 8. Arranjo para violão e voz de Quincas Laranjeiras, para a música Casinha meu Bem, publicado na revista O Violão, 1929. 
Satiro Bilhar ( 1860 - 1927) nasceu no Ceará, viveu no Rio de Janeiro e foi telegrafista-chefe da Estrada de Ferro Central do Brasil.

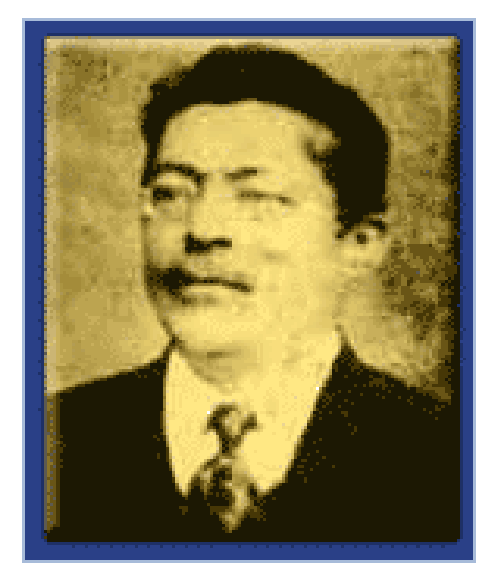

Figura 10. Violonista e compositor Satiro Bilhar.

Querido no meio musical, Villa-Lobos compôs o terceiro movimento das Bachianas Brasileiras $n^{\circ}$ 1, a Fuga/Conversa - à maneira de Sátiro Bilhar, e dizia: "Não importa o que Sátiro toca, mas sim como ele toca" ${ }^{18}$. É possível que Ernesto Nazareth (1863-1934) tenha composto o tango Tenebroso em sua homenagem.

Bilhar causava admiração por sua capacidade de improvisar, em sucessão de acordes, enquanto afinava o violão ${ }^{19}$.

Uma das poucas obras que chegaram até nós é a polca Tira Poeira ${ }^{20}$, gravada por Jacob do Bandolim ${ }^{21}$. Foi parceiro de Catulo da Paixão Cearense em pelo menos duas composições: Gosto de ti, porque gosto e As ondas são anjos que dormem no mar.

\footnotetext{
${ }^{18}$ In: CARVALHO, Hermínio Bello de. Mudando de Conversa. 1. ed. São Paulo: Ed. Martins Fontes, 1986, p. 105.

${ }^{19}$ ENCICLOPÉDIA DA MÚSICA BRASILEIRA: popular, erudita e folclórica. 2. ed. São Paulo: Art Editora: Publifolha, 1988, p.97.

20 In: op.cit. Cadernos do Choro, v.2, p.94.

${ }^{21}$ A primeira gravação de Jacob do Bandolim [Jacob Pick Bittencourt] (1918 - 1969) da música Tira Poeira aparece no disco de 78 rpm, 801565. Rio de Janeiro: RVA Victor, mar. 1956. Ouvir cd em anexo, faixa 5.
} 


\section{Tira Poeira}

polca

Satyro Bilhar

adaptação: Mauricio Carrilho
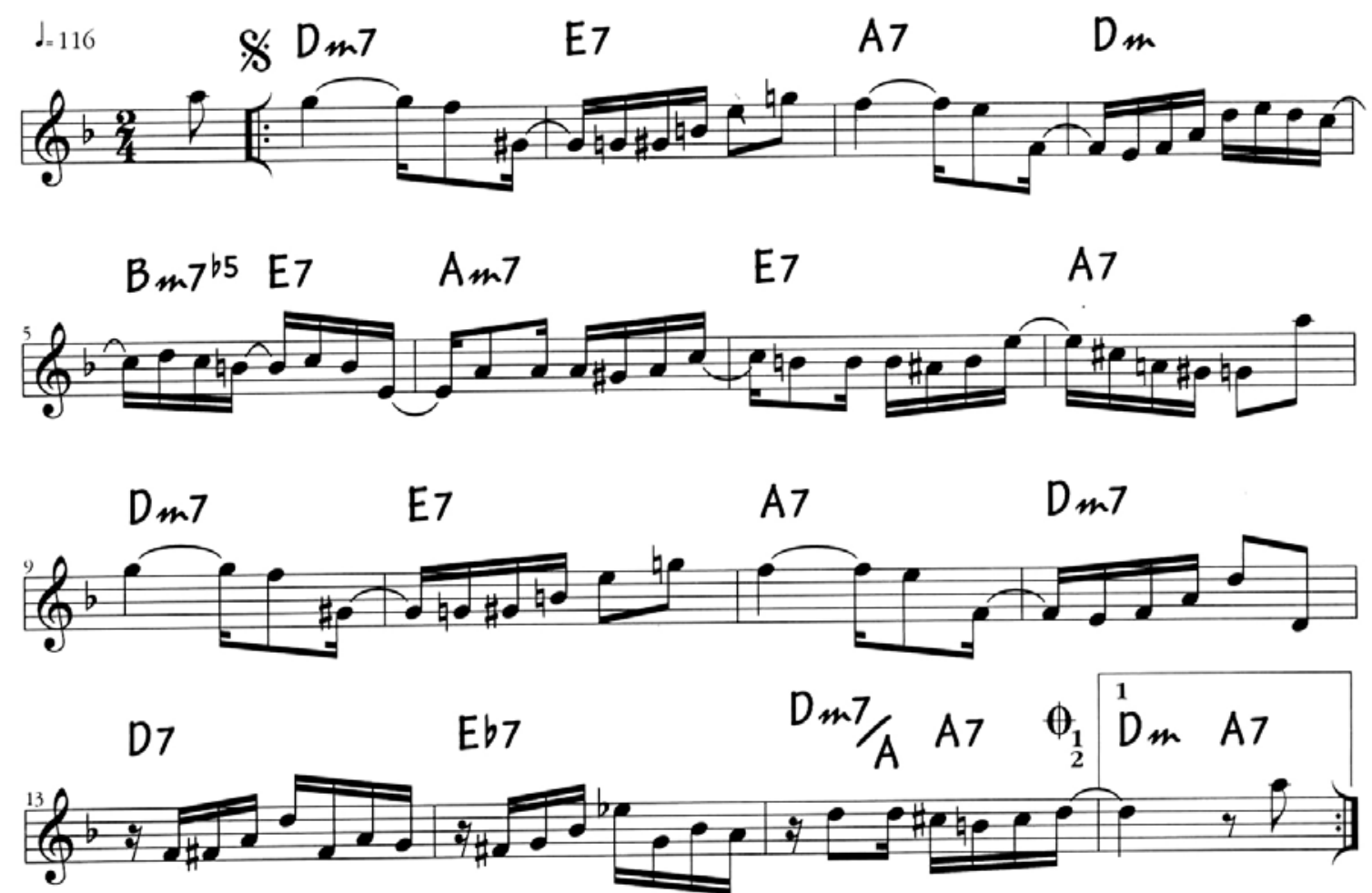

Extrato de partitura 9. Tira poeira, do compositor Satiro Bilhar, em adaptação de Maurício Carrilho.

A musicóloga Ermelinda Paz nos relata uma sui generis comemoração no dia 07 de Setembro de 1903:

A música popular brasileira homenageava os feitos gloriosos de Santos Dumont, com uma serenata gloriosa:

O grupo numeroso reunia os mais representativos músicos boêmios da época e, afora o cançonetista 
Eduardo das Neves, que o 'capitaneava', contava com Villa-Lobos, tocando ocarina, Sátiro Bilhar e Quincas Laranjeira, os dois dedilhando o violão ${ }^{22}$.

\subsection{Panorama Violonístico na época de Othon Salleiro}

Lembramos que não seria exagero tratar o panorama do violão no Rio de Janeiro como sendo a própria história do violão brasileiro, uma vez que foi para a então capital do país que se dirigiram os violonistas de todo país em busca de trabalho e reconhecimento.

O violão brasileiro é um capítulo a parte na história do instrumento. Desenvolveu-se por aqui uma maneira particular de executá-lo. Podemos reconhecer duas vertentes no violão brasileiro: o acompanhante e o solista.

O violão acompanhante teve origem nas modinhas e lundus, conforme vimos nos primeiros capítulos. Na tradição do choro, ao lado de Satiro Bilhar, podemos citar os seguintes nomes que ficaram conhecidos pela habilidade de acompanhar melodias ao violão: Ernesto J oaquim Maria dos Santos (1890 - 1974) conhecido como Donga, Artur Nascimento (1886 - 1957) conhecido como Tute, que foi o iniciador da tradição do violão de sete cordas, Horondino J osé da Silva (1918 - 2006) conhecido como Dino 7 Cordas e Jaime Florence (1909 - 1982), conhecido como Meira.

\footnotetext{
${ }^{22}$ EFEGÊ, J ota. Figuras e coisas da música popular brasileira. V.2, p.140-141. Apud PAZ, Ermelinda A. Villa-Lobos e a Música Popular Brasileira: Uma Visão sem preconceito. Rio de Janeiro: E.A. Paz, 2004, p. 89.
} 
Por outro lado, a vertente instrumental do violão, que é o foco de nossa pesquisa, é formada por músicos que passaram a compor solos para o instrumento, embora alguns fossem eventualmente acompanhadores: Quincas Laranjeiras, Levino da Conceição, Isaías Sávio, J oão Pernambuco, Dilermando Reis, Laurindo de Almeida (1917-1995), Aníbal Augusto Sardinha (1915 - 1955) conhecido como Garoto, Nicanor Teixeira, Othon Salleiro e o próprio Villa-Lobos. As visitas de Josefina Robledo e Agustin Barrios, conforme já vimos, foram decisivas para o desenvolvimento do violão instrumental brasileiro, sendo este último o violonista que mais inspirou Othon Salleiro.

Dois nomes fundamentais para a formação do violão instrumental brasileiro - neste período de efervescência do instrumento no Rio de Janeiro - que exerceram influência na obra de Salleiro foram J oão Pernambuco e Dilermando Reis.

J oão Pernambuco (1883-1947) ou J oão Teixeira Guimarães nasceu em Pernambuco, na cidade de Jatobá. Foi para o Rio de Janeiro em 1904 e trabalhou como ferreiro em casas de fundição, quando começou a freqüentar as reuniões musicais no centro da cidade e chamou a atenção pelo seu talento no violão ${ }^{23}$. Mudou-se para a uma pensão na Rua Riachuelo, onde moravam Pixinguinha e Donga, visitados sempre por Catulo da Paixão Cearense.

Dois anos depois, criou o grupo Caxangá, com sete integrantes. O conjunto chegou a aglomerar dezenove componentes, incluindo Quincas 
Laranjeiras, Pixinguinha e Donga, fazendo sucesso e tocando vários tipos de música, principalmente sertaneja.

O grupo acabou quando Pixinguinha e Donga criaram Os Oito Batutas, formado com metade dos integrantes do Caxangá, inclusive João Pernambuco. Uma das funções do grupo era coletar temas folclóricos nas viagens pelo Brasil.

A influência da obra de João Pernambuco se mantém viva ainda hoje na prática da música instrumental popular, notadamente no choro.

Mencionamos alguns destaques como Interrogando, executada e registrada por solistas de várias gerações, Sonho de Magia, que deve ter inspirado os primeiros compassos de Prelúdio $n^{\circ} 5$ para Violão, de VillaLobos: 


\section{SONHO DE MAGIA VALSA}

revisão e digitação de

Turibio Santos

JOÃO TEIXEIRA GUIMARÃES

(Joåo Pernambuco) - Rio - 1920
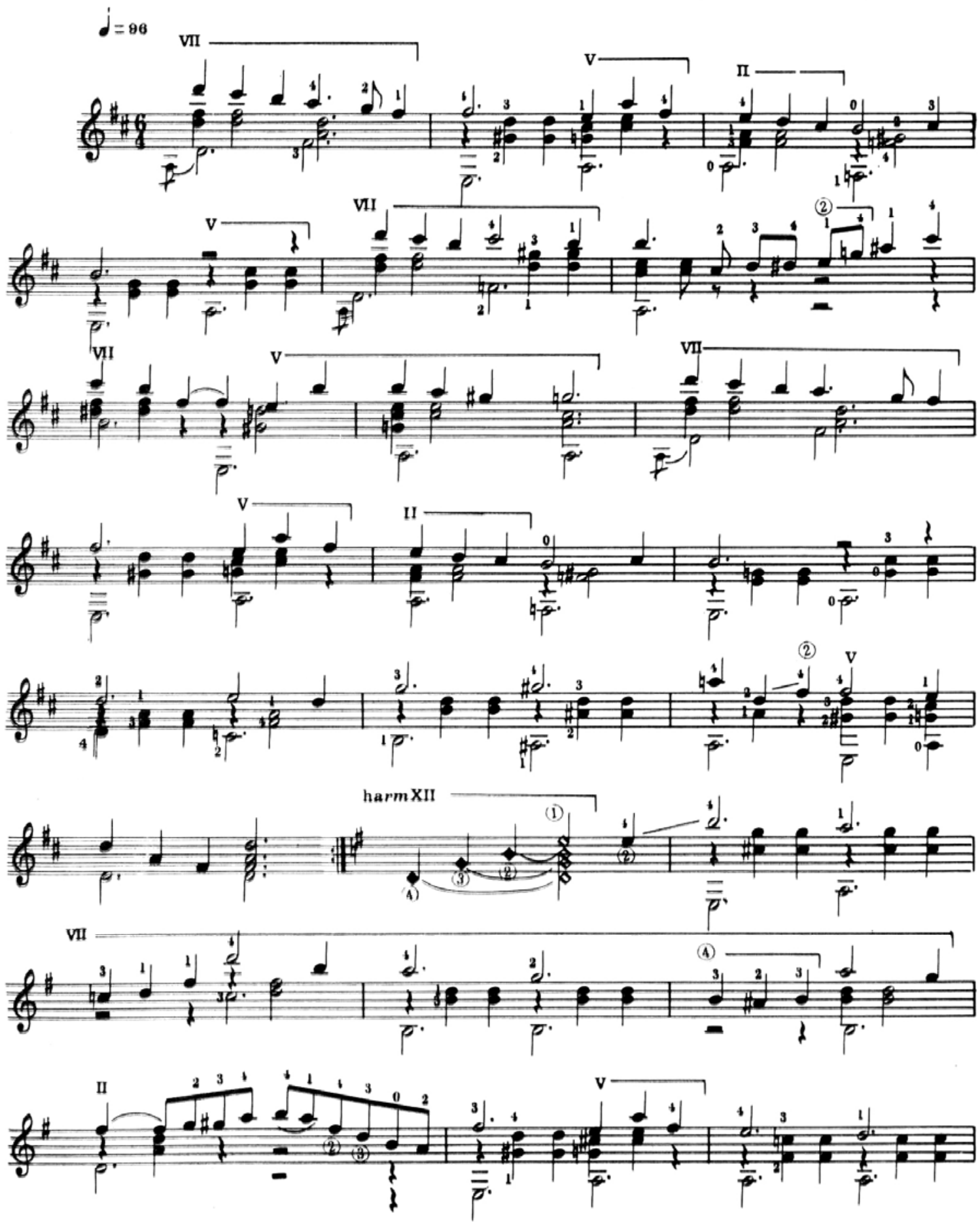

(1) Copyright 1978 by RICORDI BRASILEIRA S.A.E.C. - Sao Paulo (Brasil) All rights reserved - International copyright secured - Printed in Brazil Todos os direitos săo reservados

RB - 0207

Extrato de Partitura 10. Valsa Sonho de Magia, autoria do violonista J oão Pernambuco. 


\section{PRÉLUDE No 5}

Pour Guitare

H. VILLA - LOBOS

(Rio, 1940).
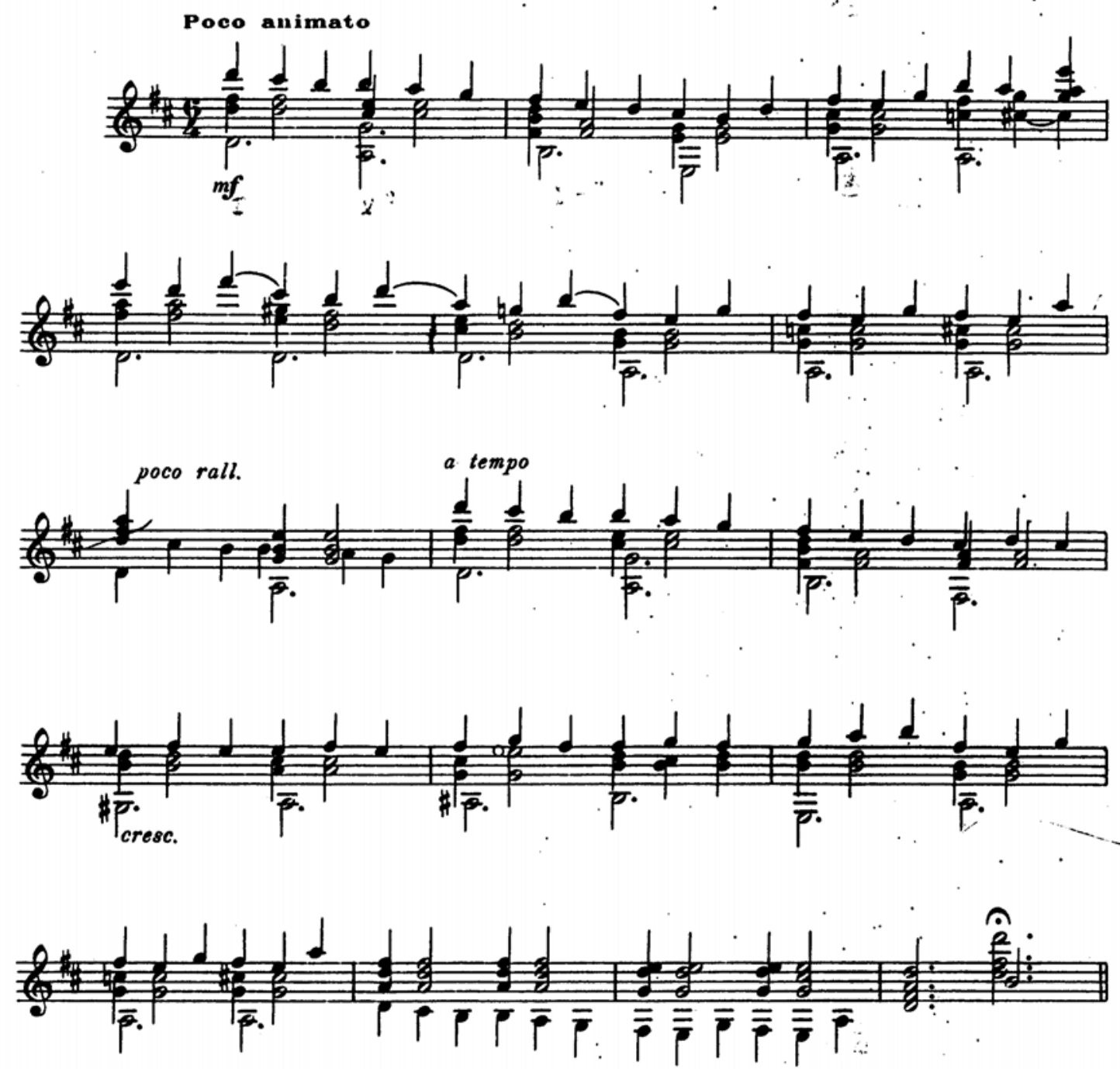

Copyright 1984 by

EDITIONS MAX ESCHIG

48 rue de Rome, Paris 8 e

M.E. 6735

Tous droity dienteution publigue de reproduction it diarrangements mervest pour tous pays.

Extrato de Partitura 11. Prelúdio $n^{\circ} 5$ de Heitor Villa-Lobos. 
O uso de seqüências de acordes diminutos e das campanellas são recursos recorrentes na obra de João Pernambuco, e aparecem de maneira sistemática também na obra de Othon Salleiro. Podemos observar o uso destes procedimentos no exemplo abaixo, na música Brasileirinho, uma espécie de estudo em arpejos:

\section{Brasileirinho}
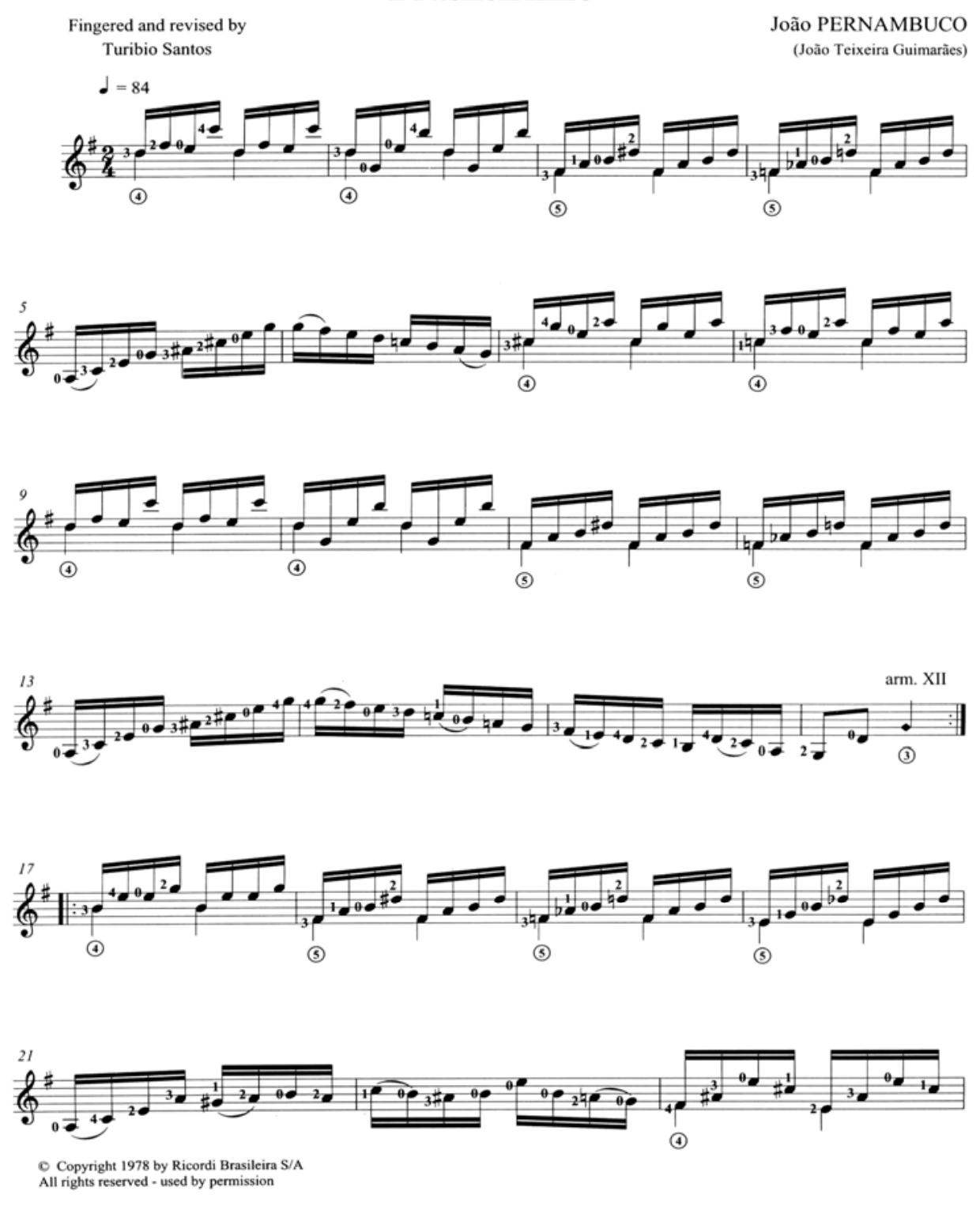

Extrato de Partitura 12. Brasileirinho, Composição de J oão Pernambuco. 
Sobre J oão Pernambuco, Villa-Lobos teria dito a Hermínio Bello de Carvalho 24: "Bach não se envergonharia de assinar seus estudos", opinião um tanto apaixonada, mas que nos dá uma idéia da admiração que VillaLobos nutria pelo amigo violonista.

A música de João Pernambuco abriu novos paradigmas de composição para o violão, ampliando formas de desenvolver melodias a partir de harmonias, com dedilhados idiomáticos do instrumento.

Pernambuco conviveu com Othon Salleiro e desta amizade teria restado uma parceira, Sonhando na Rede ${ }^{25}$, como veremos mais detalhadamente no quarto capítulo.

Em 1934, Villa-Lobos o convidou para ser contínuo na Superintendência de Educação Musical e Artística (Sema), onde trabalhou até sua morte, em $1947^{26}$.

A Associação Brasileira de Violão fez um concerto em homenagem a João Pernambuco, em 1957, onde Othon Salleiro executou Gritos D'alma, Reboliço e Pó de Mico, conforme observamos no programa abaixo:

\footnotetext{
${ }^{24}$ In Mudando de Conversa, p. 107.

${ }^{25}$ Ver detalhes no capítulo 4, em 4.2.3.2, p. 133

${ }^{26}$ PAZ, Hermelinda A. Villa-Lobos e a Música Popular Brasileira: Uma Visão sem Preconceito. Rio de Janeiro: E. A. PAZ, 2004, p.80.
} 
associaçảo brasileira do violào

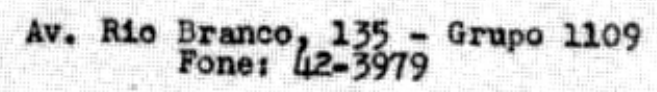

BOLSTIM Ne 14

QUTURRO -1957

HOMENÁGEM PÓSTUMA A JOZO PERNAMBUCO B SUA OBRA

ABERTURA

ALMIRANTB (a malor "patente" do rádio) apresentando un retros pecto da vida e da obra de Joá Pernambuco

18 PARTE

WALTBR BRANCO

CHORO am ré menor

Mnioso

LAhBNTO

OROMAR TERRA

SENTINDO

SONS DB CARRILHOBS

1

BUCLIDBS LBMOS

LAORIKAS

OTHON SALLEIRO

GRITOS D'AUMA

RBBOLICCO

PO DB Níco

26 PARTB

NICANOR TEIXEIRA

INTERROG ANDO - jôngo DENGOSO

MILTOM GARCIA

VALSA $\operatorname{~lá~}$

SEMPRB-VIVA

SONHO DB MAOTA

GRAONA

SOLON AYALA ............ RBCORDANDO MINHA TBRRA BRASILBIRINHO

\section{BNCBRRAMBNTO}

JACOB (o malor "bandolim" brasileiro) em,SURPRBSSAS,.. que nos traxão de volt ta o próprio homenageado.

para o mesmo nossos agradecimentos.

Local : A C M - rua da Lapa,

D1a $31 / 10 / 57$ - as 21 horas.

Figura 11: Programa do concerto em homenagem a J oão Pernambuco, realizado pela Associação Brasileira de Violão, Rio de Janeiro, 1957. 
Dilermando Reis (1917-1977) foi o primeiro violonista a divulgar em gravações e concertos a obra de J oão Pernambuco. Começou a estudar violão com o pai, o violonista Francisco Reis, ainda na infância. Em 1931, depois de assistir a um concerto de Levino da Conceição em Guaratinguetá, tornou-se seu aluno e seu acompanhante.

Em 1933 chegam ao Rio de Janeiro, e em 1934 Levino da Conceição, a pretexto de ir a Campos, deixou pagos 15 dias de hotel para o jovem violonista e voltou à cidade somente dois anos depois. Sozinho na cidade, ele procurou auxílio de João Pernambuco, que o acolheu.

Um dos mais célebres violonistas populares brasileiros, atuou como instrumentista, professor, compositor e arranjador. Deixou uma obra numerosa composta de guarânias, boleros, toadas, maxixes, sambascanção e principalmente de valsas e choros. Sua obra é ainda hoje a mais executada e gravada entre os violonistas populares. Devemos ressaltar que a obra de Dilermando Reis tem tido aceitação no mercado internacional, gerando publicações e gravações, como o recente registro do violonista escocês David Russel (1958) ${ }^{27}$.

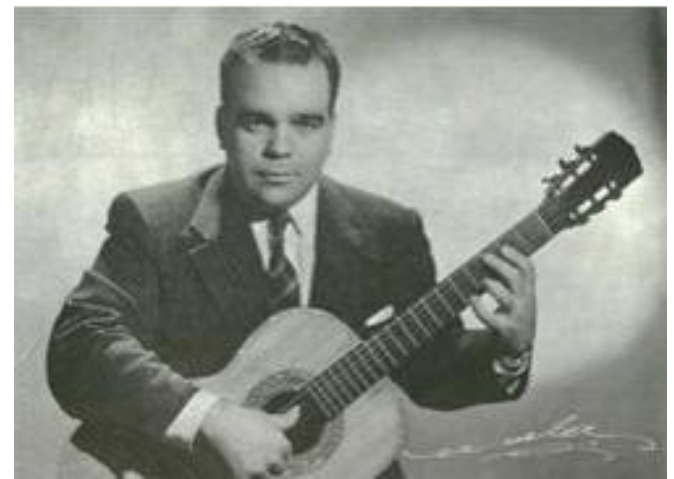

Figura 12. O compositor e violonista Dilermando Reis.

${ }^{27}$ RUSSELL, David. Aire Latino: Latin American Music for Guitar. Ohio: Telarc. CD-80612, 2004. 
Em 1935, lecionou na loja A Guitarra de Prata e começou a trabalhar na Rádio Guanabara. Comandou o Variedades Esso, na Rádio Transmissora - hoje Radio Globo, com um programa de violão, diariamente. Como já naquela época não era possível sobreviver apenas de solos de violão, continuou como acompanhador em regionais, como faziam todos os grandes violonistas da época, entre eles Rogério Guimarães (1900 - 1980), Aníbal Augusto Sardinha (1915 - 1955) ou Garoto, José Menezes (1921) e Laurindo de Almeida (1917 - 1995). Em 1956, Dilermando Reis, por interferência do recém-empossado presidente J uscelino Kubitschek, assinou contrato com a Rádio Nacional, para dirigir o programa Sua Majestade, o Violão. O programa tinha como vinheta a mazurca Adelita, de Francisco Tárrega e se manteve em atividade até 1969.

Magoado é provavelmente o mais conhecido e mais executado de seus choros. 


\section{MAGOADO}

CHORO

Dedicado ao meu mano

Erasto Reis

DILERMANDO REIS
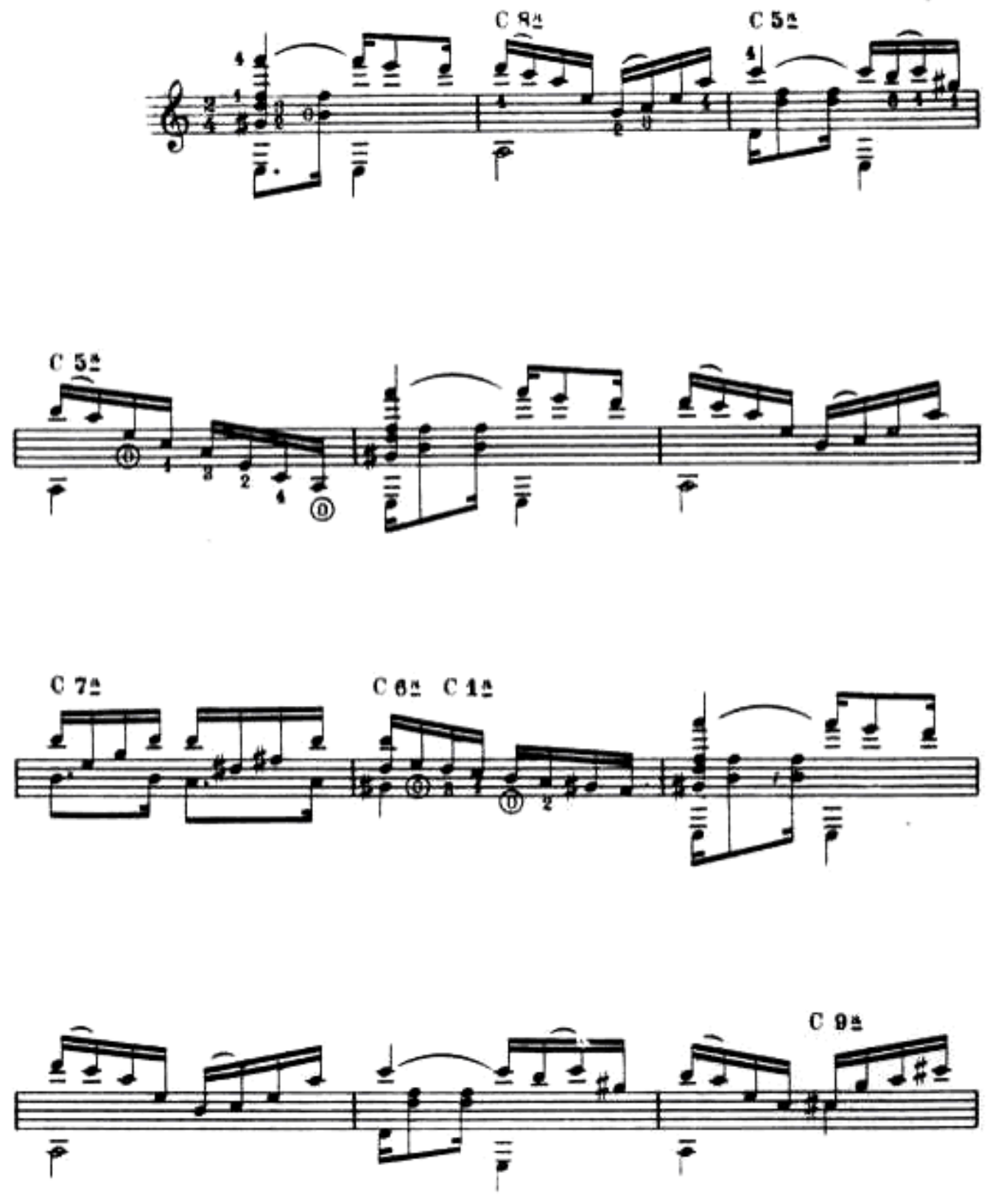

Extrato de Partitura 13. Magoado, choro de Dilermando Reis. Editora Musical Brasileira LTDA. Rio de Janeiro, 1954. 
Como professor, ensinou a grandes violonistas dentre os quais Darci Vila Verde e Nicanor Teixeira. Foi também professor de Maristela Kubitscheck, filha do presidente Juscelino Kubitscheck, de quem foi grande amigo e parceiro de serenatas.

O grande sucesso de Dilermando Reis acabou ofuscando muitos violonistas contemporâneos dele. Vários destes compositores passaram despercebidos como foi o caso de Othon Salleiro, Homero Alvarez, José Augusto de Freitas e Mozart Bicalho.

O relacionamento com Othon Salleiro embora cordial não foi amistoso, como veremos adiante. Diz-se que Dilermando Reis teria composto o choro Dr. Sabe Tudo como uma forma de satirizar Othon Salleiro que possuía educação formal muito superior a média dos violonistas da época, o que causava certo desconforto para seus contemporâneos.

A cidade de Guaratinguetá mantém, anualmente desde 1996, um festival de violão em homenagem a Dilermando Reis, onde atuam importantes nomes do violão brasileiro e internacional. Edmauro de Oliveira, ex-aluno do Departamento da Eca/Usp e o Sr.Hermínio Pedromônico são os idealizadores do Festival.

É esta enorme variedade de estilos que compõe a linguagem instrumental de Othon Salleiro. Como veremos no próximo capítulo, sua obra não é composta somente das influências do meio musical popular urbano ao qual estava inserida. São composições que revelam a síntese do universo idiomático latino-americano de Agustin Barrios; as novas 
possibilidades de textura, harmonia e extensão dos recursos idiomáticos do violão de Villa-Lobos; o regionalismo rítmico e temático de J oão Pernambuco e a descoberta do rico universo técnico e musical do violão clássico que se descortinava no Rio de Janeiro com a presença de violonistas como Narciso Yepes, Josefina Robledo, Maria Luisa Anido, Isaías Sávio e Andres Segovia. 


\section{Othon Salleiro (1910 - 1999)}

\subsection{Othon Salleiro - Violonista e compositor}

No livro Música Popular Brasileira Estilizada de autoria de Henrique Pedrosa ${ }^{1}$, encontramos a seguinte constatação:

(...) Em termos de violão a maior barbaridade é o esquecimento e quase total descaso quanto a Othon Salleiro. Perguntem subitamente a um violonista erudito como J oão Pedro Borges ${ }^{2}$ quem é o Ernesto Nazareth do violão atual. Othon Salleiro será a resposta. Um dos mais interessantes e originais violonistas brasileiros.

Por outro lado, Genésio Nogueira em sua biografia: Dilermando Reis: Sua Majestade o Violão, nota:

Se hoje o Brasil não conhece como deveria o grande Othon Salleiro, o único culpado foi ele mesmo, por não se preocupar com a divulgação de seu talento, comportando-se como amador. No meu entender, trata-se de um dos Tmaiores compositores para violão de nosso país. Suas composições são cheias de surpresas, e de difícil execução. Tocar Othon Salleiro significa conhecer violão. É lamentável que suas obras não tenham sido editadas.

\footnotetext{
${ }^{1}$ PEDROSA, Henrique. Música popular brasileira estilizada. 1. ed. Rio de Janeiro: Editora Universidade Santa Úrsula, 1988, p. 143.

${ }^{2}$ J oão Pedro Borges, nasceu no Maranhão. Iniciou seus estudos de violão clássico com o professor maranhense Luís Almeida. Em 1970, transferiu-se para o Rio de Janeiro, onde estudou com Jodacil Damaceno, Ian Guest e Turíbio Santos. Com este último desenvolveu uma série de projetos pedagógicos e registros fonográficos.
} 
Sobre a importância que dava às suas obras, Nicanor Teixeira lembra que era muito "desapegado", talvez pelo fato de ter outra forma de sobrevivência que não a música:

São quatro músicas que ele editou, ele disse para o Seu Gustavo, o dono da Casa Wehrs ${ }^{3}$ : Eu não quero direito não, me dá tanto e tá bom. E deixou lá, não pediu os direitos.

Em 1965, na Revista Violão e Mestres ${ }^{4}$, em artigo sobre a Associação Brasileira de Violão, o nome de Salleiro aparece algumas vezes: “Como sócio fundador da ABV, juntamente com Samuel Babo, Oswaldo Soares, Milton Rodrigues de Araújo, Antonio Rebello, Osmar Abreu".

Aparece também no próximo parágrafo:

MUSICISTAS QUE SE APRESENTARAM EM SUAS REUNIÕES MENSAIS, entre eles: Othon Saleiro, (grifo nosso) Milton Rodrigues, Milton Botelho, Alzidio Cruz, Sólon Ayala, Antonio Rebelo, Waltel Branco, Jodacil Damasceno, Cecy Mascarenhas, Turíbio Santos, Luiz Alan, Edgard de Oliveira, Norberto Macedo, Eucides Lemos, Ivo Cordeiro, Darcy Villa-Verde, Nicanor Teixeira, Oromar Terra, Helena Ribeiro, Leo Afonso de Morais Soares, Raul Santiago.

E aparece ainda em:

\footnotetext{
${ }^{3}$ Extinta casa especializada em música, da década de 60, no Rio de Janeiro, situada na Cinelândia, editava algumas partituras, sem numeração e nem data de edição. São, em realidade, seis as peças editadas pela Casa Wehrs.

${ }^{4}$ Violão e Mestres. São Paulo: Giannini, n.4, p.25, 1965.
} 
CONCERTISTAS FAMOSOS APRESENTADOS PELA ABV:

Abel Fleury, Maria Luisa Anido, Isaias Sávio, Carlos

Collet, Carlos Carrion, Narciso Yepes, Oscar Cárceres,

Othon Saleiro (grifo nosso), Antonio Carlos Barbosa Lima, Griselda Ponce de Leon, Walter Branco e Avena de Castro (cítara).

Em 1956, em Carta ao poeta Manuel Bandeira ${ }^{5}$, Hermínio Bello de Carvalho, ao contestar um ensaio do poeta, A Literatura do Violão, publicado na mesma revista ${ }^{6}$, cita Othon Salleiro, que figura entre outros tantos violonistas que legitimariam a defesa do violão como um instrumento tão rico e tão nobre quanto qualquer outro ${ }^{7}$. Carvalho ainda cita Othon Salleiro em um artigo sobre o violão brasileiro ${ }^{8}$. Lembrando da pecha comumente atribuída ao violão, instrumento de vagabundo, malandro, excetua Othon Salleiro:

(...) Nesse grupo não se incluía Othon Salleiro, também discípulo de Quincas Laranjeiras, psiquiatra que gravou um imperdível LP há mais de 10 anos, hoje raridade fonográfica, freqüentador também do Bandolim de Ouro.

Na verdade, o referido ensaio de Manuel Bandeira havia sido originalmente publicado pela revista Ariel (1924) e republicado por Lúcio Rangel na Revista da Música Popular sem nenhuma referência sobre a data original do ensaio, o que gerou a resposta de Carvalho, que naquela

\footnotetext{
${ }^{5}$ Carta publicada na Revista da Música Popular. Rio de Janeiro. N 14, p.5-12, 1956.

${ }^{6}$ Este ensaio foi originalmente publicado pela revista Ariel (1924) e republicado por Lúcio Rangel na Revista da Música Popular, em 1956 (ex. 12, abril, p.8).

${ }^{7}$ Respondendo a Manuel Bandeira: (...) Que sua técnica é ingratíssima (do violão), o tempo perdido em adquirir um mecanismo sofrível será bem mais compensador aplicado a um outro instrumento mais rico - e mais nobre.

${ }^{8}$ Em Mudando de Conversa. 1986, p. 109.
} 
altura desconhecia o fato do referido ensaio ter sido escrito há trinta e dois anos e, portanto, naturalmente desatualizado ${ }^{9}$.

Ronoel Simões ${ }^{10}$ conheceu Othon Salleiro em 1945:

Salleiro era muito importante. Coisas muito bonitas, ele tocava muito bem. Ele era um violonista de muitas possibilidades, tocava um repertório muito difícil. Tem coisas muito importantes, ele tocava Allegro Caprichoso, muito difícil, bonita, dele mesmo. Também o Repinicado de Viola, ele tocava com muita graça, composições muito bonitas. Ele tocava também uma coisa argentina, Chimarrita, tudo obra dele. Ele tocava muito bem, e fora do violão ele era muito inteligente também, era médico, psiquiatra. Discutia sobre o violão do mundo todo.

Simões, em artigo sobre o violão no Rio de Janeiro (Violão e Mestres, 1965, $\mathrm{n}^{\circ} 4$ ), cita também Othon Salleiro em sua grande lista de violonistas que contribuíram para a evolução do instrumento na cidade.

Como foi possível observar acima, além de conhecido no círculo violonístico, Salleiro era também respeitado. Conciliando sua vida de psiquiatra com a de músico amador, participou ativamente do movimento violonístico carioca.

Levantam-se algumas questões: Como teria a obra de Salleiro ficado praticamente esquecida nestes anos? Porque, circulando nos meios urbanos cariocas, de roda em roda de choro,

\footnotetext{
${ }^{9}$ Os dois textos na íntegra podem ser encontrados no livro: COLEÇÃO REVISTA DA MÚSICA POPULAR. Edição fac-símile 1954-1956. Rio de Janeiro: Funarte: Bem-te-vi Produções Literárias, 2006, p.620-622 e 728-731. Maiores detalhes sobre os dois textos: PAVAN, Alexandre. O Timoneiro. Rio de Janeiro: Casa da Palavra, 2006, p.46.

${ }^{10}$ Ronoel Simões, paulista, nascido em 1921, violonista, pesquisador e colecionador. Possui o maior acervo de partituras e gravações de violão do Brasil.
} 
teria Salleiro composto somente obras para violão solo? E mais: se a vivência de Salleiro foi quase que inteiramente urbana, como explicar o caráter sertanejo ou regional em muitas de suas obras? Como justificar a utilização de recursos idiomáticos que não haviam sido utilizados entre seus pares e que somente encontram paralelo no chamado violão clássico? Através de seu perfil biográfico, vamos tentar responder às perguntas acima.

Conforme vimos, Othon Sivaldo Vaz Salleiro nasceu na cidade do Rio de Janeiro em 1910. Aos dezesseis anos tornou-se aluno de Quincas Laranjeiras e sua vocação musical começou a incomodar seus pais, que desejavam vê-lo formado em medicina. Foi aluno do violonista Gustavo Ribeiro. Aos 19 anos começaram as apresentações, "para alguns era o melhor violonista clássico do Rio de Janeiro" (NOGUEIRA, 2000).

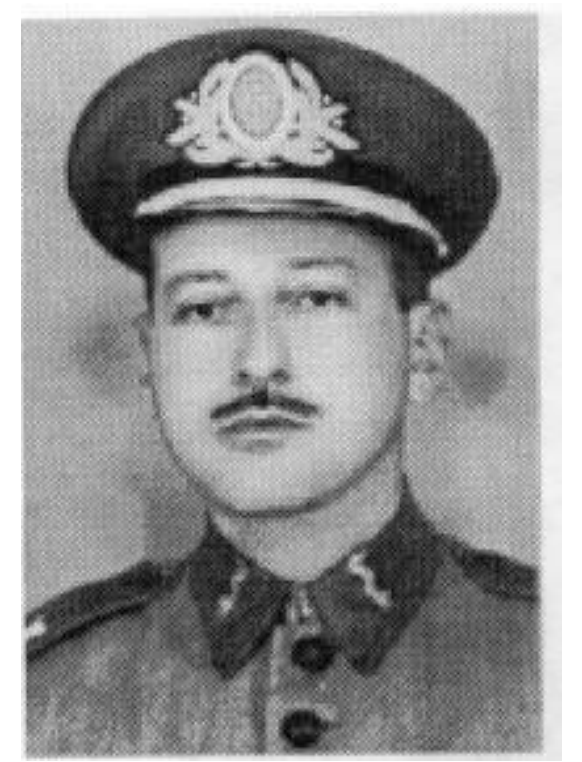

Figura 13. Othon Salleiro - 2o Tenente do Exército

Foi nesta época também que, segundo relatava o próprio Salleiro, teria recebido uma herança de seu padrinho, o Sr. Peixoto, que seria dono 
do Bairro do Peixoto (Copacabana), então uma chácara. Othon Salleiro teria vendido tudo e ido para Porto Alegre ${ }^{11}$ (NOGUEI RA, 2000). Ali, segundo consta, passou vários anos e teria composto a maior parte de sua obra. Provavelmente o caráter regional de muitas de suas composições possa ser explicado por este período em que residiu no sul do país.

Suas modas de viola, chimarritas e repenicados fogem a temática urbana do choro de então. Outra hipótese é que a utilização de um repertório característico da viola pudesse remeter ao Rio de Janeiro oitocentista. Instrumento trazido pelos portugueses, a viola instalou-se no meio urbano e sofreu sua interiorização somente em meados do século XIX com a introdução do violão na sociedade brasileira, principalmente nas capitais. É provável que Othon Salleiro, nascido na primeira década do século XX, tenha ainda na infância ouvido os resquícios desta tradição.

Abaixo trecho de um artigo da musicóloga Márcia Taborda sobre o referido assunto:

(...) Para concluir, nota-se que desde o início da colonização a viola esteve estreitamente vinculada à sociedade que se formou no Brasil. Foi identificada por viajantes estrangeiros nos mais remotos recantos do território nacional, nas tabas, nas choupanas, nas casas grandes e até mesmo nos palácios governamentais. A partir da metade do século XIX, quando a novidade do violão estava perfeitamente assimilada pela sociedade carioca, a viola assumiu identidade regional,

\footnotetext{
${ }^{11}$ Esta história nos foi relatada também por Nélio Rodrigues, em entrevista realizada em 12/2005.
} 
interiorana, estando a serviço de repertório típico de danças e canções da memória e da tradição oral ${ }^{12}$.

Em outras composições encontramos o sabor nordestino tão em voga na música urbana carioca. Introduzidos por Catulo da Paixão Cearense, J oão da Baiana (1887 - 1974), João Pernambuco, Romualdo Miranda (1887 - 1930) e Luperce Miranda (1904 - 1977), entre tantos outros músicos que chegavam a então capital do país, os ritmos do nortenordeste do país vão delinear a estética da música instrumental brasileira. Salleiro, sendo amigo próximo de J oão Pernambuco e dos irmãos Miranda, foi influenciado por estes ritmos.

Depois da temporada no sul do país, Salleiro volta ao Rio de Janeiro, forma-se pela Faculdade Nacional de Medicina, e mais tarde especializa-se em psiquiatria. Trabalhou como médico psiquiatra no Hospital do Engenho de Dentro, bairro da cidade do Rio de Janeiro, durante quarenta anos.

Conviveu com Quincas Laranjeiras de quem foi aluno, J oão Pernambuco, João da Baiana, Jacob do Bandolim, Dilermando Reis, Pixinguinha e Agustín Barrios. Barrios foi quem mais influenciou Salleiro, passando para este a importância do apuro técnico, a ligação com o folclore da América do Sul e o estilo da linguagem violonística.

Citamos síntese feita pelo violonista Fabio Zanon em programa na Rádio Cultura:

A originalidade e finesse da obra de Salleiro emerge do amálgama perfeito entre a poética da música popular urbana, elementos regionalistas e uma complexidade

\footnotetext{
${ }^{12}$ TABORDA, Márcia. A viola no Rio de Janeiro Oitocentista. Brasiliana: Revista Quadrimestral da Academia Brasileira de Música. dez.2006, p.15-19.
} 
de texturas oriundas do seu detalhado conhecimento do repertório clássico do violão. As lojas de instrumentos eram ponto de encontro entre os músicos no Rio e nelas ele conviveu com João Pernambuco, Pixinguinha, Jacob do Bandolim, mas também com Segovia e Agustin Barrios, que foi sua influência mais evidente como compositor, nas soluções harmônicas inesperadas e na exploração das possibilidades dramáticas do registro agudo do violão ${ }^{13}$.

Abaixo dois extratos, o primeiro do Prelúdio Carioca, de Othon Salleiro e o segundo o Prelúdio da música Catedral de Barrios, onde podemos ver evidenciada a influência que Barrios exerceu sobre a obra de Salleiro:

${ }^{13}$ ZANON. Fabio. In: Violão com Fabio Zanon: Violão Brasileiro. Nossos pioneiros, criadores e intérpretes. Benedito Chaves, Othon Salleiro e José Augusto de Freitas. Programa transmitido pela Rádio Cultura, n.49, São Paulo, nov.2006. 
Revisão Nélio Rodrigues

Tranquill $\quad J=58$
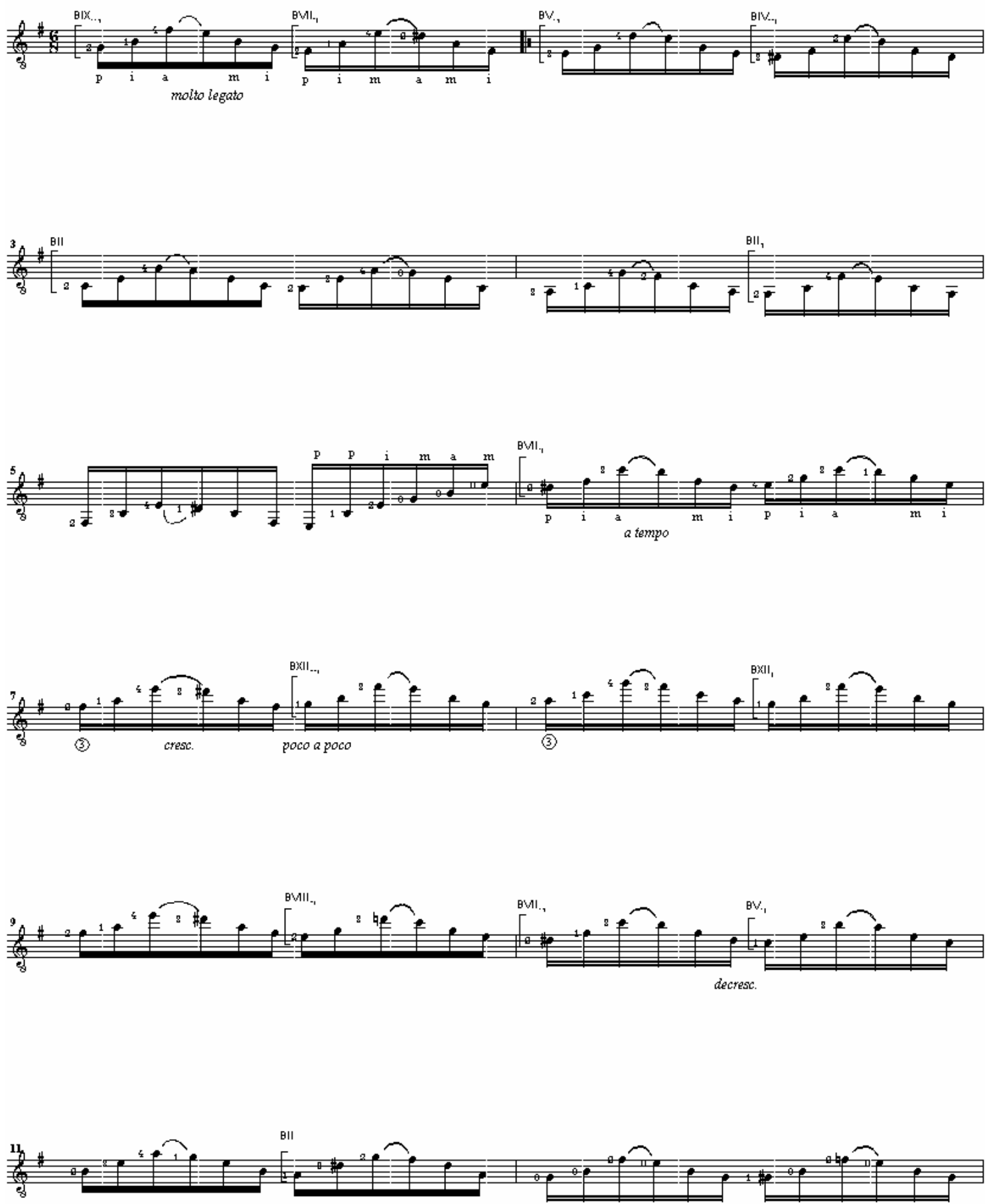

Extrato de Partitura 14. Prelúdio Carioca, música de autoria de Othon Salleiro. 
Revisión de :
Jesús Benites R.

\section{La Catedral}

$$
\text { 大塑堂 }
$$

I Preludio (Saudade)

Agustín Barrios Mangoré

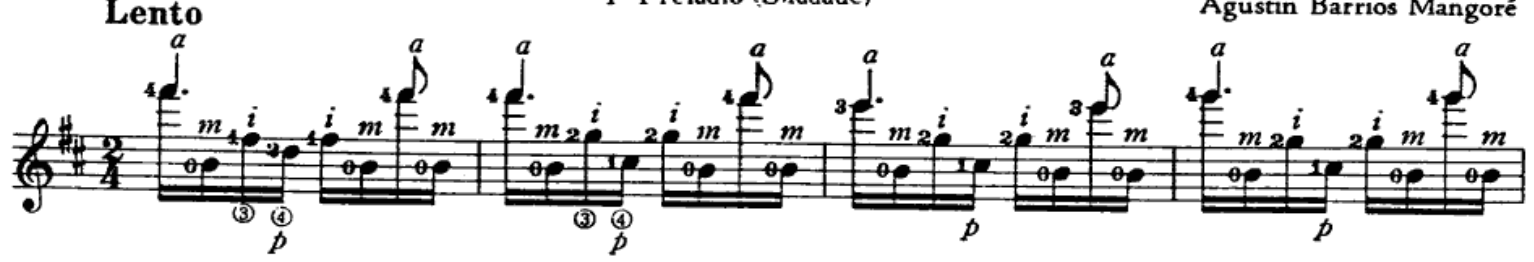

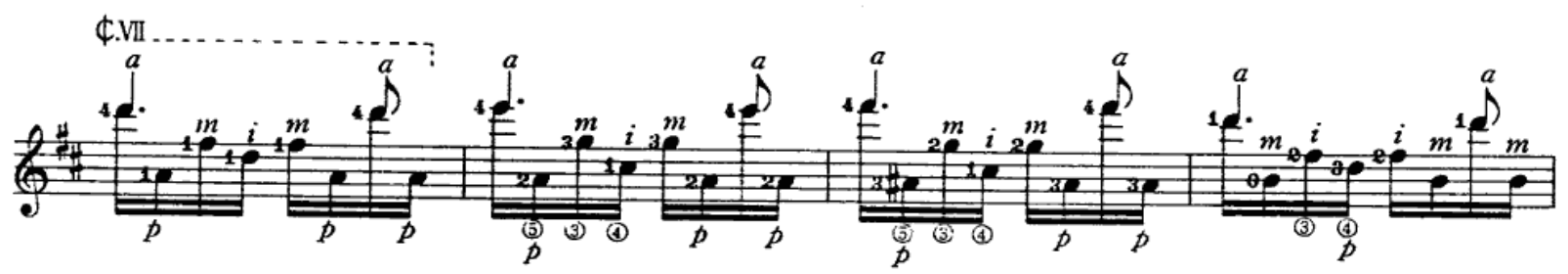
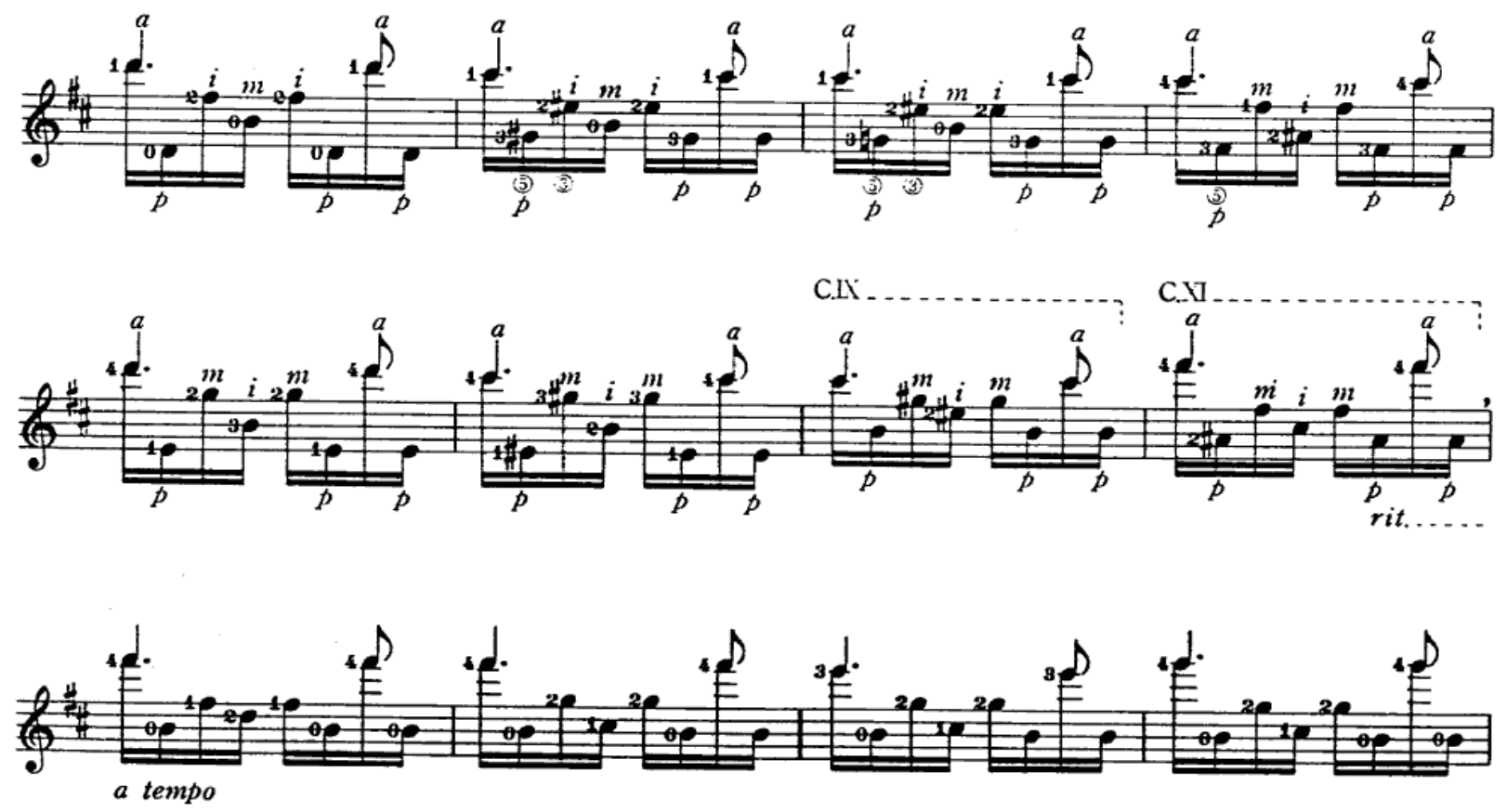

Extrato de Partitura 15. Prelúdio de La Catedral, uma das músicas mais conhecidas do violonista paraguaio Agustin Barrios. 
Compositor inventivo teve como parceiros J oão dos Santos ${ }^{14}$, J oão

Pernambuco e Eduardinho da Piedade. De suas parcerias ${ }^{15}$, restaram três partituras, gentilmente cedidas por Nélio Rodrigues para nossa pesquisa.

Nas partituras não constam assinaturas das parcerias: Sonhando na Rede, com J oão Pernambuco, Choro Seresteiro em parceria com Eduardinho da Piedade e Batuque com J oão dos Santos. Restam os testemunhos de Múcio Carias, Nélio Rodrigues e Nicanor Teixeira, sendo que este último recorda-se somente do Batuque, em parceria com J oão dos Santos ${ }^{16}$. Nélio nos conta sobre as parcerias de Othon Salleiro:

Tem com João Pernambuco, com Eduardinho da Piedade e com J oão dos Santos, mas não está assinado. A com o Eduardinho da Piedade que ninguém sabe quem foi. É uma coisa engraçada, moderna, fácil de escrever, ele me fez pegar, escrever e falou que era uma música que ele havia feito com Eduardinho da Piedade. É uma música bonita. Tem o famoso Batuque do J oão dos Santos que é parceria também. E ele contou, ele me mostrou a batucada que ele fazia, começou no Batuque com o J oão. E tem a parceria com o Pernambuco, que era Sonhando na Rede, que foi escrita pelo Hélcio, balconista da Guitarra de Prata, ele tocava violão, porque para vender violão era bom ter alguém para afinar. O Hélcio ficava vendo os violonistas tocarem, e naquela época, era diferente, não se dividia repertório. Salleiro não dava nada a ninguém, Dilermando não dava nada a ninguém. Eles escondiam as músicas, para preservar o repertório, tinha uma

\footnotetext{
${ }^{14}$ Em Mudando de Conversa, p.107, Hermínio Bello de Carvalho conta sobre João dos Santos: (...) "Bandolim de Ouro", da Rua Uruguaiana, 'ponto' dos artistas da época, onde se encontrava facilmente João dos Santos, compositor bastante divulgado por Dilermando. Ao que se sabe era paulista. Além dos "Batuques $n^{\circ} 1$ e 2 ", conhecem-se também o "Paulista", o "Alma Brasileira". Gostava de escrever choros com modulações inesperadas para 'derrubar' seus companheiros de roda, prática musical da época.

${ }^{15}$ Ver partituras confeccionadas por Nélio Rodrigues, capítulo 4 p.129.

${ }^{16}$ Depoimentos colhidos em entrevistas realizadas para a presente pesquisa, realizadas no Rio de Janeiro, em outubro e novembro de 2005.
} 
porção de macetes, e o Hélcio, ficava vendo eles tocar, ouvia, e ia anotando aos poucos, escondido, debaixo do balcão, foi assim que se preservaram muitas coisas que nós tocamos hoje ${ }^{17}$.

Sobre o referido batuque, Rodrigues relata em outro trecho da entrevista:

E foi no Batuque do J oão que aparece aquele batuque no espelho do violão, é muito bom, para ele é uma coisa que devia ser clara, é difícil de entender, mas fica muito interessante, ao mesmo tempo em que pinça a nota bate com as unhas no braço do violão. (referindose a mão direita) ${ }^{18}$.

Conforme podemos observar no trecho do Batuque de Salleiro, anotado por Nélio Rodrigues ${ }^{19}$ :
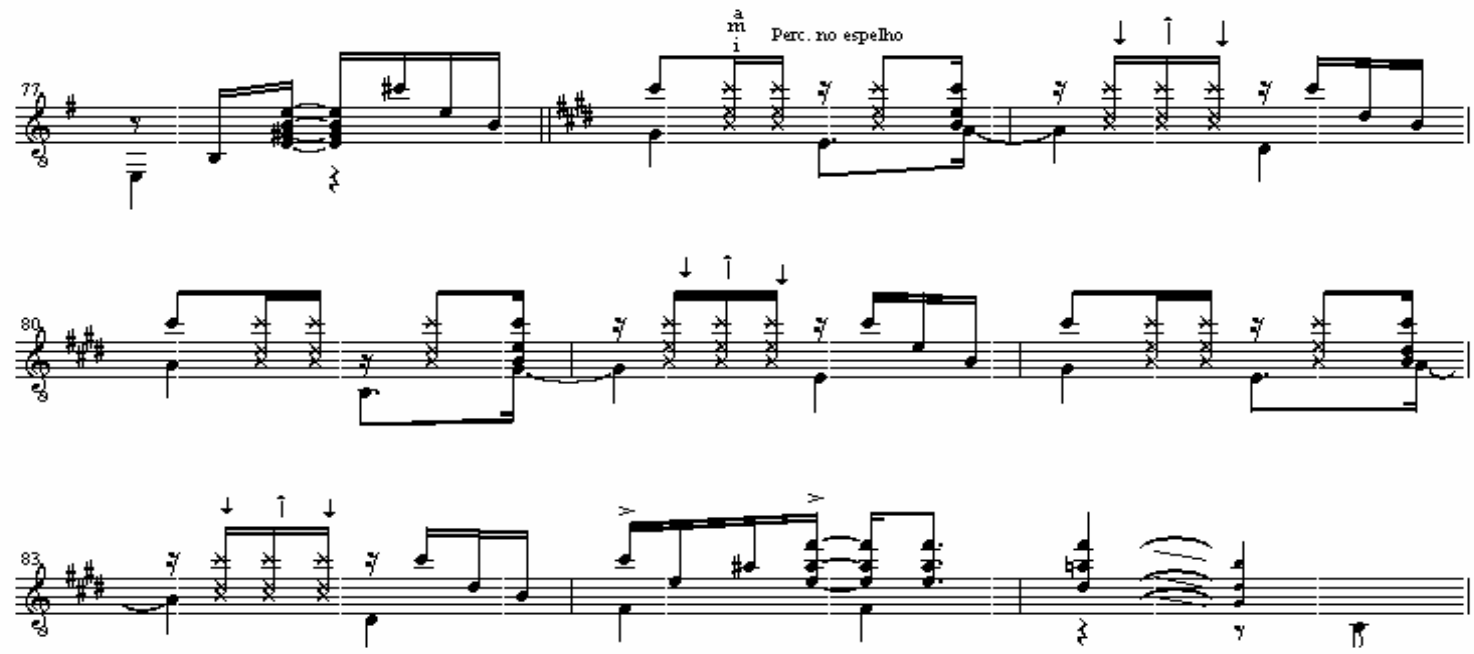

Extrato de Partitura 16. Trecho da música Batuque, de Othon Salleiro.

\footnotetext{
${ }^{17}$ Entrevista concedida por Nélio Rodrigues no Rio de Janeiro, dez. 2005.

18 Idem.

${ }^{19}$ No LP Violão Brasileiro, gravação do compositor que utilizamos para confecção das partituras deste estudo, podemos observar uma variante utilizada pelo compositor, o referido trecho é feito em tâmboras. Ver transcrição em Partituras em 4.2.3.3, p. e ouvir a gravação do compositor, cd anexo, faixa 9.
} 
Sobre as parcerias, Nicanor Teixeira recorda:

Ele me disse que tinha uma parceria com João dos Santos. Um violonista, ótimo, adorava derrubar os outros, ninguém acompanhava ele não, tinha um swing. O Salleiro era muito amigo dele. Ele chegou a me passar este choro, um choro simples. Era um choro simples, mas bonito ${ }^{20}$.

Salleiro freqüentava os saraus da casa de Jacob do Bandolim, eram vizinhos e muito próximos. Salleiro foi padrinho de casamento do amigo bandolinista. Maria Salleiro, viúva do violonista, lembra que tanto Salleiro freqüentava os saraus quanto Jacob do Bandolim ia tocar na casa do casal Salleiro. Tocava acompanhado de outros músicos, Salleiro não acompanhava o amigo bandolinista:

Acompanhavam ele, o Othon preferia ouvir, não tocavam muito junto. Eles tinham estes ciúmes também, quem toca melhor. O Jacob era meio sistemático e o Othon também, tinham aquele orgulho, aquela coisa assim...Queriam silêncio total quando estavam tocando. Não bebiam, Graças a Deus, com aquele temperamento, se o Othon bebesse ninguém agüentava. Othon era muito temperamental, tava tudo bem, de repente, explodia, ele dizia que artista era assim mesmo. Mas era uma pessoa muito boa, atendia de graça, era uma pessoa caritativa. Quanto ele tinha alunos, era muito severo, eu ficava com pena ${ }^{21}$.

\footnotetext{
${ }^{20}$ Entrevista concedida por Nicanor Teixeira, Rio de Janeiro, jul. 2006.

${ }^{21}$ Depoimento colhido em Jacarepaguá, em jul. 2006.
} 
Foi muito admirado pelos violonistas, Nicanor Teixeira diz:

O Salleiro para mim era um cara fantástico, que dividia seu tempo entre a música e a psiquiatria. Ele tinha 18 anos, trancou a medicina para entrar na roda de choro, foi aí que conheceu a turma da pesada, Romualdo Miranda ${ }^{22}$. No tempo das polcas, muito bom.

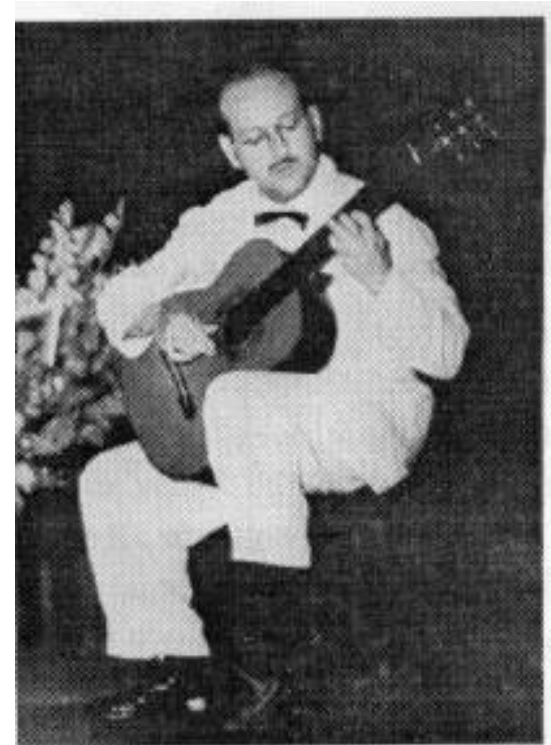

Figura 14. Othon Salleiro.

Além de compositor e violonista, Othon Salleiro foi também professor. Por indicação de Alberto Valle ${ }^{23}$, o violonista paraense Sebastião Tapajós adquiriu em pouco mais de um mês de curso intensivo a desenvoltura técnica que seria admirada em sua carreira.

Alberto Valle nos relata detalhes sobre este fato:

O Sebastião Tapajós, por exemplo, um oficial do gabinete do governo, me conhecia, e sabia que eu tocava violão, ele conheceu este garoto, que estava com 13 anos, em Santarém e quis que eu ouvisse o

\footnotetext{
${ }^{22}$ Romualdo Miranda (1887 - 1930), violonista, irmão do bandolinista Luperce Miranda (1904 - 1977) com quem fundou o grupo Turunas da Mauricéia, em 1926, no Recife. No ano seguinte fazem sucesso no Rio de Janeiro com as emboladas, cocos e sambas nordestinos, ritmos ainda desconhecidos da capital do país.

${ }^{23}$ Sebastião Tapajós (1944) veio do Pará para o Rio de Janeiro, em 1963, para estudar com Othon Salleiro. No ano seguinte rumou para a Europa, primeiro para Portugal, onde estudou no Conservatório Nacional de Música e posteriormente no Instituto de Cultura Hispânica de Madri.
} 
garoto, para dizer se era bom, ele queria proteger o garoto, eu, então, ouvi o garoto e realmente ele tinha qualidades muito boas de violonista. E ele me perguntou se eu tinha alguém no Rio de Janeiro que pudesse dar um curso para ele, eu disse: tem, e logo lembrei do Salleiro, porque tinha vários violonistas no Rio, mas o Salleiro pelas condições dele, era um médico, um cara inteligente, era médico do exército, tinha profissão, eu conhecia ele já... e fiz uma carta para ele, e ele recebeu o Sebastião, gostou tanto dele, naquela época ele morava em Jacarepaguá, ele gostou tanto do garoto que o acolheu na sua casa, ficou morando com ele, não sei se três ou quatro meses. Quando ele voltou para Belém, deu um recital que ficou todo mundo impressionado, eu não pude assistir, pois nesta época eu estava trabalhando em Manaus. Bom, passado este tempo, este homem do gabinete, conseguiu uma bolsa para ele ir à Espanha, e estudar com Pujol, ficou um ano lá, aí pronto, veio como uma estrela do violão completa, deu condições para ele apresentar suas habilidades e foi embora ${ }^{24}$.

Dilermando Reis era o violonista mais popular de então, como nenhum outro chegara a ser. Sua relação com violonistas como o perfeccionista Othon Salleiro era difícil. Além de certo ciúme pela fama do colega, havia o fato de Dilermando Reis utilizar cordas de aço, o que fazia com que o círculo dos violonistas o olhasse com desconfiança. Compositor de melodias de fácil assimilação, aliadas a soluções harmônicas tradicionais e palatáveis características que fizeram seu sucesso sem precedentes.

${ }^{24}$ Entrevista concedida no Rio de Janeiro, jul. 2006. 
Inserimos aqui um comentário do violonista Fabio Zanon sobre a obra de Othon Salleiro:

É música que carece daquela memorabilidade imediata de seu exato contemporâneo Dilermando Reis, mas que gratifica o ouvinte como escuta prolongada, como é que um compositor sumamente interessante como Othon Salleiro pode permanecer no anonimato? Infelizmente, ele foi o principal culpado, sendo médico, ele comportouse como um amador e nunca se preocupou em escrever e divulgar sua música ${ }^{25}$.

Nicanor Teixeira que, conforme já vimos, foi aluno de Dilermando Reis, esclarece a relação entre os dois violonistas:

Não tinham contato, estes medalhões do passado, hoje é diferente, por causa das faculdades, mas naquela época eles não se misturavam. Ele falou uma vez para mim que foi ver o Dilermando, estavam falando, do garoto paulista, ele foi ver, disse que era muito bom. Naquela época, era época de grandes disputas, tinha muito isto, saber quem tocava bem, mas Salleiro me confessou que Dilermando tocava muito bem, tirava muito som. Ele gostava de Dilermando, ele me contou. Tinha uns caras, rapaz, torciam para o Dilermando morrer para tomar o lugar dele, que coisa, não é? Dilermando era muito seguro, tinha uma unha que era uma pedra, tirava muito som do instrumento.

Ficou um pouco de disputa sim, tanto é que eles não se davam bem, não se relacionavam, pelo contrário, quando Dilermando fez o Xodó da Baiana, Salleiro disse: 'isto é Chiquinha Gonzaga, (cantando) Cortajaca'. E era mesmo!

${ }^{25}$ ZANON. Fabio. In: Violão com Fabio Zanon: Violão Brasileiro. Nossos pioneiros, criadores e intérpretes. Benedito Chaves, Othon Salleiro e J osé Augusto de Freitas. Programa transmitido pela Rádio Cultura, n.49, nov.2006. 
Ele (Salleiro) trabalhava muito as peças, esta era a diferença entre ele e o Dilermando. Dilermando era um melodista muito bom, Uma Valsa e Dois Amores, Se Ela Perguntar, tem muita coisa boa, Magoado, mas as harmonias, terminações, eram sempre parecidas. Salleiro não, Salleiro trabalhava, tinha uma sensibilidade maior, uma harmonia, era mais refiné, criava mais, não era fácil tocar ${ }^{26}$.

Nélio Rodrigues complementa:

Era uma briga constante, porque o Dilermando era artista, talvez mais que o Salleiro, mas não tinha a capacidade de compor e de tocar que tinha o Salleiro 27.

Regina Salleiro, a filha do compositor, ao lembrar-se de Dilermando Reis, conta:

Eles tinham uma briguinha, acho que fizeram um duelo de violão, tocaram para alguém famoso, e parece que falaram: ‘o Othon tocou com muita técnica e Dilermando com o coração, está empatado'. Não conviveram, se encontravam, mas não eram amigos. Dilermando era muito popular, acho que vem um ciúmes mesmo, o Othon era médico, o Dilermando vivia daquilo. Agora, todo dia ele pegava o violão, às vezes era 8 da noite ele estava lá ${ }^{28}$.

Sobre o "duelo", Genésio Nogueira, em sua já citada biografia sobre Dilermando Reis, conta:

\footnotetext{
${ }^{26}$ Entrevista concedida por Nicanor Teixeira, Rio de Janeiro, jul. 2006.

27 Depoimento colhido no Rio de Janeiro, em dez. 2005.

${ }^{28}$ Depoimento colhido em Jacarepaguá, Rio de Janeiro, jul. 2006.
} 
Os amigos de Othon e Dilermando inventaram um confronto entre os dois, onde ambos tocariam algumas peças, sendo julgados por um júri compostos por amigos. Tal confronto deu-se na Taberna da Glória, e sorteado o primeiro a tocar, Dilermando só aceitava tocar se Othon tocasse primeiro. Salleiro não se fez de rogado, e executou o Noturno $\mathrm{n}^{\circ} 2$ opus IX, de Chopin, com transcrição de Tarrega. (...) Dilermando começou a sua parte executando a valsa Saudade de Rio Grande, de Levino da Conceição. (...) Diante de tanto virtuosismo, o Presidente do Júri fez seu julgamento, anunciando o resultado do confronto: 'Como todos vimos e acabamos de ouvir, Othon tocou com o cérebro, e o popular Dilermando com o coração. Por isso não houve vencedor' ${ }^{29}$.

O confronto nos foi narrado em entrevista com Múcio Carias, violonista e amigo de Othon Salleiro, com a mesma riqueza de detalhes e igual veredicto.

São estas poucas as informações mais precisas disponíveis sobre a vida de Salleiro. Conforme notamos, há pouca informação escrita e, por isto, nos valemos da fonte primária das entrevistas com pessoas que conviveram com o compositor. Contamos com a memória destes músicos e amigos, e sendo Othon Salleiro uma figura excêntrica, mais do que informações objetivas temos também um grande anedotário que permanece na memória de todos os contemporâneos, cada um obviamente com suas nuances.

\footnotetext{
${ }^{29}$ In Nogueira, Genésio. Dilermando Reis, Sua Majestade o Violão. Rio de Janeiro: Edição do autor, 2000, p.214.
} 
O fato de usar uma peruca avermelhada para disfarçar a calvície; ter sido expulso de um sarau de Jacob do Bandolim por criticar um violonista de maneira grosseira; ou a folhetinesca história de amor entre o médico psiquiatra e uma noviça ${ }^{30}$, informações como estas talvez ajudem a traçar um perfil do violonista, embora não contribuam diretamente para a compreensão de sua obra.

Por outro lado, é unânime a opinião de Nicanor Teixeira, Jodacil Damasceno, Alberto Valle, Múcio Carias e Nélio Rodrigues de que Salleiro era simplesmente genial quando executava suas próprias peças, mas já não se poderia dizer o mesmo de quando executava peças do repertório clássico do instrumento. Faltava-Ihe talvez o conhecimento mais apurado do texto musical, pois todos os entrevistados afirmam que corria demais, passava por cima de algumas notas, ou tocava notas a mais, como nos revelou Hermínio Bello de Carvalho, em curiosa observação:

Impressionava o repertório do Salleiro: transcrições de obras velocíssimas como o Moto Perpétuo de Paganini, e as composições dele. Tinha uma técnica fenomenal, o que atrapalhava um pouco a concepção de algumas músicas, cujo andamento acelerava de forma quase aflitiva. Um amigo nosso dizia que, com as notas que sobravam da Catedral de Barrios, ele poderia erigir um segundo templo. ${ }^{31}$

30 Maria Salleiro, que foi sua companheira até o final da vida, em 1999, e mãe de sua única filha Regina Salleiro.

${ }^{31}$ Comunicação via correio eletrônico, nov.2006. 
Almejando a posição de solista de violão clássico, conhecendo as obras do repertório tradicional do violão de concerto, dominando os rudimentos da técnica e idiomática do instrumento e tendo convivido no efervescente cenário do violão carioca por onde passaram J osefina Robledo, Agustin Barrios, Isaias Sávio, Narciso Yepes e Andrés Segovia, Salleiro se diferenciava nos círculos da música popular.

Tendo convivendo com a nata da música popular brasileira, conforme vimos acima, Salleiro reuniu materiais temáticos e rítmicos tanto urbanos quanto regionais. Este ambiente musical, aliado às técnicas e texturas do violão de concerto constitui a linguagem instrumental única de Othon Salleiro dentro do universo do violão popular brasileiro.

Assim como a posição de músico amador permitiu a Salleiro dedicar sua produção exclusivamente para violão solo, foi também esta condição que fez com que sua obra passasse despercebida no cenário da produção para o instrumento, uma vez que, conforme vimos, não se preocupava em escrever, gravar ou editar suas músicas, mas apenas em compor e executá-las.

Othon Salleiro faleceu em 1999, em sua casa em Jacarepaguá, no Rio de Janeiro. 


\subsection{Composições}

A obra de Othon Salleiro sobreviveu graças à insistência de alguns amigos violonistas em preservar suas músicas. Mais do que falta de conhecimento musical para escrever, Jodacil Damasceno nos explica qual era o principal motivo para o não registro da própria obra:

Certa vez, eu perguntei a ele: 'professor, porque o senhor não escreve suas músicas que são tão lindas?' Ele virou: 'Para quê? Para assassinarem minhas músicas?' O fato é que quando o Nicanor foi escrever as peças dele, ele passava de mão para mão. Mas acredito que ele soubesse escrever, porque a harmonia dele é fantástica, ele sabia muito bem harmonia, estudou na Escola de Música, com uma professora que eu não lembro agora, mas era muito famosa ${ }^{32}$.

Entre os violonistas que transcreveram a obra de Othon

Salleiro, destacamos Nicanor Teixeira. No início dos anos 70 transcreveu parte da obra do violonista e compositor ${ }^{33}$, e foi o primeiro violonista a dedicar-se a escrever e executar as obras de Othon Salleiro sistematicamente.

Último remanescente da escola do violão brasileiro na linhagem de Dilermando Reis, o compositor e violonista Nicanor

\footnotetext{
32 Depoimento colhido no Rio de Janeiro, jul. 2006.

${ }^{33}$ Infelizmente, a maioria foi extraviada, restaram quatro peças que foram digitalizadas e revisadas para a presente pesquisa, ver partituras em 4.2.3.3, p.149.
} 
Teixeira (1928), nasceu na Barra do Mendes, interior da Bahia, vilarejo situado na bacia do Rio São Francisco.

Em 1977 gravou o disco, de selo independente, O Violão Brasileiro de Nicanor Teixeira, reunindo obras suas e interpretações para clássicos do violão brasileiro, como Sons de Carrilhões, de João Pernambuco, Doutor Sabe Tudo e Magoado, de Dilermando Reis e uma peça de Othon Salleiro, a Berceuse.

O compositor editou músicas no Brasil (Ricordi, Montblanc e Irmãos Vitale), na França (Max Eschig) e Alemanha (Margaux) ${ }^{34}$.

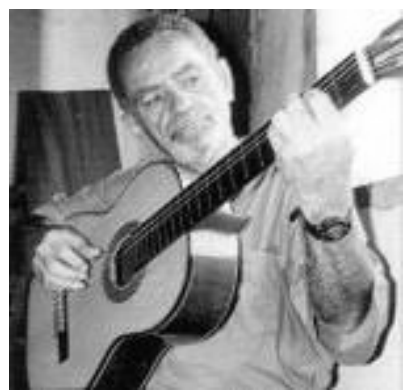

Figura 15. O compositor e violonista baiano Nicanor Teixeira.

Nicanor Teixeira nos conta abaixo o processo das transcrições que realizou nas décadas de 70 e 80 :

Eu tocava muito Salleiro, gostava muito dele, ele explicava os vibratos, às vezes eu mudava um baixo ou outro, ele falava: 'ah, ta bom, pode tocar assim'. Ele não escrevia, ia fazendo, tocando, tinha preguiça de escrever, queria tocar, eu peguei muita coisa dele, escrevi

\footnotetext{
${ }^{34}$ Nicanor Teixeira foi tema de dissertação de mestrado, realizada pela violonista Maria Haro, uruguaia naturalizada brasileira, em 1993, na Escola de Música da Universidade Federal do Rio de Janeiro (UFRJ).
} 
bastante, depois o Nélio fechou, fez aquele livro, gravou. Colei no Salleiro um tempão, durante um ano eu fiquei fazendo transcrições das peças. Depois o Nélio fez as transcrições, é um trabalho muito bonito, foi muito importante, dou meus parabéns para ele. $O$ intuito dele foi resgatar a obra, quando vi me surpreendi ${ }^{35}$.

Regina Salleiro recorda:

E o Nélio também disse que era muito difícil escrever as coisas que ele tocava, que era diferente, também acho que ele escondia um pouco o jogo, para só ele saber como tocava (risos) ${ }^{36}$.

Logo, o processo de compor era feito exclusivamente com o violão em punho, e seguido de algumas anotações, como Maria Salleiro nos relata:

Ele compunha sempre com o violão, e escrevia, anotava tudo, depois me chamava para perguntar, 'como é que fica melhor? Assim, ou de outro jeito?' Eu falava. O Jacob também fazia isto, perguntava a Adília. (Referindo-se a Jacob do Bandolim e sua esposa Adília Bittencourt) ${ }^{37}$.

O único registro que temos do Salleiro como violonista é o incrível LP Violão Brasileiro - Othon Salleiro, Musidisc-HI-FI 2115, da década de 40, além de uma gravação particular, feita ao vivo, em

\footnotetext{
35 Depoimento colhido no Rio de Janeiro, dez. 2005.

${ }^{36}$ Depoimento colhido em Jacarepaguá, em jul. 2006.

37 Idem.
} 
1950, na RGE, em São Paulo, gentilmente cedida pelo colecionador e pesquisador Ronoel Simões.

Sobre o disco, Salleiro mostrou seu perfeccionismo. Forçado pelo pai a fazer a gravação, não se contentou com o resultado. Apesar de ser um dos discos mais impressionantes da história do violão instrumental popular brasileiro, Salleiro alimentou o desejo de retirar o disco de circulação. Ao encontrar o violonista J odacil Damasceno, certa vez, em um ponto de ônibus, foi perguntando se ele possuía o disco. Jodacil respondeu que sim e Salleiro imediatamente: "Por quanto você vende? Eu compro!" 38 .

Nicanor também se recorda da história: “E tem esta estória, que ele queria comprar os discos, saía procurando todo mundo para saber quem tinha, era um perfeccionista".

Sobre o disco, Regina Salleiro relembra:

Meu avô obrigou ele a fazer. Ele disse que o violão que ele tocou, que era muito bom, um espanhol, mas ele achava muito seco e grave, que ele queria tocar num violão mais doce. Por isto, ele não gostou, quis recolher. Meu pai sempre teve uma briguinha com meu avô, eles brigaram do início ao fim do disco. Meu avô fez um conhecimento com gravadora. Uma vez ele gravou na RGE ${ }^{39}$.

\footnotetext{
${ }^{38}$ História relatada pelo próprio J odacil Damasceno, em entrevista, jul. 2006.

39 Gravações realizadas na RGE, em São Paulo, ao vivo, em 14 de abril 1950. Estas gravações não foram comercializadas. Estas gravações foram gentilmente cedidas para a presente pesquisa por Ronoel Simões.
} 
Nélio conta o que Salleiro dizia sobre o referido disco, cerca de 40 anos depois da gravação:

Outra história, é que ele quando resolveu tocar violão, o pai obrigou ele a gravar o disco, às pressas, deve ser verdade, se não for, é a história que ele contava.

Ele me disse para não se basear neste disco que não era bom, me deu o disco, depois tomou de volta, ele não queria que eu me baseasse nele. Acho que ele não queria que se copiasse o que ele fazia naquela época, queria que ficasse o que ele fazia no tempo atual e não no disco daquela época. Não interessa se para mim, ou para você se o disco é melhor, naquela época eu conduzi o trabalho dele como ele queria, ele era o dono do negócio. Hoje eu acharia legal alguém fazer um trabalho pelo disco ${ }^{40}$.

Foi-nos possível encontrar 33 peças do compositor. Em 1964, a revista Violão e Mestres traz a notícia de um recital de Salleiro, na cidade de Poços de Caldas, por ocasião do encerramento do Congresso Pan-americano de Medicina, e aparecem no programa duas obras que não foram localizadas:

Sob os auspícios do Ministério da Saúde, no Palace Hotel, o concerto apresentou esmerado programa no qual figuraram peças de Malats, de

\footnotetext{
40 Depoimento colhido em Maricá, Rio de Janeiro, dez. 2005.
} 
Albeniz e uma Sonata e Fantasia Andina, (grifo nosso) de autoria de Othon Salleiro, esta última dedicada à menina equatoriana Ana Maria, salva pela perícia médica dos cirurgiões do H.S.E ${ }^{41}$.

Nélio Rodrigues, último violonista a ter contato com Othon Salleiro, revisou, editou e gravou, em edição de autor, dezoito peças de compositor. Em sua edição, Rodrigues optou por agrupar as músicas em pequenas suítes temáticas, em um trabalho chamado HOMMAGE, lançado em Paris, em 1999, com o subtítulo: Recueil des Ouvres Pour Guitarre du Compositeur Brésilien. Nélio Rodrigues justifica: “agrupadas sob o nome de suítes em função da elaboração de programas e da performance em público". Ficaram assim agrupadas as dezoito peças recolhidas pelo violonista:

\section{Suíte Emouvante}

- Excelsa

- Conversando com o infinito

- Súplicas de Amor

- Confidências

- Coração de Boêmio

\section{Suite Romantique}

- Luar dos Trópicos

- Ansiedade

${ }^{41}$ Revista Violão e Mestres. São Paulo: Edição Giannini, ago. 1964, p.54. 
- Prece

- Harmonia e Picardia

- Ternura

\section{Suíte Enfantine}

- Berceuse

- Caixinha de música

- Dança Infantil

\section{Suíte Populaire}

- Prelúdio Carioca

- Cavaquinho em Serenata

- Nem a comadre escapa

- Sonho de Cavaquinho

- Batuque

Othon Salleiro, conforme vimos, não tinha o hábito de escrever suas obras, logo a margem de improvisação e de diferentes versões para cada música cresce consideravelmente. Devemos levar em conta o fato de que cada vez que se dispunha a tocar para alguém escrever, tocava de maneira diversa. Nicanor Teixeira lembra, com bom humor:

(...) dava raiva de ver ele tocando, era aquele cara que sempre mudava uma coisa ou outra, e 
dava uma risada: 'olha, como ficou bonito agora! 42 ,

Notamos que cada violonista que transcreveu suas obras deve colocou também uma pitada personalizada. Nicanor Teixeira, conscientemente assume: "Às vezes eu mudava um baixo ou outro", ele falava: "ah, tá bom, pode tocar assim" 43. 


\subsubsection{Catálogo das Obras}

\section{Desconhecemos as datas de composição das obras de Othon}

Salleiro, que não tinha hábito de escrever suas obras. Em seus dois

rascunhos que chegaram até nós, também não consta nenhuma

data.

Segue abaixo, uma primeira catalogação da obra de Salleiro, com o material utilizado e recuperado nesta pesquisa.

\begin{tabular}{|c|c|c|c|}
\hline Título & Edição - Ano & Gravação - ano & Obs. \\
\hline $\begin{array}{l}\text { Allegro } \\
\text { Caprichoso }\end{array}$ & $\begin{array}{l}\text { Partitura Digitalizada - } 2008 \\
\text { Flavia Prando }\end{array}$ & RGE - 1950 Othon Salleiro & Extraída da gravação \\
\hline Ansiedade & $\begin{array}{l}\text { Edições Musicais Aguiar - } 1999 \\
\text { Nélio Rodrigues }\end{array}$ & $\begin{array}{l}\text { Edições Musicais Aguiar - } 1999 \\
\text { N.R. }\end{array}$ & $\begin{array}{l}\text { Álbum de partituras e cd } \\
\text { - Paris/Rio de Janeiro }\end{array}$ \\
\hline \multirow{2}{*}{ Batuque } & $\begin{array}{l}\text { Partitura Digitalizada - } 2008 \\
\text { Flavia Prando }\end{array}$ & $\begin{array}{l}\text { Brasil Music HI-FI, } 2115 \text { - } \\
\text { Othon Salleiro - década de } 40\end{array}$ & Extraída da gravação \\
\hline & $\begin{array}{l}\text { Edições Musicais Aguiar - } 1999 \\
\text { Nélio Rodrigues }\end{array}$ & $\begin{array}{l}\text { Edições Musicais Aguiar - } 1999 \\
\text { N.R. }\end{array}$ & $\begin{array}{l}\text { Álbum de partituras e cd } \\
\text { - Paris/Rio de Janeiro }\end{array}$ \\
\hline \multirow[t]{2}{*}{ Berceuse } & $\begin{array}{l}\text { Partitura Digitalizada - } 2008 \\
\text { Flavia Prando }\end{array}$ & \begin{tabular}{|l|} 
LP O violão brasileiro de \\
Nicanor Teixeira - 1977 \\
Nicanor Teixeira \\
\end{tabular} & Extraída da Gravação \\
\hline & $\begin{array}{l}\text { Edições Musicais Aguiar - } 1999 \\
\text { Nélio Rodrigues }\end{array}$ & $\begin{array}{l}\text { Edições Musicais Aguiar - } 1999 \\
\text { N.R. } \\
\end{array}$ & $\begin{array}{l}\text { Álbum de partituras e cd } \\
\text { - Paris/Rio de Janeiro }\end{array}$ \\
\hline \multirow{2}{*}{$\begin{array}{l}\text { Caixinha de } \\
\text { música }\end{array}$} & $\begin{array}{l}\text { Edições Musicais Aguiar - } 1999 \\
\text { Nélio Rodrigues }\end{array}$ & $\begin{array}{l}\text { Edições Musicais Aguiar - } 1999 \\
\text { N.R. }\end{array}$ & $\begin{array}{l}\text { Álbum de partituras e cd } \\
\text { - Paris/Rio de Janeiro }\end{array}$ \\
\hline & Casa Wehrs 1948 & RGE - 1950 Othon Salleiro & $\begin{array}{l}\text { Othon Salleiro - Rio de } \\
\text { Janeiro }\end{array}$ \\
\hline \multirow{2}{*}{$\begin{array}{l}\text { Cavaquinho em } \\
\text { serenata }\end{array}$} & $\begin{array}{l}\text { Manuscrito Nicanor Teixeira - } \\
1980\end{array}$ & & $\begin{array}{l}\text { Digitalizada - } 2008 \text { Flavia } \\
\text { Prando }\end{array}$ \\
\hline & $\begin{array}{l}\text { Edições Musicais Aguiar - } 1999 \\
\text { Nélio Rodrigues } \\
\end{array}$ & $\begin{array}{l}\text { Edições Musicais Aguiar - } 1999 \\
\text { N.R. }\end{array}$ & $\begin{array}{l}\text { Álbum de partituras e cd } \\
\text { - Paris/Rio de Janeiro }\end{array}$ \\
\hline \multirow[b]{2}{*}{ Chimarrita } & & RGE - 1950 Othon Salleiro & \\
\hline & $\begin{array}{l}\text { Partitura Digitalizada - } 2008 \\
\text { Flavia Prando }\end{array}$ & $\begin{array}{l}\text { Brasil Music HI-FI, } 2115 \text { - } \\
\text { Othon Salleiro - década de } 40\end{array}$ & Extraída da gravação \\
\hline \multirow{2}{*}{ Confidências } & $\begin{array}{l}\text { Partitura Digitalizada - } 2008 \\
\text { Flavia Prando }\end{array}$ & $\begin{array}{l}\text { Brasil Music HI-FI, } 2115 \text { - } \\
\text { Othon Salleiro - década de } 40\end{array}$ & Extraída da gravação \\
\hline & $\begin{array}{l}\text { Edições Musicais Aguiar - } 1999 \\
\text { Nélio Rodrigues }\end{array}$ & $\begin{array}{l}\text { Edições Musicais Aguiar - } 1999 \\
\text { N.R. }\end{array}$ & $\begin{array}{l}\text { Álbum de partituras e cd } \\
\text { - Paris/Rio de Janeiro }\end{array}$ \\
\hline \multirow{2}{*}{$\begin{array}{l}\text { Coração } \\
\text { Boêmio }\end{array}$} & Casa Wehrs 1948 & & $\begin{array}{l}\text { Othon Salleiro - Rio de } \\
\text { Janeiro }\end{array}$ \\
\hline & $\begin{array}{l}\text { Edições Musicais Aguiar - } 1999 \\
\text { Nélio Rodrigues } \\
\end{array}$ & $\begin{array}{l}\text { Edições Musicais Aguiar - } 1999 \\
\text { N.R. }\end{array}$ & $\begin{array}{l}\text { Álbum de partituras e cd } \\
\text { - Paris/Rio de Janeiro }\end{array}$ \\
\hline Dança Árabe & $\begin{array}{l}\text { Partitura digitalizada - década de } \\
90 \text { - Nélio Rodrigues }\end{array}$ & RGE - 1950 Othon Salleiro & Acervo Nélio Rodrigues \\
\hline
\end{tabular}




\begin{tabular}{|c|c|c|c|}
\hline \multirow[t]{2}{*}{ Dança infantil } & $\begin{array}{l}\text { Edições Musicais Aguiar - } 1999 \\
\text { Nélio Rodrigues }\end{array}$ & $\begin{array}{l}\text { Edições Musicais Aguiar - } 1999 \\
\text { N.R. }\end{array}$ & $\begin{array}{l}\text { Álbum de partituras e cd } \\
\text { - Paris/Rio de Janeiro }\end{array}$ \\
\hline & Casa Wehrs 1948 & & $\begin{array}{l}\text { Othon Salleiro - Rio de } \\
\text { Janeiro }\end{array}$ \\
\hline \multirow{2}{*}{$\begin{array}{l}\text { Devaneio } \\
\text { (Conversando } \\
\text { com o infinito) }\end{array}$} & $\begin{array}{l}\text { Edições Musicais Aguiar - } 1999 \\
\text { Nélio Rodrigues }\end{array}$ & $\begin{array}{l}\text { Edições Musicais Aguiar - } 1999 \\
\text { N.R. }\end{array}$ & $\begin{array}{l}\text { Álbum de partituras e cd } \\
\text { - Paris/Rio de Janeiro }\end{array}$ \\
\hline & $\begin{array}{l}\text { Partitura Digitalizada - } 2008 \\
\text { Flavia Prando }\end{array}$ & RGE - 1950 Othon Salleiro & Extraída da gravação \\
\hline $\begin{array}{l}\text { Diálogo } \\
\text { Amoroso }\end{array}$ & $\begin{array}{l}\text { Manuscrito Nicanor Teixeira - } \\
1981\end{array}$ & & $\begin{array}{l}\text { Digitalizada - } 2008 \text { Flavia } \\
\text { Prando }\end{array}$ \\
\hline \multirow{2}{*}{ Excelsa } & $\begin{array}{l}\text { Edições Musicais Aguiar - } 1999 \\
\text { Nélio Rodrigues }\end{array}$ & $\begin{array}{l}\text { Edições Musicais Aguiar - } 1999 \\
\text { N.R. }\end{array}$ & $\begin{array}{l}\text { Álbum de partituras e cd } \\
\text { - Paris/Rio de Janeiro }\end{array}$ \\
\hline & $\begin{array}{l}\text { Partitura Digitalizada - } 2008 \\
\text { Flavia Prando }\end{array}$ & $\begin{array}{l}\text { Brasil Music HI-FI, } 2115 \text { - } \\
\text { Othon Salleiro - década de } 40\end{array}$ & Extraída da gravação \\
\hline $\begin{array}{l}\text { Falando-Ihe de } \\
\text { amor }\end{array}$ & $\begin{array}{l}\text { Partitura Digitalizada - } 2008 \\
\text { Flavia Prando }\end{array}$ & RGE - 1950 Othon Salleiro & Extraída da gravação \\
\hline $\begin{array}{l}\text { Sonata e } \\
\text { Fantasia } \\
\text { Andina } \\
\end{array}$ & Extraviadas & & \\
\hline $\begin{array}{l}\text { Festa do } \\
\text { Bonfim }\end{array}$ & $\begin{array}{l}\text { Partitura Digitalizada - } 2008 \\
\text { Flavia Prando }\end{array}$ & $\begin{array}{l}\text { Brasil Music HI-FI, } 2115 \text { - } \\
\text { Othon Salleiro - década de } 40\end{array}$ & Extraída da gravação \\
\hline \multirow{2}{*}{$\begin{array}{l}\text { Harmonia e } \\
\text { Picardia }\end{array}$} & Casa Wehrs 1948 & RGE - 1950 Othon Salleiro & $\begin{array}{l}\text { Othon Salleiro - Rio de } \\
\text { Janeiro }\end{array}$ \\
\hline & $\begin{array}{l}\text { Edições Musicais Aguiar - } 1999 \\
\text { Nélio Rodrigues }\end{array}$ & $\begin{array}{l}\text { Edições Musicais Aguiar - } 1999 \\
\text { N.R. }\end{array}$ & $\begin{array}{l}\text { Álbum de partituras e cd } \\
\text { - Paris/Rio de Janeiro }\end{array}$ \\
\hline \multirow{2}{*}{$\begin{array}{l}\text { Luar dos } \\
\text { Trópicos }\end{array}$} & $\begin{array}{l}\text { Edições Musicais Aguiar - } 1999 \\
\text { Nélio Rodrigues }\end{array}$ & $\begin{array}{l}\text { Edições Musicais Aguiar - } 1999 \\
\text { N.R. }\end{array}$ & $\begin{array}{l}\text { Álbum de partituras e cd } \\
\text { - Paris/Rio de Janeiro }\end{array}$ \\
\hline & $\begin{array}{l}\text { Partitura Digitalizada - } 2008 \\
\text { Flavia Prando }\end{array}$ & $\begin{array}{l}\text { Brasil Music HI-FI, } 2115 \text { - } \\
\text { Othon Salleiro - década de } 40 \\
\end{array}$ & Extraída da gravação \\
\hline $\begin{array}{l}\text { Miudinho } \\
\text { Chegadinho }\end{array}$ & $\begin{array}{l}\text { Partitura digitalizada - década de } \\
90 \text { - Nélio Rodrigues }\end{array}$ & & Acervo Nélio Rodrigues \\
\hline \multirow{2}{*}{$\begin{array}{l}\text { Nem a } \\
\text { comadre } \\
\text { escapa - Côco } \\
\text { Baião }\end{array}$} & $\begin{array}{l}\text { Edições Musicais Aguiar - } 1999 \\
\text { Nélio Rodrigues }\end{array}$ & $\begin{array}{l}\text { Edições Musicais Aguiar - } 1999 \\
\text { N.R. }\end{array}$ & $\begin{array}{l}\text { Álbum de partituras e cd } \\
\text { - Paris/Rio de Janeiro }\end{array}$ \\
\hline & $\begin{array}{l}\text { Partitura Digitalizada - } 2008 \\
\text { Flavia Prando }\end{array}$ & $\begin{array}{l}\text { Brasil Music HI-FI, } 2115 \text { - } \\
\text { Othon Salleiro - década de } 40\end{array}$ & Extraída da gravação \\
\hline \multirow{2}{*}{$\begin{array}{l}\text { Perfume da } \\
\text { saudade }\end{array}$} & $\begin{array}{l}\text { Partitura digitalizada - década de } \\
90 \text { - Nélio Rodrigues }\end{array}$ & & Acervo Nélio Rodrigues \\
\hline & Casa Wehrs 1948 & & $\begin{array}{l}\text { Othon Salleiro - Rio de } \\
\text { Janeiro }\end{array}$ \\
\hline \multirow{2}{*}{ Prece } & $\begin{array}{l}\text { Edições Musicais Aguiar - } 1999 \\
\text { Nélio Rodrigues }\end{array}$ & $\begin{array}{l}\text { Edições Musicais Aguiar - } 1999 \\
\text { N.R. }\end{array}$ & $\begin{array}{l}\text { Álbum de partituras e cd } \\
\text { - Paris/Rio de Janeiro }\end{array}$ \\
\hline & $\begin{array}{l}\text { Manuscrito Nicanor Teixeira - } \\
1980\end{array}$ & & $\begin{array}{l}\text { Digitalizada - } 2008 \text { Flavia } \\
\text { Prando }\end{array}$ \\
\hline \multirow{2}{*}{$\begin{array}{l}\text { Prelúdio } \\
\text { Carioca }\end{array}$} & $\begin{array}{l}\text { Manuscrito Nicanor Teixeira - } \\
1980\end{array}$ & & $\begin{array}{l}\text { Digitalizada - } 2008 \text { Flavia } \\
\text { Prando }\end{array}$ \\
\hline & $\begin{array}{l}\text { Edições Musicais Aguiar - } 1999 \\
\text { Nélio Rodrigues }\end{array}$ & $\begin{array}{l}\text { Edições Musicais Aguiar - } 1999 \\
\text { N.R. }\end{array}$ & $\begin{array}{l}\text { Álbum de partituras e cd } \\
\text { - Paris/Rio de Janeiro }\end{array}$ \\
\hline $\begin{array}{l}\text { Quebra - coco } \\
\text { (batuque) }\end{array}$ & $\begin{array}{l}\text { Partitura Digitalizada - } 2008 \\
\text { Flavia Prando }\end{array}$ & RGE - 1950 Othon Salleiro & Extraída da gravação \\
\hline \multirow{2}{*}{$\begin{array}{l}\text { Reminiscências } \\
\text { Cariocas }\end{array}$} & $\begin{array}{l}\text { Manuscrito Nicolas de Souza } \\
\text { Barros - } 2003\end{array}$ & & $\begin{array}{l}\text { Digitalizada - } 2008 \\
\text { Flavia Prando }\end{array}$ \\
\hline & $\begin{array}{l}\text { Partitura Digitalizada - } 2008 \\
\text { Flavia Prando }\end{array}$ & $\begin{array}{l}\text { Brasil Music HI-FI, } 2115 \text { - } \\
\text { Othon Salleiro - década de } 40\end{array}$ & $\begin{array}{l}\text { Manuscrito Nicolas de } \\
\text { Souza Barros - } 2003\end{array}$ \\
\hline $\begin{array}{l}\text { Repinicado de } \\
\text { viola }\end{array}$ & $\begin{array}{l}\text { Partitura Digitalizada - } 2008 \\
\text { Flavia Prando }\end{array}$ & RGE - 1950 Othon Salleiro & Extraída da gravação \\
\hline $\begin{array}{l}\text { Choro } \\
\text { Seresteiro }\end{array}$ & $\begin{array}{l}\text { Partitura digitalizada - década de } \\
90 \text { - Nélio Rodrigues }\end{array}$ & & $\begin{array}{l}\text { Acervo Nélio Rodrigues - } \\
\text { Parceria com Eduardinho } \\
\text { da Piedade }\end{array}$ \\
\hline
\end{tabular}




\begin{tabular}{|c|c|c|c|}
\hline $\begin{array}{l}\text { Sonhando na } \\
\text { Rede }\end{array}$ & $\begin{array}{l}\text { Partitura digitalizada - década de } \\
90 \text { - Nélio Rodrigues }\end{array}$ & & $\begin{array}{l}\text { Acervo Nélio Rodrigues - } \\
\text { Parceria com J oão } \\
\text { Pernambuco (?) }\end{array}$ \\
\hline \multirow{2}{*}{$\begin{array}{l}\text { Sonho de } \\
\text { Cavaquinho }\end{array}$} & $\begin{array}{l}\text { Edições Musicais Aguiar - } 1999 \\
\text { Nélio Rodrigues }\end{array}$ & $\begin{array}{l}\text { Edições Musicais Aguiar - } 1999 \\
\text { N.R. }\end{array}$ & $\begin{array}{l}\text { Álbum de partituras e cd } \\
\text { - Paris/Rio de Janeiro }\end{array}$ \\
\hline & $\begin{array}{l}\text { Partitura Digitalizada - } 2008 \\
\text { Flavia Prando }\end{array}$ & & $\begin{array}{l}\text { Partitura confeccionada a } \\
\text { partir do rascunho do } \\
\text { compositor }\end{array}$ \\
\hline \multirow{2}{*}{$\begin{array}{l}\text { Súplicas de } \\
\text { amor }\end{array}$} & $\begin{array}{l}\text { Edições Musicais Aguiar - } 1999 \\
\text { Nélio Rodrigues }\end{array}$ & $\begin{array}{l}\text { Edições Musicais Aguiar - } 1999 \\
\text { N.R. }\end{array}$ & $\begin{array}{l}\text { Álbum de partituras e cd } \\
\text { - Paris/Rio de Janeiro }\end{array}$ \\
\hline & Casa Wehrs 1948 & & $\begin{array}{l}\text { Othon Salleiro - Rio de } \\
\text { Janeiro }\end{array}$ \\
\hline \multirow{2}{*}{ Ternura } & $\begin{array}{l}\text { Edições Musicais Aguiar - } 1999 \\
\text { Nélio Rodrigues }\end{array}$ & $\begin{array}{l}\text { Edições Musicais Aguiar - } 1999 \\
\text { N.R. }\end{array}$ & $\begin{array}{l}\text { Álbum de partituras e cd } \\
\text { - Paris/Rio de Janeiro }\end{array}$ \\
\hline & $\begin{array}{l}\text { Partitura Digitalizada - } 2008 \\
\text { Flavia Prando }\end{array}$ & $\begin{array}{l}\text { Brasil Music HI-FI, } 2115 \text { - } \\
\text { Othon Salleiro - década de } 40\end{array}$ & Extraída da gravação \\
\hline $\begin{array}{l}\text { Toada } \\
\text { Sertaneja }\end{array}$ & $\begin{array}{l}\text { Partitura Digitalizada - } 2008 \\
\text { Flavia Prando }\end{array}$ & RGE - 1950 Othon Salleiro & Extraída da gravação \\
\hline \multirow{2}{*}{$\begin{array}{l}\text { Viola da } \\
\text { Saudade }\end{array}$} & $\begin{array}{l}\text { Partitura Digitalizada - } 2008 \\
\text { Flavia Prando }\end{array}$ & $\begin{array}{l}\text { Brasil Music HI - FI, } 2115 \text { - } \\
\text { Othon Salleiro - década de } 40\end{array}$ & Extraída da gravação \\
\hline & $\begin{array}{l}\text { Partitura digitalizada - década de } \\
90 \text { - Nélio Rodrigues }\end{array}$ & & Acervo Nélio Rodrigues \\
\hline
\end{tabular}




\subsubsection{Estilos composicionais na obra de Othon Salleiro}

Como vimos, Barrios foi o compositor que mais influenciou Othon Salleiro. Um dos aspectos que nos chamou atenção é a exploração dos perfis estéticos diferenciados, que também são visíveis na produção do compositor carioca. Sobre este ponto de vista, arriscamos uma classificação por estilos da obra de Salleiro que segue de perto a de Barrios, de acordo com o que comentamos sobre o autor de Sueño en La Floresta ${ }^{43}$.

Vale lembrar que a classificação por gêneros não é tarefa fácil neste período da literatura musical brasileira, por isto vamos evitar ser taxativos neste sentido. Citamos Mario de Andrade, no Dicionário Musical Brasileiro, que comenta pertinentemente a questão:
(...) Essa confusão proveio principalmente da música, porque todas essas formas, se conformando ao binário de dois-por-quatro que é a obsessão do nosso populário musical, e se prestando às fórmulas rítmicas sincopadas, fizeram com que os cateretês, as emboladas, os sambas pudessem ser dançados conforme a coreografia do maxixe.

Detectamos em Barrios duas grandes vertentes: a da música de salão, de influência tarreguiana, e a das diversas tradições

\footnotetext{
${ }^{43}$ Ver capítullo 2, p. 30.
} 
populares. Já em Salleiro, sob a influência do mestre paraguaio, percebemos os universos da música carioca urbana, da tradição sertaneja, das influências latino-americanas e da tradição herdada de Tarrega e Barrios.

Segue abaixo nossa classificação por grupos temáticos da obra de Othon Salleiro:

\title{
Música Urbana Carioca:
}

\author{
Batuque \\ Batuque - Santos \\ Cavaquinho em Serenata \\ Choro Seresteiro \\ Choro-Boêmio \\ Côco-Baião \\ Dialogo Amoroso \\ Falando-Ihe de Amor \\ Festa do Bonfim \\ Harmonia e Picardia \\ Luar dos Trópicos \\ Perfume da Saudade \\ Quebra-côco \\ Reminiscências Cariocas \\ Sonhando na Rede \\ Sonho de Cavaquinho \\ Súplicas de Amor
}

\section{Tradição Sertaneja:}

Miudinho Chegadinho

Repinicado de Viola

Toada Sertaneja

Viola da Saudade

Peças de caráter da tradição Tarrega-Barrios:
Allegro Caprichoso
Ansiedade
Berceuse
Caixinha de Música
Confidências
Dança Árabe
Dança Infantil
Devaneios 
Excelsa

Prece

Ternura

\section{I nfluência Latino-América:}

Chimarrita

Sonata e Fantasia Andina (extraviadas)

Dentro da música urbana carioca, encontramos os variados gêneros: valsas, batuques, choros e maxixes. Lembramos que se incluem aqui a música urbana já impregnada dos ritmos do norte e nordeste do país.

As músicas da tradição sertaneja revelam o universo das modas de viola caipira. Conforme já vimos, Othon Salleiro compôs músicas que fogem à temática urbana da música carioca.

Encontramos três gravações e uma partitura no acervo de Nélio Rodrigues, onde o compositor afina o violão imitando uma das scordaturas da viola caipira, o cebolão em ré (1aㅡ ré, $2^{\underline{a}}$ si, $3^{\underline{a}}$ sol, $4^{\underline{a}}$ ré, 5a sol, 6a ré).

Nas diversas peças de caráter da tradição Tarrega-Barrios encontramos a influência do período romântico do violão através de Tarrega e Barrios. São obras que utilizam as texturas e técnicas do violão de concerto.

Embora a influência latino-americana seja marcante na obra de Othon Salleiro, do ponto de vista temático restou-nos apenas a Chimarrita como exemplo, uma vez que a Sonata e Fantasia Andina não chegaram até nós. 


\subsubsection{Partituras}

\subsubsection{Editadas pela Casa Wehrs}

Sabemos que Othon Salleiro não tinha por hábito escrever suas músicas. Possivelmente estas obras editadas pela Casa Wehrs foram escritas pelo compositor, segundo nos relataram Jodacil Damasceno e Nicanor Teixeira ${ }^{44}$.

\section{Caixinha de Música}

Peça de caráter, com estrutura simples, tem forma ternária ABA. A parte A está na tonalidade de Lá Maior e a parte $\mathbf{B}$ em Mi Maior. Para a imitação do timbre das caixinhas de música, a melodia da peça é feita totalmente em harmônicos.

Esquema formal:

$$
\begin{aligned}
& \text { A - comp. } 1 \text { ao comp. 18; } \\
& \text { B - comp. } 18 \text { ao comp. } 34 ; \\
& \text { A - comp. } 1 \text { ao comp. } 16 \text { e final comp. } 35 \text {. }
\end{aligned}
$$

\section{Coração de Boêmio}

Choro bastante convencional em forma de um rondó, ABACA. A parte $\mathbf{A}$, em mi menor desenvolve-se através de uma figura rítmica tradicional do choro ( e escalas derivadas de acordes com estrutura harmônica simples.

\footnotetext{
${ }^{44}$ Em entrevistas concedidas no Rio de Janeiro, jul. 2005.
} 
A parte B, também na tonalidade de mi menor, o autor utilizase dos rasgueos e há a indicação "imitando cavaquinho" nestes rasgueos; das escalas derivadas de acordes. Notamos o interessante efeito criado a partir do compasso 28 , com as terças na região aguda e as décimas na voz mais grave.

Na parte $\mathbf{C}$, na tonalidade homônima maior, há o uso das campanellas (c. 56, c.63, 64, 65. Nota-se o interessante jogo rítmico formado a partir do compasso 61 , com o deslocamento do tempo forte através da utilização de acordes nos tempos fracos. Esta seção termina com uma seqüência de acordes com uma típica melodia no baixo ( $)$ ).

Destacamos a reexposição da parte $\mathbf{A}$, que apresenta pequenas variações nos acordes e arpejos (c.45, 46).

Esquema formal:

$$
\begin{aligned}
& \text { A - comp. } 1 \text { ao comp. } 16 ; \\
& \text { Ponte - comp. } 18 ; \\
& \text { B - comp. } 19 \text { ao comp. } 39 ; \\
& \text { A - comp. } 40 \text { ao do comp. } 55 \text {; } \\
& \text { C - comp. } 56 \text { ao c. } 71 ; \\
& \text { A - comp. } 1 \text { ao do comp. } 17 \text {. }
\end{aligned}
$$

\section{Dança I nfantil}

Peça de caráter, com estrutura bastante simples, lembrando Francisco Tarrega. Tem estrutura ternária ABA. A parte A apresenta uma frase de oito compassos, em Mi Maior. A parte B, na tonalidade 
de Si Maior, conta com dezesseis compassos e apresenta seqüências de sextas. Na reexposição da parte $\mathbf{A}$, a melodia aparece oitava abaixo.

Esquema formal:

$$
\begin{aligned}
& \text { A - comp. } 1 \text { ao comp. } 8 \\
& \text { B - comp. } 9 \text { ao comp. } 24 ; \\
& \text { A - comp. } 25 \text { ao do comp. } 32 \text {. }
\end{aligned}
$$

\section{Harmonia e Picardia}

Choro lento, com a sexta corda afinada em ré. Com duas partes, apresenta-se na forma ternária simples, na tonalidade de ré menor.

A parte A apresenta caráter seresteiro, como indica a dedicatória do autor: A velha guarda e a Nova-Guarda dos seresteiro e chorões brasileiros. À maneira tradicional, o tema surge dos acordes arpejados e há o diálogo com uma melodia no baixo que aparece com a indicação de articulação stacatto. Notamos a utilização expressiva das fermatas nas notas agudas (c. 3 e 4).

A parte B, na mesma tonalidade apresenta um tema na região aguda do instrumento. Chamamos a atenção para o compasso 21 onde através do grupo de quatro fusas repetidas quatro vezes com a indicação stringendo, o compositor confere interessante impulso rítmico nesta seção. Seguem-se os acordes e arpejos e o diálogo entre a melodia do baixo também em stacatto. 
Esquema formal:

A - comp. 1 ao comp. 15;

Ponte - comp.17;

B - comp. 18 ao comp.36;

A - comp. 1 até do comp.16.

\section{Perfume da Saudade}

Valsa lenta, inserida na tradição das serenatas, abaixo do título há um poema de Otto Rodrigues, para quem Salleiro dedica esta valsa:

Quando há luar no meu coração, Uma saudade que não me maltrata, Mas que, pouco a pouco me mata, Vem me dar serenata.

Perfume da Saudade tem forma ternária simples ABA, na tonalidade de mi menor. A peça inicia-se com as recorrentes décimas e desenvolve-se através das melodias derivadas dos acordes. Nota-se o uso das tercinas (c.4) e as indicações incomuns: murmurando, sentido, intimo, além do uso dos harmônicos na parte B.

Esquema formal:

A - comp. 1 ao comp. 25;

B - comp. 26 ao comp.57;

A - comp. 1 ao do comp. 25. 


\section{Súplicas de Amor}

Valsa lenta, inserida na tradição das valsas brasileiras, em mi menor. Apresenta forma ternária simples ABA. Na parte $\mathbf{A}$, a melodia é apresenta na região média do instrumento e é acompanhada por acordes. Nota-se o uso dos harmônicos (c.12, 28, $30,31,32,33)$, o uso das sextas e oitavas (c.5, 13) e o abuso das fermatas (c. $3,5,7,17,19)$, além do uso não convencional do termo stressando, possivelmente para indicar stringendo, uma vez que a palavra stressando, derivada de stress, palavra de origem inglesa e não é utilizada no idioma italiano.

Na parte B, ainda em mi menor, nota-se o uso das oitavas e décimas (c.37, 39 e 41) e o uso dos harmônicos naturais e artificiais a partir do compasso 45 .

Esquema formal:

A - comp. 1 ao comp. 32;

Ponte - comp.34 e 35;

B - comp. 36 ao comp.52;

A - comp. 1 ao do comp. 33 . 


\section{CAIXINHA DE MUSICA \\ VIOLÃO}

Othon SALLEIRO

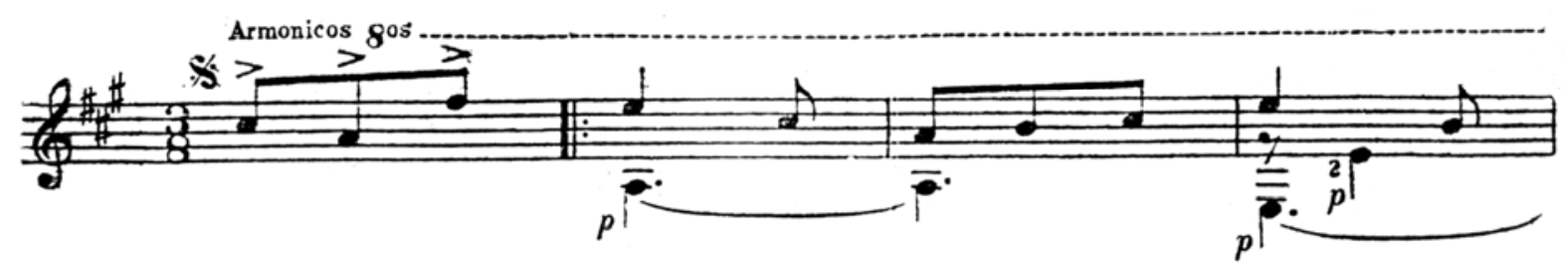

ate ofim.
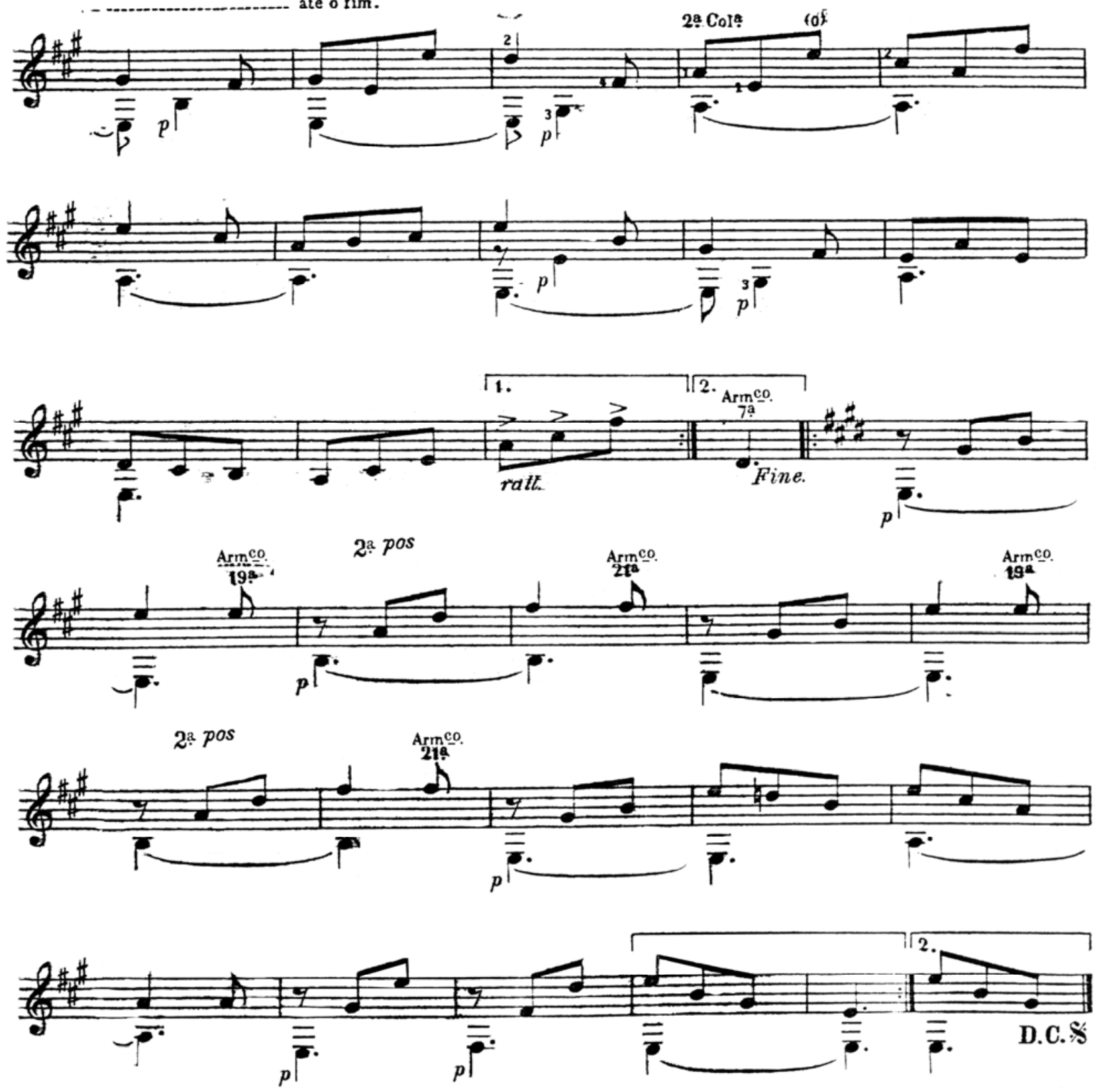

Propriedade reservada 


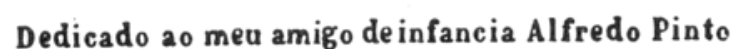 \\ CORAÇẤO DE BOÊMIO \\ CHÔRO}

Othon Salleiro
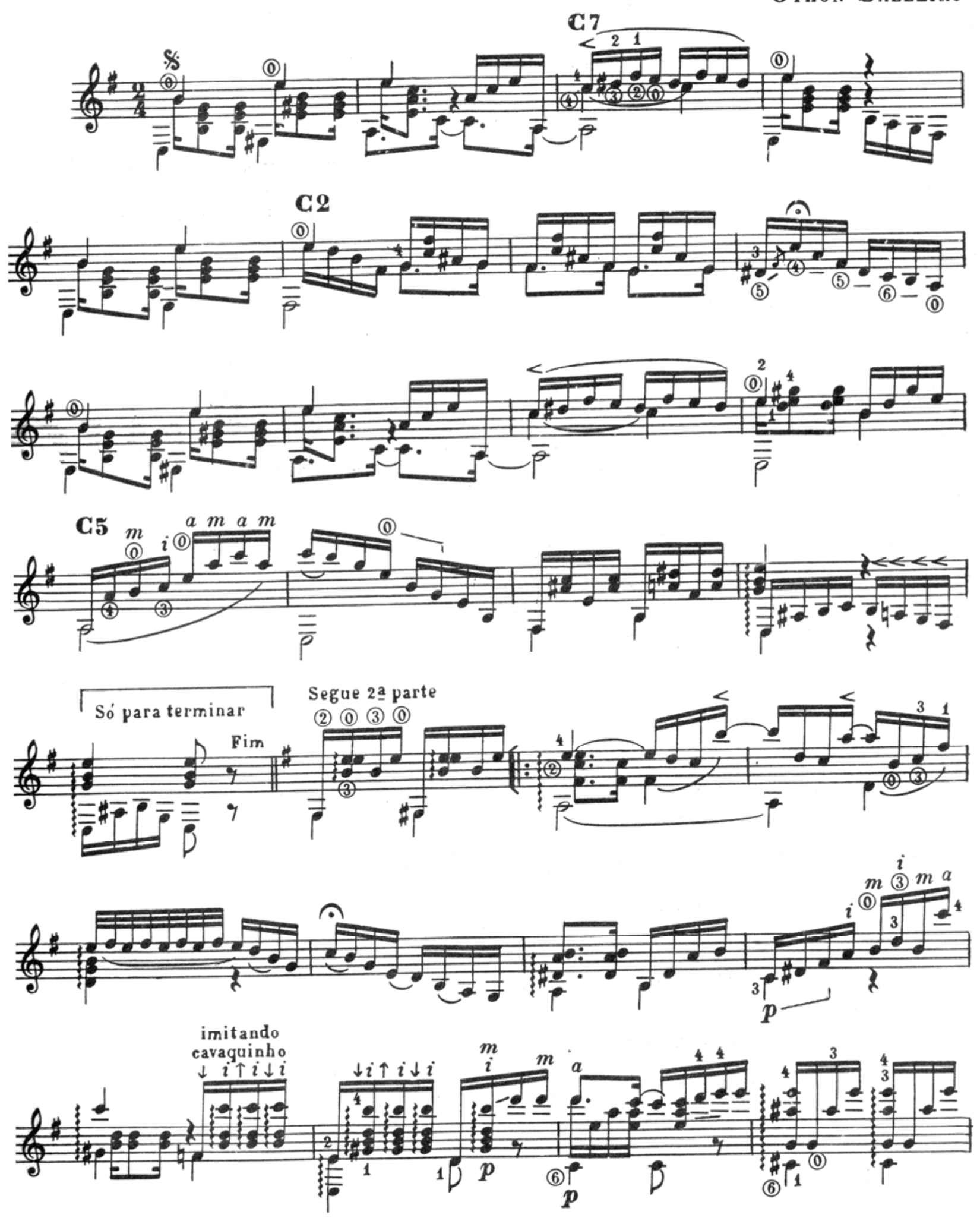


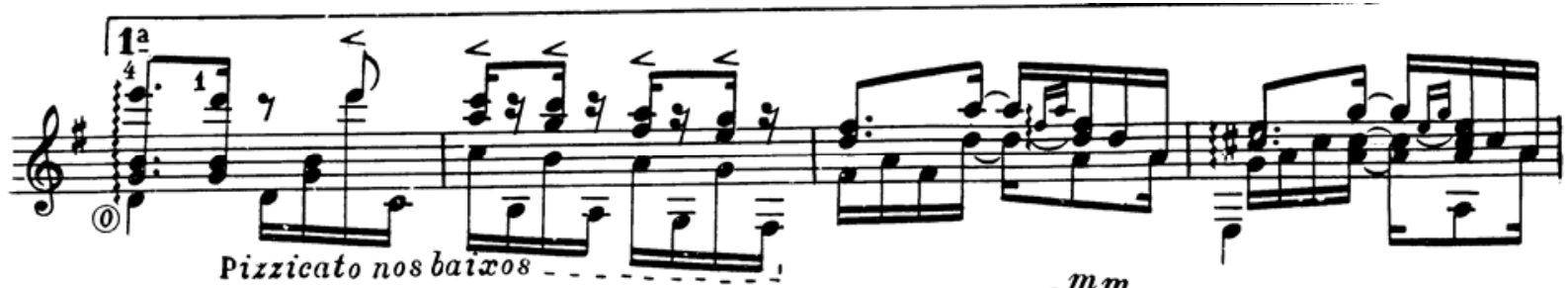

(2)

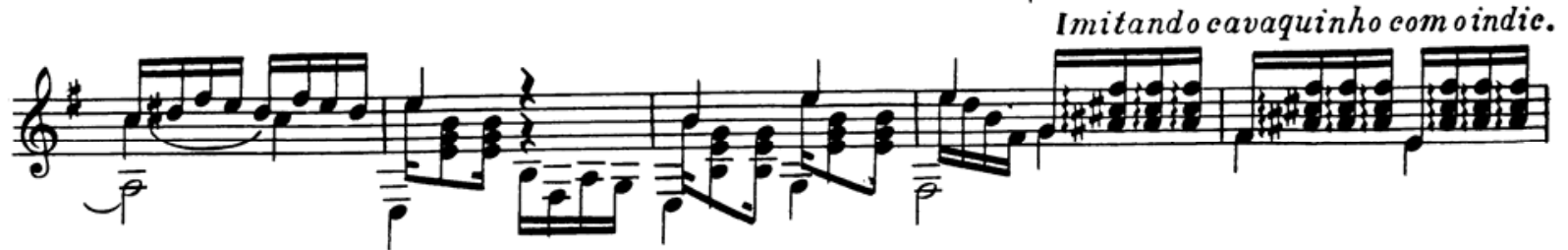

(1)
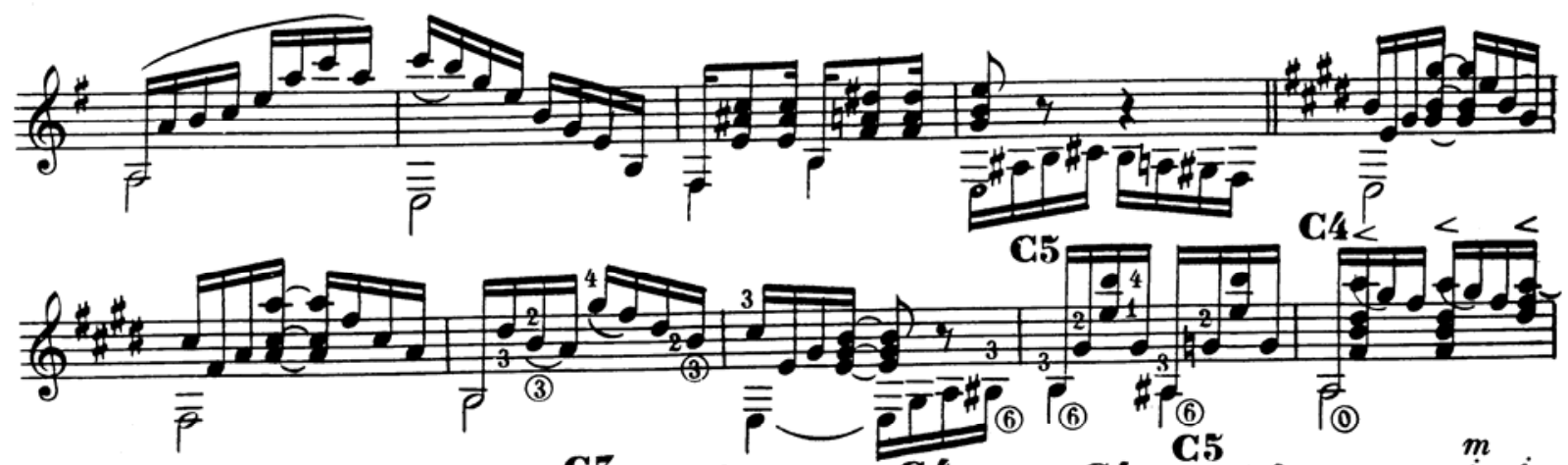

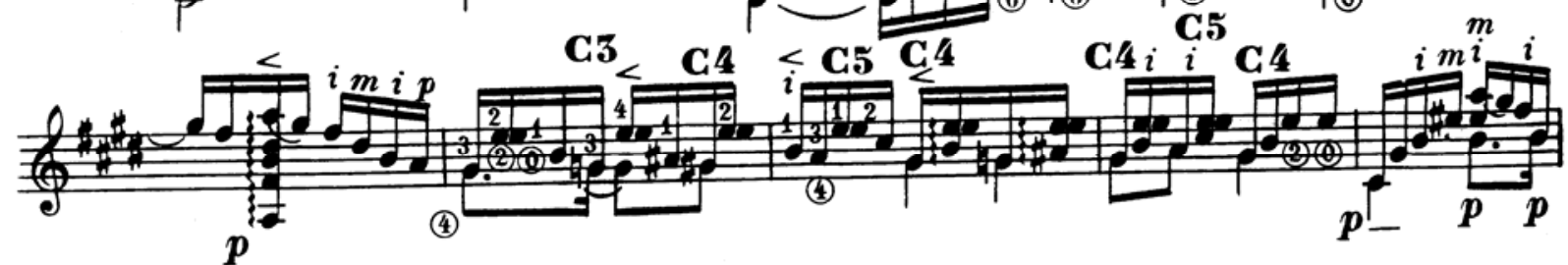

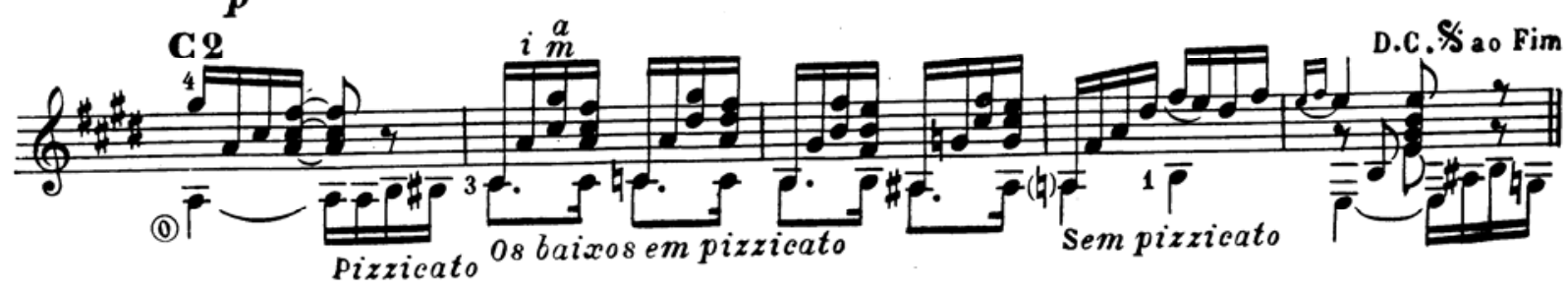

EM 50 


\section{DANSA INFANTIL VIOLÃo}

OTHON SALLeIRo
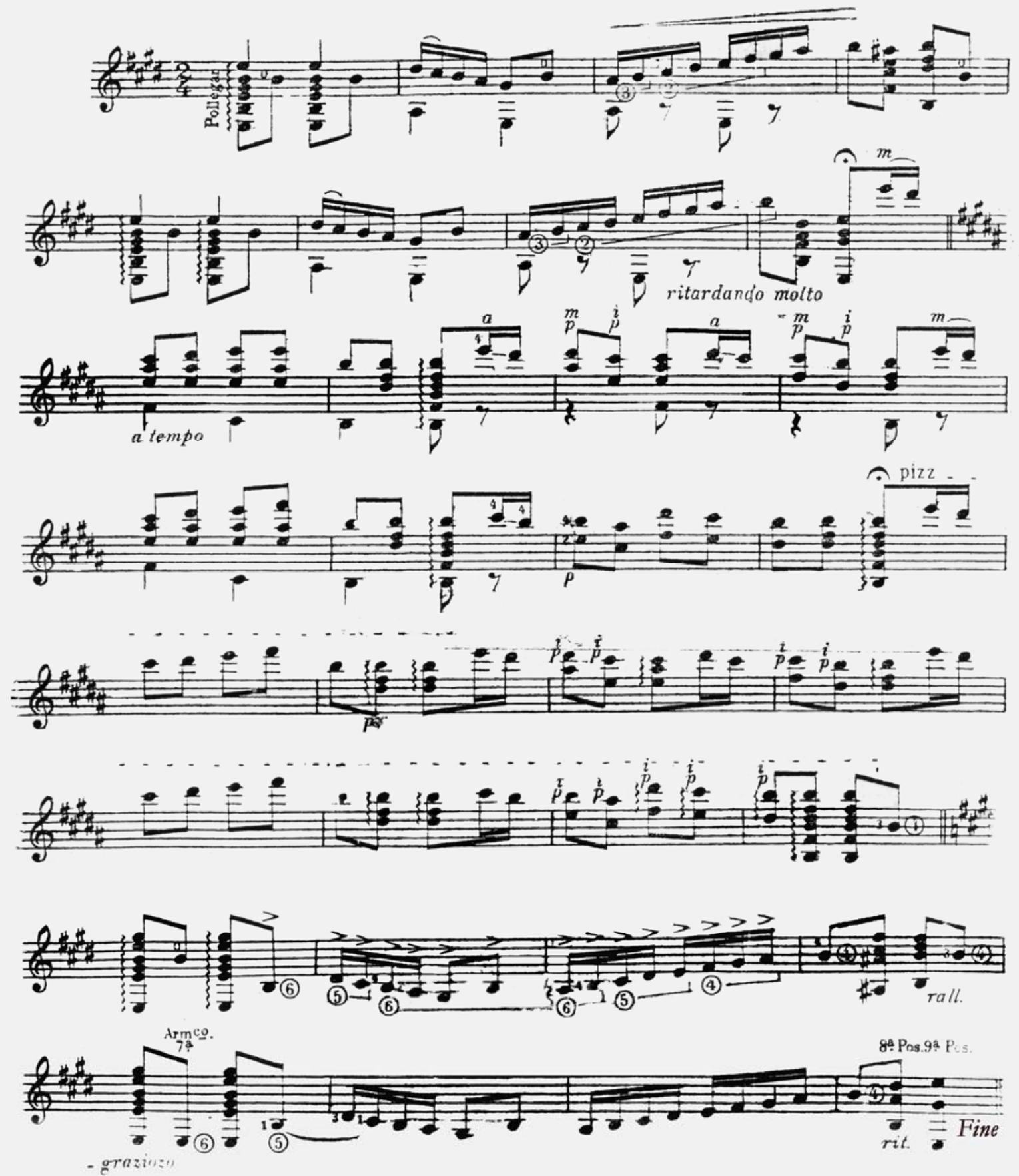


\section{Á velha guarda e a Nova-Guarda dos seresteirosechoröes brasileiros}

\section{HARMONIA E PICARDIA}

Othon Saleiro
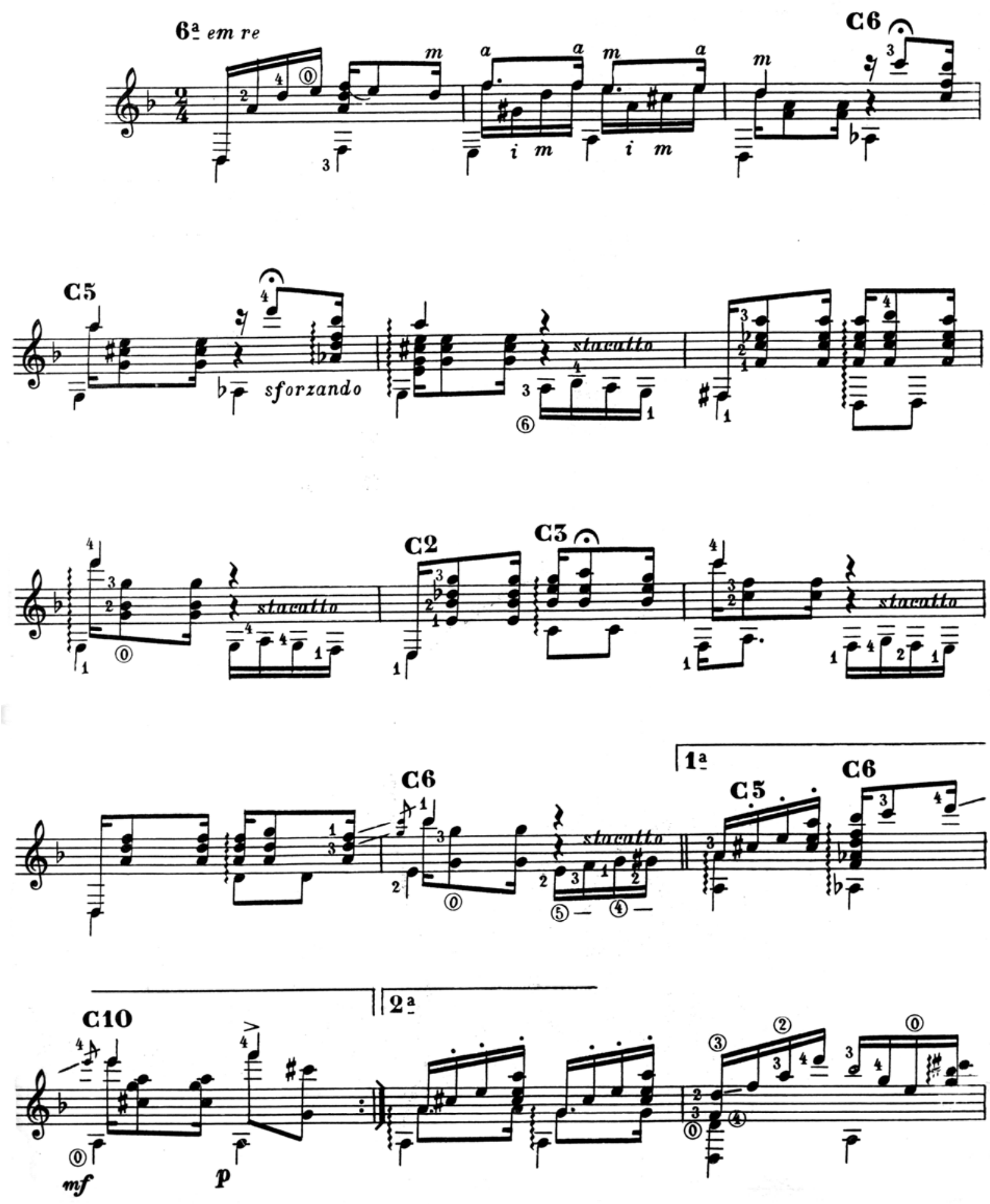

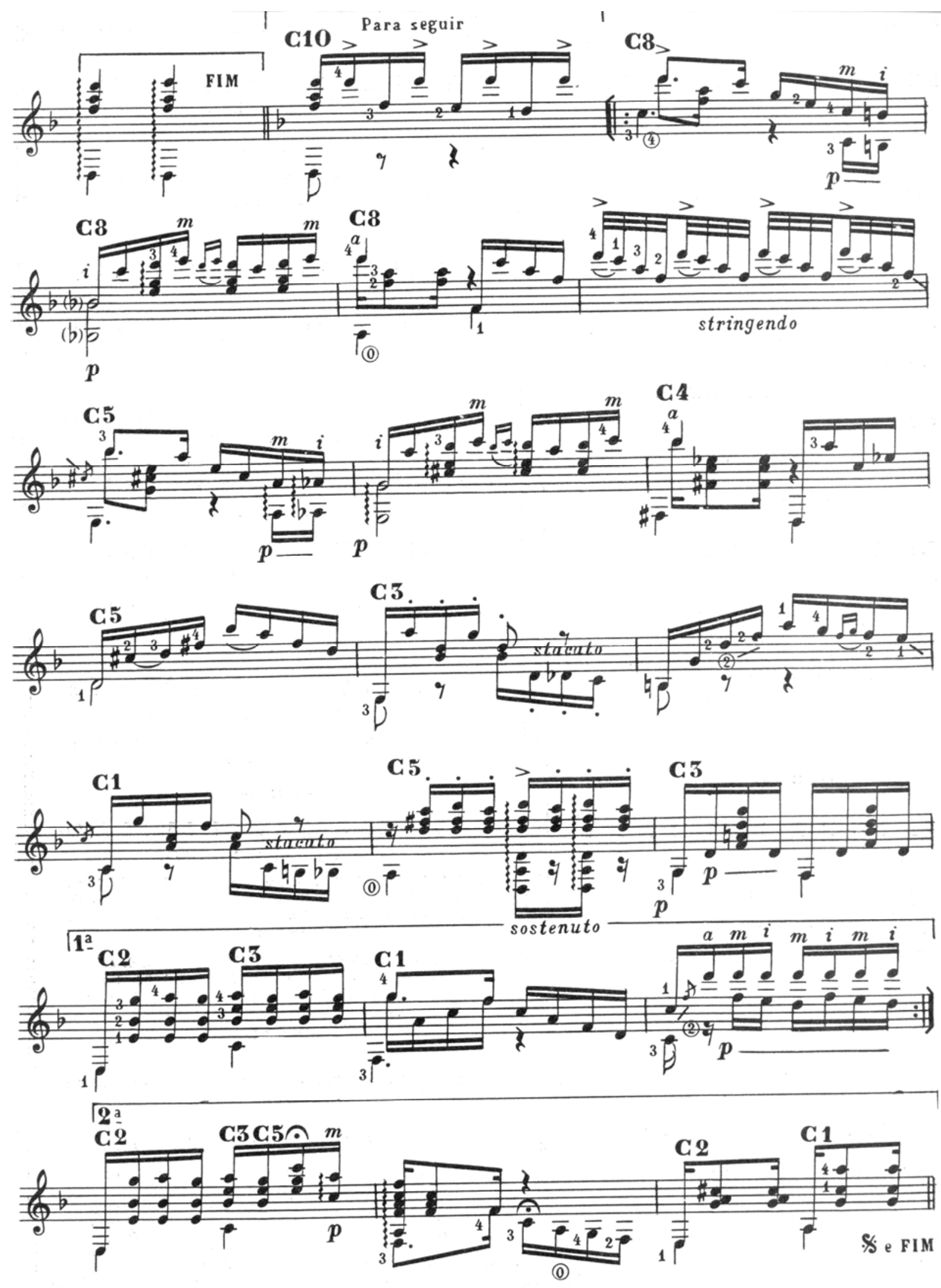


\section{PERFUME DA SAUDADE \\ VALSA}

Ao meu amigo 0tto Rodrigues jue escreveu:

Quando há luar no meu coração,

Uma saudade que não me maltrata,

Mas que, pouco a pouco me mata,

Vem me dar serenata.

Othon Saleiro
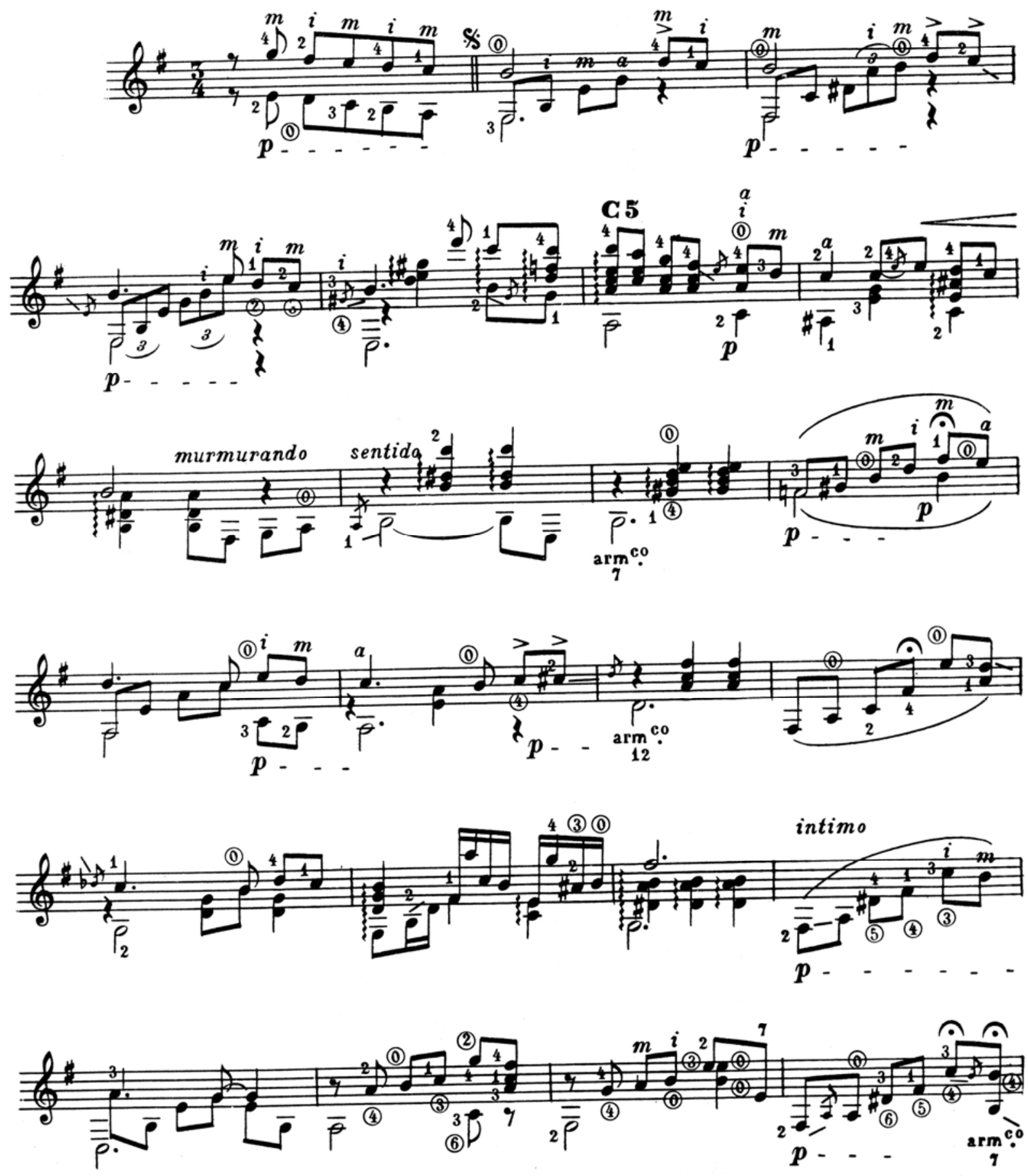

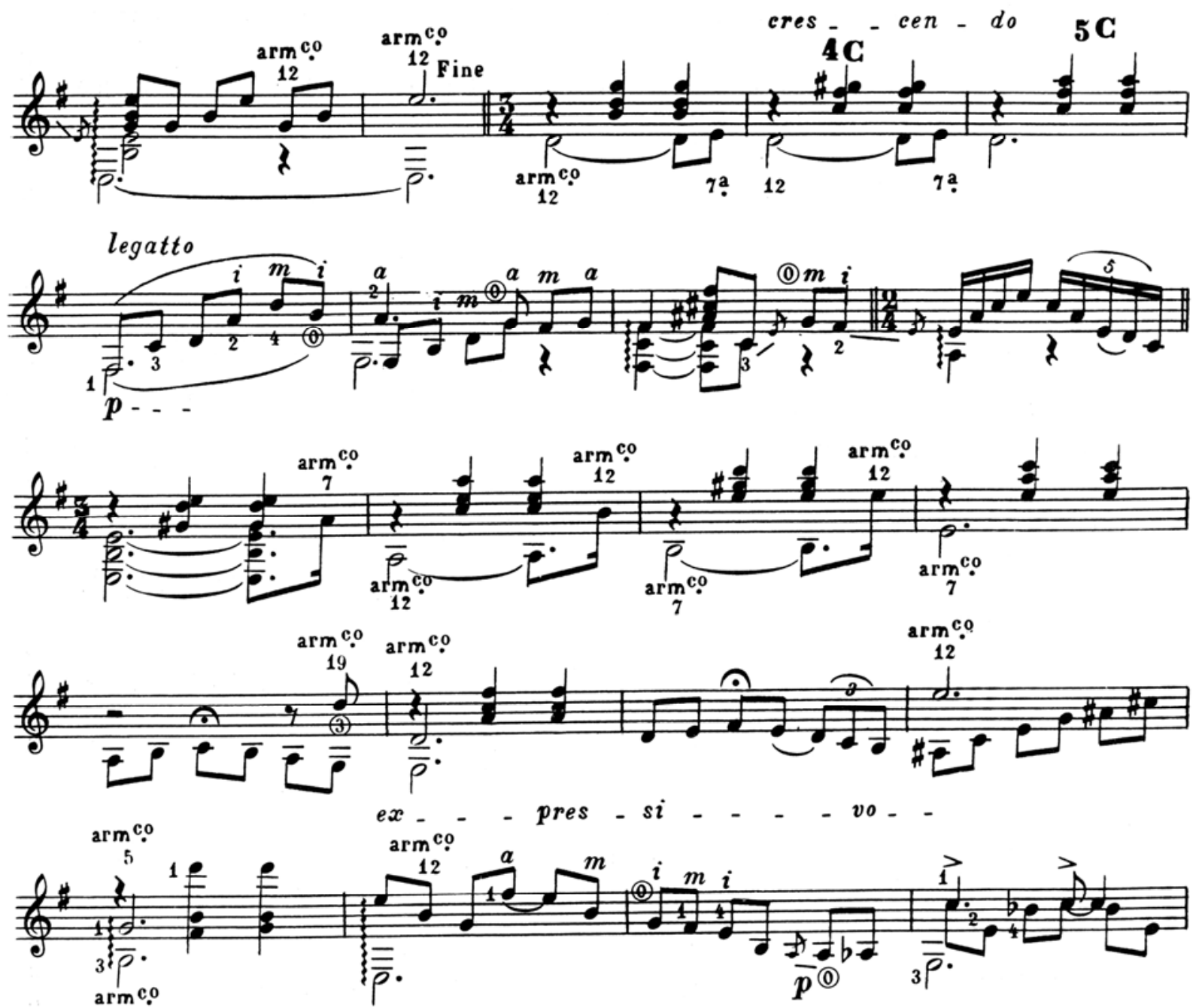

$8 \mathrm{C}$
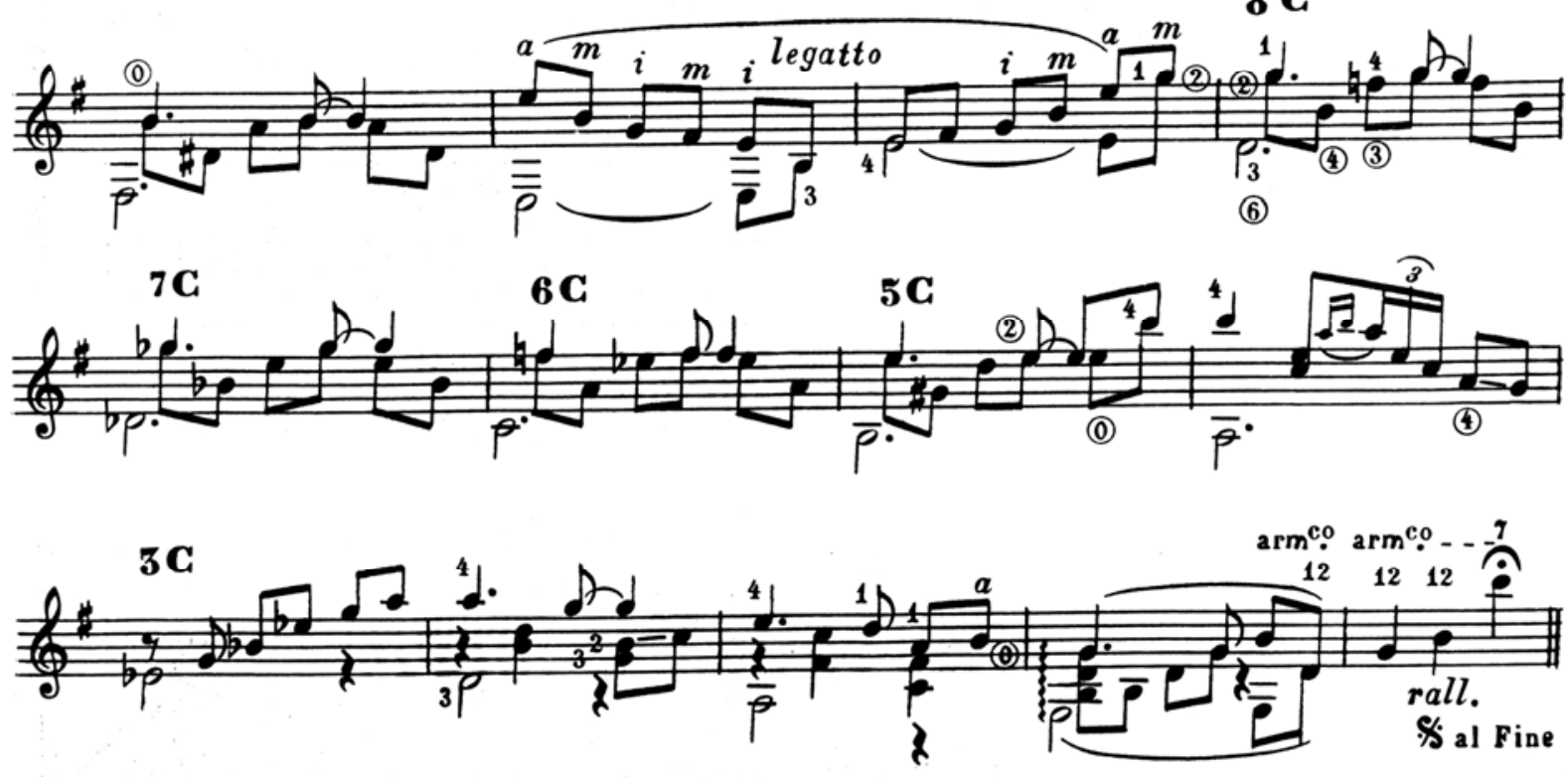


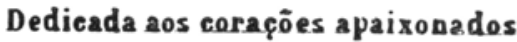 \\ SÚPLIGAS DE AMOR \\ VALSA}

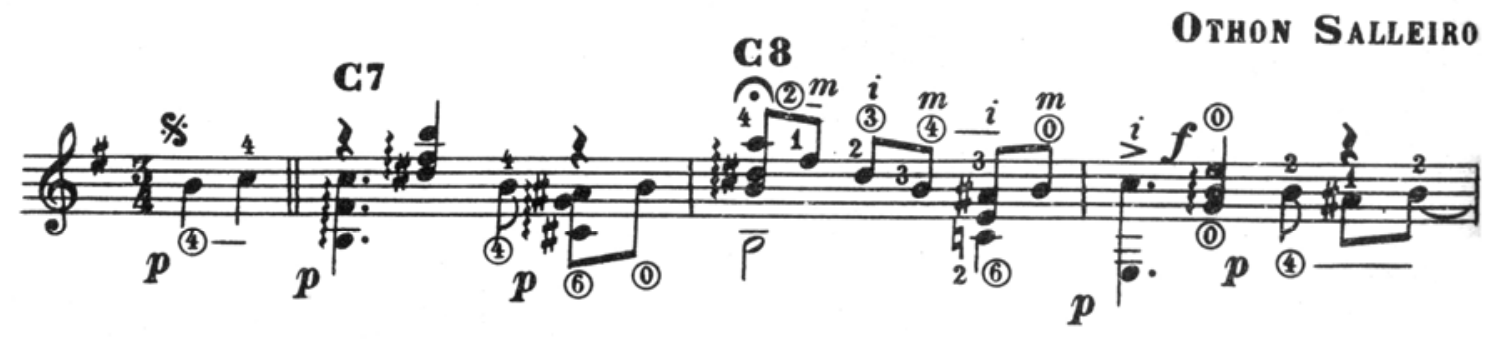

C9
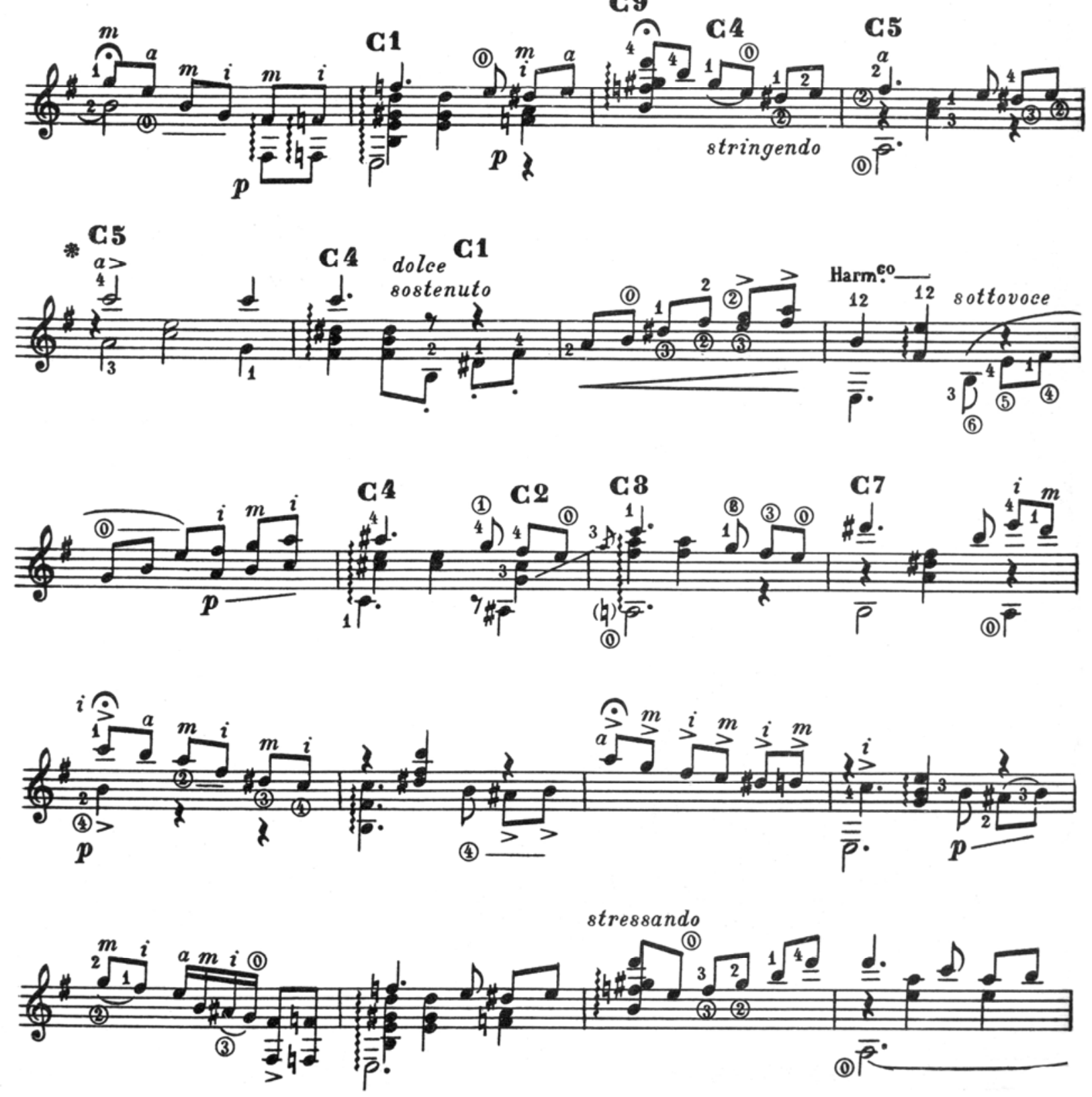

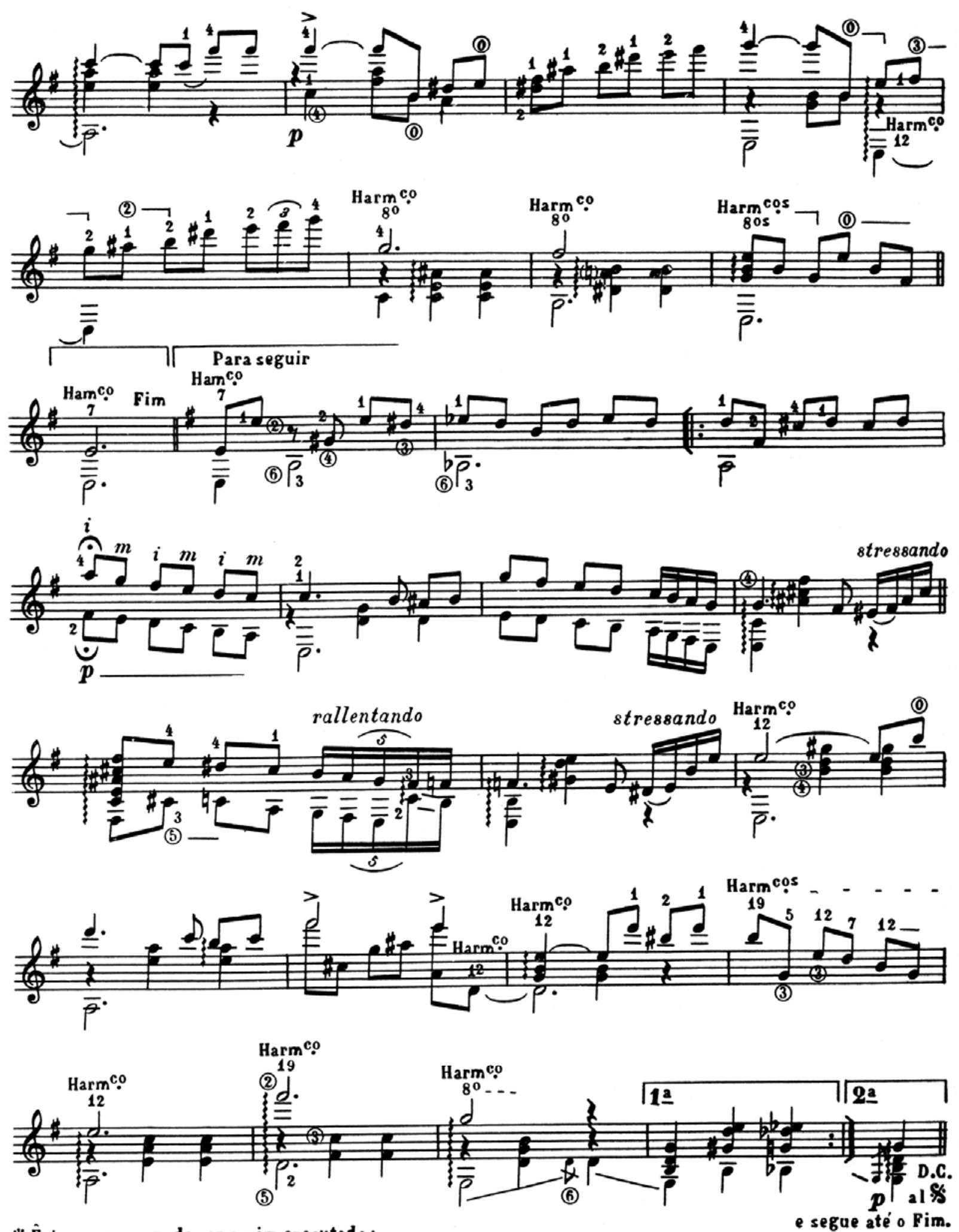

* Êste compasso pode ser assim executado:

e segue até o Fim.

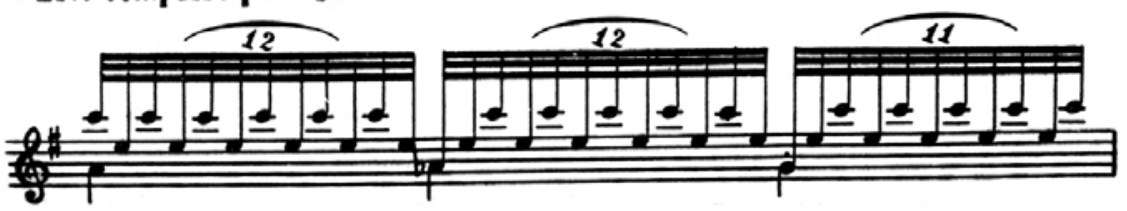




\subsubsection{Confeccionadas por Nélio Rodrigues}

\section{Ansiedade}

Nélio Rodrigues a classifica como um prelúdio. Tem com centro tonal em lá menor. É nítida a intenção do autor de transmitir a ansiedade do título da peça, utilizando progressões de acordes, em sua maioria dissonantes. O compositor alterna estas progressões com escalas ascendentes que levam a uma nova progressão, aumentando gradativamente a tensão. A peça termina em um acorde com terça de picardia.

\section{Batuque}

Composto em parceria com João dos Santos, o Batuque é um choro em duas partes, que apresenta forma ternária simples ABA. Com a sexta corda afinada em ré, trata-se de um choro bastante convencional, com a parte A na tonalidade de Ré Maior e parte B na relativa menor.

Destacamos o efeito nos compassos 6 e 7, onde as notas duplas tocadas com o polegar da mão direita desenvolvem uma melodia descendente e a harmonia não sofre mudanças; o uso dos ligados com cordas soltas que surgem em outras peças (c.20 e 28) e os ligados duplos (c.24).

Estrutura formal:

$$
\begin{aligned}
& \text { A - comp. } 1 \text { ao primeiro tempo do comp. 19; } \\
& \text { B - 2a metade do comp. } 19 \text { ao comp. 36; } \\
& \text { A - comp. } 1 \text { ao comp.16; } \\
& \text { Coda - comp. } 37 \text { e } 38 .
\end{aligned}
$$




\section{Choro Seresteiro}

Em parceria com Eduardinho da Piedade, o Choro Seresteiro é composto em forma de um rondó ABACA e conforme o título anuncia, tem andamento lento. A parte A e a parte B apresentam melodias evocativas das serestas, na tonalidade de mi menor. Notase o uso das sextas (c.10) e dos diálogos entre as melodias do baixo e da região aguda.

Esta peça nos parece ser do período de juventude de Othon Salleiro, pois trata-se de um choro com ritmo da habanera, característica do período inicial do desenvolvimento do gênero, ainda sem muitas síncopas e notadamente na parte $\mathbf{C}$, é mais marcante esta caracterização (c. 49-61).

Estrutura formal:

$$
\begin{aligned}
& \text { A - comp. } 1 \text { a primeira metade do comp. 16; } \\
& \text { B - 2a metade do comp. } 16 \text { ao comp. } 32 ; \\
& \text { A - comp. } 33 \text { ao comp. } 48 \text {; } \\
& \text { C - comp. } 49 \text { ao comp. } 61 ; \\
& \text { A - comp. } 62 \text { ao comp. } 77
\end{aligned}
$$

\section{Dança Árabe}

Peça característica que apresenta uma introdução de oito compassos, com indicação de andamento andante, alternando ligados e escalas. A música, em mi menor, apresenta apenas uma parte com melodia e é acompanhada por um pedal com a nota mi, sexta corda que aparece por quase toda a música.

Estrutura formal: 
I ntrodução - comp. 1 ao comp. 8;

A - comp. 9 ao comp.21;

A' - comp. 22 ao comp. 44.

\section{Miudinho Chegadinho}

Apresenta a scordatura da viola caipira (cebolão em ré), conforme já vimos no tópico sobre os estilos da música de Salleiro. Apresenta forma ABCDA. Na tradição das modas de viola, a peça contém os elementos já vistos: o uso das campanellas durante praticamente todo o corpo da peça, das terças (c.5, 18, 19), das décimas (c.50, c.58), dos acordes rasgueados (a partir do c.66), além das seqüências de mordentes (c.12-13; 93-94) e do uso recorrente dos ligados (c. 10, 22, 30, 44, 90-93).

Estrutura formal:

$$
\begin{aligned}
& \text { A - comp. } 1 \text { ao comp. } 17 ; \\
& \text { B - comp. } 18 \text { ao comp. } 33 ; \\
& \text { C - comp. } 34 \text { ao comp. 49; } \\
& \text { D - comp. } 50 \text { ao comp. } 81 ; \\
& \text { A - comp. } 81 \text { ao } 97 ; \\
& \text { Coda - comp. } 98 \text { ao } 101
\end{aligned}
$$

\section{Sonhando na Rede}

Peça feita em parceria com J oão Pernambuco, Sonhando na Rede é um choro em duas partes em forma ABA. Choro com linguagem bastante tradicional, a parte $\mathbf{A}$ está na tonalidade de lá menor e B apresenta-se na tonalidade de Lá Maior. 
Notamos a seqüência cromática descendente de acordes diminutos (c.7-11 e 24-25), característica marcante na produção dos dois violonistas.

Estrutura formal:

A - comp. 1 a primeira metade do comp. 17;

B - 2a metade do comp. 17 ao 36 ;

A - comp. 1 até do comp. 14;

Coda - comp.37-38. 
41

\section{Ansiedade}

Revisão

Prelúdio

Nélio Rodrigues

Othon Salleiro

Largo $\quad:=52$

(Senza rigore di tempo)
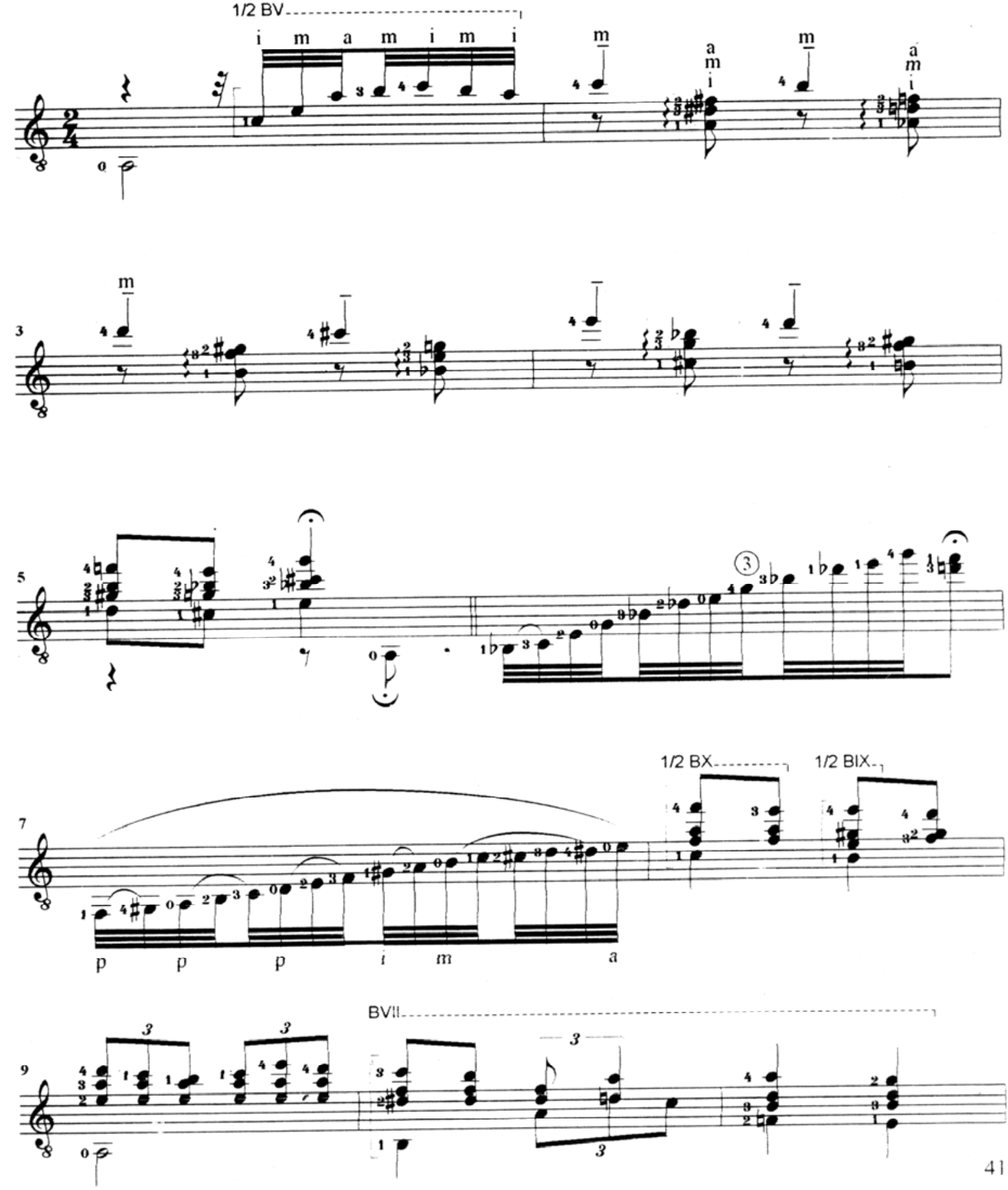

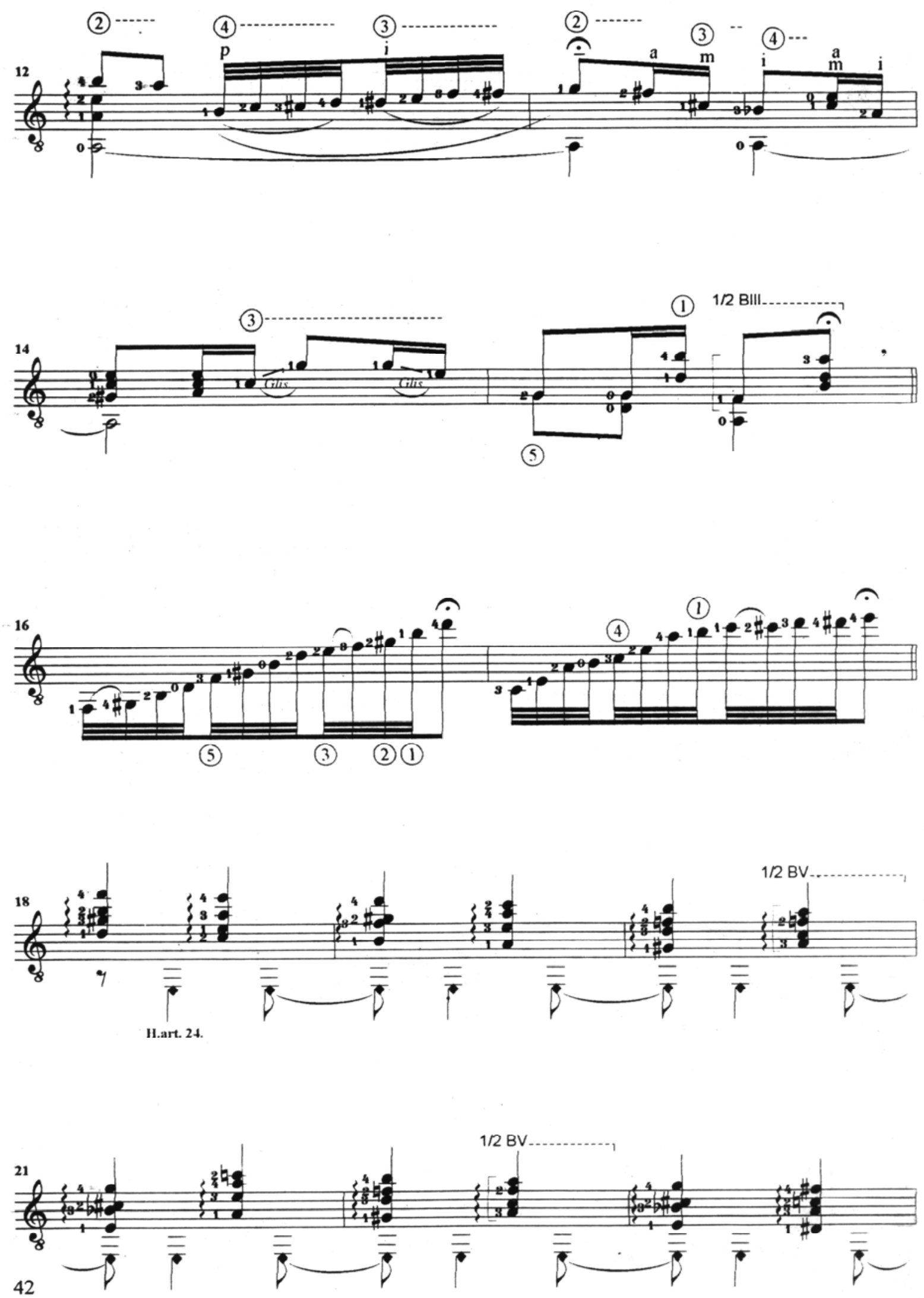
43
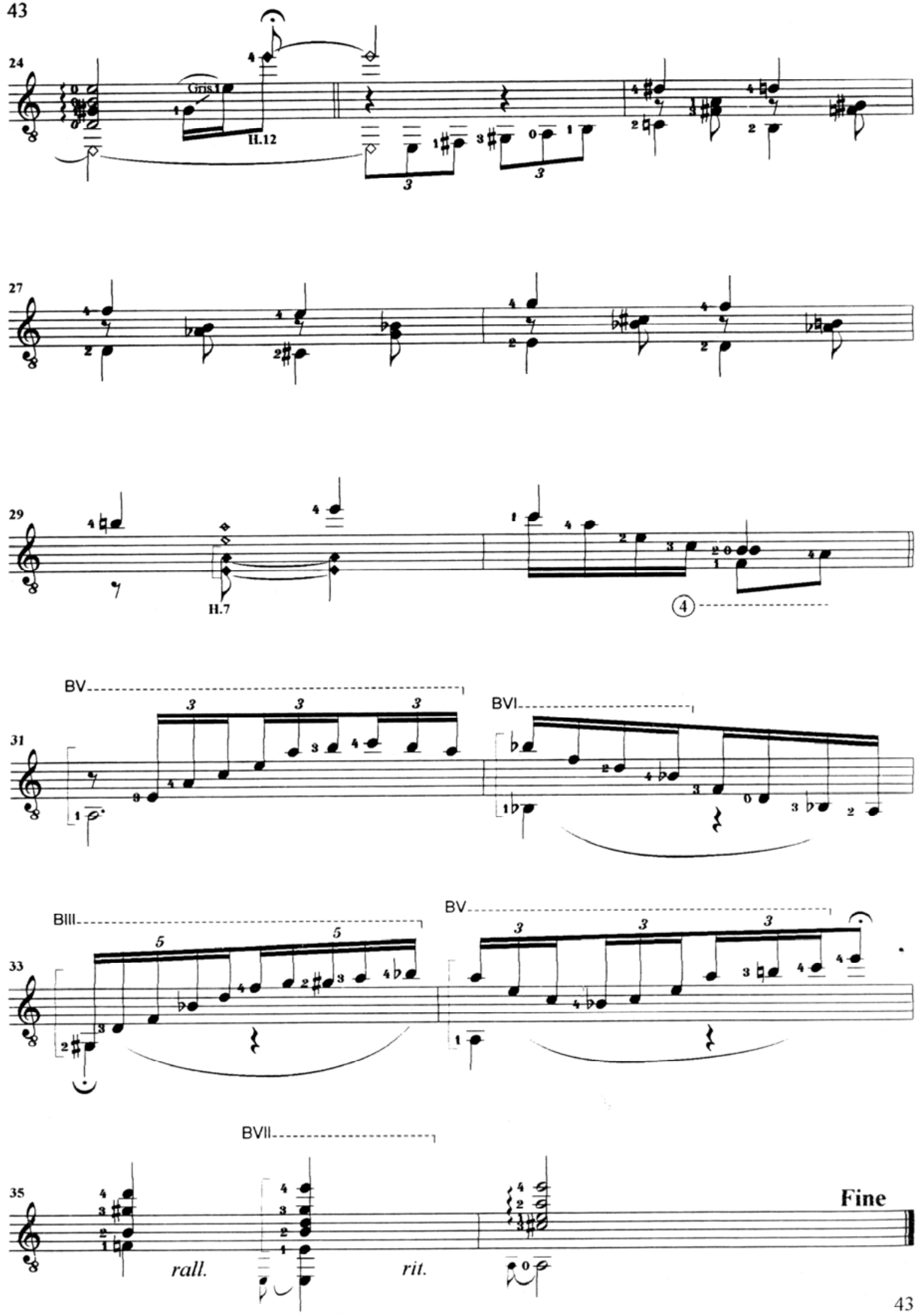
Allegreto $\quad \cdot=92 \quad \&$
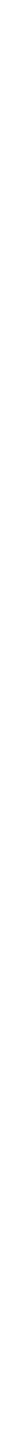

To Coda
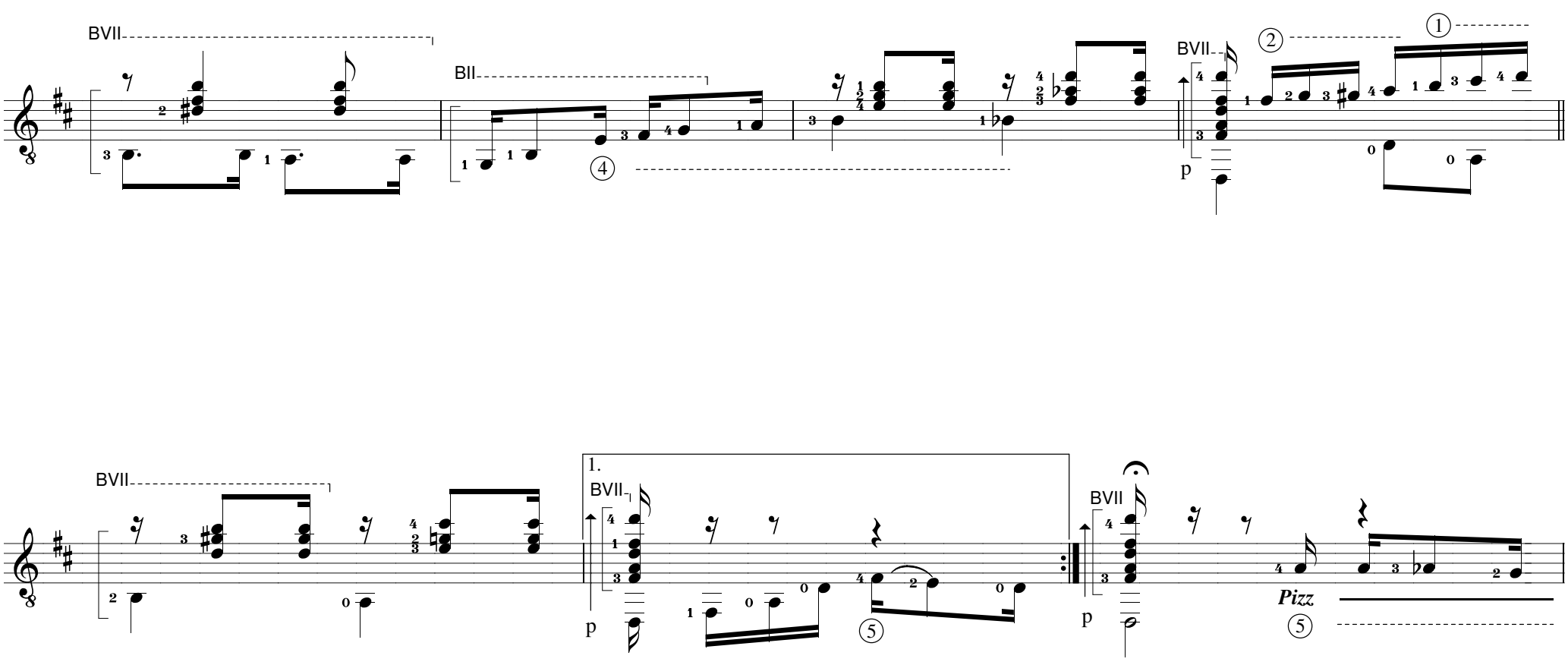
138

Chôro Seresteiro

Anotado no Rio de Janeiro por

Eduardinho da Piedade

Nelio Rodrigues

Othon Salleiro
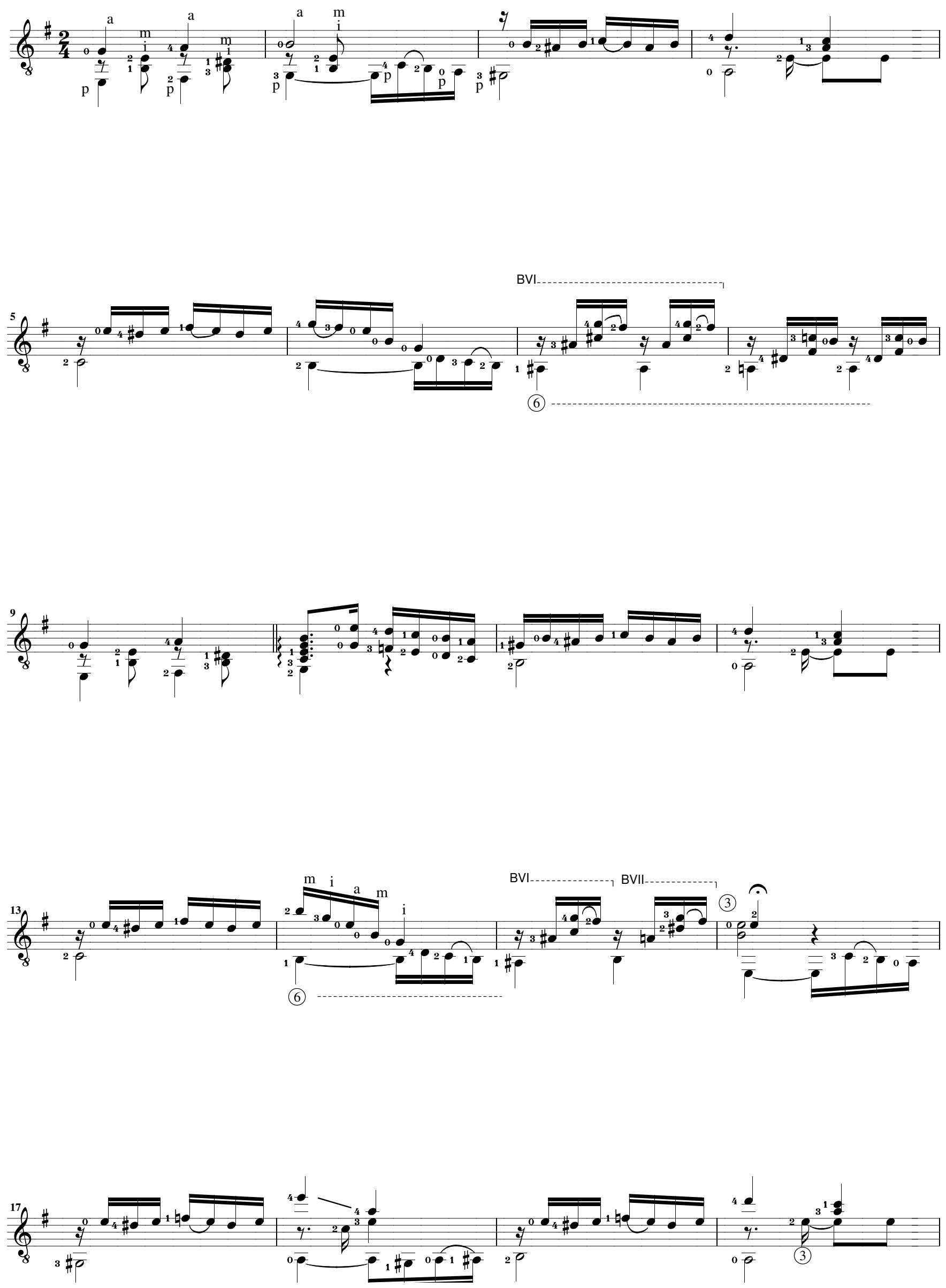
89 (1)

BVI

BIV

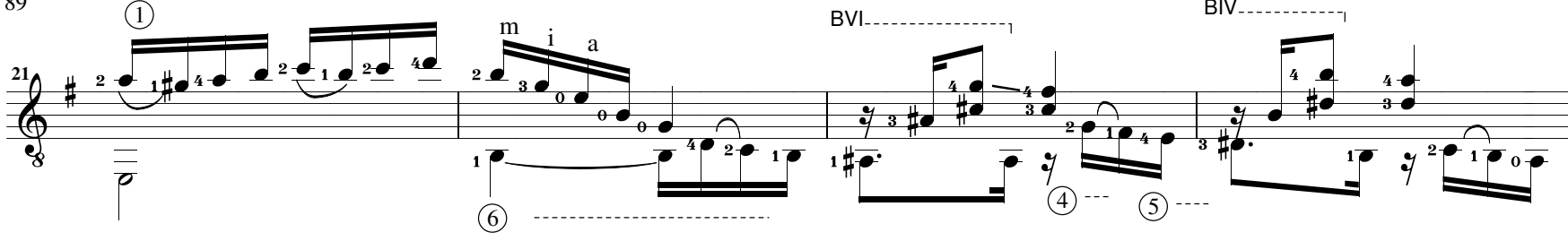

Q6

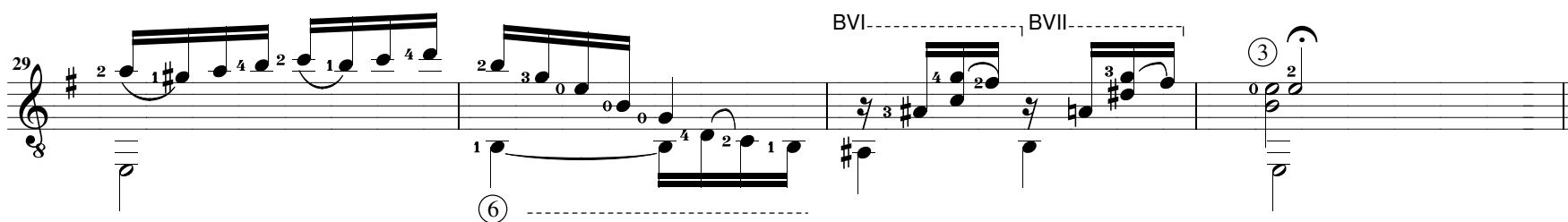

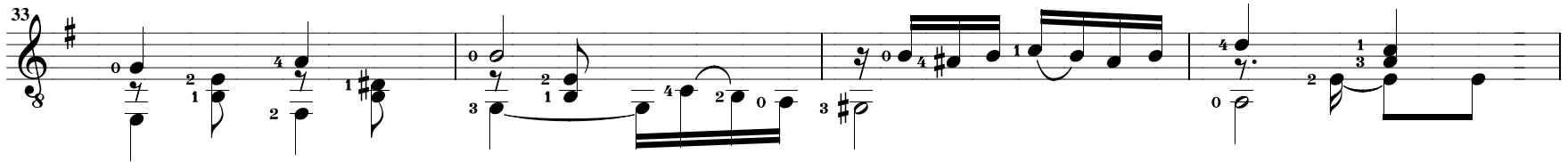

BVI

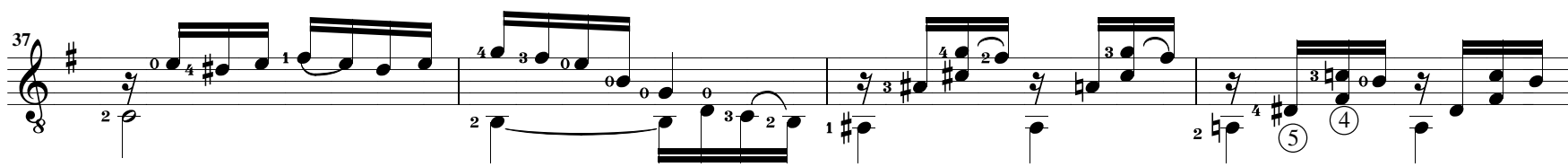

(6)

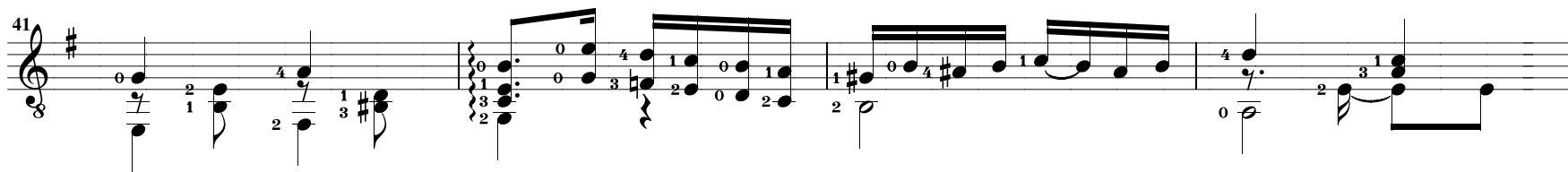

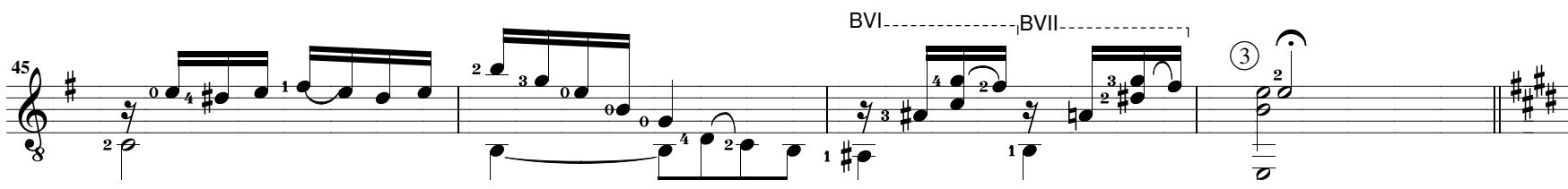



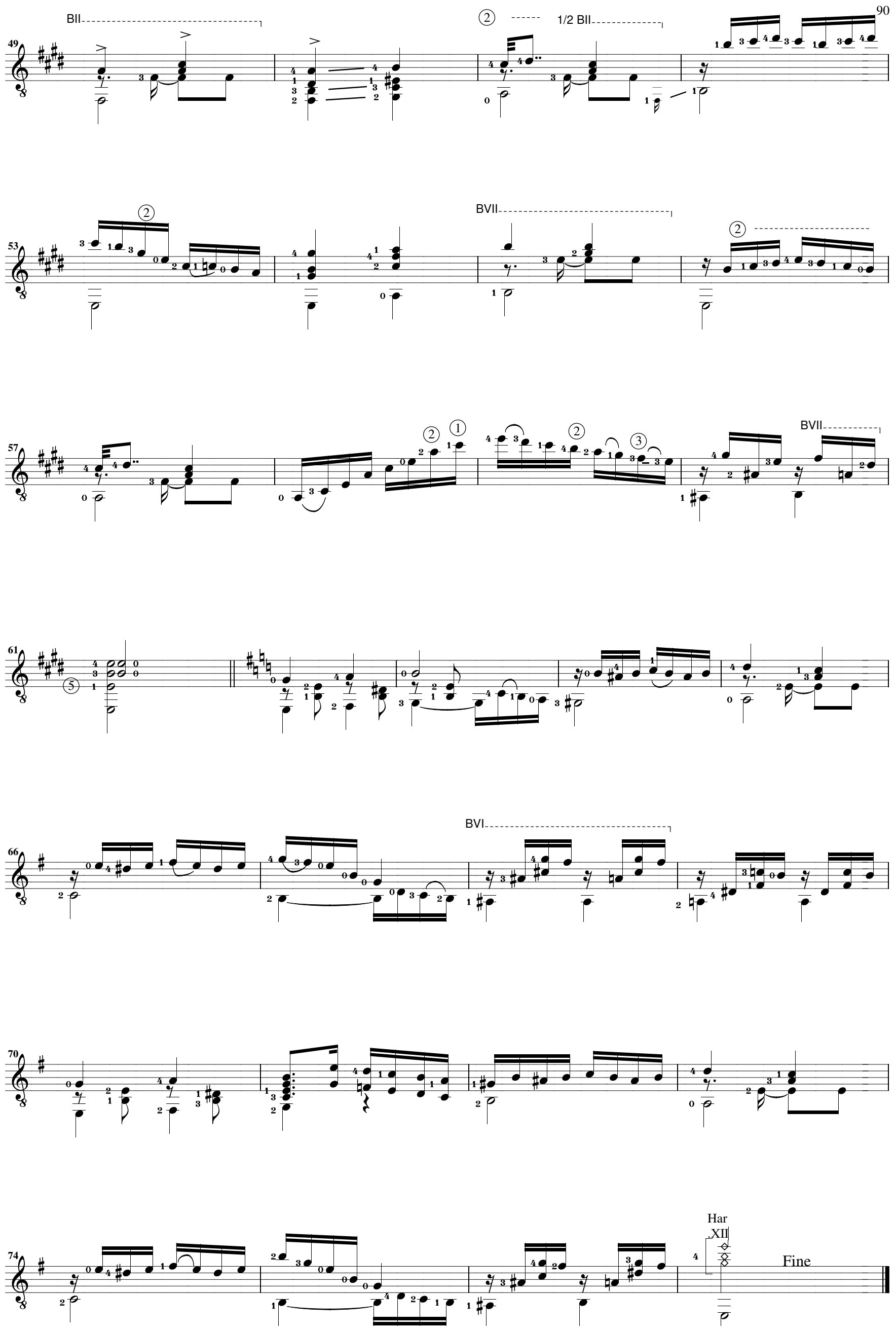
Nélio Rodrigues Introdução
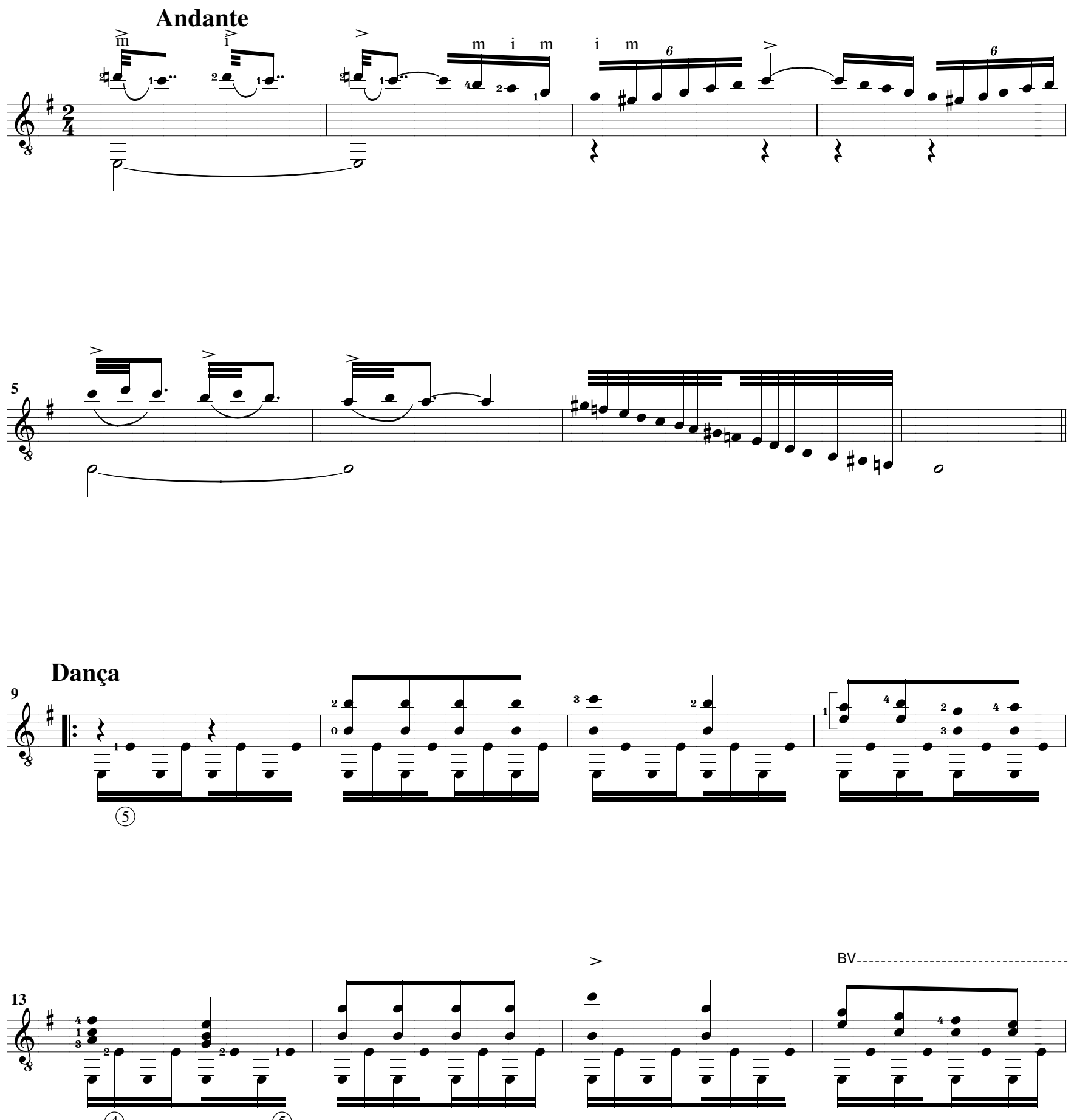

(4)

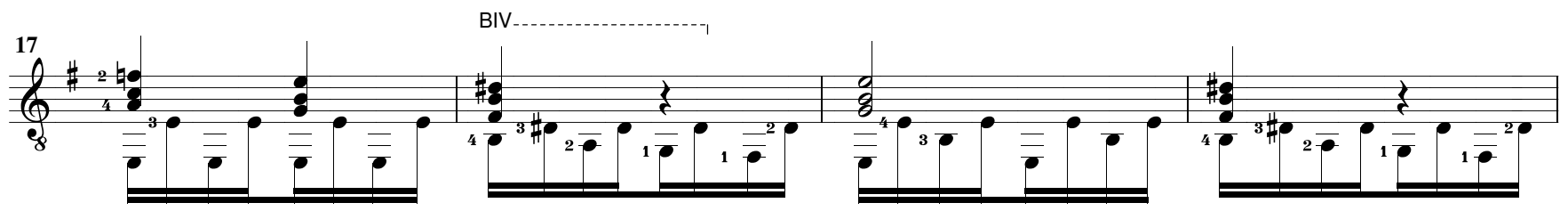




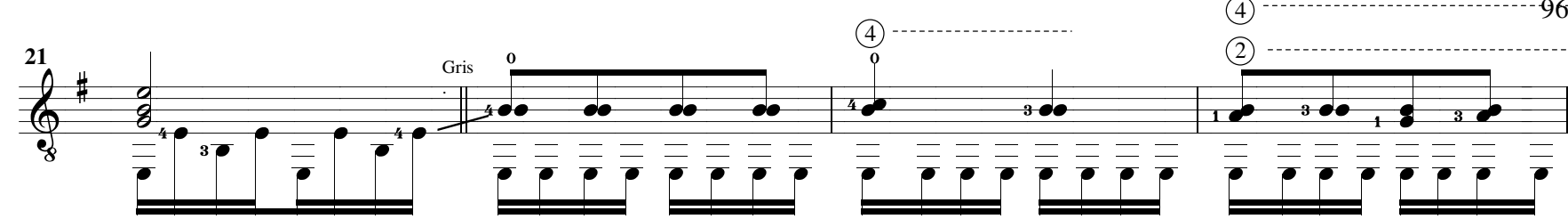
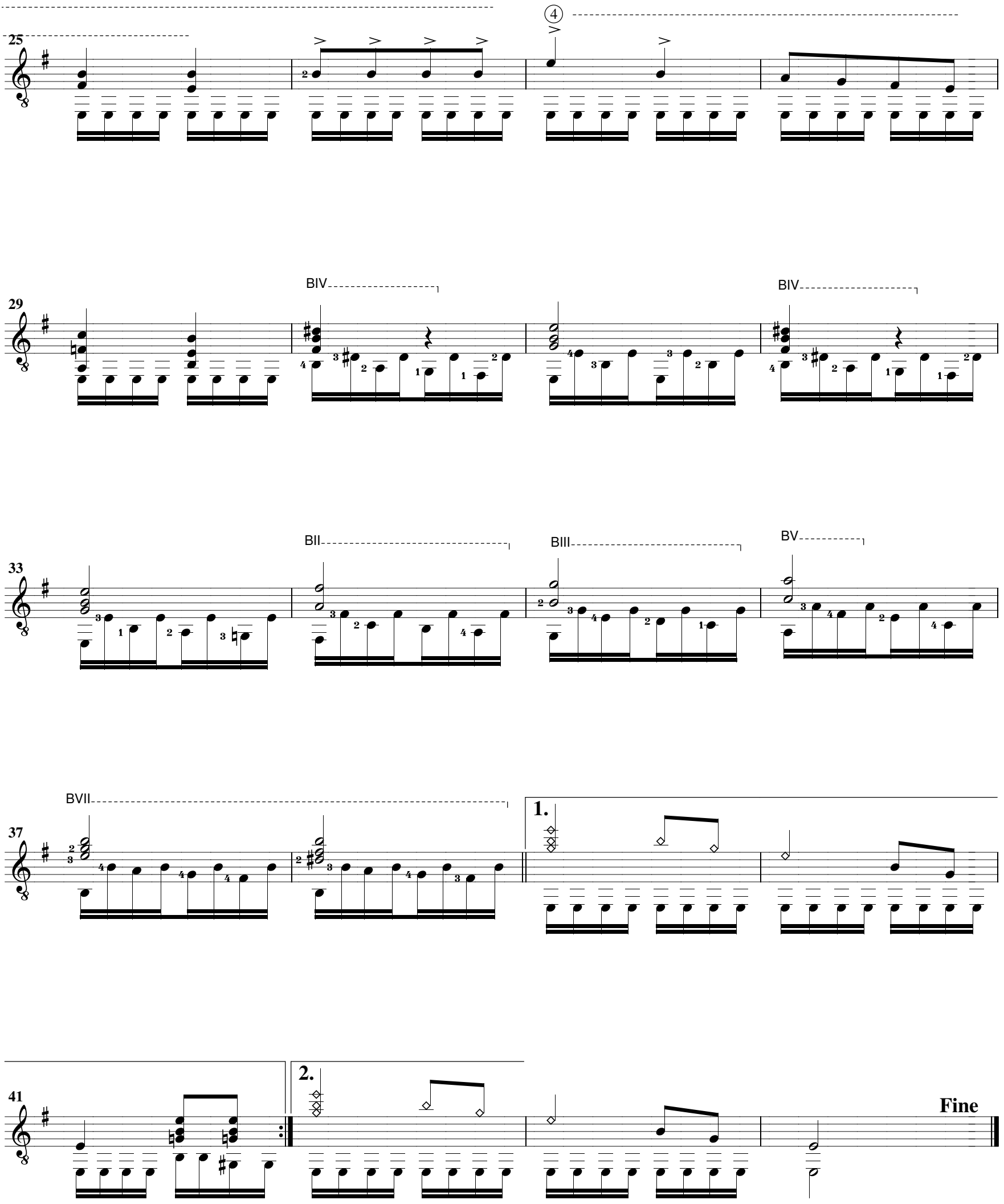


\section{Miudinho Chegadinho}
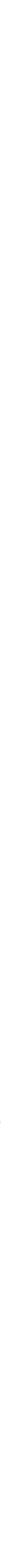

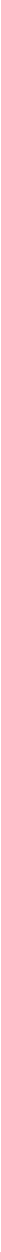

(5)
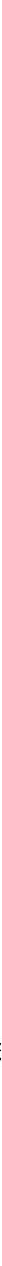


\subsubsection{Confeccionadas para a Dissertação}

Tendo sido o LP Violão Brasileiro de Othon Salleiro o ponto de partida para nosso escrutínio, valemo-nos da opinião de Nélio Rodrigues citada acima: “Hoje eu acharia legal alguém fazer um trabalho pelo disco", e realizamos a transcrição de dezesseis músicas a partir das gravações de Othon Salleiro, sendo nove partituras do LP supracitado, seis músicas extraídas da gravação da RGE e uma música a partir da gravação de Nicanor Teixeira, a Berceuse.

As seguintes partituras foram digitalizadas de manuscritos para a presente pesquisa: Prelúdio Carioca, Diálogo Amoroso, Prece e Cavaquinho em Serenata, anotadas por Nicanor Teixeira; Sonho de Cavaquinho, revisão feita a partir do manuscrito do compositor e Reminiscências Cariocas, digitalizada a partir da transcrição de Nicolas de Souza Barros.

As seis peças extraídas da gravação da RGE foram as que resultaram no trabalho mais exaustivo de transcrição, pois a qualidade da gravação é ruim, apresentando variações na rotação, o que dificulta inclusive o reconhecimento da tonalidade.

Outra dificuldade é a que a gravação de algumas peças executadas em alta velocidade, seja pela rotação alterada ou pela própria técnica de Salleiro, resulta, não raro, em uma diminuição na 
clareza das notas, um aumento no ruído produzido pelo ataque das mesmas e em erros de execução. Vale lembrar que são gravações sem masterização, cortes ou correções. Foi necessário, em alguns casos, extrair as notas quando da reexposição do material.

A execução livre, a pulsação variável, a rítmica complexa e as fermatas inusitadas são alguns dos desafios para escrever a obra de Salleiro. Além dos rubatos, encontramos também tempos a mais ou a menos dentro de um compasso. Tentamos ao máximo não mudar as fórmulas de compasso, deixando esta solução para ser utilizada somente como último recurso (Confidências, compassos 27 e 28 e Devaneio, compasso 31, p.e.), por não acreditar que fosse voluntário do compositor tocar um compasso de 4/4 dentro de uma valsa ou 3/4 dentro de um choro. Julgamos que se tratam de lapsos momentâneos na interpretação. Optamos por utilizar muitas vezes a fermata, a tratina e quiálteras, além das indicações agógicas, conforme sábia observação de Nélio Rodrigues:

$\mathrm{Na}$ hora de escrever, você tem que ajustar, ele parava na nota que gostava, daí, você põe uma fermata. Quanto ele tocava, você não conseguia entender muita coisa, com a concepção de frase, você perdia a concepção do compasso, tem tempo a mais, tempo a menos. Ele dá impressão que começa a coisa no ar e não é, é que ele não está pensando na escrita ${ }^{45}$.

\footnotetext{
${ }^{45}$ Entrevista concedida por Nélio Rodrigues. Rio de Janeiro, dez. 2005.
} 


\section{Allegro Caprichoso}

A única obra em forma de estudo localizada na produção de Othon Salleiro. Trata-se de uma peça de fôlego. Mesmo se levarmos em conta a diferença de rotação da gravação, a velocidade com que o compositor executa esta espécie de estudo em arpejos, mesmo nos dias hoje, é digna de nota. O que nos remete a um comentário de Nicanor Teixeira:

(...) Ele (referindo-se a Salleiro) era muito único, diferente. Primeiro que não tinha muita técnica naquela época, a técnica era muito limitada, ele tinha muito mais técnica do que os contemporâneos, acima da média, uma mão esquerda... uma mão direita...Até hoje, se ele pegasse o violão, a gente ia ficar de boca aberta $(\ldots)^{46}$

Allegro Caprichoso tem como inspiração o repertório virtuosístico para violão do período clássico-romântico (fins do século XVIII até meados do século XIX), nos remetendo mais especificamente a J.Kaspar Mertz (1806 - 1856). Trata-se de um estudo em arpejos, com duas partes, forma binária ( $A B)$, na tonalidade de mi menor. Os arpejos aparecem na peça toda e seu fluxo somente é interrompido para a execução de uma escala na ponte, sinalizando a volta para a parte $\mathbf{A}$.

${ }^{46}$ Entrevista concedida no Rio de Janeiro, jul. 2005. 
Na primeira parte é apresentada uma melodia nas notas agudas. Nas notas graves, o intervalo de segunda menor (si-do), com articulação marcato, aparece introduzindo e separando as frases da melodia.

Na parte B, as vozes externas começam a andar juntas e a melodia passa a ser gerada a partir da harmonia. Nota-se novamente a utilização dos acordes dissonantes, que caminham pelo braço do instrumento (a partir do compasso 27). Elemento utilizado como gerador de tensão, que conduz a peça a um grande accelerando até o compasso 43, onde, retornando e afirmando a tonalidade, o compositor finaliza a música em uma sucessão de arpejos em mi menor.

Esquema formal:

A - comp. 1 ao comp. 20;

B - comp. 21 ao comp. 50.

\section{Batuque ou Batucada-Choro}

Um dos mais interessantes choros da literatura do violão popular brasileiro, o Batuque ou Batucada-Choro é um choro com forma de um forma rondó ( $A B A C A)$. O andamento é moderato. $O$ compositor mistura fragmentos melódicos tradicionais do choro com elementos rítmicos do batuque, utilizando rasgueados; percussão no instrumento e campanella, criando um universo sonoro peculiar. 
A primeira frase, de caráter rítmico acentuado, fará parte da segunda frase de $\mathbf{A}$ (c.15). Em sua reexposição, onde aparece de forma variada, a frase inicial é feita de maneira inventiva, sem pinçar as notas. O batuque aparece alternando tamboras ${ }^{47}$ e outras percussões no tampo do instrumento (c.78).

A parte A aparece reexposta duas vezes. Na segunda vez, o compositor não reapresenta a introdução, utilizando uma ponte com motivo rítmico feita com a nota si (comp.43). Notamos as pequenas variações, características do estilo de Salleiro, em alguns trechos das reexposições nos compassos 25-26; 56-57 e 100-101 e 20-21; 52-53 e 96-97.

Na parte B, o autor apresenta um tema de choro tradicional em duas frases, em Lá Maior, onde a melodia em acordes dialonga com os baixos, recurso bastante característico do gênero.

A parte $\mathbf{C}$, lenta, em mi menor representa, segundo Salleiro, a dança das cabrochas, conforme relata a seguir Nélio Rodrigues:

Salleiro tinha umas birutices, no Batuque, quando passa para o lento, ele falava que era o Ataulfo Alves e as cabrochas, olha só: a saia das cabrochas. Ele era muito lúdico, muito interessante ${ }^{48}$.

\footnotetext{
47 Percussão feita no cavalete do instrumento, com a mão direita.

${ }^{48}$ Entrevista com Nélio Rodrigues. Rio de Janeiro, dez. 2005.
} 
Esquema formal:

A - comp. 1 a primeira metade do comp. 26;

B - 2a metade do comp. 26 até comp.42;

Ponte - comp.43;

A - comp. 43 até do comp.58;

C - comp. 59 a segunda metade de 78;

A - anacruse de comp. 80 até do comp. 103.

Esta peça foi dedicada ao renomado violonista espanhol Narciso Yepes (1927-1997), segundo nos conta Nélio Rodrigues:

(...) O que eu sei que é verdade, é que o Salleiro dedicou a Batucada ao Yepes, isto o Yepes me contou, e foi uma coisa pública, mas não tinha escrito e o Yepes não acertou aquela batucada, por isto não tocou, o espanhol ficou doido, não tinha partitura, tinha que guardar na memória.

\section{Berceuse}

Apesar do nome, Berceuse é uma espécie valsa de salão, nos faz lembrar as novamente a influência exercida por Agustin Barrios. A partitura foi extraída da gravação de Nicanor Teixeira ${ }^{49}$.

A forma da peça é ABACA. A e B estão na tonalidade de ré menor e C em Ré Maior. Na parte A, há a exposição do tema principal, dançante. O tema que aparece em anacruse, surgindo em suspenso, dá impulso à valsa em andamento allegro.

As partes B e C são feitas com a melodia em harmônicos artificiais na maior parte de sua extensão e a harmonia em tríades

\footnotetext{
${ }^{49} \mathrm{O}$ Violão Brasileiro de Nicanor Teixeira. Nicanor Teixeira, 1977. Rio de Janeiro. Independente s/n.
} 
marca o ritmo da valsa. Estas partes assemelham-se pelo uso deste recurso às seguintes composições de Agustin Barrios: Vals op. 8 no 4, Mazurka Appassionata e El sueno de la muñequita. No entanto, Salleiro vai explorar de forma mais profunda este este artifício, utilizando-o à exaustão.

Esquema formal:

$$
\begin{aligned}
& \text { A - comp. } 1 \text { ao comp. } 31 \text {; } \\
& \text { B - comp. } 32 \text { ao primeiro tempo do comp. } 50 \\
& \text { A - segunda metade do comp. } 50 \text { ao comp. } 80 \\
& \text { C - comp. } 81 \text { ao comp. } 112 \\
& \text { A - comp. } 1 \text { ao comp. } 31 \text {. }
\end{aligned}
$$

Sobre Berceuse, Regina Salleiro, a filha de Salleiro recorda:

Tem uma valsinha, que ele sempre contou para a minha mãe que compôs para mim. Um dia ele foi para a TVE e tocou esta música, e ele contou: 'esta música eu fiz para uma criança recémnascida'. Minha mãe falou: 'olha, é minha filha', toda empolgada, e ele foi falando: 'eu vi a criança, com a mãe, debaixo do viaduto, com a criança no colo' (risos). Pode ter sido os dois, ele viu a criança na rua e em casa ele tocava para mim. Na hora a gente não entende depois a gente vai vendo que faz parte do show, é assim mesmo ${ }^{50}$. 


\section{Cavaquinho em Serenata}

Tem o subtítulo de maxixe e está dedicada a J oão Pernambuco na partitura anotada por Nicanor Teixeira. Como o título anuncia, a peça sugere a imitação de um cavaquinho, onde se utiliza a técnica de rasgueados em quase todo o corpo da peça, intercalados por melodias feitas com o polegar. Algumas vezes estas melodias nos graves são executadas com a técnica do pizzicato (c. 4; 6).

Sua forma é a tradicional ternária simples ABA. A parte $\mathbf{A}$ é escrita na tonalidade de Lá Maior e a segunda parte na relativa menor.

Excetuando-se a técnica dos rasgueados, que J oão Pernambuco não tinha por hábito utilizar, esta composição apresenta similaridades com o estilo do violonista pernambucano. A melodia surge da harmonia e há o uso dos acordes fixos que caminham pelo braço do instrumento, o mesmo artifício que foi explorado ao extremo por Heitor Villa-Lobos na sua obra para o violão.

Esquema formal:

A - comp. 1 a primeira metade do comp. 16;

B - comp. 18 até comp.33;

A - comp. 1 até do comp.15;

Final - comp. 17. 


\section{Chimarrita}

A chimarrita, chimarrete ou chama-rita, é uma dança de origem portuguesa. Foi trazida da Ilha da Madeira e dos Açores para o sul do Brasil e dali irradiada para a Argentina, onde se popularizou. De São Paulo até o Rio Grande do Sul constituindo o fandango ${ }^{51}$.

No Rio de Janeiro, era dançada nas festas de Nossa Senhora da Penha. "Também denominada de limpa-banco, pois diziam que, ao ouví-la, ninguém ficava sentado sem dançar" 52.

A composição de Othon Salleiro revela o universo da viola do sul do país, sem que, contudo, possamos afirmar que se trate de uma chimarrita, uma vez que a fórmula de compasso desta obra é (6/8 e 3/4) diferente das chimarritas tradicionais que são escritas em compasso 2/4.

Esta peça apresenta uma estrutura simples, na tonalidade de Sol Maior, sem maiores movimentos harmônicos. Apresenta caráter folclórico, dançante, com andamento rápido.

Mais uma vez é da harmonia que é derivada a melodia. Mais do que temas, ouvimos diversos climas. Parece-nos mesmo que a música pode servir de base para uma coreografia.

Entre os recursos expressivos utilizados para estas ambientações, nota-se o uso de rasgueados e da técnica do trêmolo

\footnotetext{
${ }^{51}$ Desde o Rio Grande do Sul até São Paulo, o Fandango é um conjunto de danças com as mais variadas coreografias e também denominação para festa, folguedo nestas mesmas regiões. In: CASCUDO, Luis da Câmara. Dicionário do Folclore Brasileiro. 11a ed. São Paulo: Global, 2002, 225. 52 Idem, p.131.
} 
nos primeiros compassos da música, a utilização de melodias em harmônicos (18-25, 35-38, 43-50) e das terças (c.33). Destacamos os compassos 35-42, onde a utilização da campanella resulta em uma solução diferente no acompanhamento da melodia que é exposta em harmônicos e reapresentada com notas naturais. Esquema formal:

I ntrodução - comp. 1 ao comp. 17;

A - comp. 18 ao comp. 50;

Coda - comp. 51 ao comp.68.

\section{Coco-Baião}

Coco-Baião possui um subtítulo curioso: Nem a Cumadre Escapa, referindo-se com malícia ao caráter dançante da peça. Composta de duas partes contrastantes, em forma ABA.

A parte A apresenta caráter rítmico, na tonalidade de Mi Maior e a parte B caráter dolente, em mi menor. A introdução da peça é feita em tâmboras e percussão com anular da mão direita no tampo do violão.

Notamos a utilização rasgueados (comp.16-18), mesclados com mordentes que o compositor utiliza para, encorpando o movimento rítmico, chegar ao clímax da parte $\mathbf{A}$, no compasso 18.

Na parte B, um choro de caráter dolente, o autor faz uso novamente das cordas soltas, nas campanellas, para acompanhar 


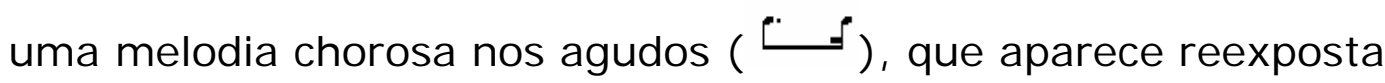
oitava abaixo.

Esquema formal:

I ntrodução - comp. 1 ao comp. 5;

A - comp. 6 ao comp.22;

B - comp. 23 ao 41 ;

I ntrodução - comp. 42 ao comp. 46;

A - comp. 6 ao 20 e final comp. 47 e 48.

\section{Confidências}

Confidências é a obra em que Othon Salleiro utiliza mais a fundo o recurso das campanellas. De caráter recitativo, apresenta duas partes em forma ABA. A melodia na região grave, de caráter solene, é acompanhada por harmonias em campanellas.

Destacamos a mudança de caráter no compasso 27 e 28, onde o autor, utilizando uma seqüência de décimas (recurso recorrente, conforme pudemos observar), muda abruptamente do compasso $3 / 2$ para o compasso $4 / 4$.

Esta obra apresentou-se particularmente problemática na questão da grafia rítmica. Devido à sua interpretação livre, optamos pela utilização de quiálteras, de três e de cinco notas, pois julgamos ser a forma mais próxima da intenção do compositor, além do uso de tratinas onde o compositor valoriza certas notas.

Esquema formal:

$$
\begin{aligned}
& \text { A - comp. lao segundo tempo do comp.18; } \\
& \text { B - 3o tempo do do comp. } 18 \text { ao } 2 \text { o tempo } \\
& \text { do comp. 34; } \\
& \text { A - 3o tempo do do comp. } 34 \text { ao comp. } 51 \text {. }
\end{aligned}
$$




\section{Diálogo Amoroso}

Choro em duas partes. A primeira parte é um choro lento, com a indicação lento e expressivo, na tonalidade de Ré Maior. A segunda parte é um choro em andamento rápido, allegro, em si menor. A peça nos remete ao estilo composicional do paraguaio Agustín Barrios. A parte A deste choro guarda semelhanças com a parte B do Choro da Saudade, de Barrios:
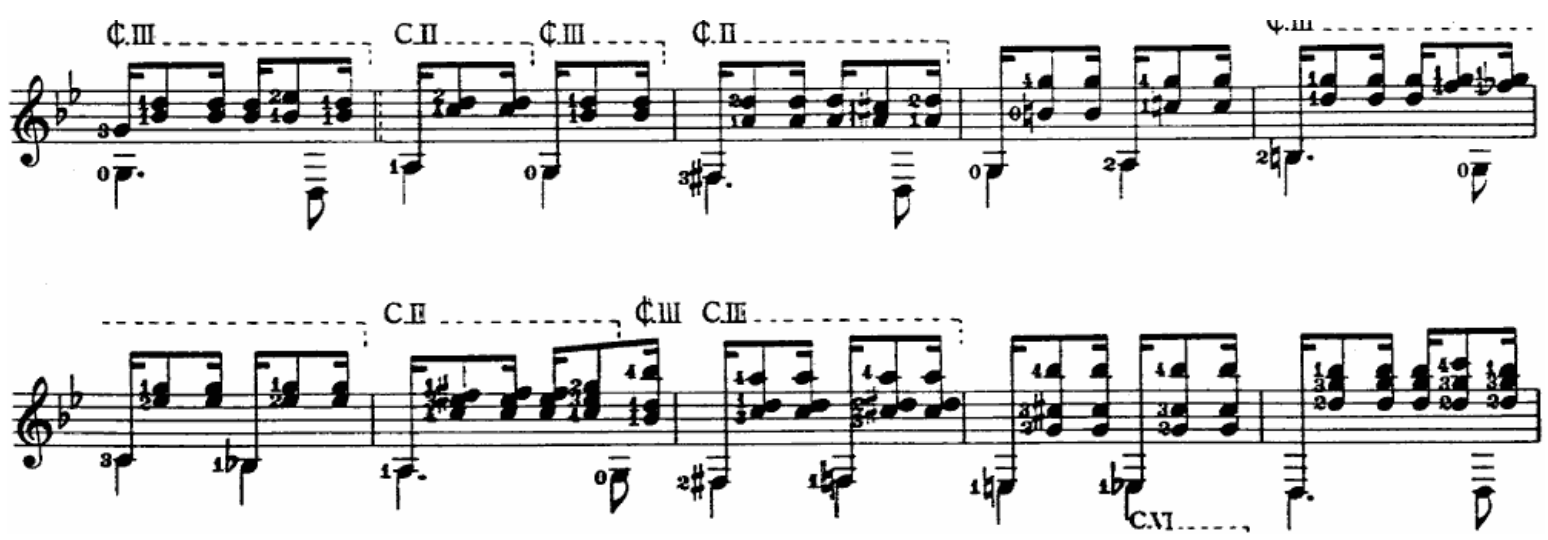

Extrato de partitura 17. Choro da Saudade, Agustin Barrios.

Na parte B, o compositor utiliza a melodia sincopada nos graves, os habituais rasgueados e uma engenhosa campanella com algumas notas em harmônicos naturais (c. 29-30) conferem à síncopa um sabor diferenciado.

Sobre Diálogo Amoroso, Nicanor nos relata abaixo:

(...) Diálogo amoroso, eu cheguei na casa dele, tava o Mario Montenegro ${ }^{53}$, ele (Salleiro) estava sentado e estava tocando Diálogo Amoroso.

\footnotetext{
${ }^{53}$ Mario Montenegro, violonista, foi proprietário da Galeria Toda a Música, loja especializada em música, que era localizada no bairro de Copacabana, no Rio de Janeiro. In: revista Violão e Mestres. São Paulo: Edição Giannini. set. 1965, p. 27.
} 
Mostrando este choro, primeiro um adagio, lento e depois um choro rápido:

'Aqui, neste adagio, o sujeito está se declarando, a mulher não quer, não quer, mas ele continua fazendo as declarações. E a segunda parte já é indecência, os dois se embolam pelo chão'.

Era muito engraçado. Porque a segunda parte era cheia de baixarias, ele dava aquela gargalhada ${ }^{54}$.

Esquema formal:

$$
\begin{aligned}
& \text { A - comp. } 1 \text { ao comp. } 20 \\
& \text { B - comp. } 21 \text { ao comp. } 39 \\
& \text { A - comp. } 01 \text { ao comp. } 20
\end{aligned}
$$

\section{Devaneio ou Conversando com o infinito.}

No trabalho de edição de Nélio Rodrigues esta peça aparece com o título de Conversando com o infinito. Na gravação da RGE, a mesma peça tem o nome de Devaneio. Rodrigues a classifica como uma Romanza.

Escrita em forma livre, tem como tonalidade central mi menor. O motivo melódico aparece primeiramente na região média do instrumento e, no compasso 19 reaparece nos graves de maneira mais enfática.

Notamos o uso das décimas que é bastante recorrente nas obras de Salleiro, como também o uso dos harmônicos artificiais.

A partir do compasso 35, surgem três sucessões de notas em semicolcheias, alterando o caráter exposto até então. Cada sucessão 
encaminha-se mais para o agudo, até chegar à nota mais aguda do instrumento, conduzindo a uma frase de harmônicos fragmentada do tema que finaliza a música.

\section{Excelsa}

Um tipo de valsa brasileira, em forma de tema e variações. O tema é apresentado em Mi Maior; a primeira variação aparece em Si Maior. A segunda variação, em mi menor, utiliza o artifício da melodia em harmônicos, explorando ao máximo tal recurso. A terceira e última variação é feita em uma espécie de trêmolo ${ }^{55}$ diferenciado, uma vez que o indicador (mão direita) pinça uma nota diferente das que são tocadas pelos dedos médio e anular.

Nesta obra temos a impressão que Salleiro "brinca" com o gênero valsa ao tentar moldá-lo para a forma de tema e variações, uma forma tão cara ao período áureo do violão (período clássicoromântico fins do século XVIII até meados do século XIX), de grande desenvolvimento virtuosístico.

Esquema formal:

TEMA - comp. 1 ao comp. 33;

Variação 1 - comp. 34 ao comp.67;

Variação 2 - comp. 68 ao comp. 100;

Variação 3 - comp. 101 ao comp.132;

Variação 4 - comp.133 ao comp. 166.

\footnotetext{
$55 \mathrm{O}$ trêmolo no violão normalmente é uma seqüência de três notas iguais, executadas com os dedos anular, médio e indicador (mão direita), na velocidade rápida, para criar a ilusão de uma melodia de notas longas.
} 
Nicanor Teixeira lembra-se de uma passagem em um sarau na casa de Jacob do Bandolim:

E ali ele criava muito, ele gostava de ser ouvido, tinha muita coisa. Eu me lembro que numa ocasião teve um sarau no J acob, e tinha muita gente, Pixinguinha, Alfredinho do Flautim, César Faria, pai do Paulinho da Viola. E J acob lá tocando e ele chamou o Salleiro para tocar e tava Radamés também. Salleiro tocou Excelsa, era uma coisa impressionante, estava atacado. Quando terminou, a Tia Amélia ${ }^{56}$, pianista, uma mulher nordestina, disse: 'depois de um negócio destes, que é que eu posso dizer? Olha, eu te amo'. Pronto, ficou emocionada, entende? Uma senhora, de idade, Salleiro era fantástico. Ela ficou emocionada ${ }^{57}$.

Em outro momento, questionado sobre sua convivência com

Salleiro, Teixeira ressalta:

Aprendi muito com ele, vibrato, tinha um jogo de mãos, impressionante. Tinha a Excelsa, um jogo de harmônicos, ia tocando, impressionante... ${ }^{58}$

Sobre o disco, O Violão Brasileiro de Othon Salleiro, Ronoel Simões destaca:

\footnotetext{
${ }^{56}$ Amélia Brandão Néri (1897-1983). Nascida em Jaboatão, Pernambuco, pianista e compositora. Começou sua carreira na Rádio Clube de Pernambuco. No Rio de Janeiro foi contratada pela Rádio Mayring Veiga, Sociedade e Clube do Brasil. Deixou as seguintes gravações: Valência/Revoltado. Odeon, 78, 1959. Cuíca no choro/Bom dia Radamés Gnattali . RCA Victor, 78, 1960. Velhas estampas. Odeon, LP, 1959. As músicas da vovó no piano da titia. Odeon LP, 1960. A benção, Tia Amélia. Marcus Pereira. LP, 1980.

57 Depoimento colhido no Rio de Janeiro, dez.2006.

58 Idem.
} 
Ele tocava músicas clássicas, mas ele tocava bem era as músicas dele, ainda bem, era muito difícil, de um grau técnico, Excelsa. Foi uma grande coisa aquela gravação, ainda bem ${ }^{59}$.

Ainda sobre a performance criativa de Salleiro, Nicanor Teixeira revela:

Excelsa, muito bom, valsa brasileira, com ele tocando, sai de baixo, ele era do tipo que tocava e ficava todo vermelho, com lágrimas nos olhos, era fantástico, fazia umas coisas impressionantes, daí, dava risada, era muito gozado, muito bom. A Excelsa é um negócio muito sério, tem uns harmônicos, dava raiva de ver ele tocando, era aquele cara que sempre mudava uma coisa ou outra, e dava uma risada: 'olha, como ficou bonito agora!' 60

Dona Mariazinha Salleiro também se recorda:

Excelsa era difícil - muito linda e eu lembro dele tocando, quando você perguntou qual a música que ele mais tocava, era Excelsa (...) ele dizia que havia feito Excelsa para mim, mas acho que nem me conhecia quando fez (risos) ${ }^{61}$.

\footnotetext{
${ }^{59}$ Entrevista concedida por Ronoel Simões, São Paulo, abril 2005.

${ }^{60}$ Idem.

${ }^{61}$ Entrevista realizada em J acarepaguá, Rio de Janeiro, dez. 2005.
} 


\section{Falando-Ihe de Amor}

Na tradição da valsa brasileira, Falando-Ihe de Amor remete as valsas de Dilermando Reis. Tem forma binária $A B$ e andamento lento. A parte A, na tonalidade de Mi Maior, tem melodia romântica, repleta de portamentos. Nota-se o uso expressivo de arpejos rápidos, quase acordes arpejados (c.7, c. 10, c.35, c. 41) e o aparecimento freqüente de graus conjuntos nos baixos, utilizados também como recurso expressivo. O tema B, de caráter mais movido e mais dramático, apresenta maior movimento harmônico.

Destacamos também o trecho final, a partir do compasso 52 , onde o compositor desenvolve uma coda, que termina em uma seqüência de quartas, algo que não é usual nas valsas deste estilo. Esquema formal:

A - comp. 1 ao comp. 29;
B - comp 30 ao comp. 56 .

\section{Festa do Bonfim}

Espécie de choro maxixado, de caráter virtuosístico.

Alternando as tonalidades de Ré Maior e ré menor, a peça apresenta uma introdução com um trecho virtuosístico de semicolcheias que lembra os estudos técnicos de Francisco Tarrega, durando oito compassos em Ré Maior. Em seguida, háuma seqüência de acordes ainda em Ré Maior onde a melodia dos baixos ( ${ }^{\cdot}$ ) imprime o ritmo para o início da música, agora na tonalidade de ré menor. Apresenta forma ABA, com introdução. 
Foi a peça mais problemática para grafar, seja pela velocidade e falta de precisão da interpretação, seja pela falta de coerência harmônica em alguns trechos (c.16, 17, 18 e 19) e, principalmente, na questão rítmica, pois a falta precisão na execução dificulta a compreensão da intenção do autor. Tentamos nos aproximar ao máximo da execução, mas destacamos problemas, como nos compassos 53 e 59, em que resulta impossível escrever o que o compositor executa.

Chamamos atenção para a campanella dos compassos 22, 38 e compasso 69. Progressões de acordes com melodias no baixo, o baixo com o desenho característico do choro ( ${ }^{*}$ ) e os acordes rasgueados são alternados durante todo o corpo da peça. Esquema formal:

Introdução - comp. 1 ao primeiro tempo do comp. 16;

A - 2a metade do comp. 16 até primeiro tempo do comp.50;

B- 2 a metade do comp. 50 ao comp. 83;

A - 2a metade do comp. 16 até primeiro tempo do comp.45;

Coda - comp. 84 ao comp. 95. 


\section{Luar dos Trópicos}

Valsa lenta, publicada por Nélio Rodrigues como Nocturno Vals.Tem forma ABA, ternária simples. A primeira parte, em lá menor, com melodia molto legata, chorosa, está inserida na tradição das valsas melodiosas brasileiras. Notamos que compositor utiliza a exaustão o artifício dos harmônicos, tanto naturais quanto artificiais, nas partes melódicas principais.

A parte B, tem caráter contrastante, na tonalidade de Dó Maior. Através de uma progressão harmônica, o compositor faz uso de movimentos contrários entre as vozes externas. Esta progressão chega a uma passagem em harmônicos com fragmentos da melodia da parte A, e não é nada mais do que uma ponte ao início, reexpondo a parte $\mathbf{A}$.

Devido à interpretação flexível do autor, surgem alguns problemas na grafia. Foi necessário achar uma alternativa para mesurar as inflexões de tempo da execução para tornar possível a escrita que propormos nos compassos $(6,14,23$ e 48).

Esquema formal:

A - comp. 1 ao segundo tempo do comp. 33;

B - 3o tempo do comp. 33 ao comp.67;

A - comp. 68 ao comp. 101. 


\section{Prece}

Adagio religioso, com caráter dramático, na tonalidade de ré menor, com a sexta corda afinada em ré. A peça é escrita à maneira de um coral a quatro vozes. Mais uma vez o estilo nos remete ao paraguaio Barrios remetendo ao Andante Religioso da música La Catedral.

Conforme narra Nicanor Teixeira, "era um sábado, ele e Othon Salleiro estavam tocando violão, quando tocou o telefone e Salleiro recebe a notícia que sua esposa D. Mariazinha e sua filha Regina haviam batido o carro, voltando da cidade de Rio das Ostras, onde tinham uma casa de praia. Estava tudo bem, haviam batido o carro em uma pedra e não haviam sofrido ferimentos". Segue o depoimento de Teixeira:

Ele sentou e compôs Prece. E eu peguei com ele, fui para casa e escrevi, tenho impressão que ele não sabe que eu escrevi. É um adagio, lento, lindo, uma obra-prima. Linda, linda, linda. Eu tocava ${ }^{62}$.

$\overline{62}$ Em entrevista concedida no Rio de Janeiro, jul. 2006. 


\section{Prelúdio}

Prelúdio é uma peça nitidamente influenciada por Barrios, conforme vimos acima. De andamento moderato, na tonalidade de mi menor, é bastante orgânico do ponto de vista temático. Este prelúdio começa com uma melodia descendente nos graves, que reaparece uma oitava acima. Nos dois casos a melodia é acompanhada por arpejos, onde as duas notas mais agudas, articuladas por ligados, separados por segundas, maiores ou menores, criando outra melodia descendente, conferindo uma grande coesão temática à peça.

\section{Quebra-Coco}

Acreditamos tratar-se de um maxixe. É uma obra com caráter essencialmente rítmico, em forma de um rondó ( $A B A C A)$. Esta composição lembra o estilo de João Pernambuco, onde a melodia é derivada da harmonia.

Notamos a utilização de alguns recursos, tais como: o pizzicato na exposição do tema da parte $\mathbf{A}$ e na primeira frase da parte $\mathbf{C}$; pequenas variações rítmicas nas reexposições da parte A (acordes, arpejos em tercinas, arpejos com fórmulas diversas), os rasgueados (c.73 e 89); stacattos (c.33; 66-67; 74-75; 90-91) e a diminuição do padrão rítmico (c.69-70; 93-94). Estes procedimentos 
enriquecem tanto o ritmo quando o timbre, aumentando o caráter dançante da peça.

Esta foi uma das gravações mais problemáticas para a transcrição, seja pela velocidade da execução ou pela falta de nitidez. Destacamos a passagem dos compassos 14-15; 30-31; 63$64 ; 111-112$, que carece de clareza, de onde somente foi possível extrair as notas na última repetição (c.111-112).

Chamamos atenção para a parte B, composta por dezesseis compassos. As duas frases são apresentadas em progressões harmônicas simples, que demonstram a inventividade rítmicotemática do compositor, utilizando novamente o recurso das campanellas.

Esquema formal:

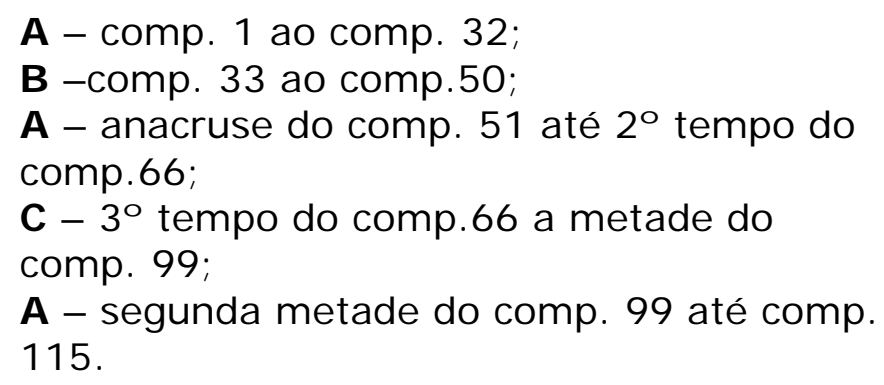

\section{Reminiscências Cariocas}

Choro virtuosístico que apresenta que apresenta a forma de um rondó ( $A B A C A)$.

A parte A, em mi menor, começa com uma escala ascendente nos graves. Em seguida há um grande glissando (c.2) e uma 
progressão descendente em arpejos, que conferem a peça um movimento frenético, através da evolução de melodias nos baixos acompanhadas pelas campanellas. Sem repouso, depois de uma ponte nos graves (c.18), inicia-se o B, agora em uma progressão de arpejos ascendente e em nova tonalidade (Mi Maior). Novo material temático aparece exposto no compasso 21 e deriva-se uma melodia sincopada nos graves, intercalada com rasgueos e acordes, imitando um batuque que conduz à reexposição de $\mathbf{A}$.

Na parte $\mathbf{C}$, de caráter rítmico, apoiado em harmonias dissonantes e síncopas nos graves, rasgueos e campanellas, o compositor desenvolve um interessante jogo de síncopas entre as vozes, que vai aumentando a densidade rítmica até o final. Esquema formal:

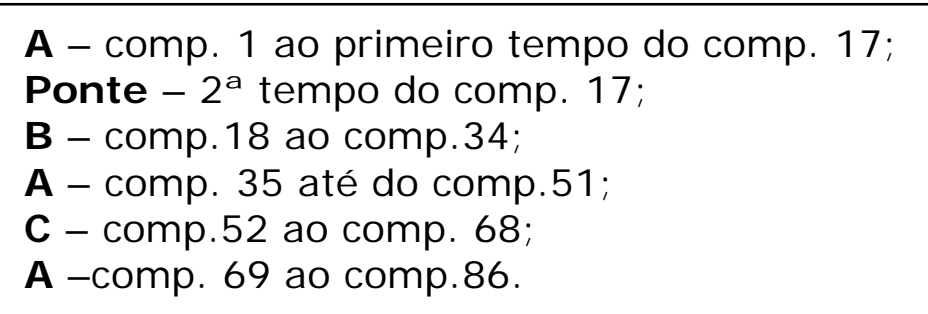

\section{Repinicado de Viola}

Scordatura: cebolão em ré.

Sobre o repenicar, encontramos no Dicionário Musical Brasileiro, de Mario de Andrade: “Executar no instrumento sons rápidos. Se aplica especialmente à viola, entre o povo". 
Com andamento mais movido do que as toadas Viola da Saudade e Toada Sertaneja, o Repinicado de Viola apresenta o universo da viola caipira através de motivos característicos: a utilização das terças (c.6, 18-19; 89-91); melodias utilizando a técnica dos ligados (c. $21,35,43,85,107,93$ ); oitavas paralelas (c. 49, 51, 57, 59, 67, 73); motivos gerados por acordes arpejados (c. $1,2,13,22,38,61,69,99,100)$ e o já recorrente uso das campanellas.

Esquema formal:

$$
\begin{aligned}
& \text { A - comp. } 1 \text { ao primeiro tempo do comp. } 16 ; \\
& \text { B - Segundo tempo do comp. } 16 \text { até comp. } 32 ; \\
& \text { C - comp. } 33 \text { ao comp. } 48 \text {; } \\
& \text { D - comp. } 49 \text { a primeira metade do comp. } 80 ; \\
& \text { B' - segunda metade do comp. } 80 \text { até comp.97; } \\
& \text { A - comp. } 98 \text { ao comp. } 112 \text {. }
\end{aligned}
$$

\section{Sonho de Cavaquinho}

Choro lento em forma de um rondó ( $A B A C A)$, sendo a primeira parte um lamento evocativo na tonalidade de mi menor. O tema da parte B possui caráter cantabile, com uma seresta, na tonalidade homônima maior.

A melodia da peça é acompanhada de acordes rasgueados que imitam um cavaquinho, entremeados com arpejos ponteados.

Em um estilo que nos remete a Ernesto Nazareth, a terceira parte, na tonalidade de Sol Maior, apresenta uma progressão descendente com motivo rítmico característico dos tangos brasileiros do compositor de Odeon.

Esquema formal: 
A - comp. 1 a primeira metade do comp. 17;

B - comp. 18 ao comp. 35;

A - comp. 36 a $1^{\text {a }}$ metade do comp.51;

C - 2a metade do comp.51 ao comp.69;

A - comp. 1 a primeira metade do comp.15;

Final - compasso 70.

\section{Ternura}

Obra única, pelo que temos notícias, na literatura do violão brasileiro: apresenta a inusitada scordatura em Ré Maior (1aㅡ ré, 2aㅡ lá, 3ạ fa\#, 4a ré, 5a sol, 6a ré).

Em sua edição, Nélio Rodrigues a classificou como um canção. A peça utiliza ao máximo as cordas soltas e os harmônicos naturais, fazendo com que as notas fique ressoando. A melodia de caráter melancólico remete às miniaturas para piano do período romântico.

Esquema formal:

I ntrodução - comp.1 ao penúltimo tempo do comp. 5;

1a Frase - último tempo do comp. 5 até comp.18;

2a Frase - comp.19 ao comp. 32;

Coda - comp. 33 ao comp. 38. 


\section{Toada Sertaneja}

Scordatura: cebolão em ré.

Composição bastante simples, com forma $A A^{\prime}$. Depois de três compassos de acordes em harmônicos (I-V-I), há uma frase de oito compassos imitando o ponteado da viola caipira.

O tema principal é apresentado na região mais aguda do instrumento. Este tema reaparece na música Viola da Saudade, conforme veremos adiante. Trata-se uma melodia cantabile que lembra o tema do dueto Un Dì Felice, Etérea, da ópera La Traviata, de Giuseppe Verdi (1813 - 1901) (c.13-19).

Nos próximos compassos, em resposta ao tema nos agudos, o autor nos apresenta elementos típicos das modas de viola, intercalando acordes arpejados e rasgueos com uma frase bastante familiar ao universo da música sertaneja (c. 20-35).

A música repete-se quase idêntica (c.57 apresenta pequena variação), a partir da introdução ponteada. A peça termina com uma coda derivada do motivo da introdução, variado em rasgueos primeiramente e depois em tamboras.

Esquema formal:

I ntrodução - comp. 1 ao comp. 3;

A - comp. 4 ao comp. 11;

$\mathbf{A}^{\prime}$ - comp. 12 ao comp. 35;

A - comp. 36 ao comp. 43;

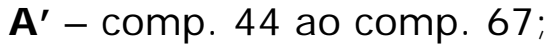

Coda - comp. 68 ao comp. 76. 


\section{Viola da Saudade}

Scordatura: cebolão em ré.

Trata-se de uma toada. A introdução é feita de maneira dolente, através de rasgueados lentos que levam a uma frase característica do universo das modas de viola (c.5).

Depois do aparecimento de uma frase de quatro compassos em terças, o tema central, nos agudos, e a resposta a este tema são quase idênticos aos apresentados na Toada Sertaneja (c.11-31). Nota-se de diferente a inserção de harmônicos e rasgueados mais lentos na Viola da Saudade (c.20, 24; 27, 31, 34).

Os elementos característicos das modas de viola aparecem nos rasgueos lentos (c. 27, 34, 69-71), na utilização das terças (c. 7-9, 75-78), nas progressões de arpejos (c. $35,36,44,48-49,60,28$ ), no uso das oitavas, sextas e quintas paralelas (c. 40-41, 50). Outro recurso bastante recorrente na obra de Salleiro, e que não havia aparecido nestas modas de viola, é a utilização dos harmônicos artificiais (c. 60-65). Notamos ainda o interessante efeito produzido nos compassos 52 a 59.

Esquema formal:

A - comp. 1 ao comp. 10;

$\mathbf{A}^{\prime}$ - comp. 11 ao comp. 68;

A - comp. 69 ao comp. 82. 

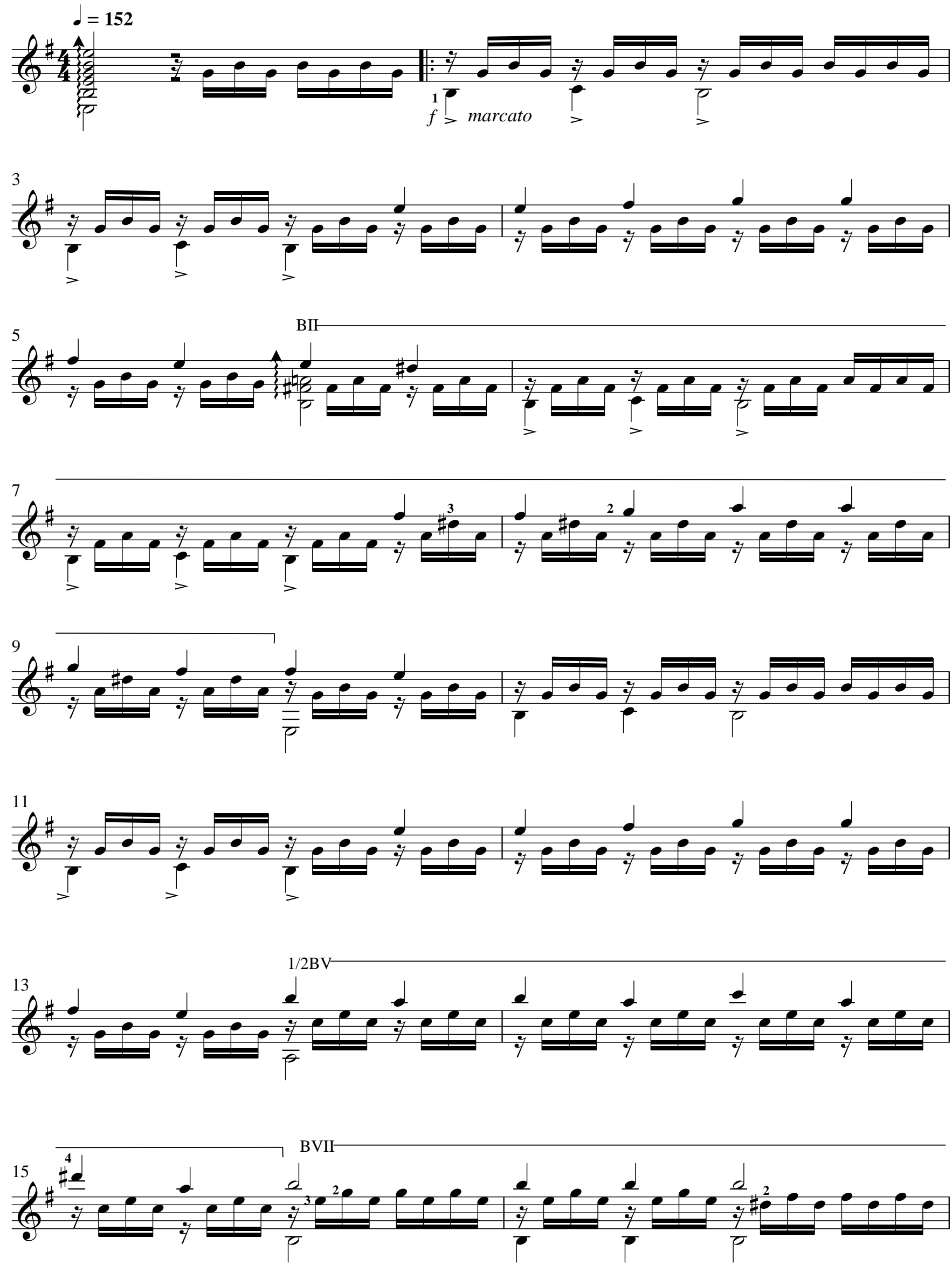

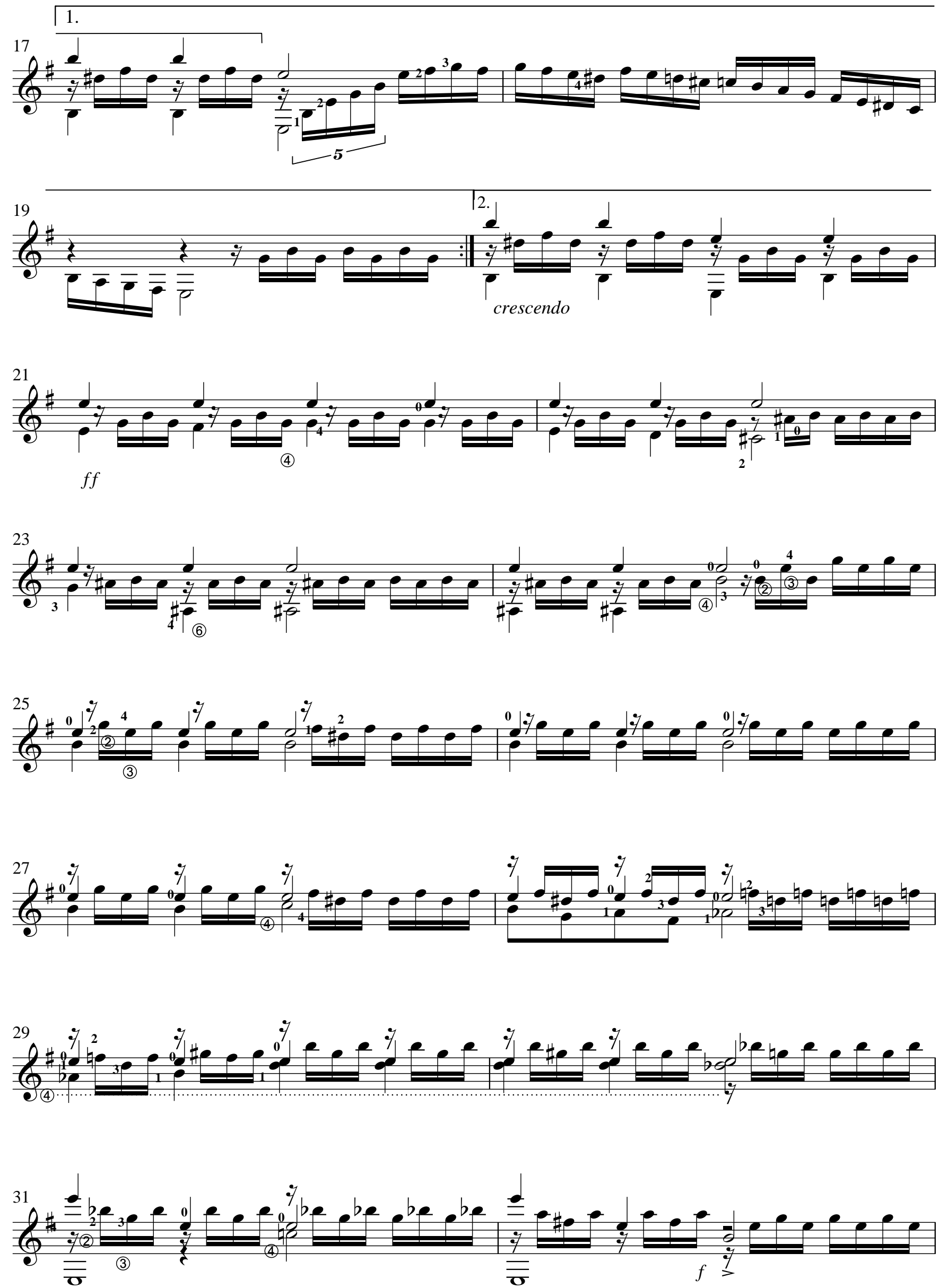

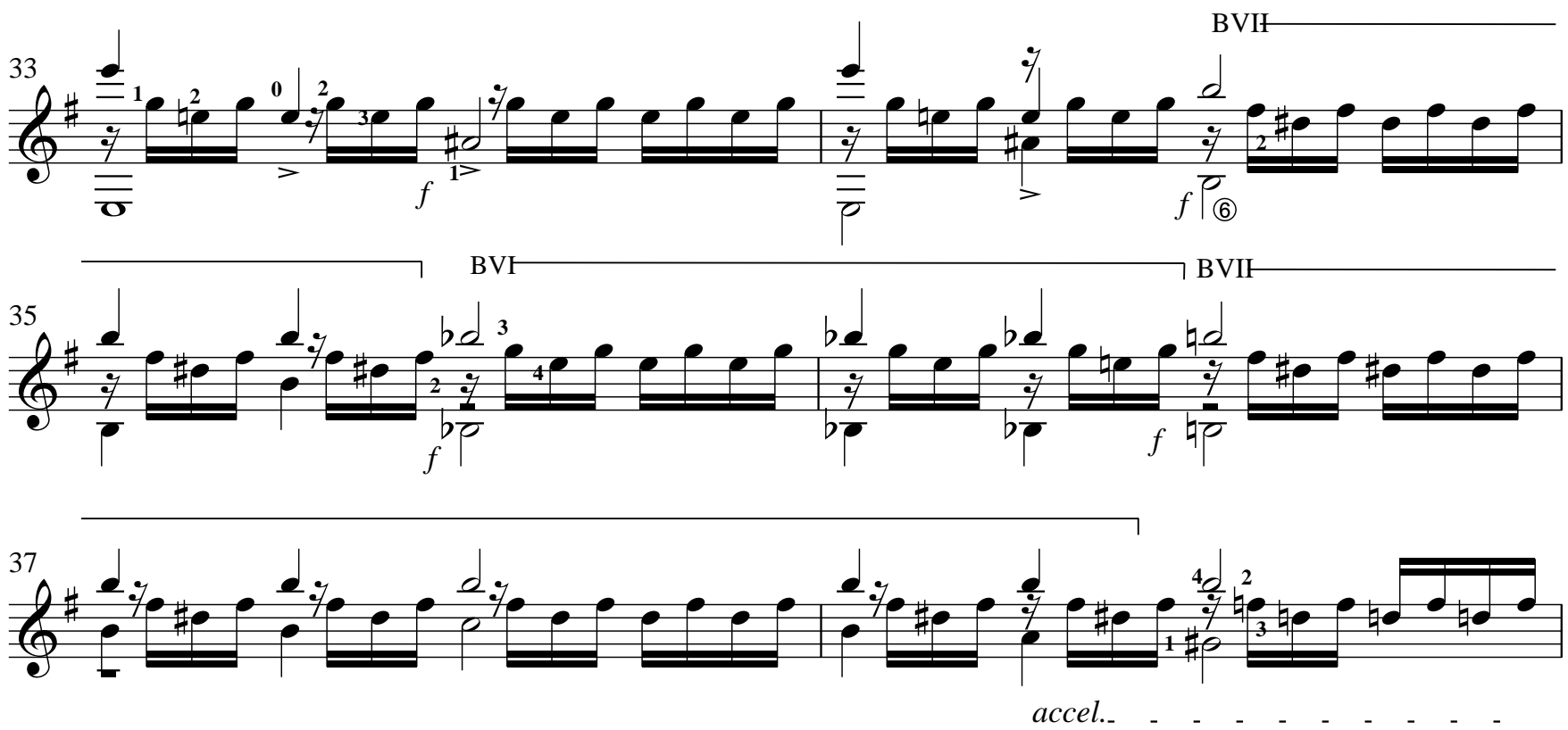

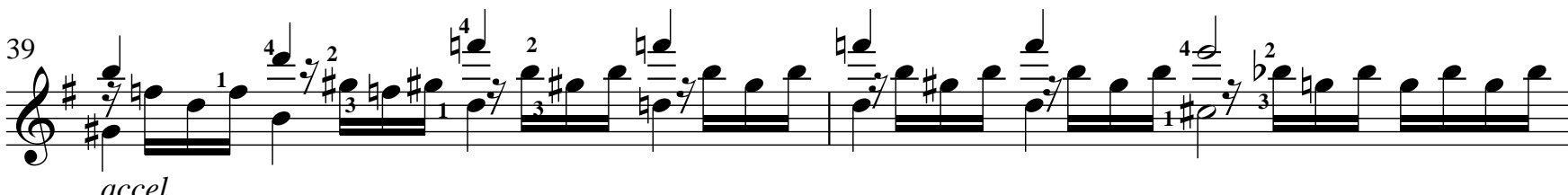

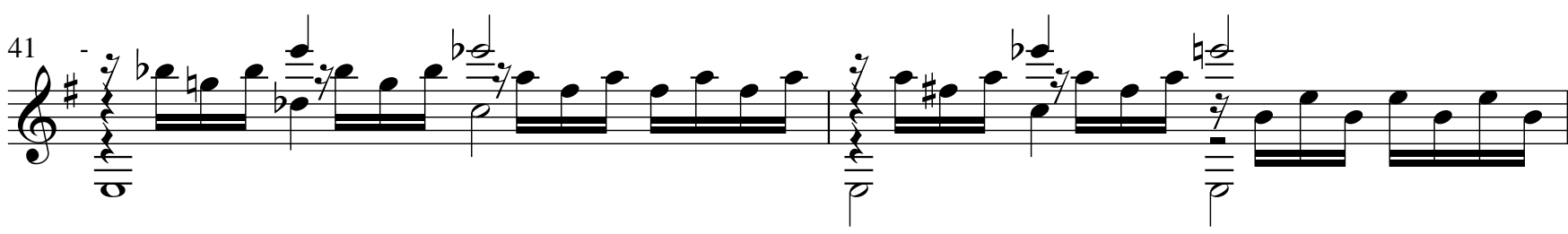

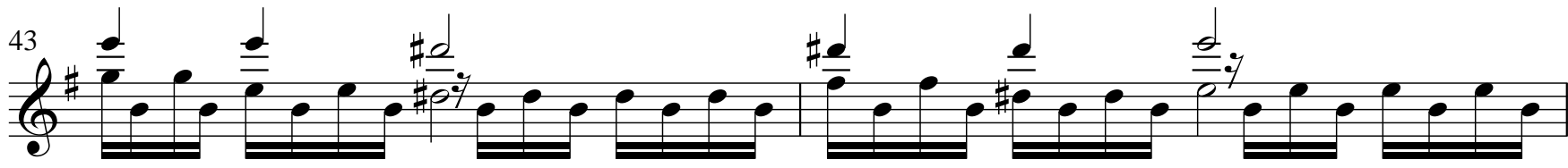

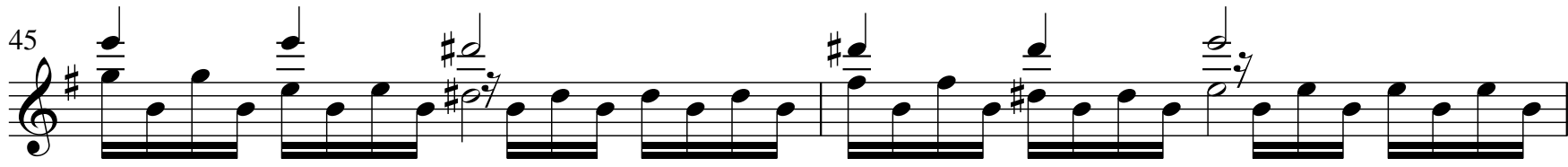

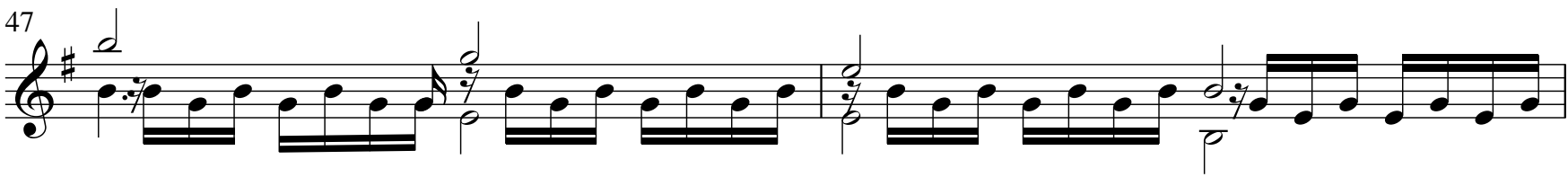

(4)

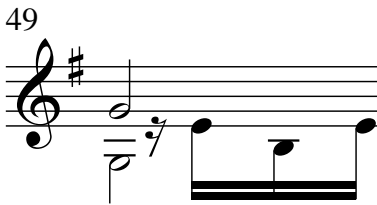

Partitura confeccionada para a dissertação de mestrado: Othon Salleiro: Um Barrios brasileiro? 

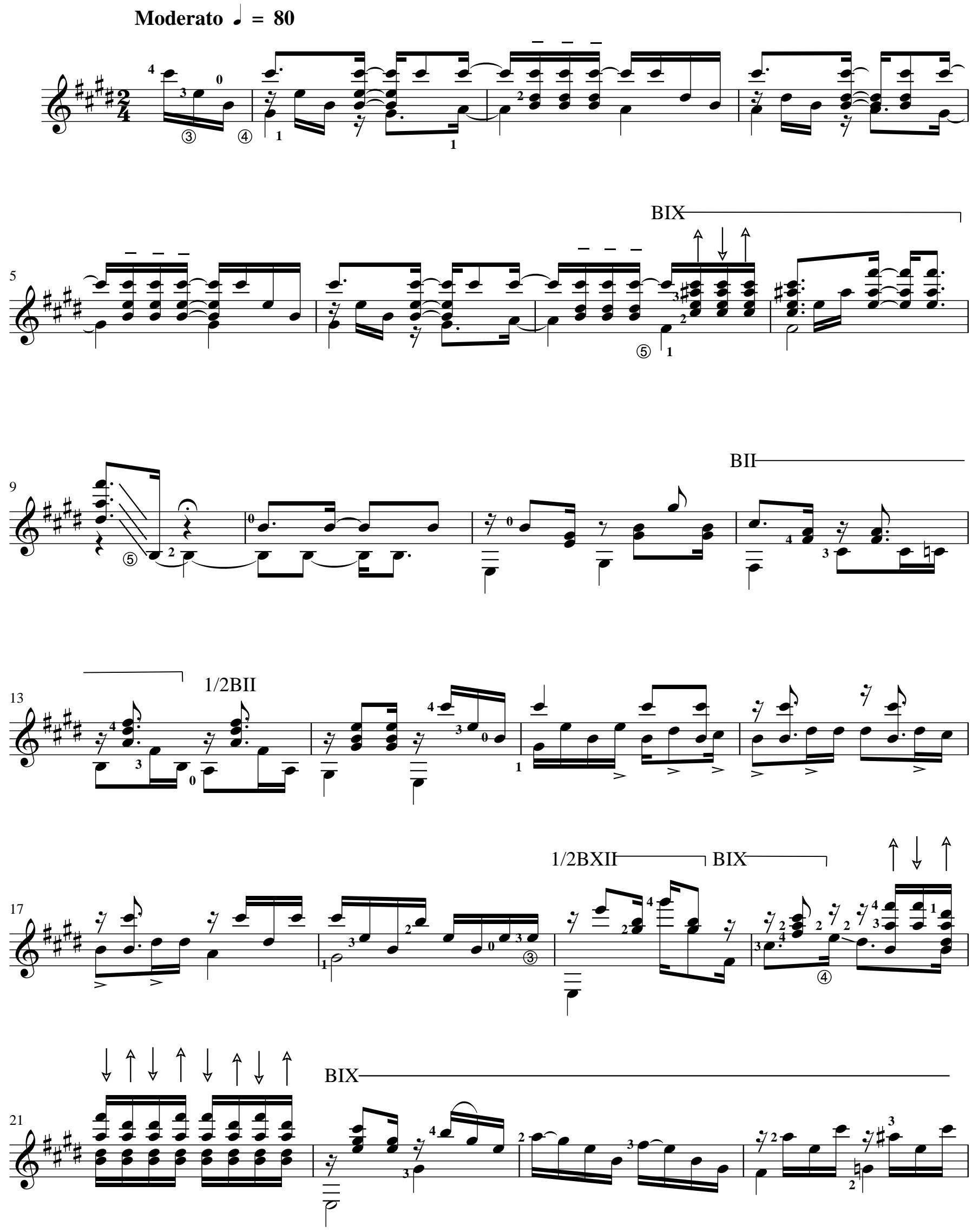


\section{BVIr}
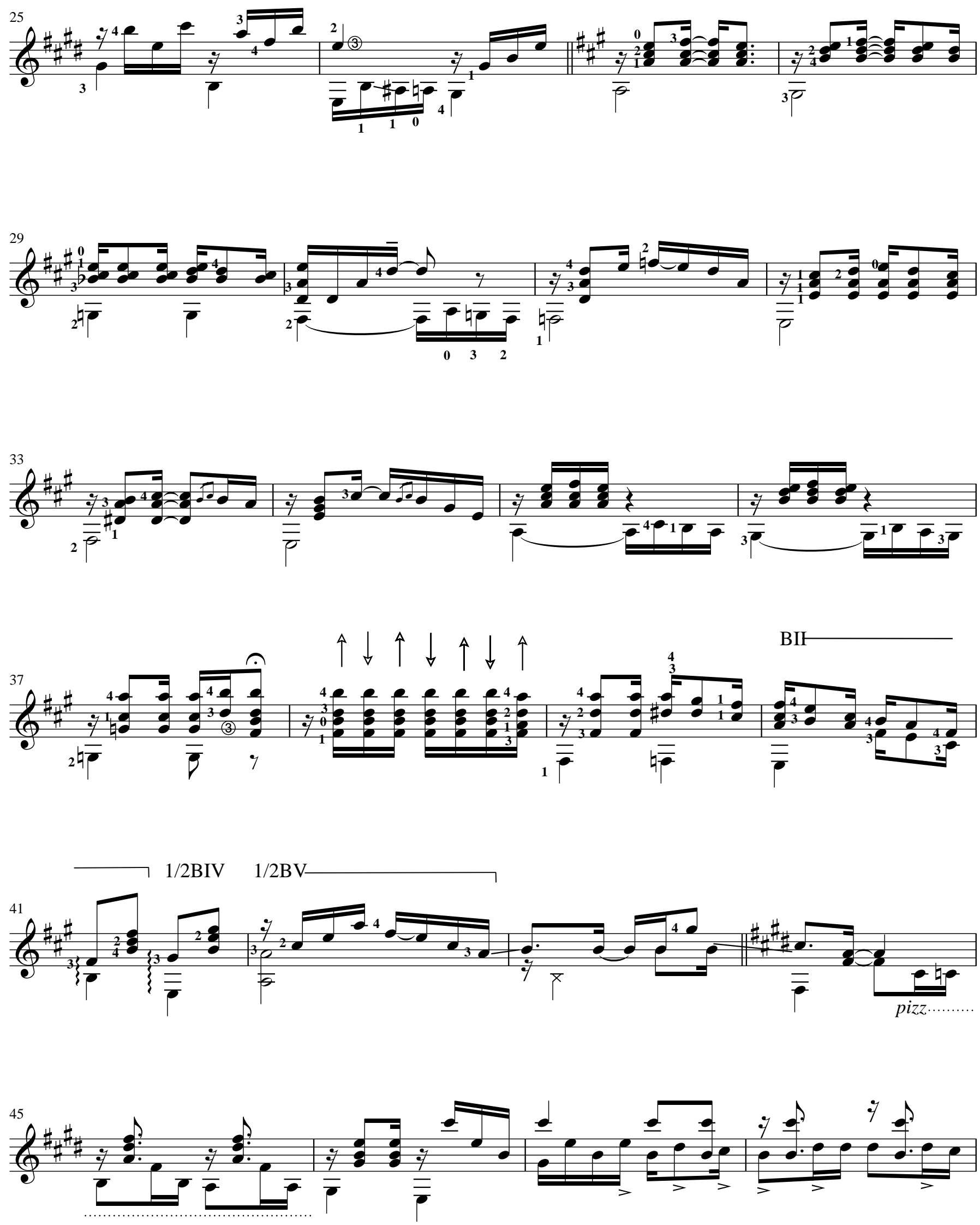


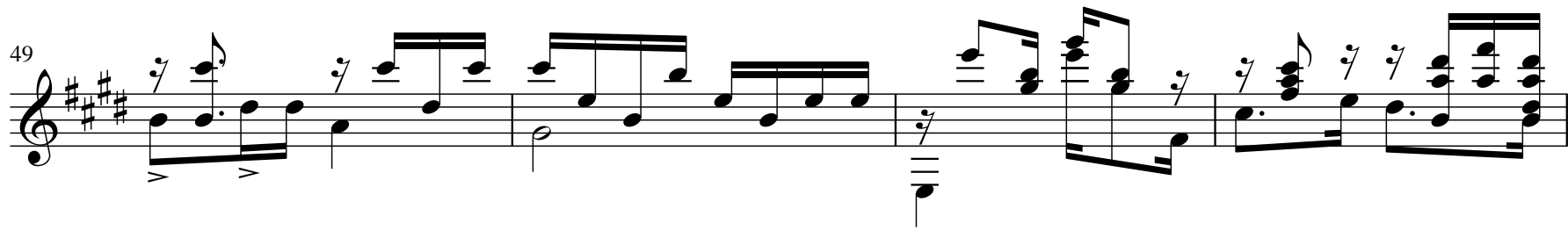

BIX

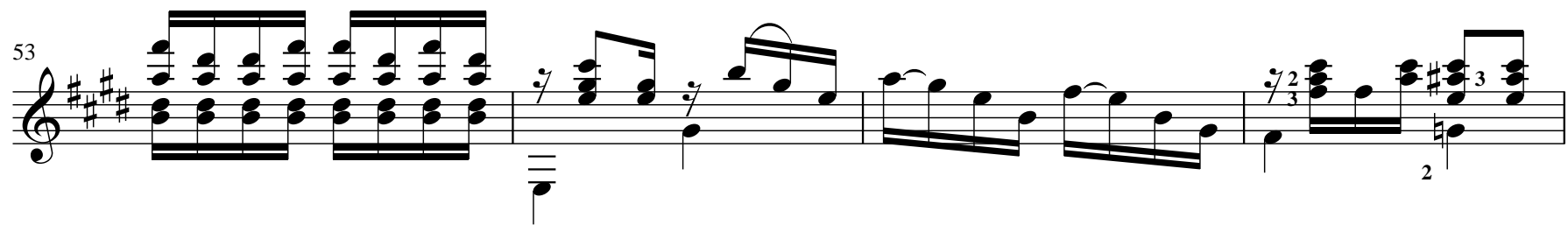

BVIץ

BIX

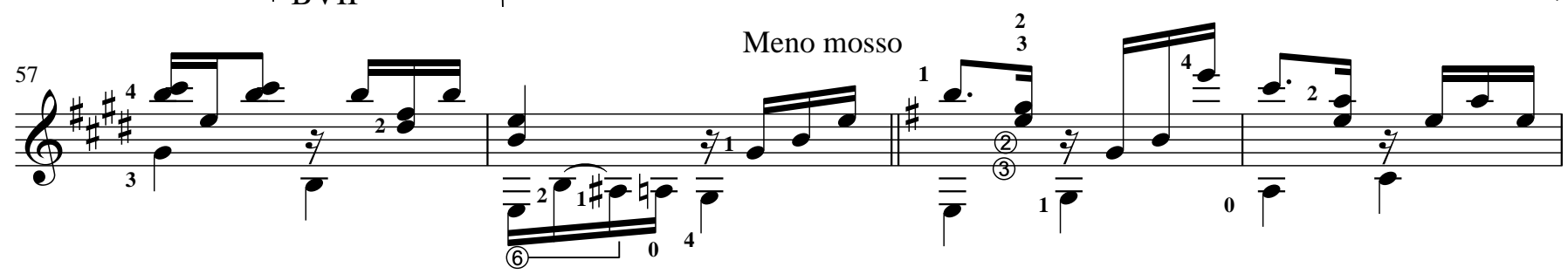

BVII
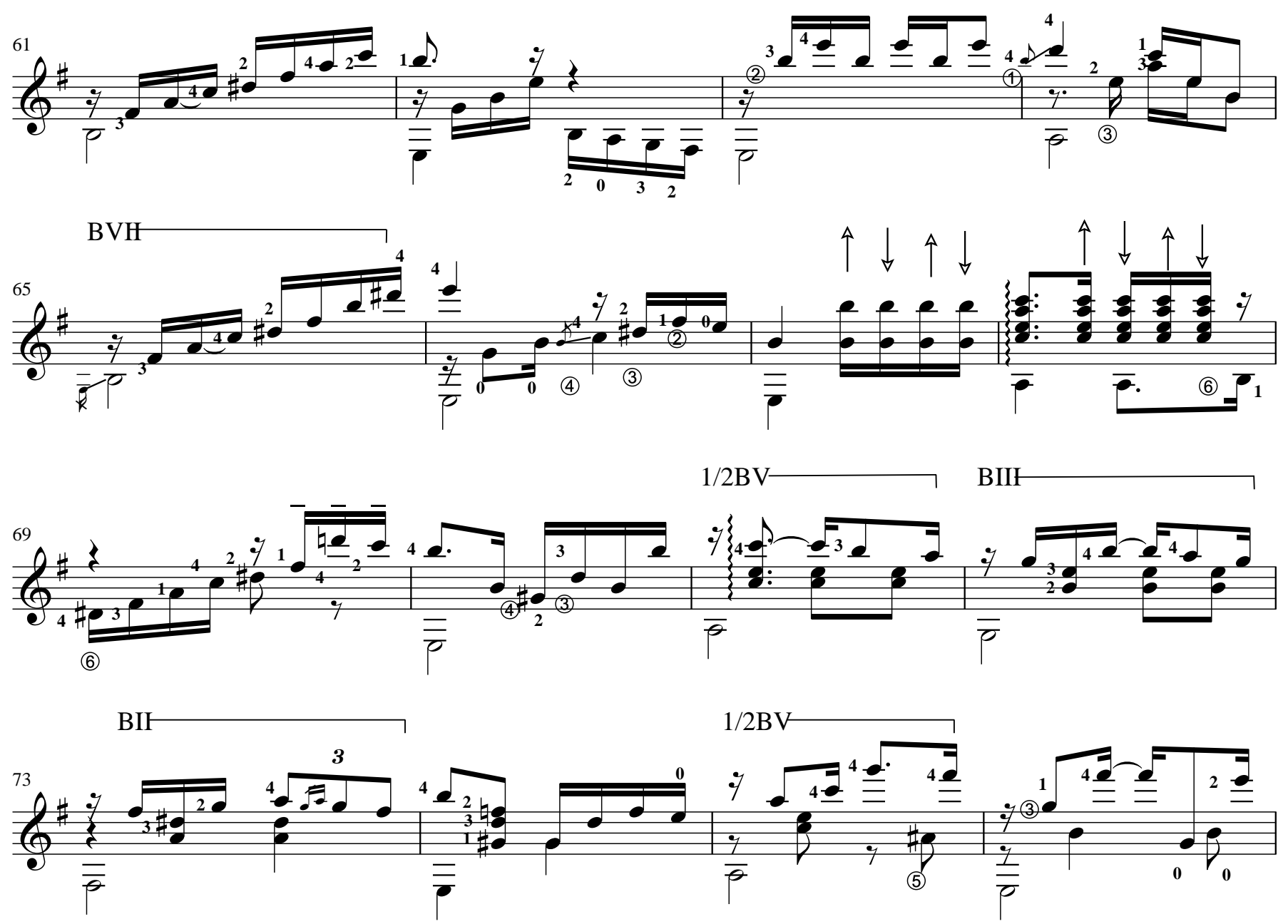
TAMBORA
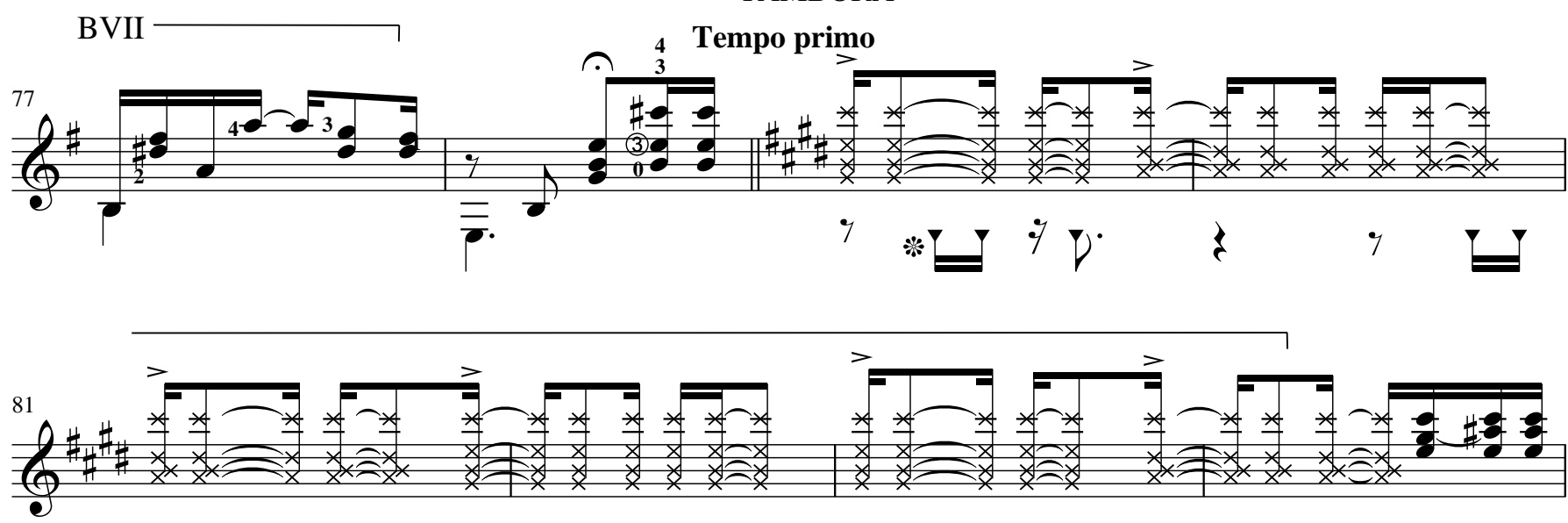

y
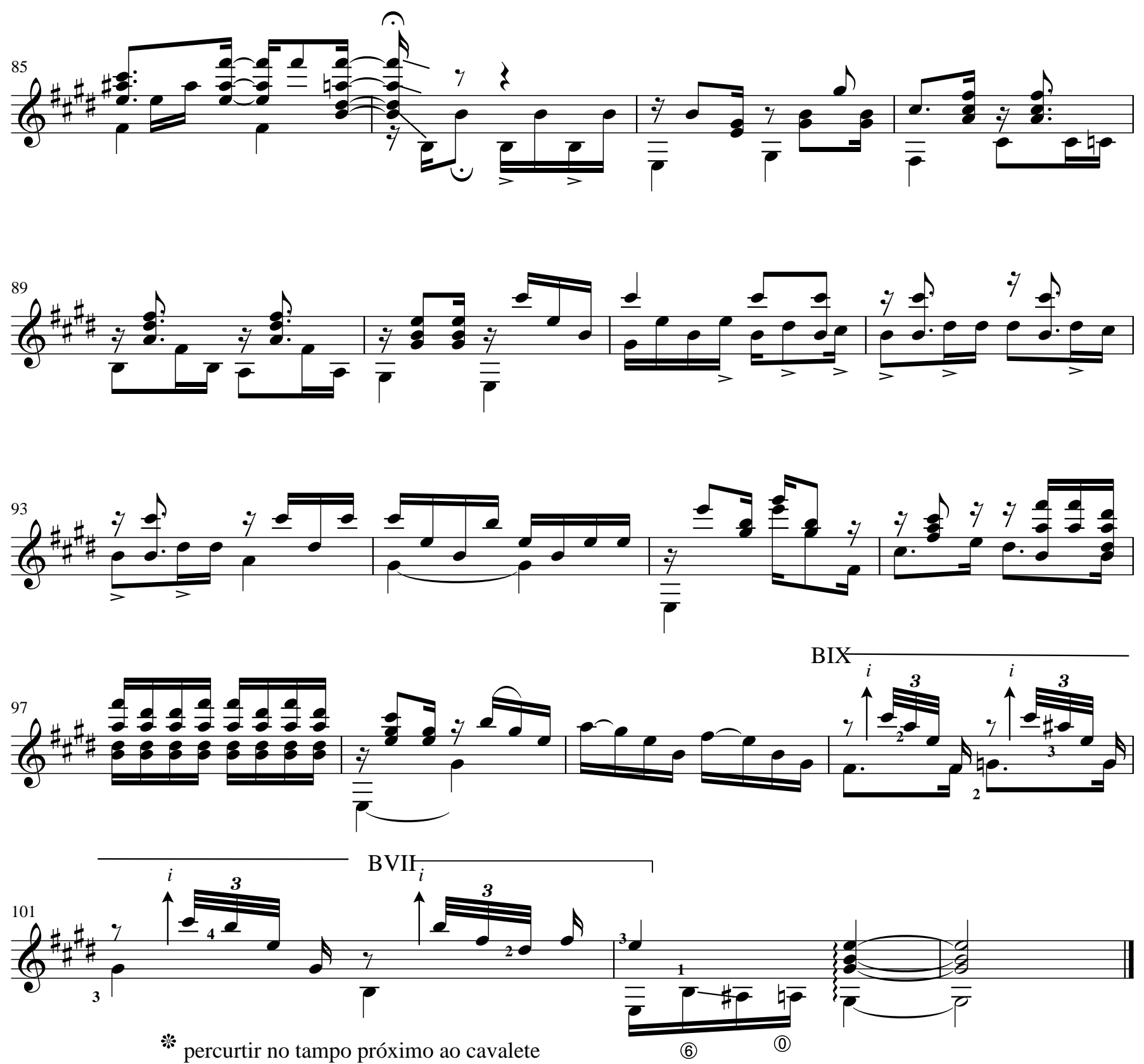

Partitura confeccionada para a dissertação de mestrado: Othon Salleiro: Um Barrios brasileiro? 
Berceuse

183

Extraída e digitada

Othon Salleiro

a partír da gravação

de Nicanor Teixeira

(6) to D. Allegro d $=144$
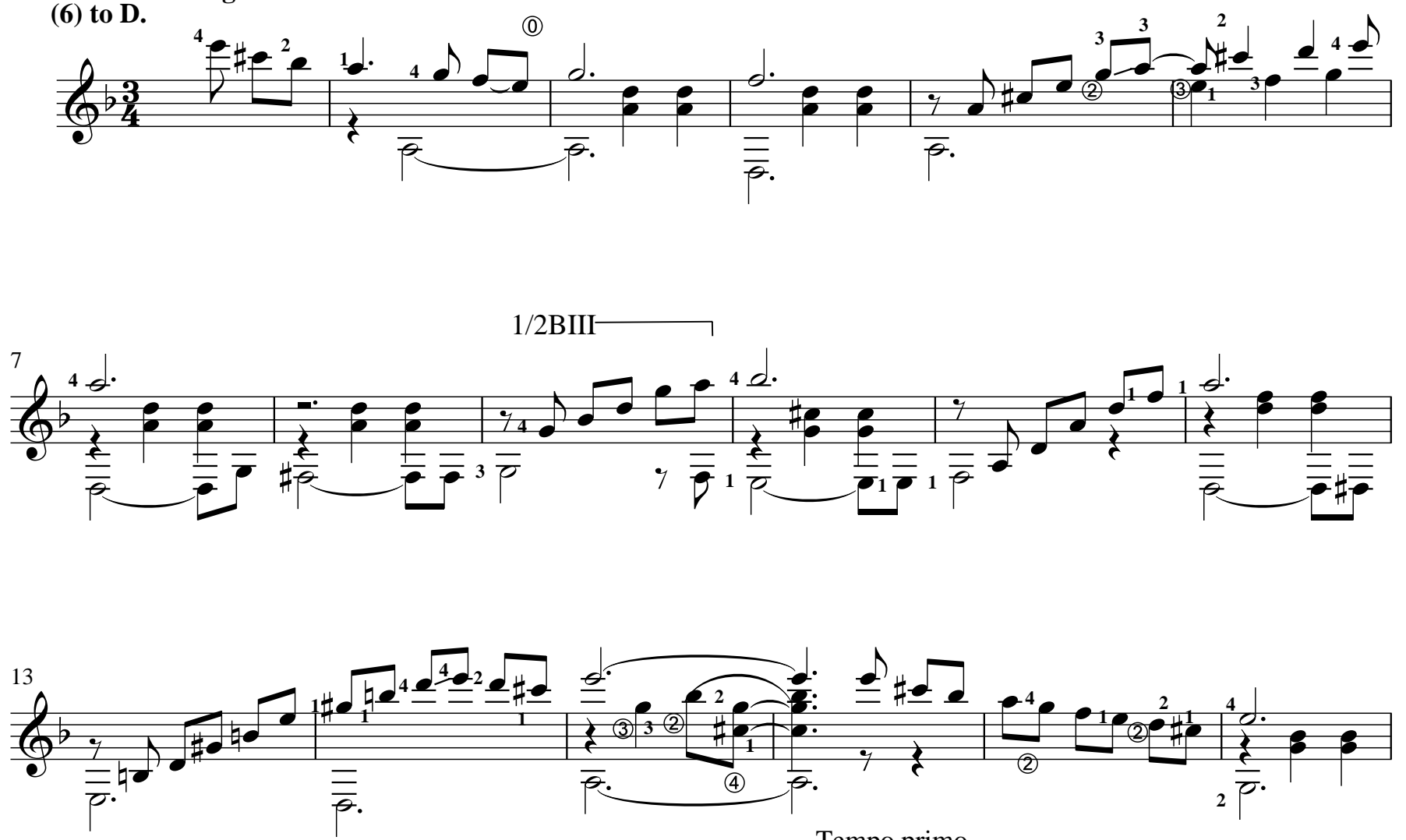

rit._ _ _ _ _ Tempo primo
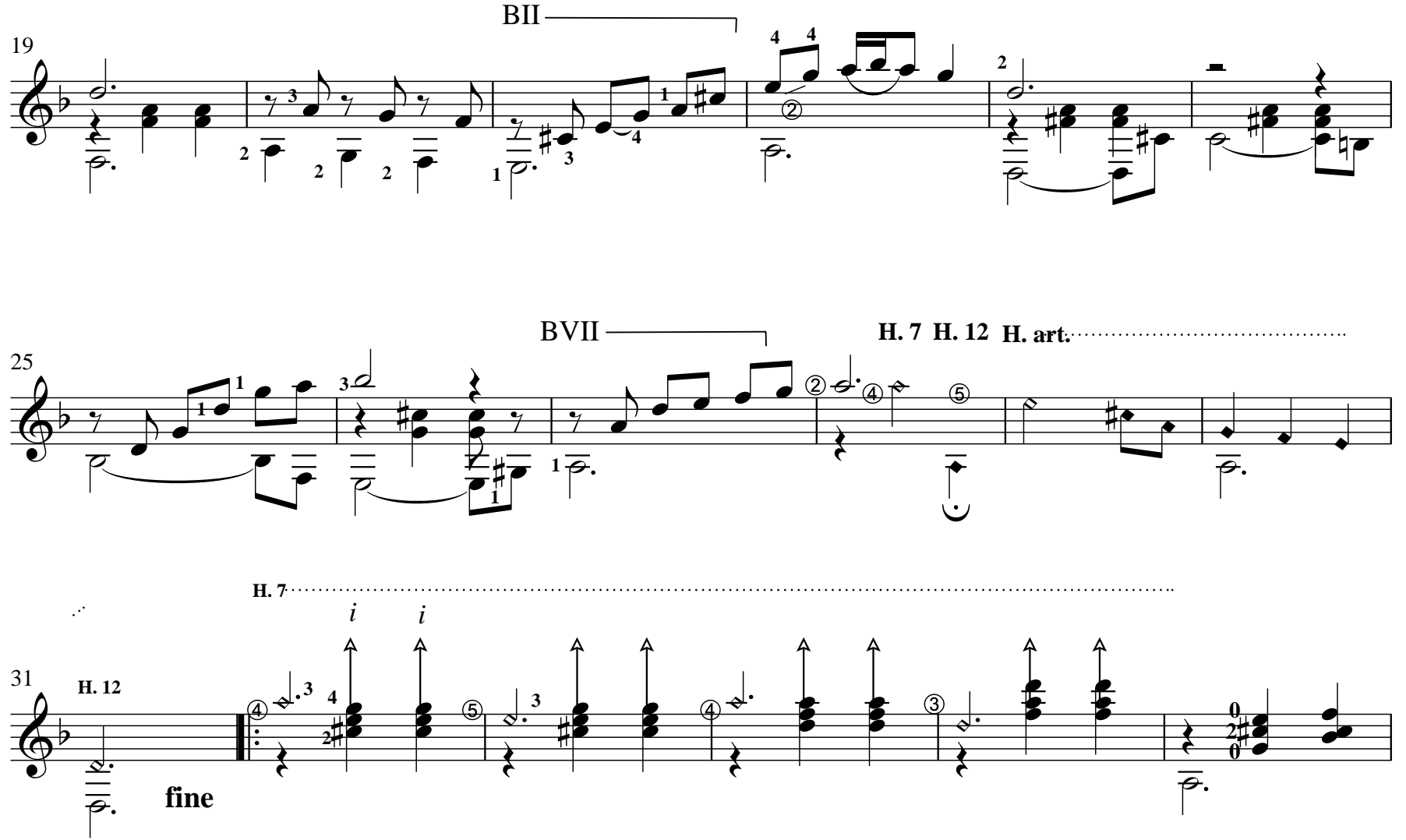

Partitura confeccionada para a dissertação de mestrado: Othon Salleiro: Um Barrios brasileiro?

Flavia Prando - ECA/USP - 2008 
Berceuse contínuação (1)

184

2

Othon Salleiro

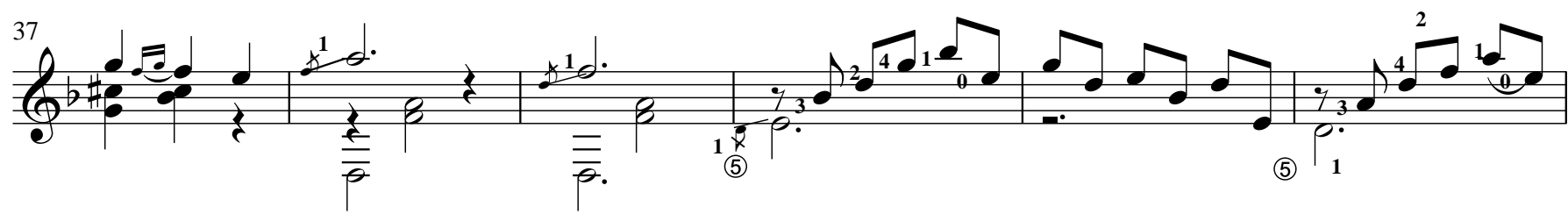

1.
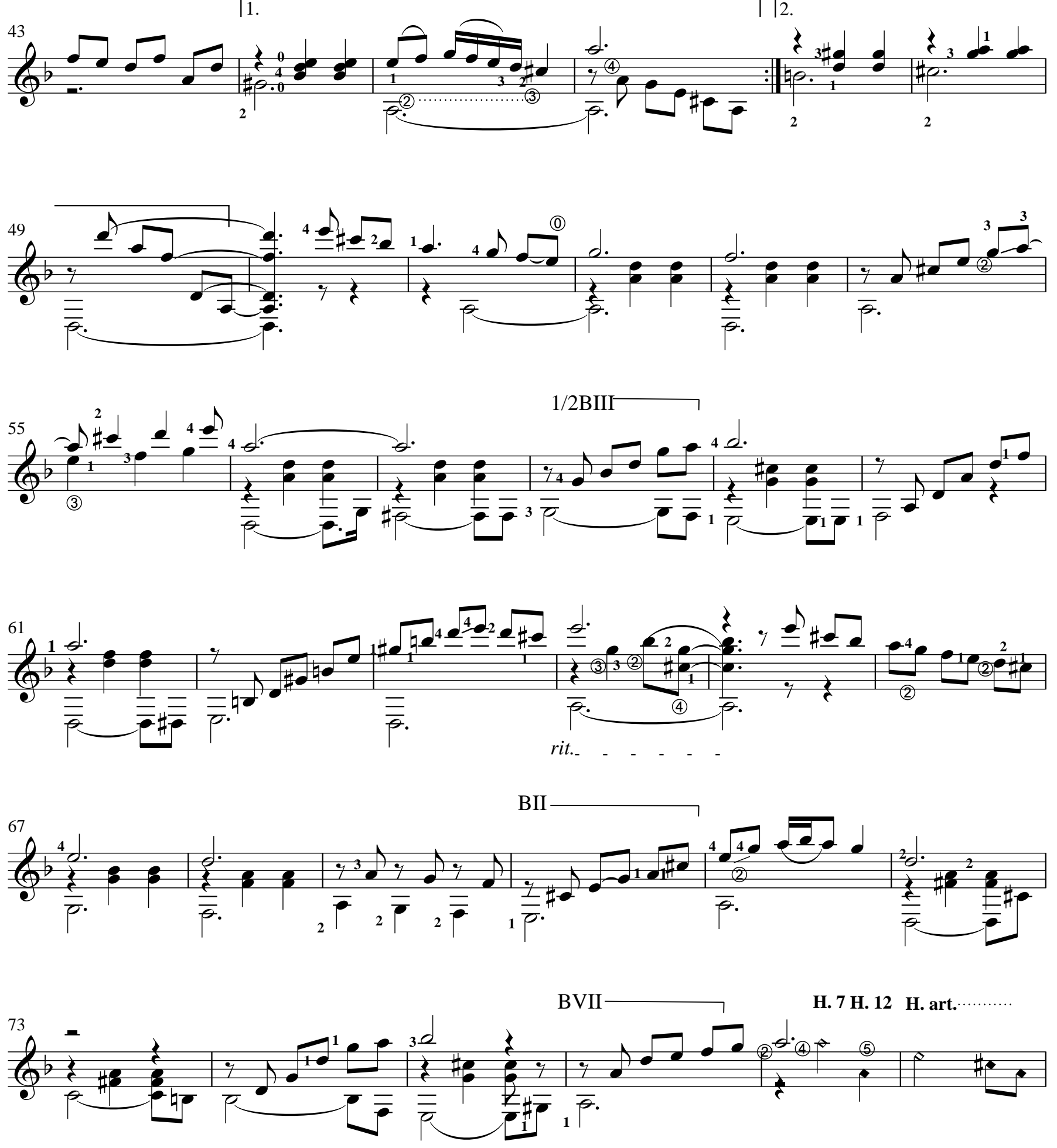

Partitura confeccionada para a dissertação de mestrado: Othon Salleiro: Um Barrios brasileiro?

Flavia Prando - ECA/USP - 2008 

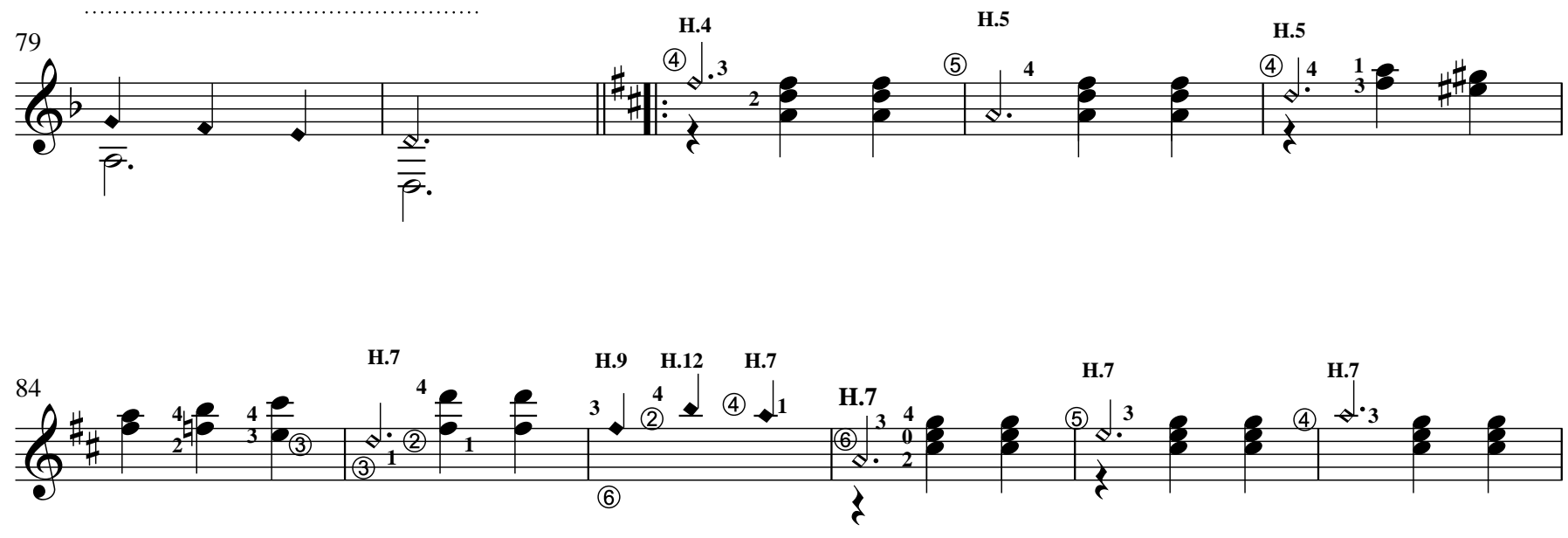

H.7

H.4

1/2BVII
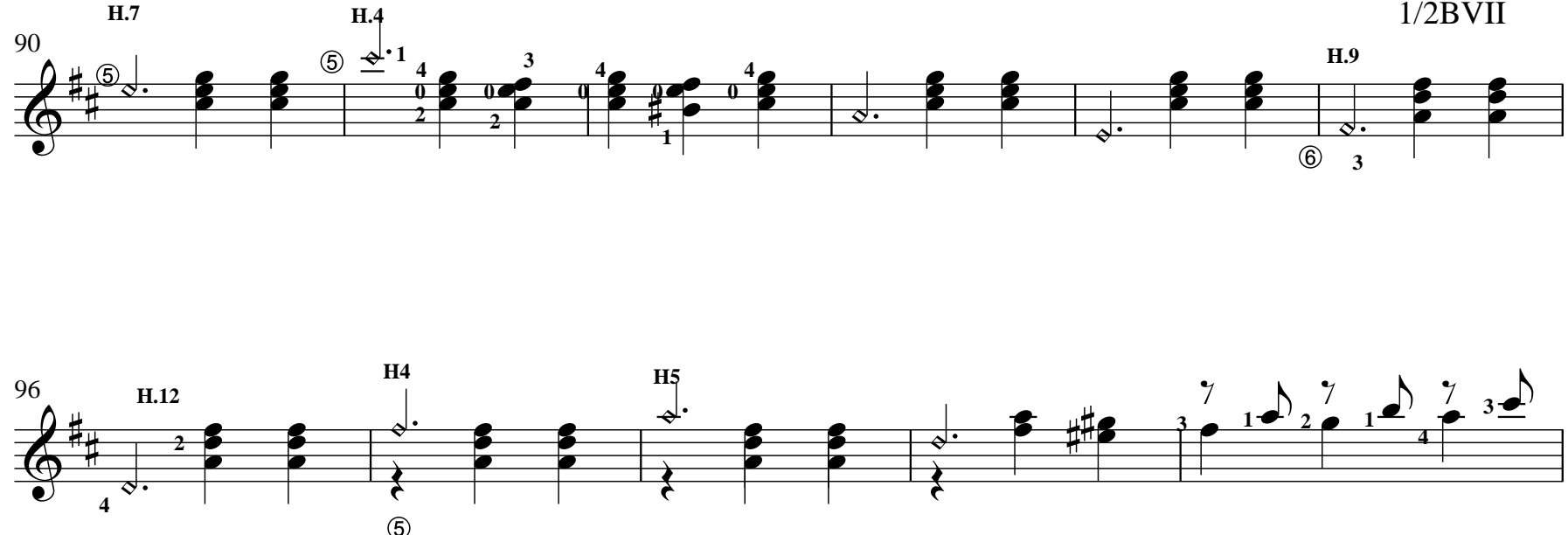

rit._ - $\quad$ a tempo

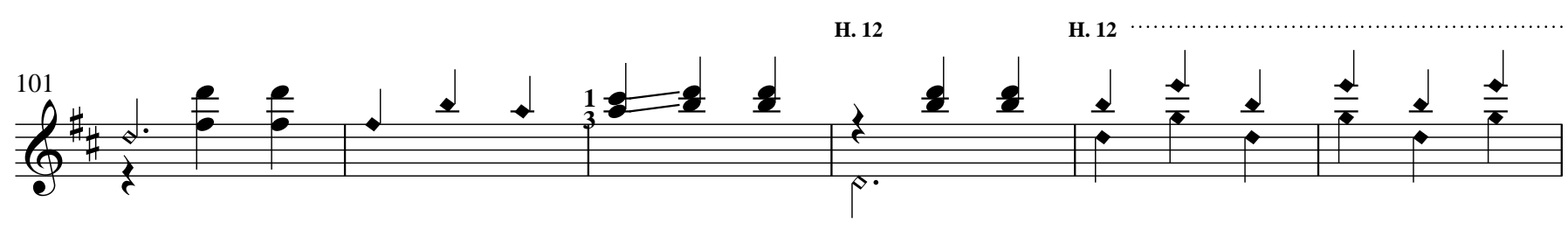

H. 7

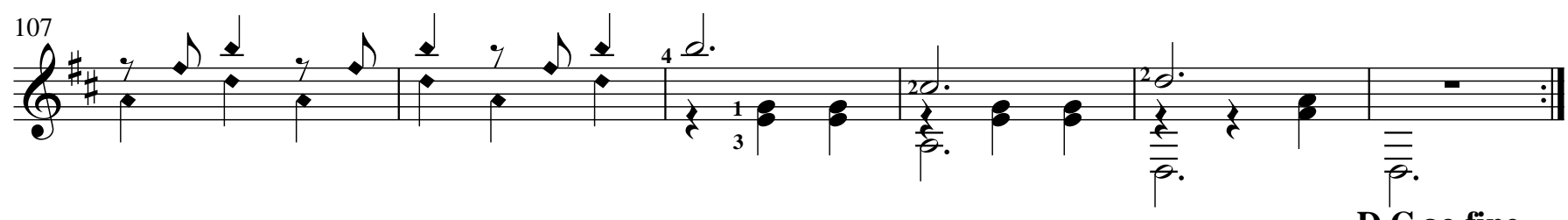

Partitura confeccionada para a dissertação de mestrado: Othon Salleiro: Um Barrios brasileiro?

Flavia Prando - ECA/USP - 2008 
Anotado

por Nicanor Teixeira

(1980)
Cavaquinho em Serenata

(Maxixe)

a João Pernambuco
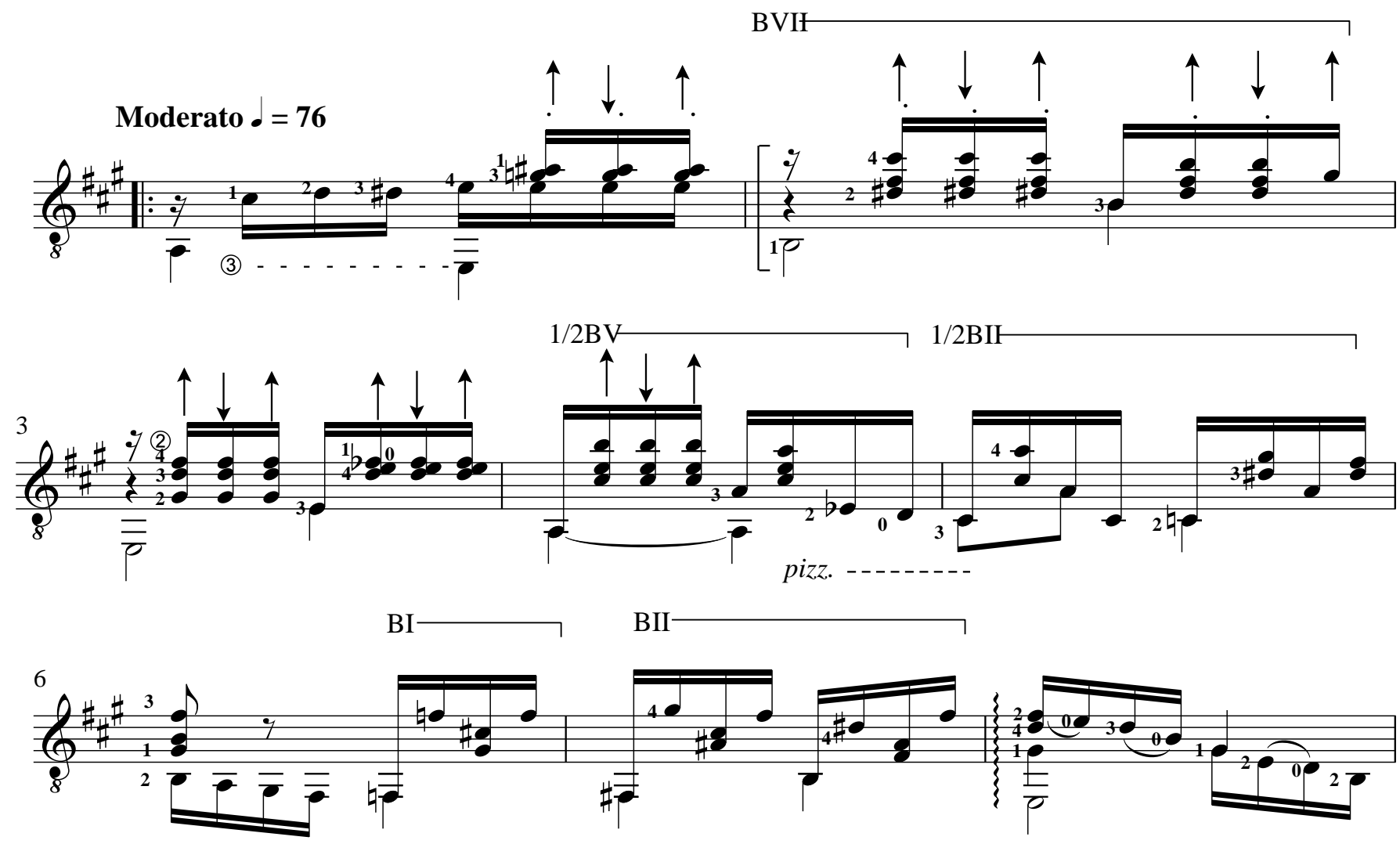
pizz.--.---.-

A tempo

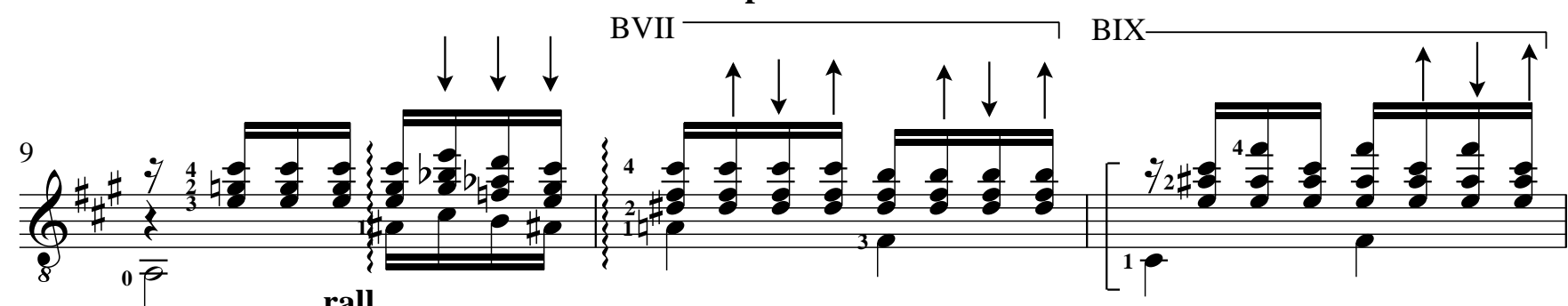

rall.
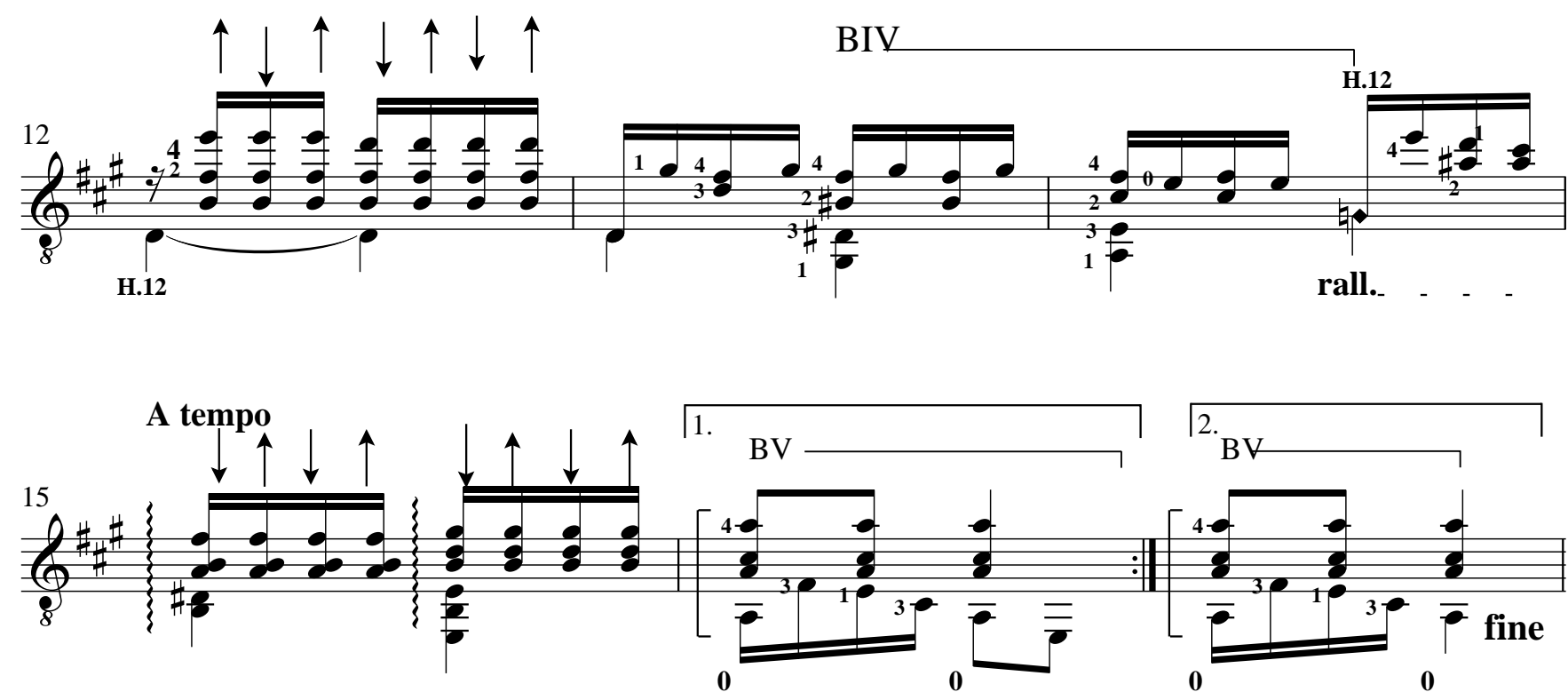

Partitura confeccionada para a dissertação de mestrado: Othon Salleiro: Um Barrios brasileiro?

Flavia Prando - ECA/USP - 2008 

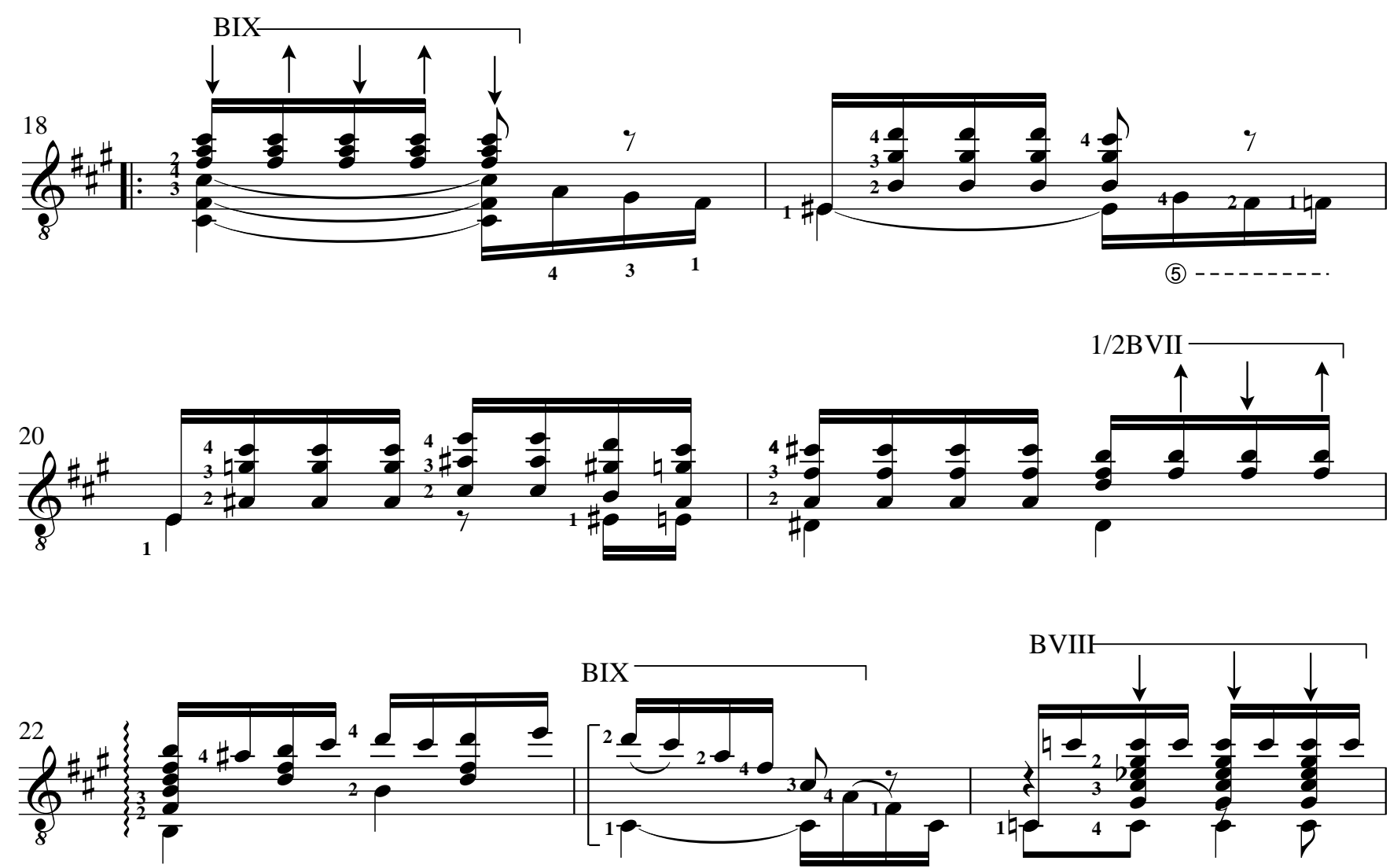

BIX

BII

BI
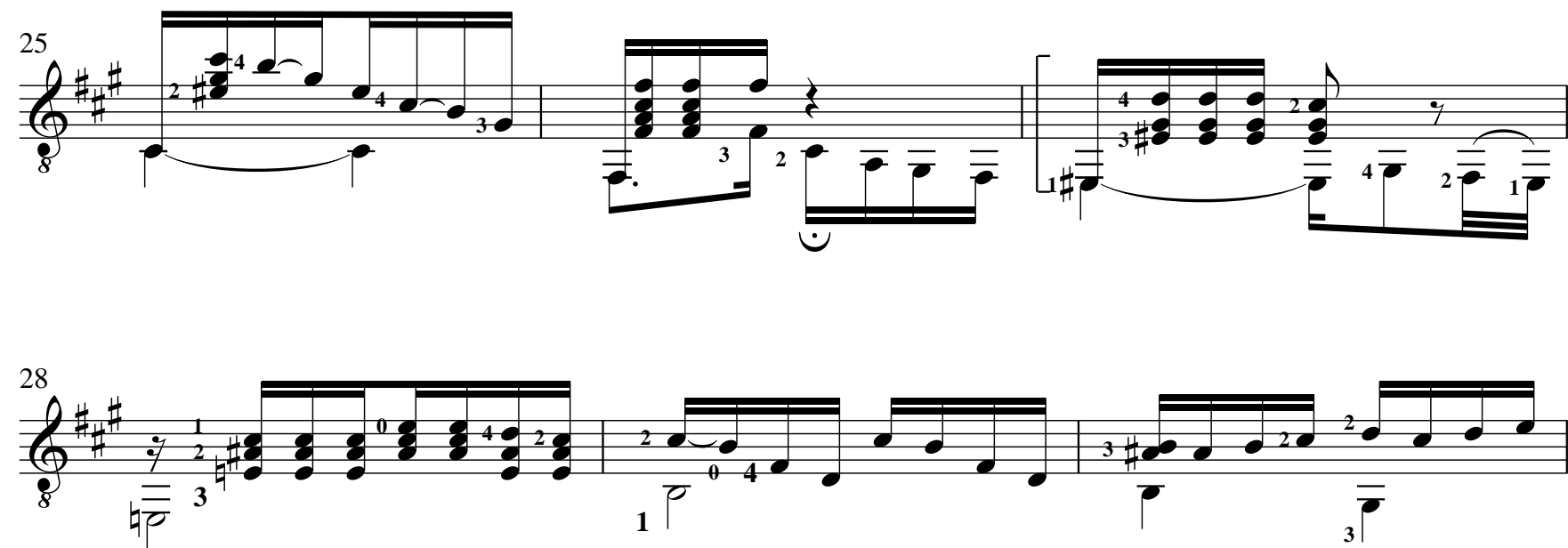

BIX

BI

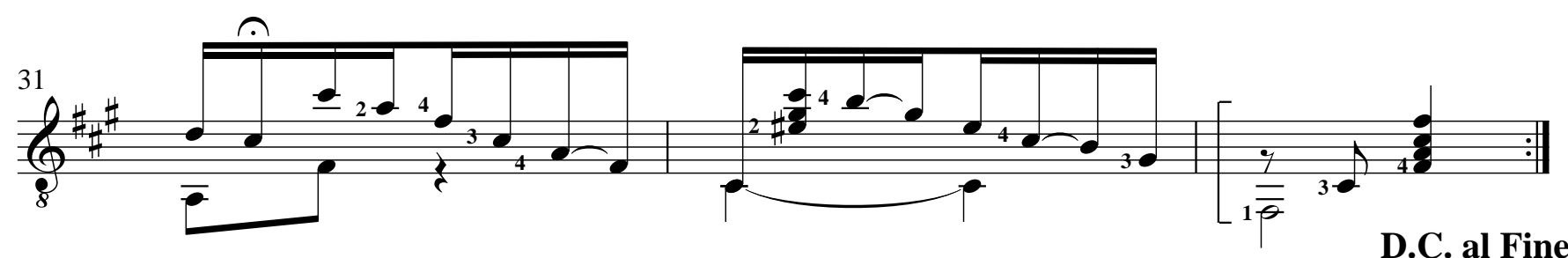

Partitura confeccionada para a dissertação de mestrado: Othon Salleiro: Um Barrios brasileiro? 

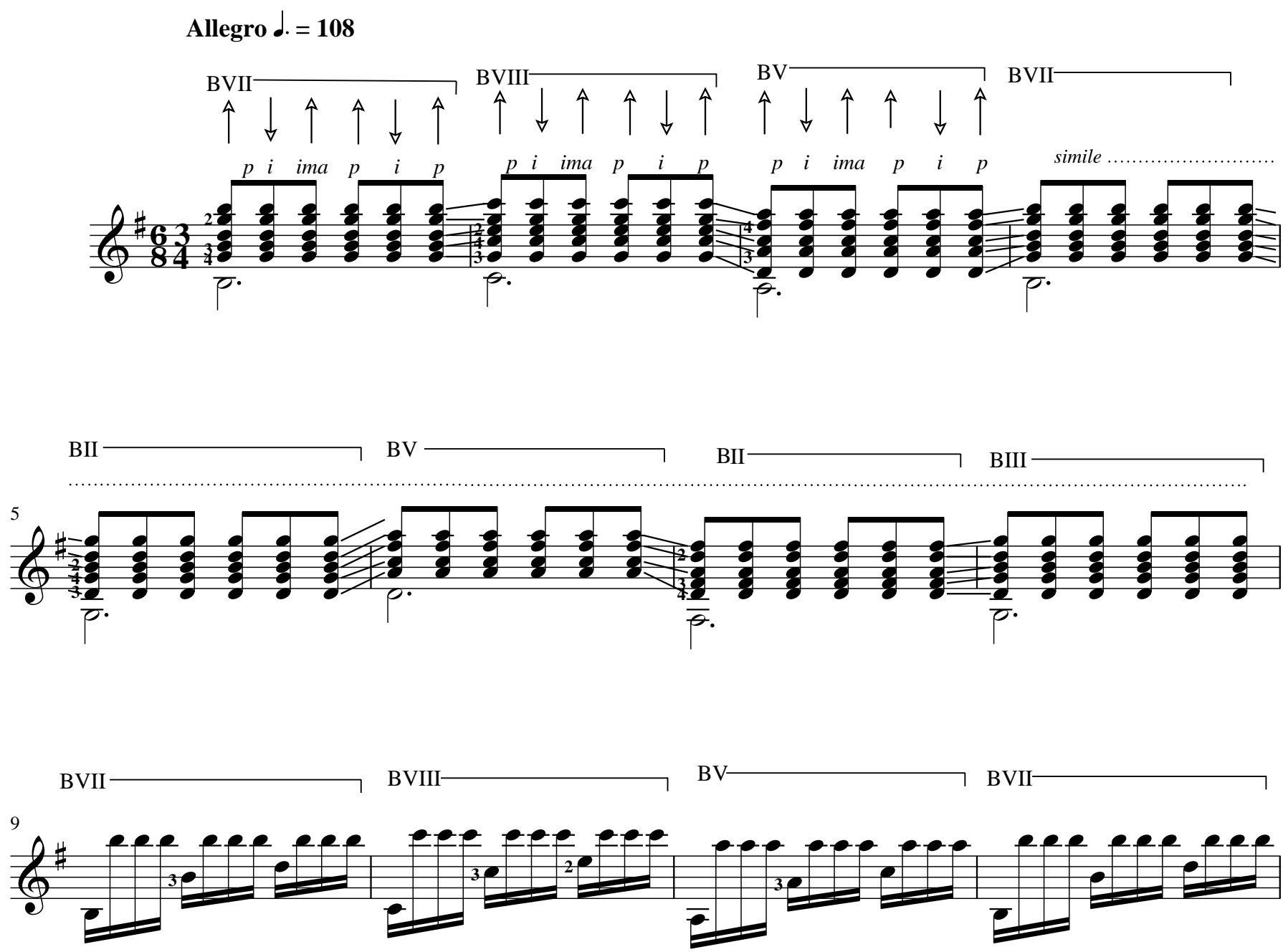

BIII

$\mathrm{BV}$

BII

BIII

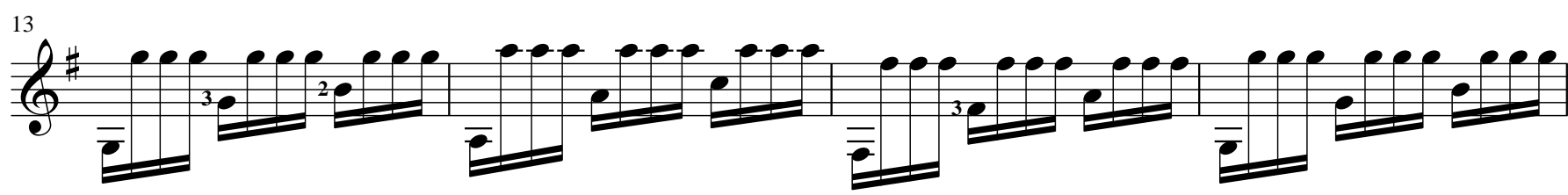

H. art:

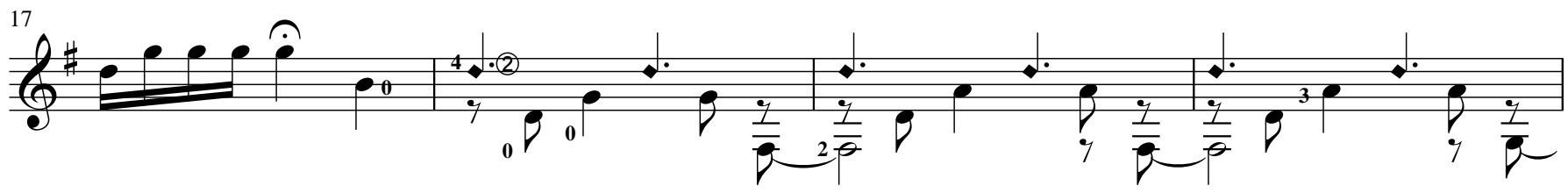


Chimarrita continuação (1)

189

2

Othon Salleiro
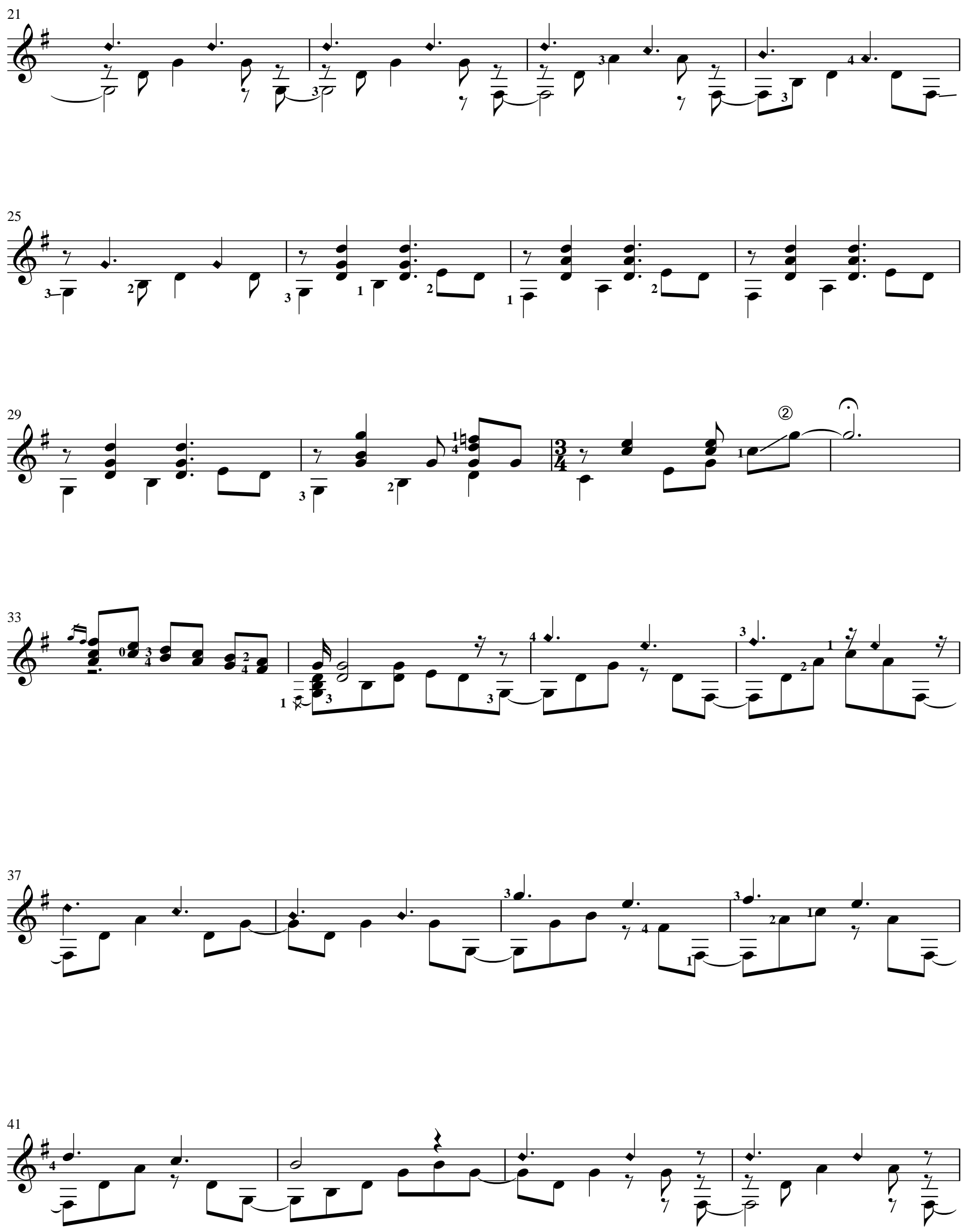

Partitura confeccionada para a dissertação de mestrado: Othon Salleiro: Um Barrios brasileiro?

Flavia Prando - ECA/USP - 2008 

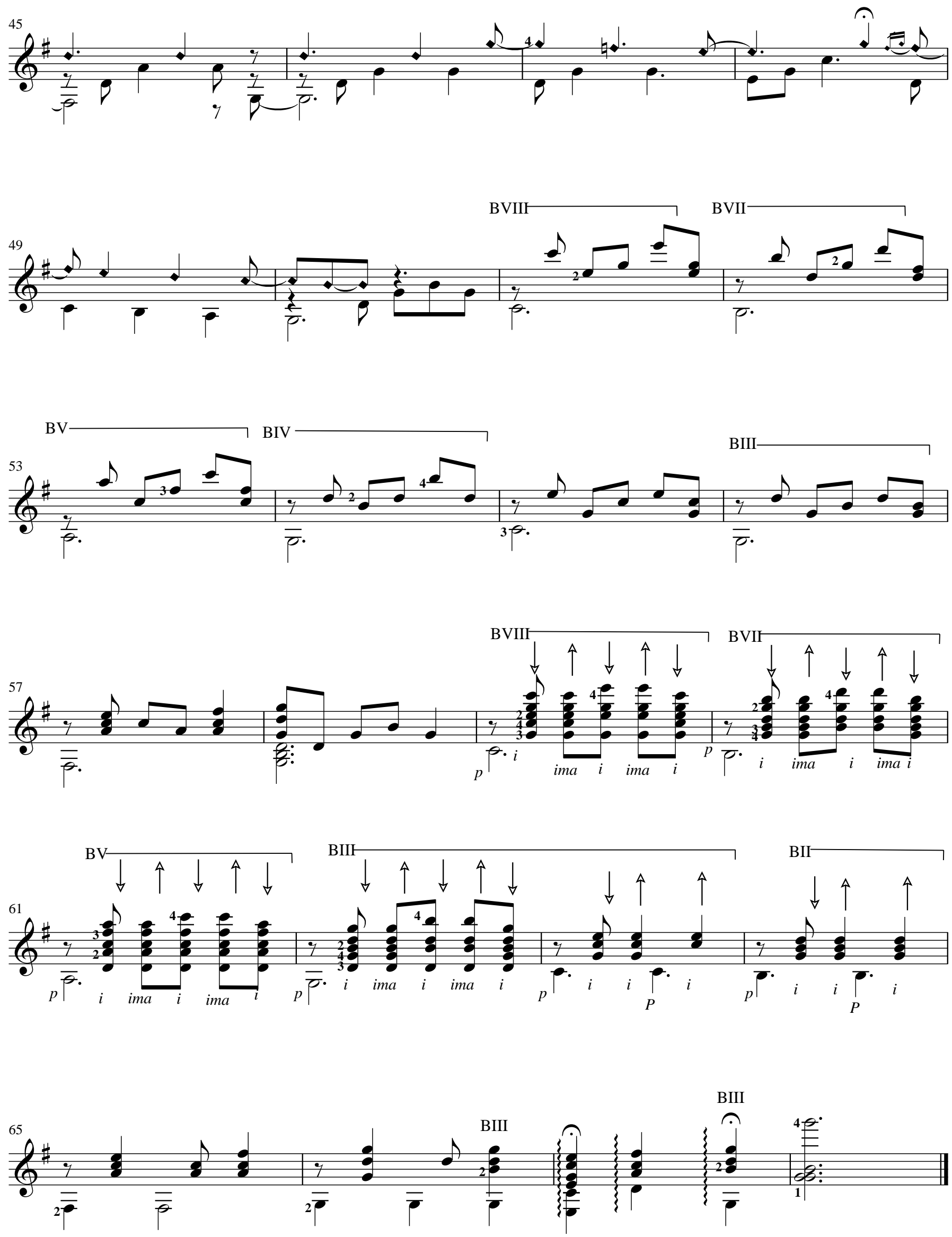
Moderato $\downarrow=82$

BV
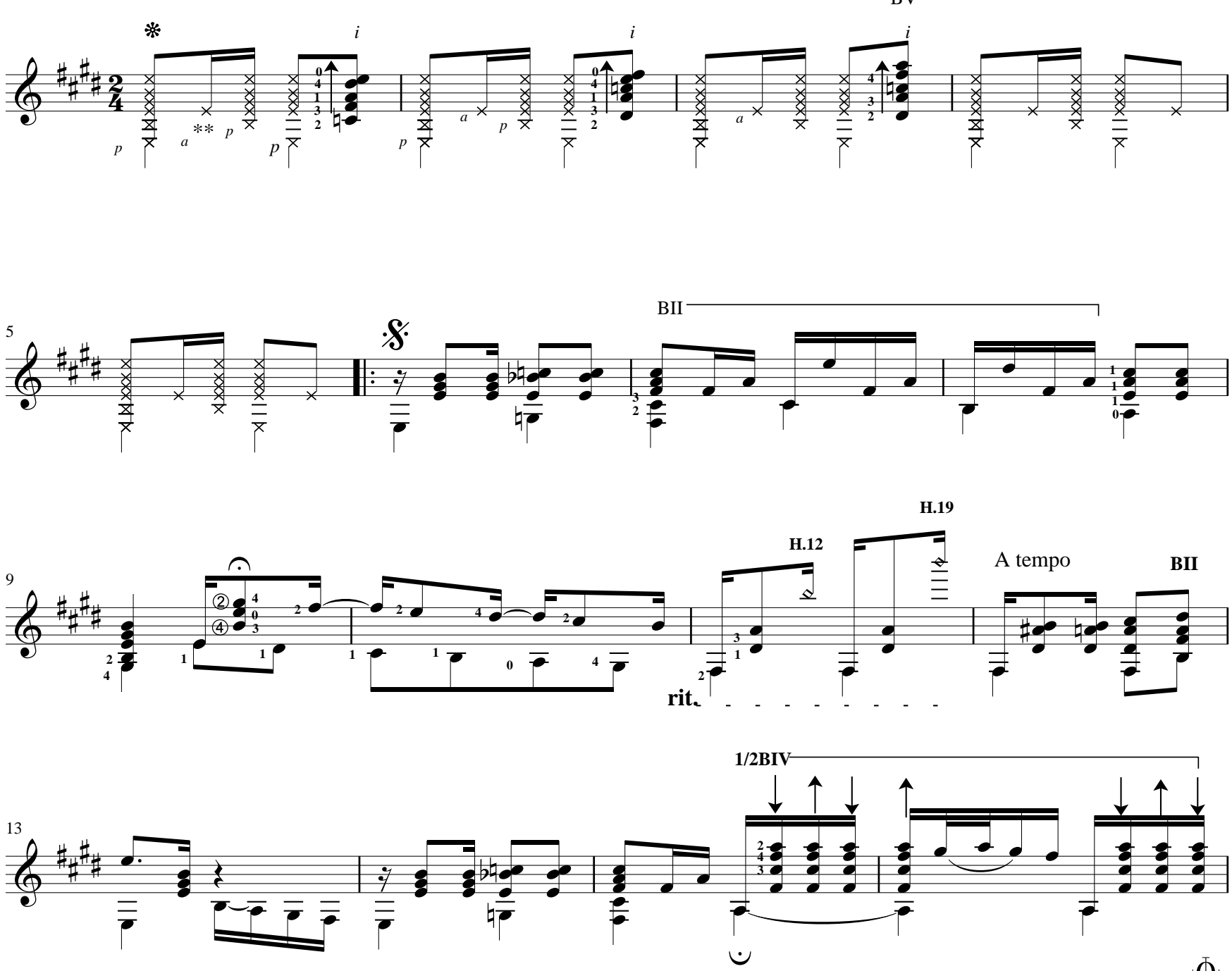

$\varphi$

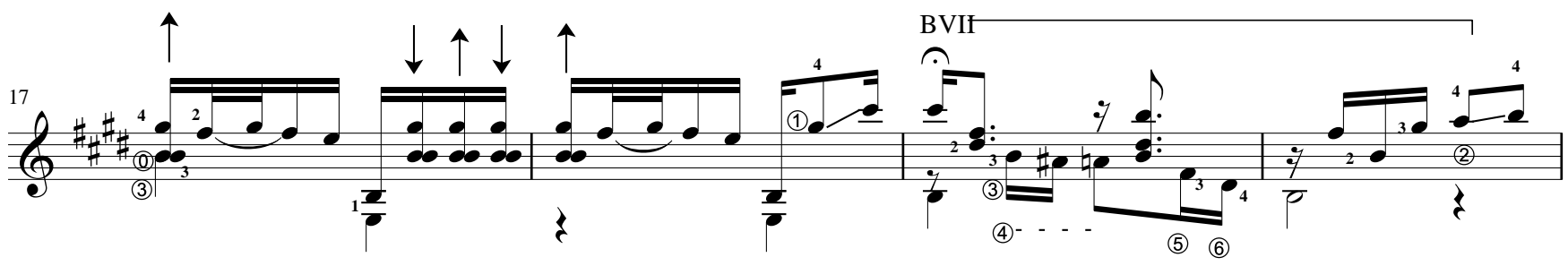

Meno mosso

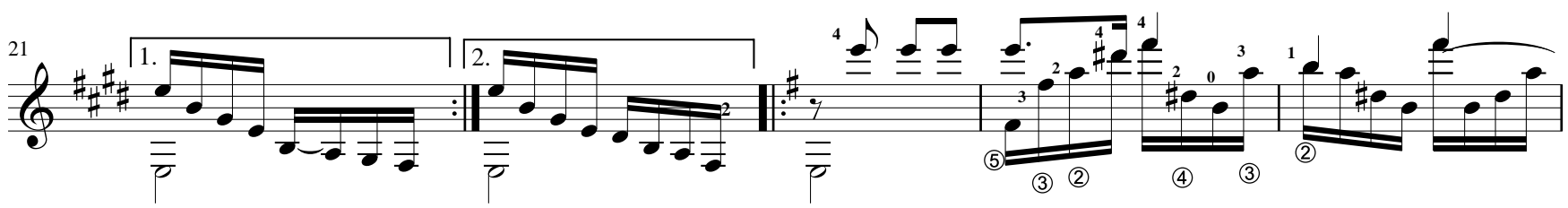

* TAMBORA - percutir com lateral do polegar (mão direita) nas cordas, próximo ao cavalete

**Percutir com anular (mão direita) no tampo, próximo ao cavalete 

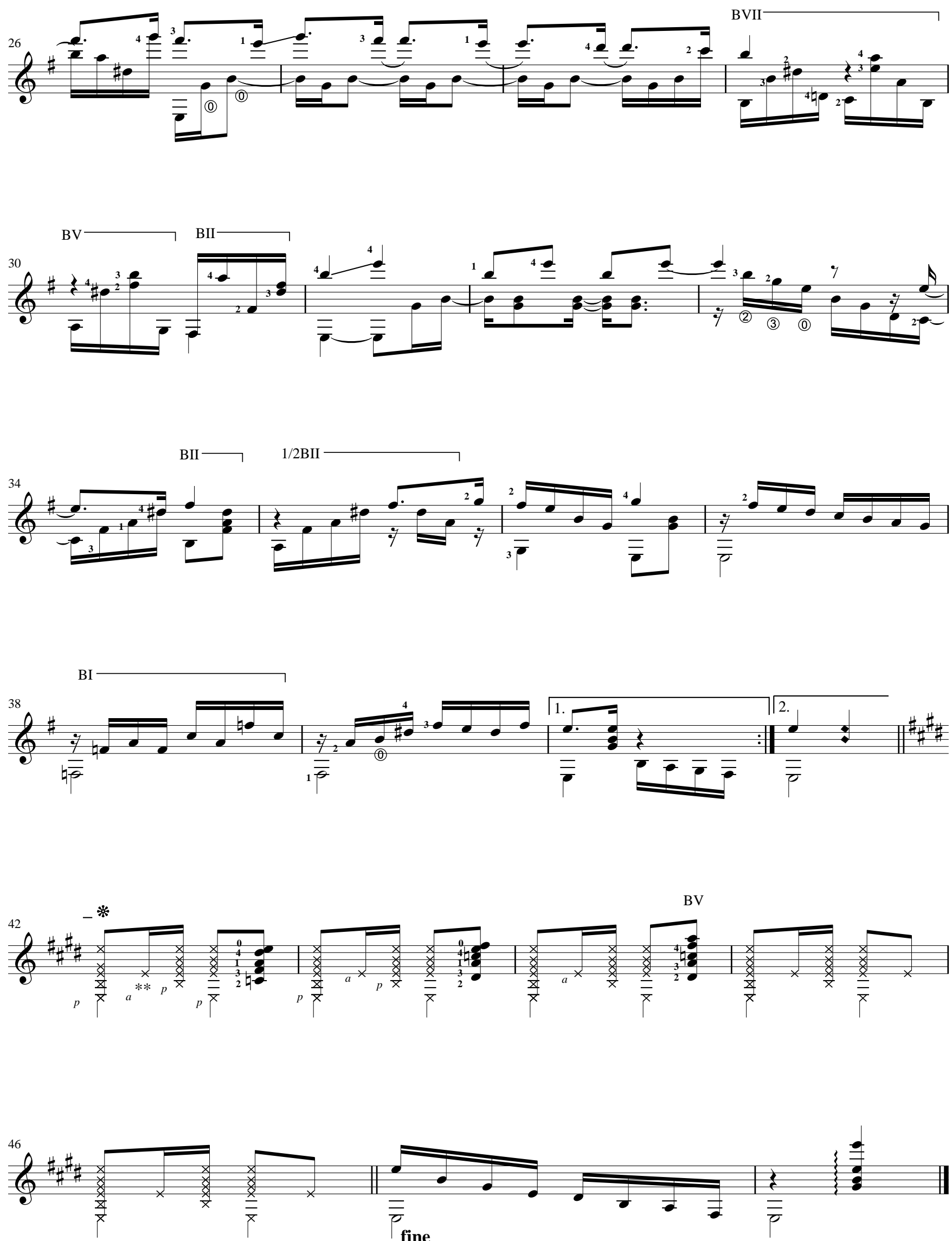

D.S. al $\Phi$ e fine 

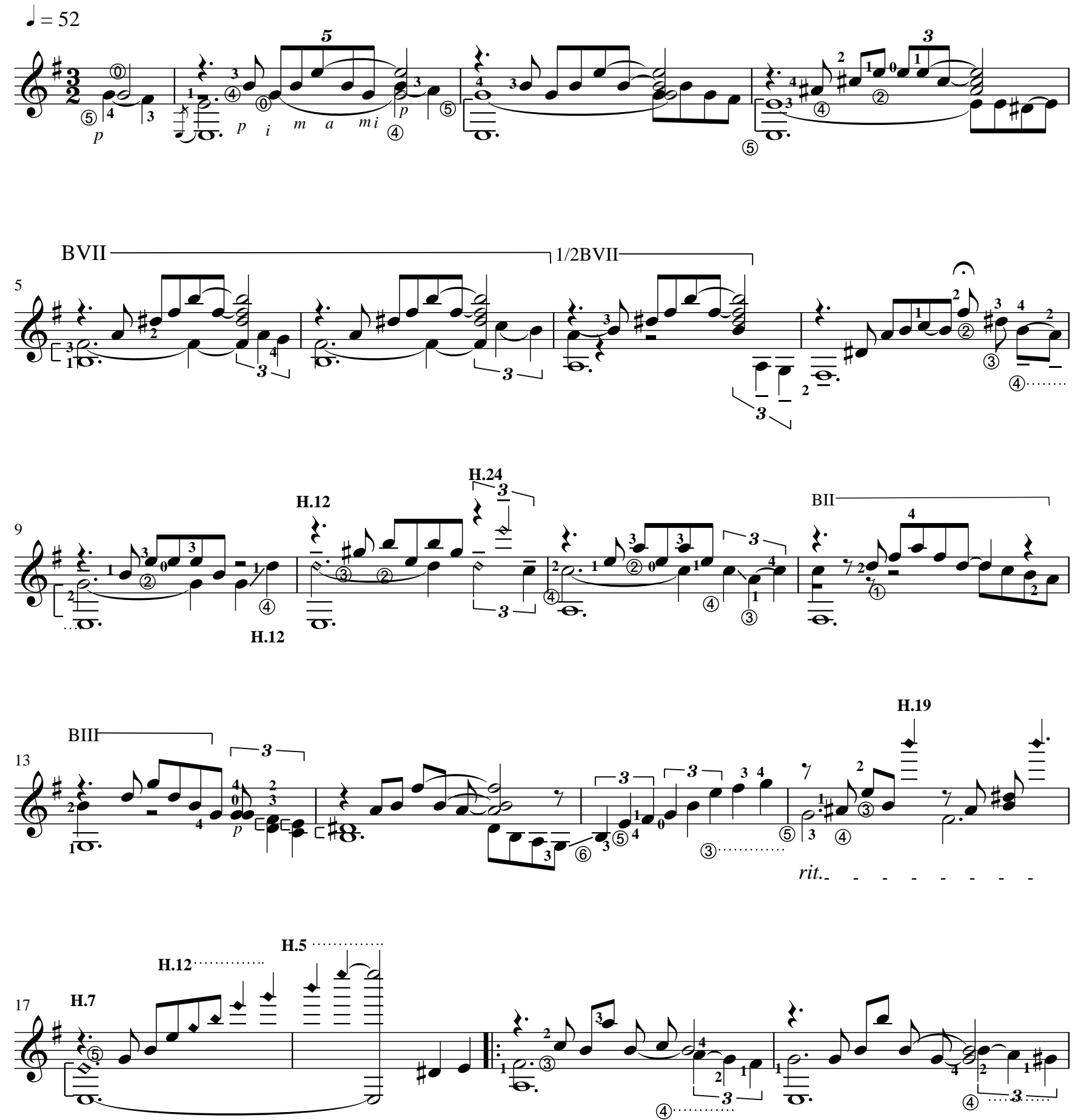

rall. - - - - a tempo

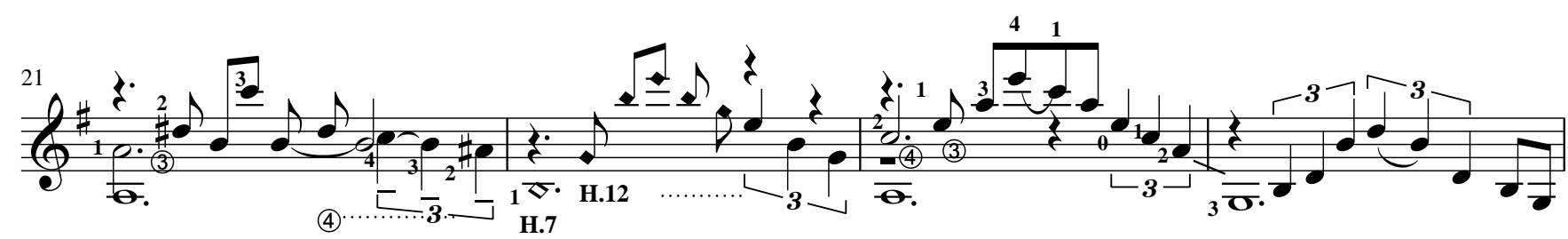



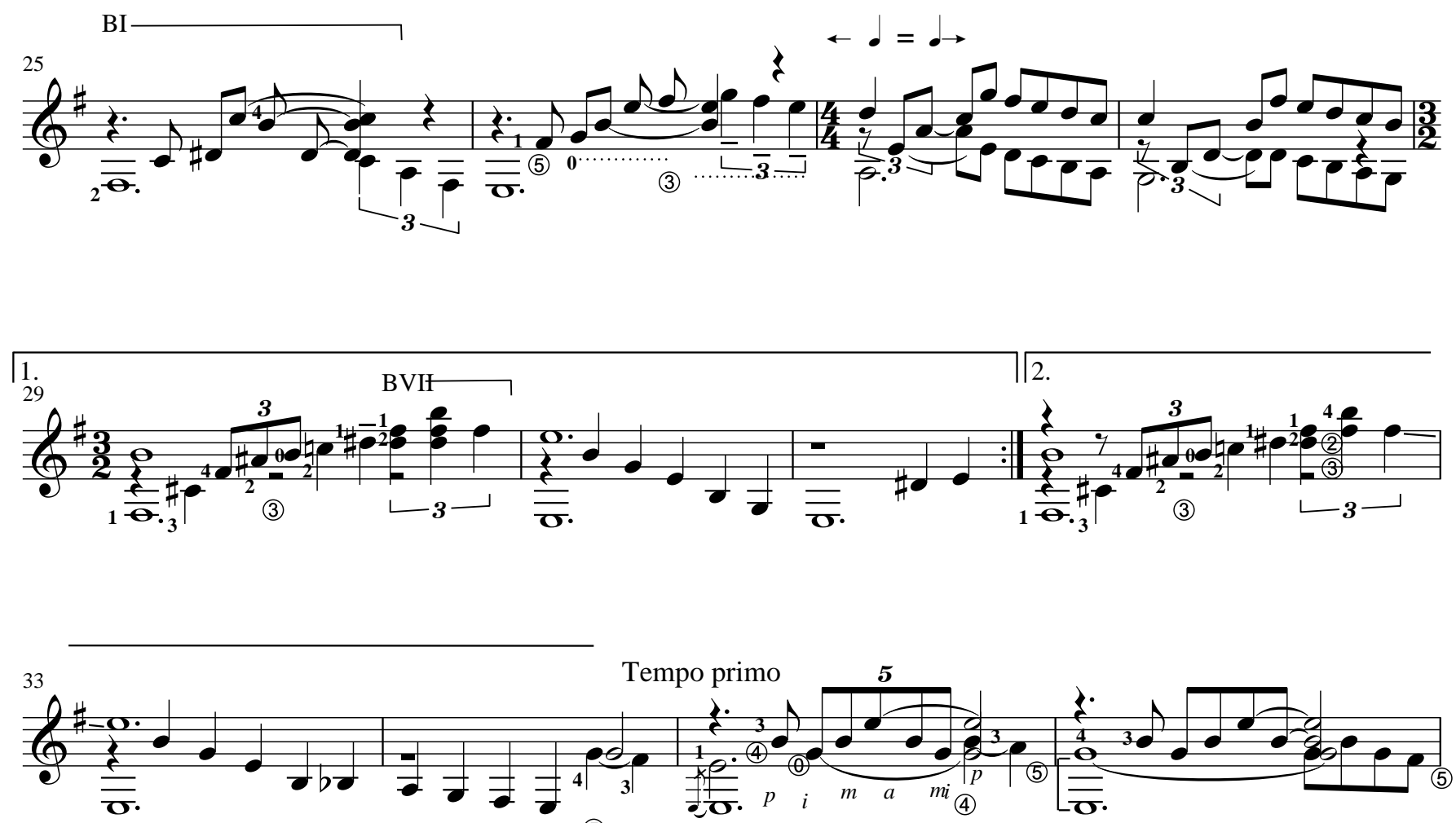
rall. _ _ $\bigodot_{-}^{(5)}$
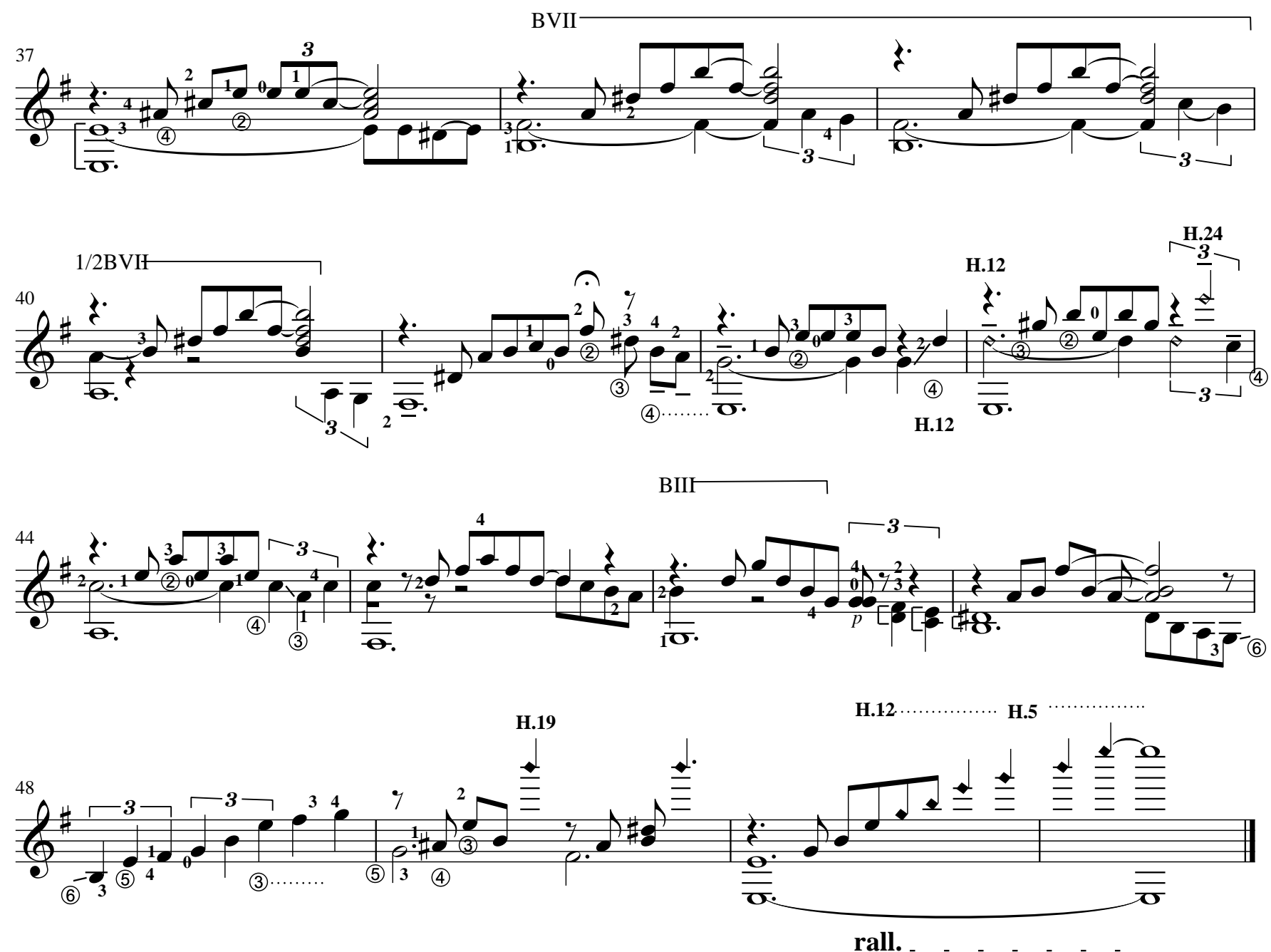
Devaneío

195

Extraída e digitada

Othon Salleiro

a partir da gravação

do compositor (1950)

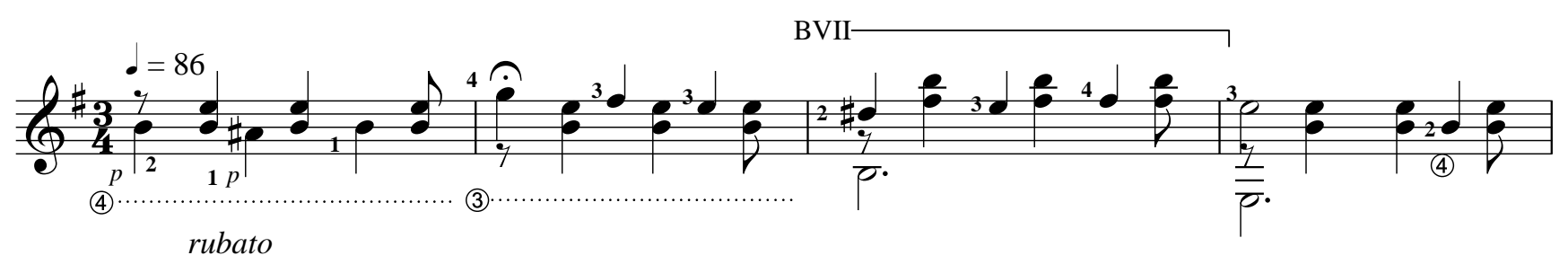

(4)
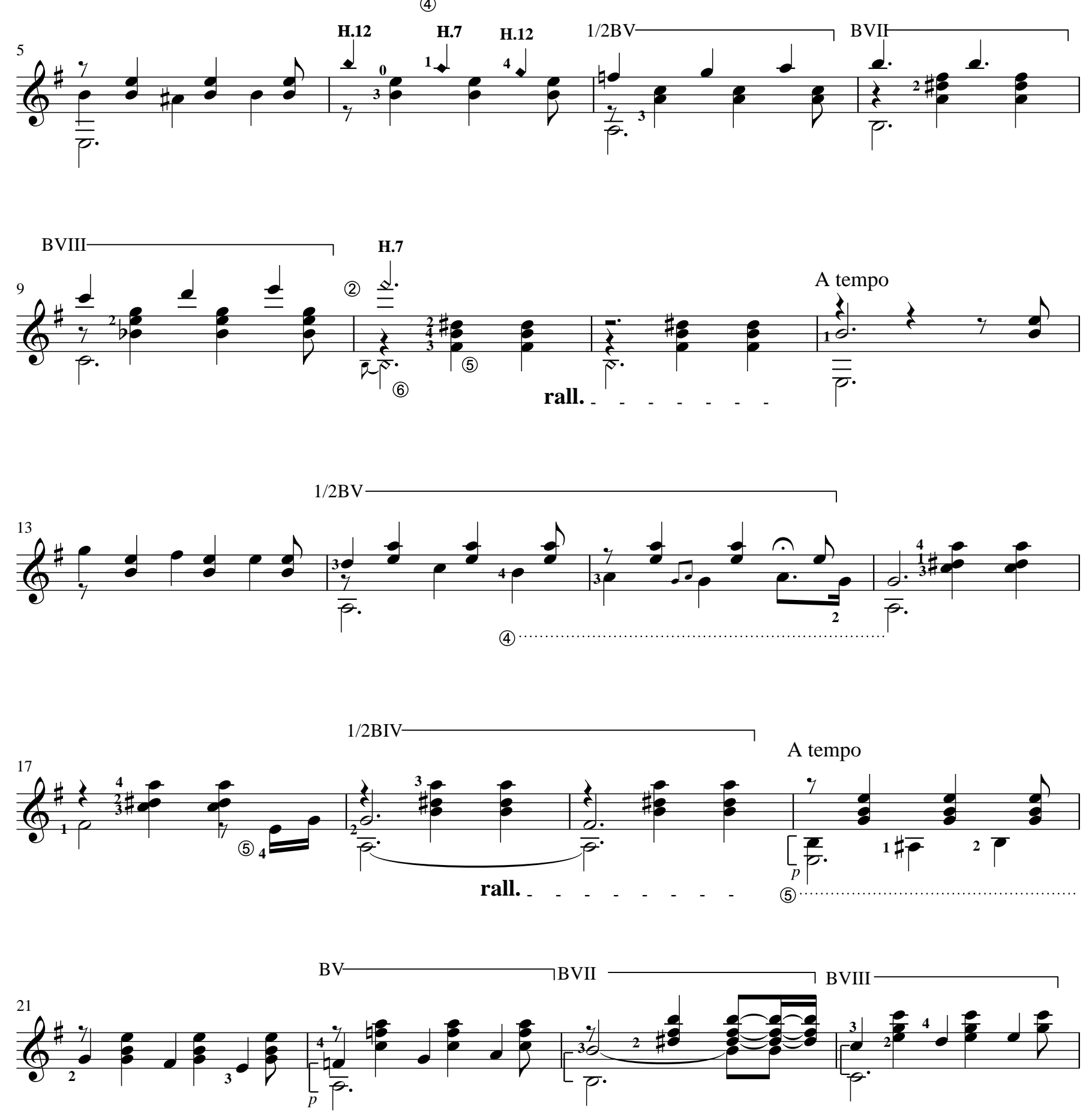

Partitura confeccionada para a dissertação de mestrado: Othon Salleiro: Um Barrios brasileiro?

Flavia Prando - ECA/USP - 2008 

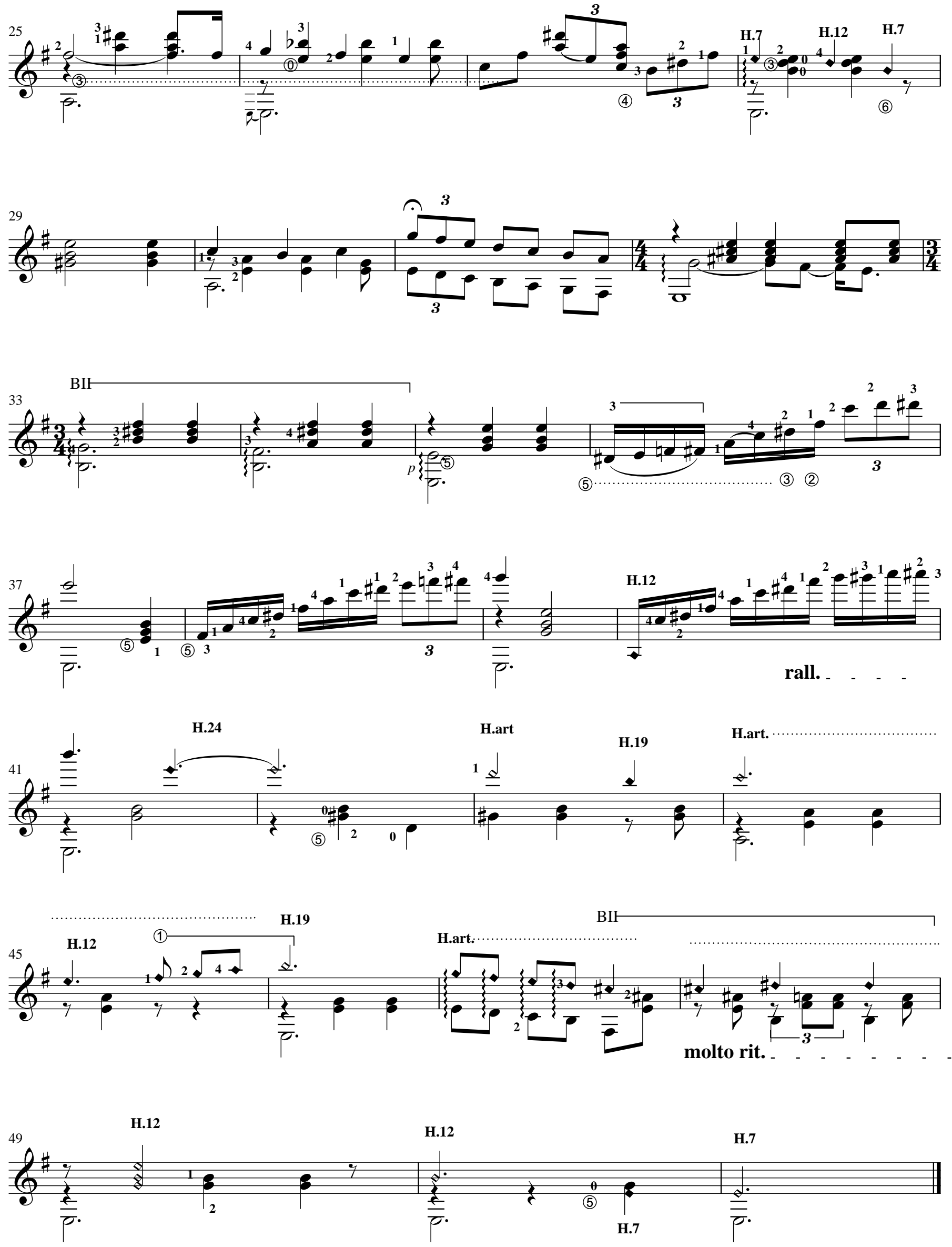

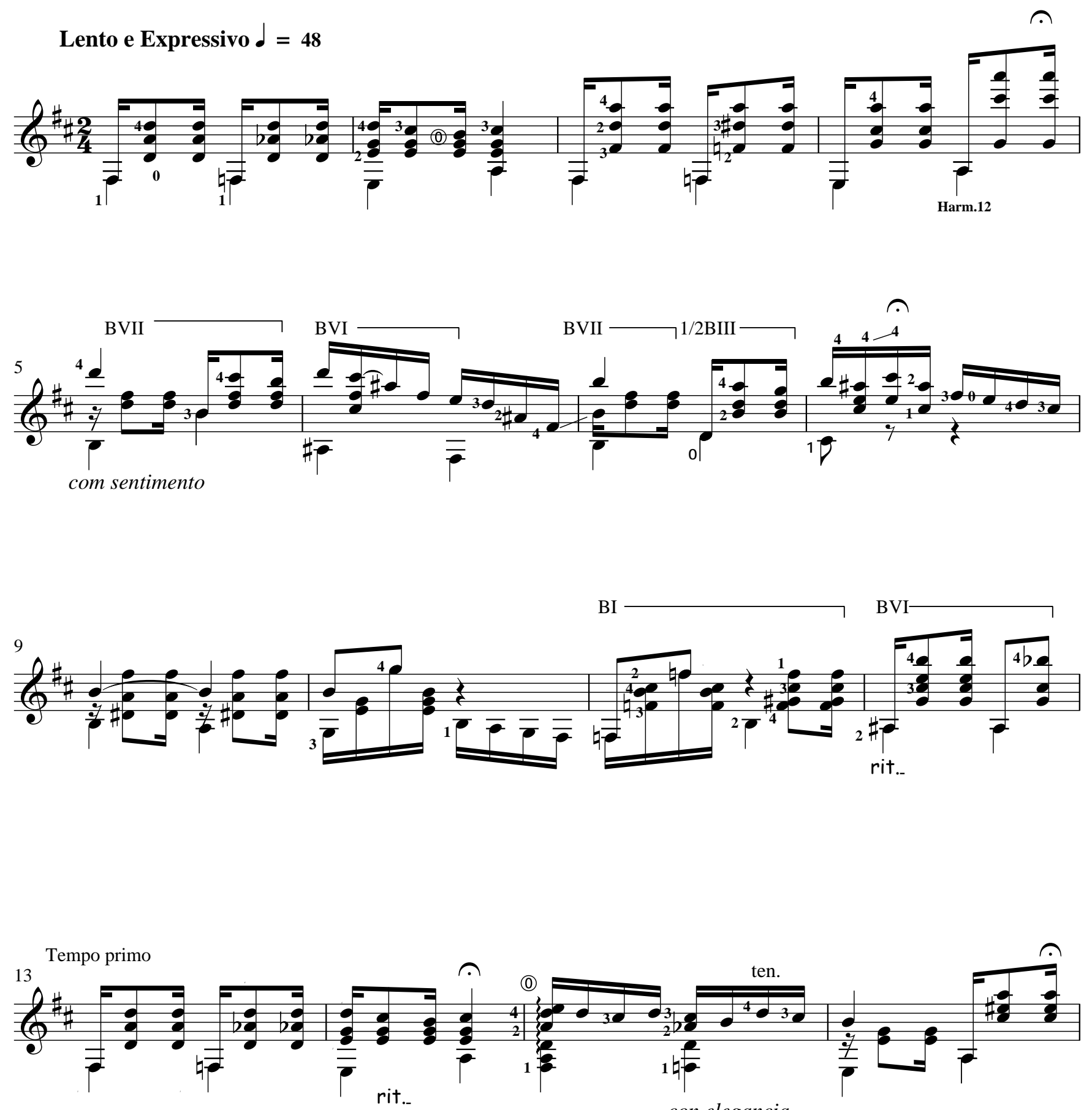

con elegancia

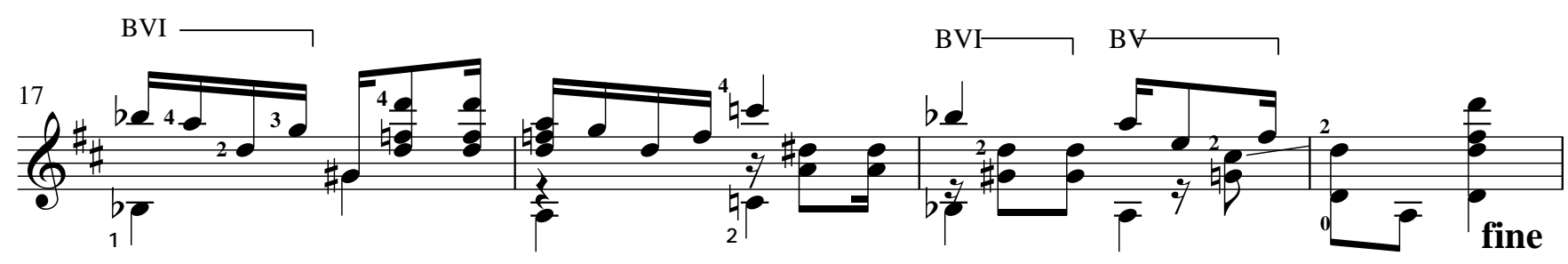


Allegro moderato $\_\mathbf{~} \mathbf{7 0}$
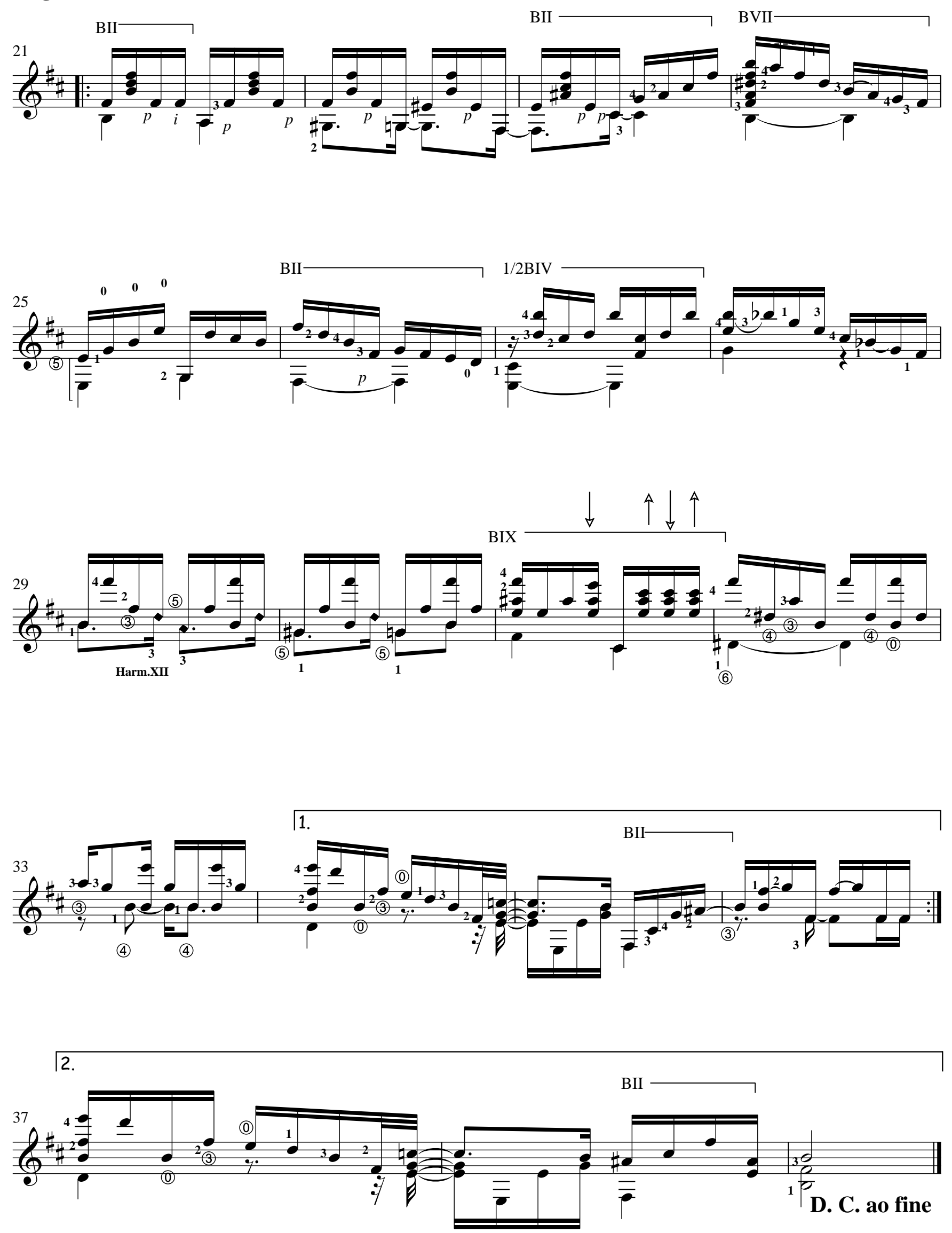

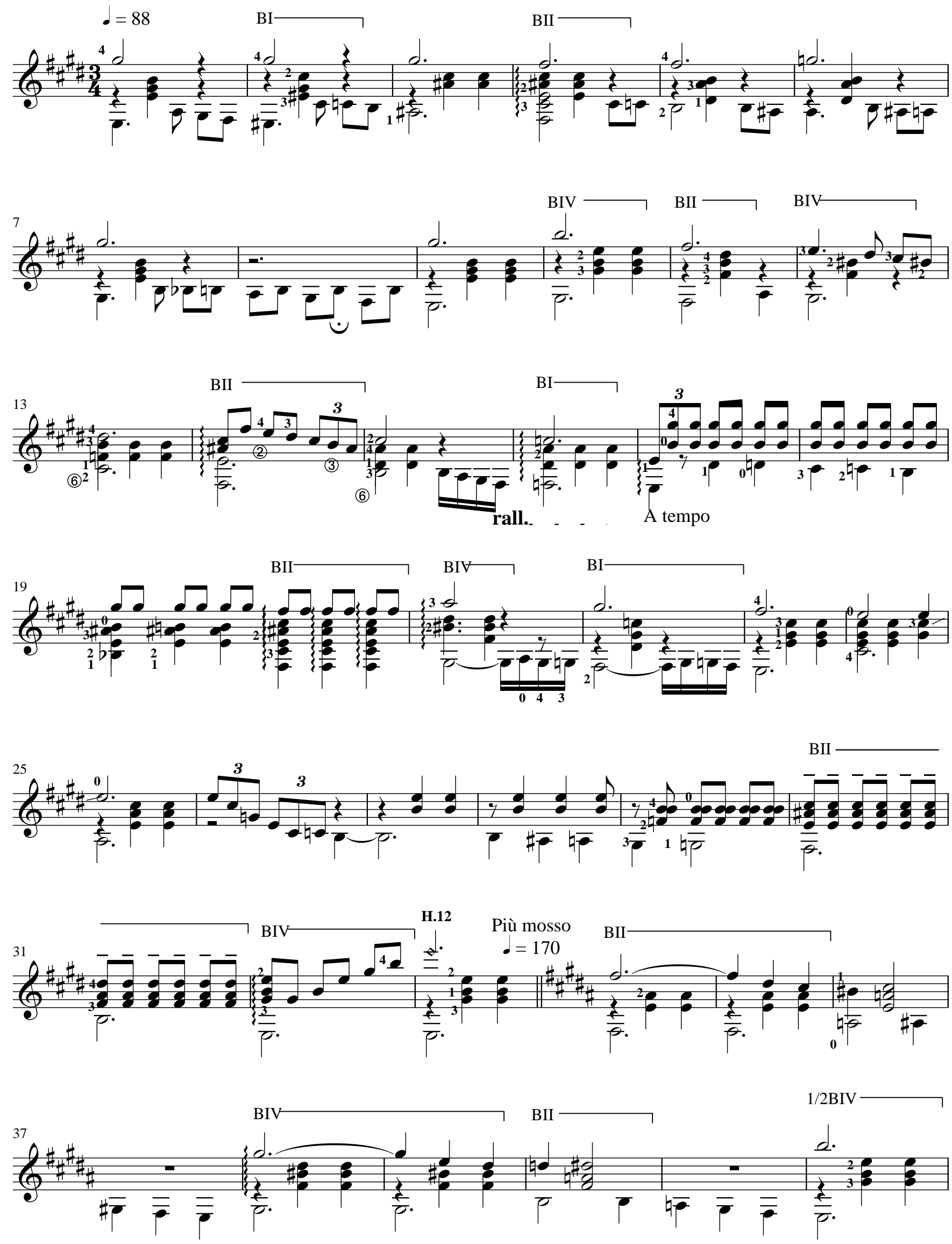

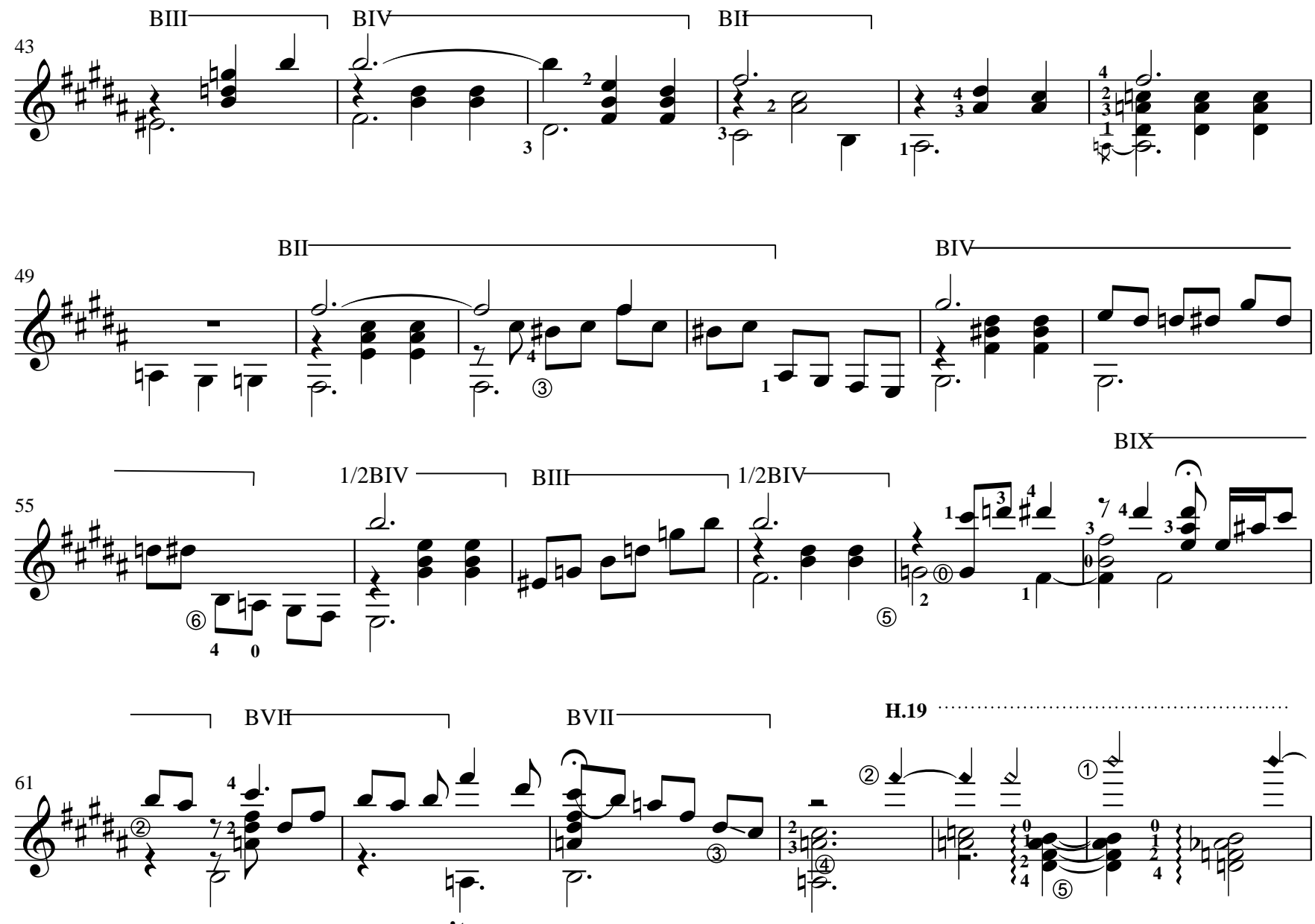
rit. molto rall.
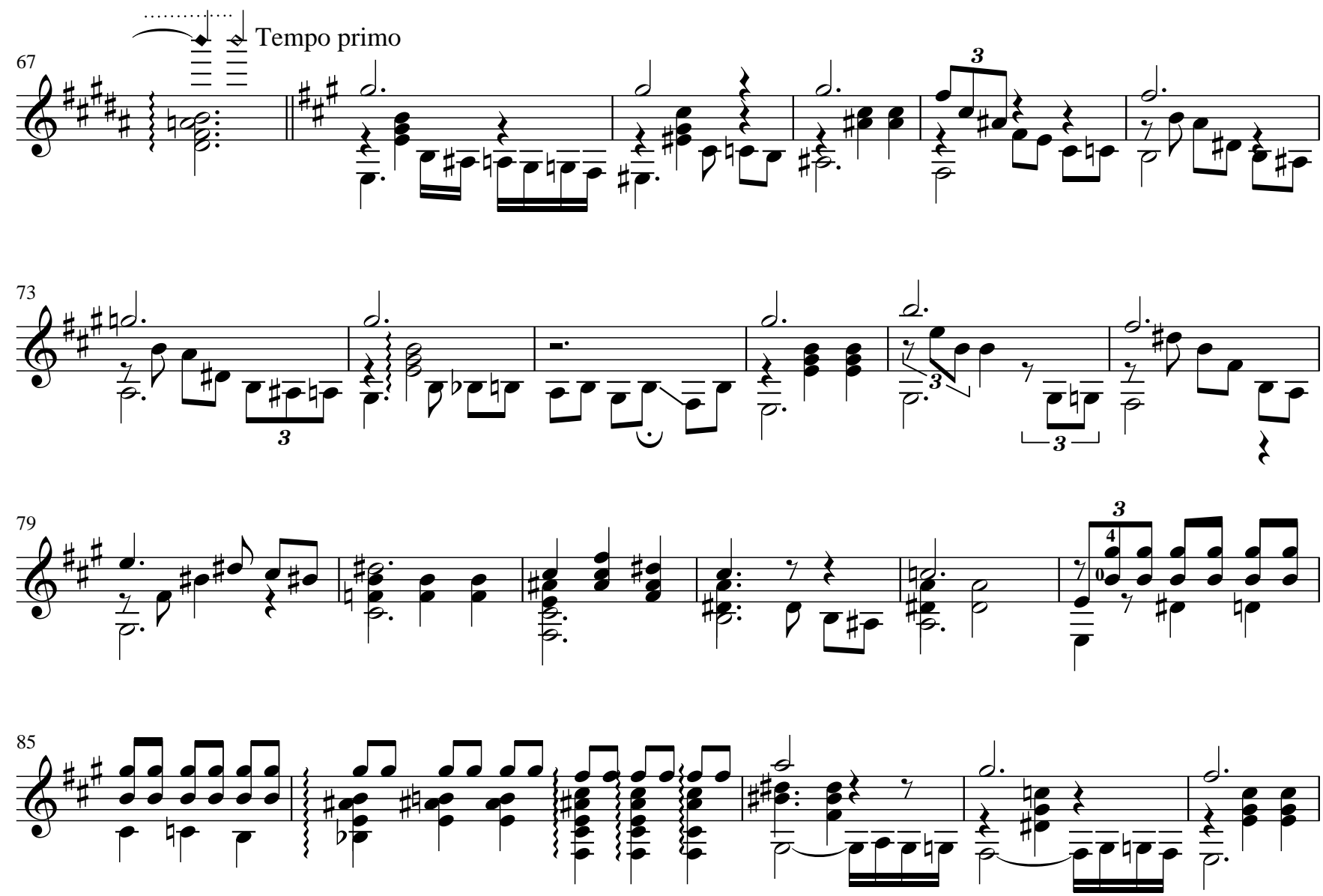

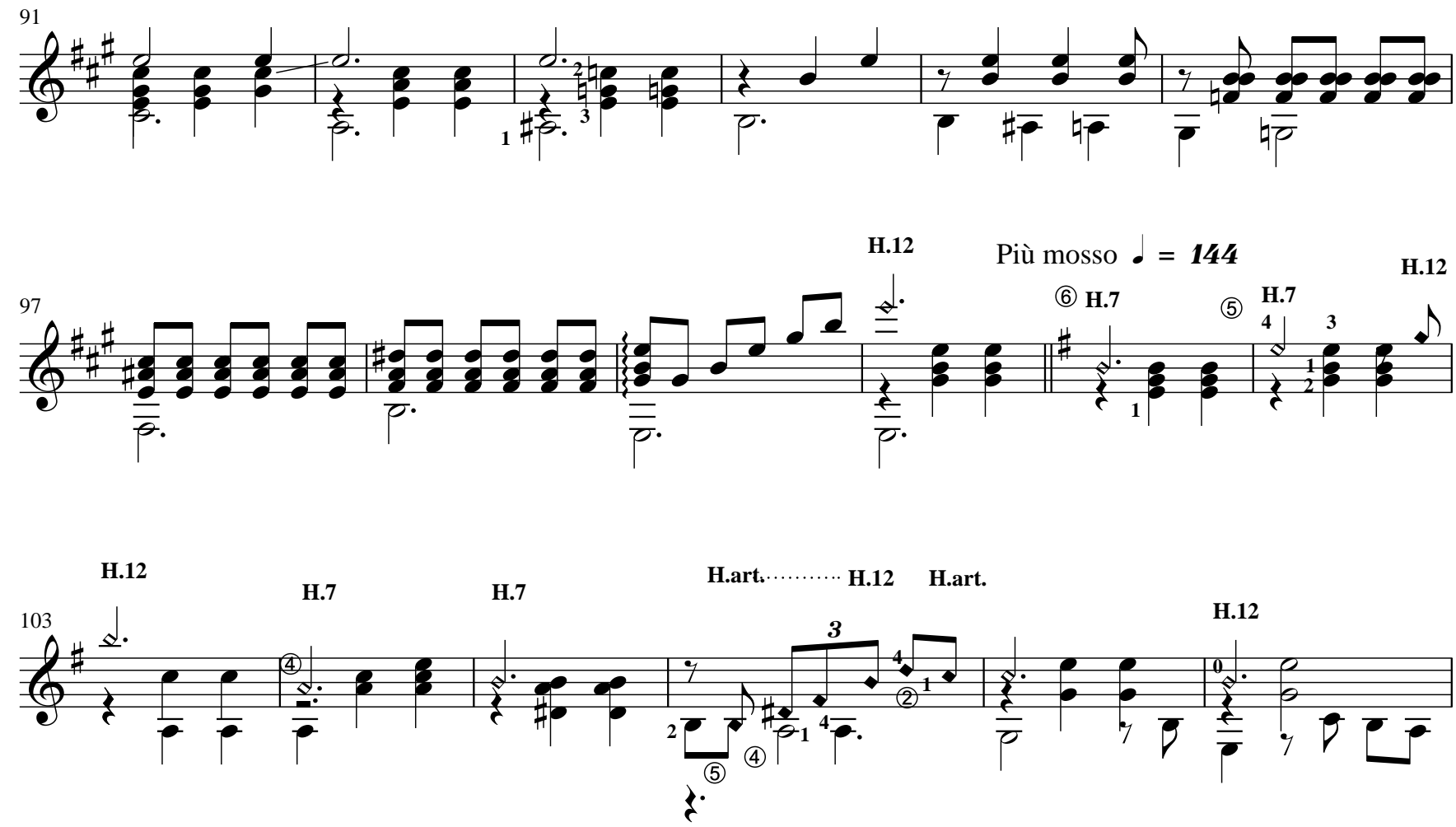

H.12

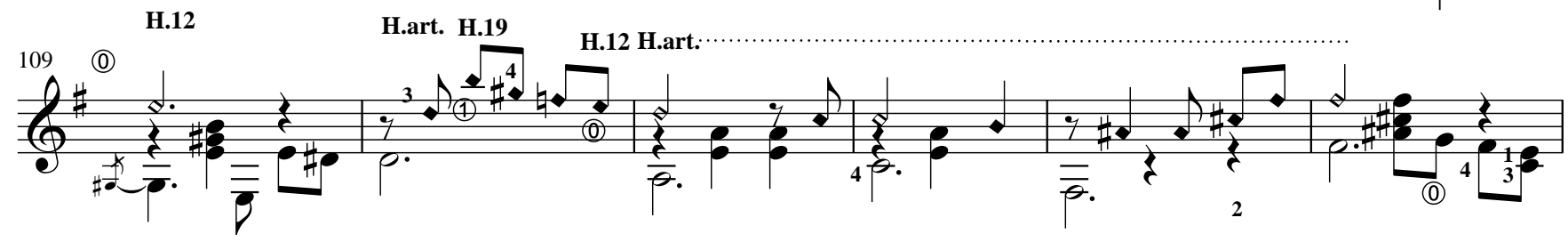

$\begin{array}{lll}\text { H.art........... H.19 H.art: } & \text { H. }\end{array}$
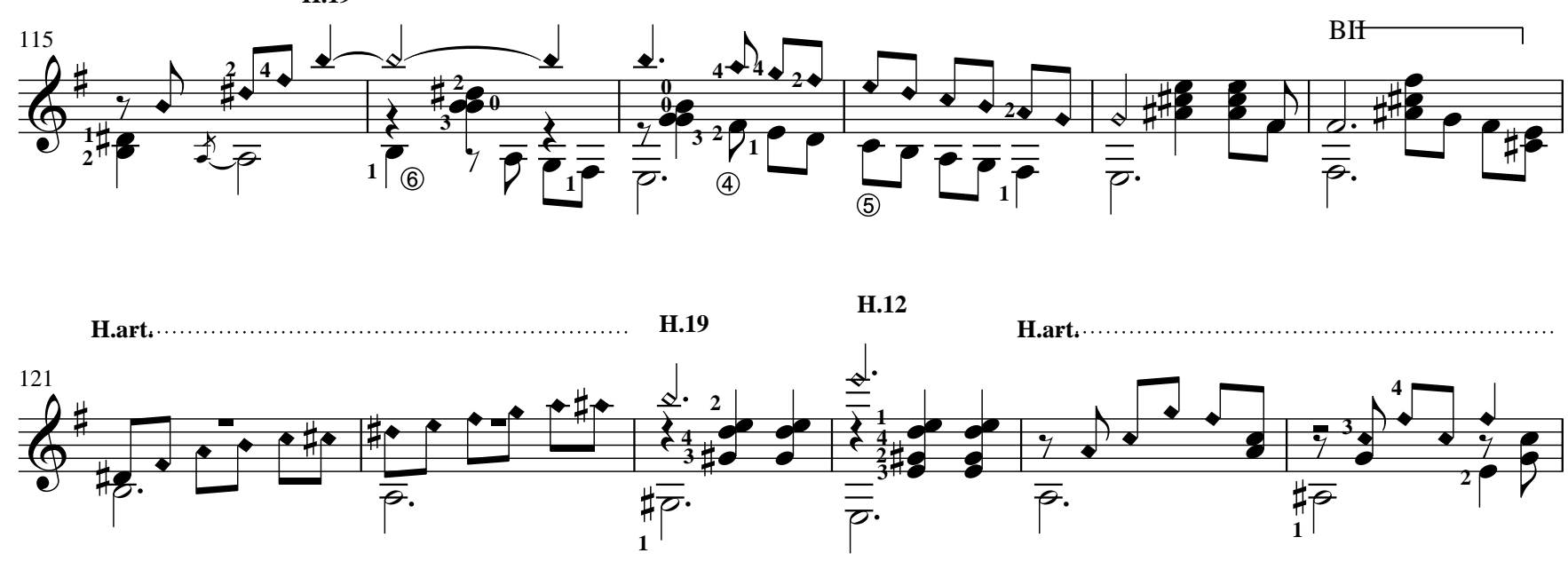

H.art.

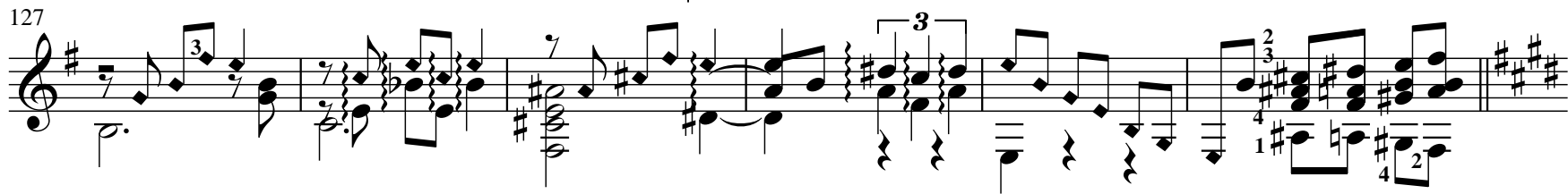




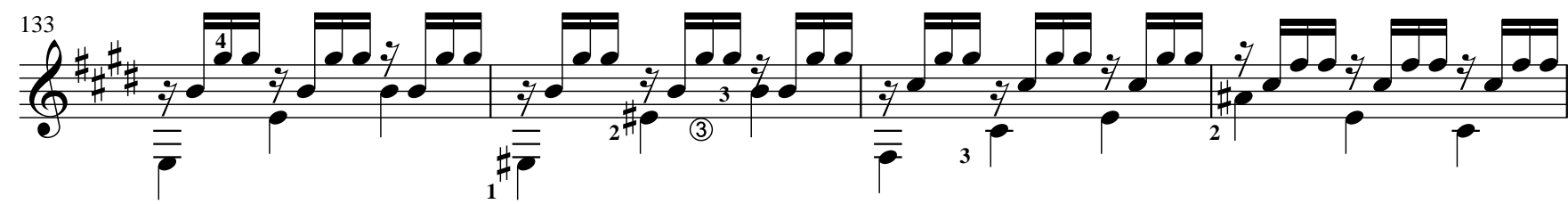

$\mathrm{BIV} \longrightarrow$ BVIঙ

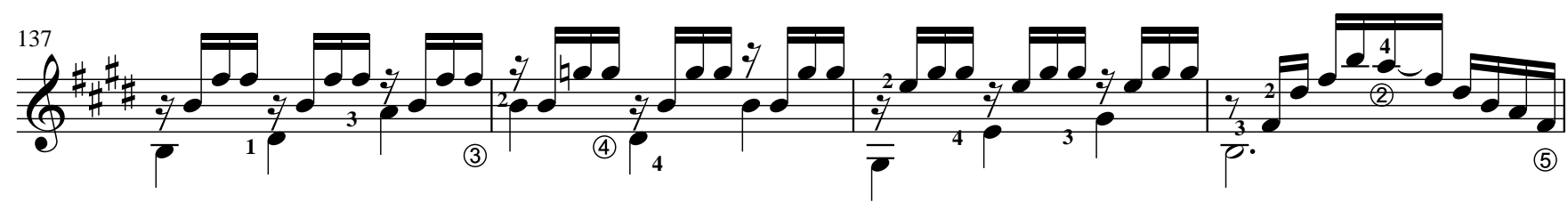

BIV

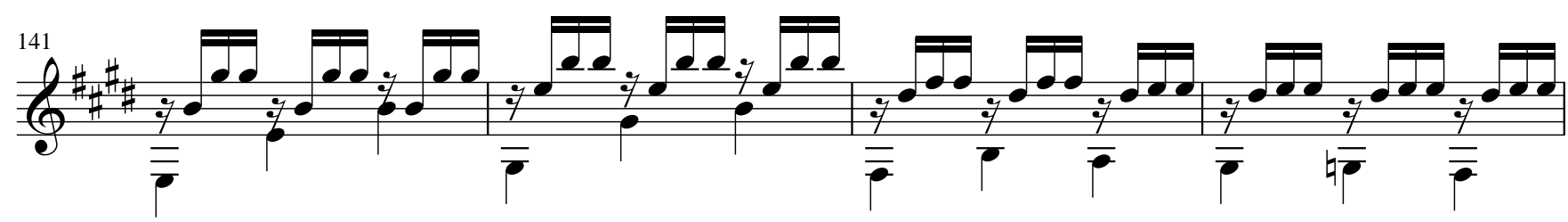

$\mathrm{BI} \longrightarrow \mathrm{BII} \longrightarrow$

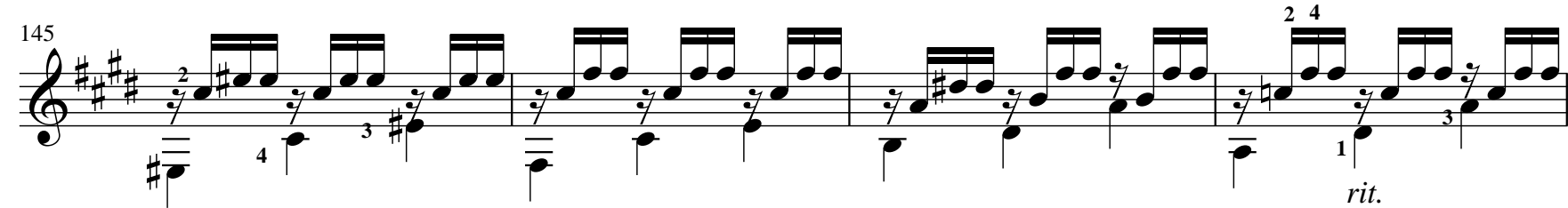

a tempo

$\mathrm{BI} \longmapsto$

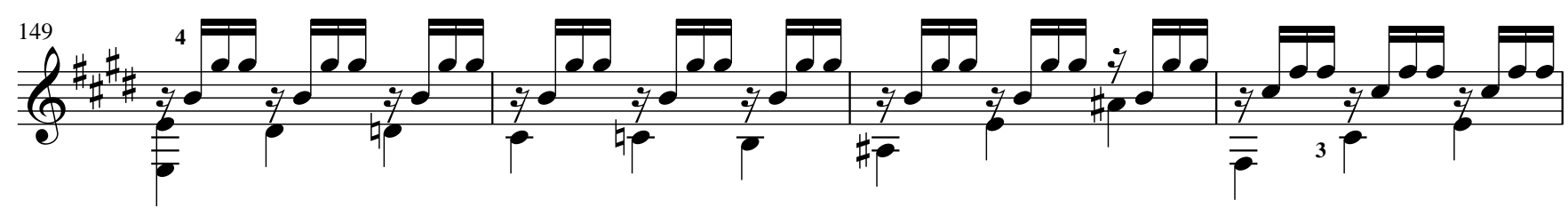

Tempo primo
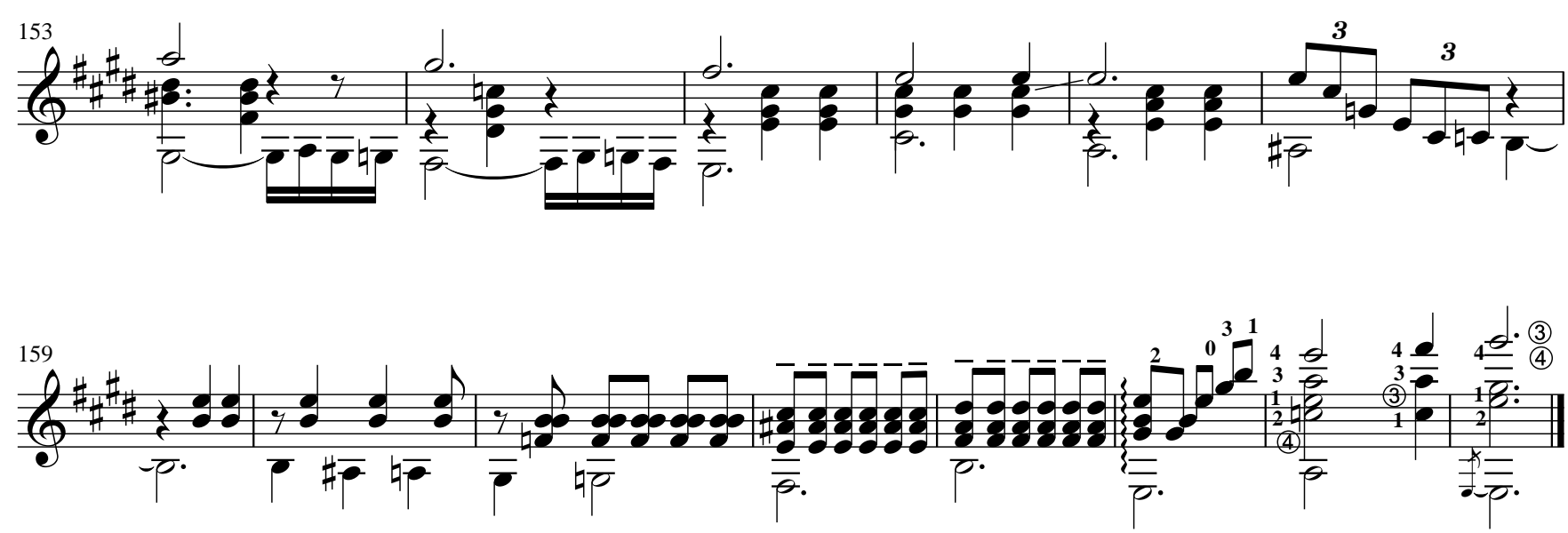

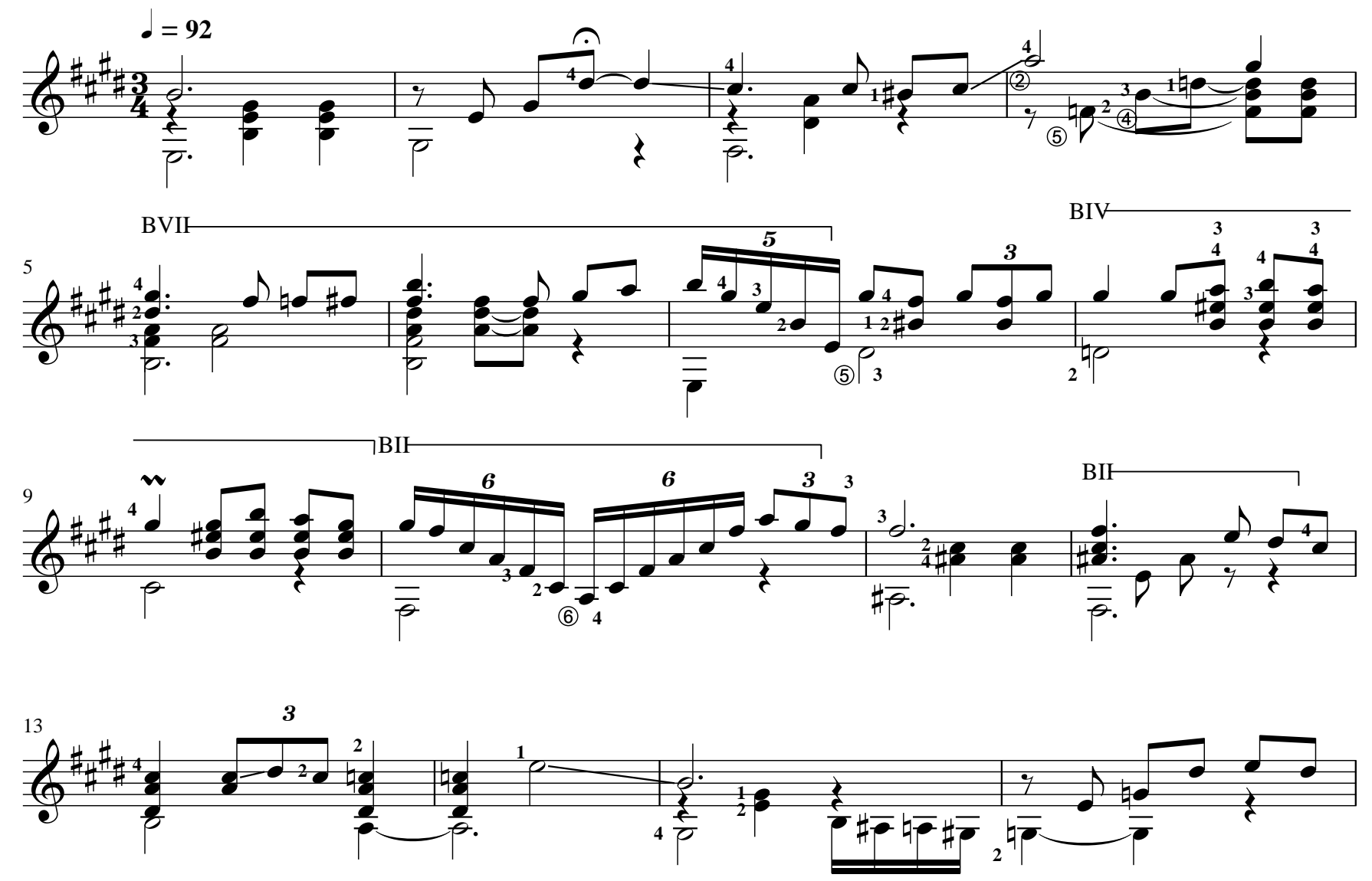

BVIF
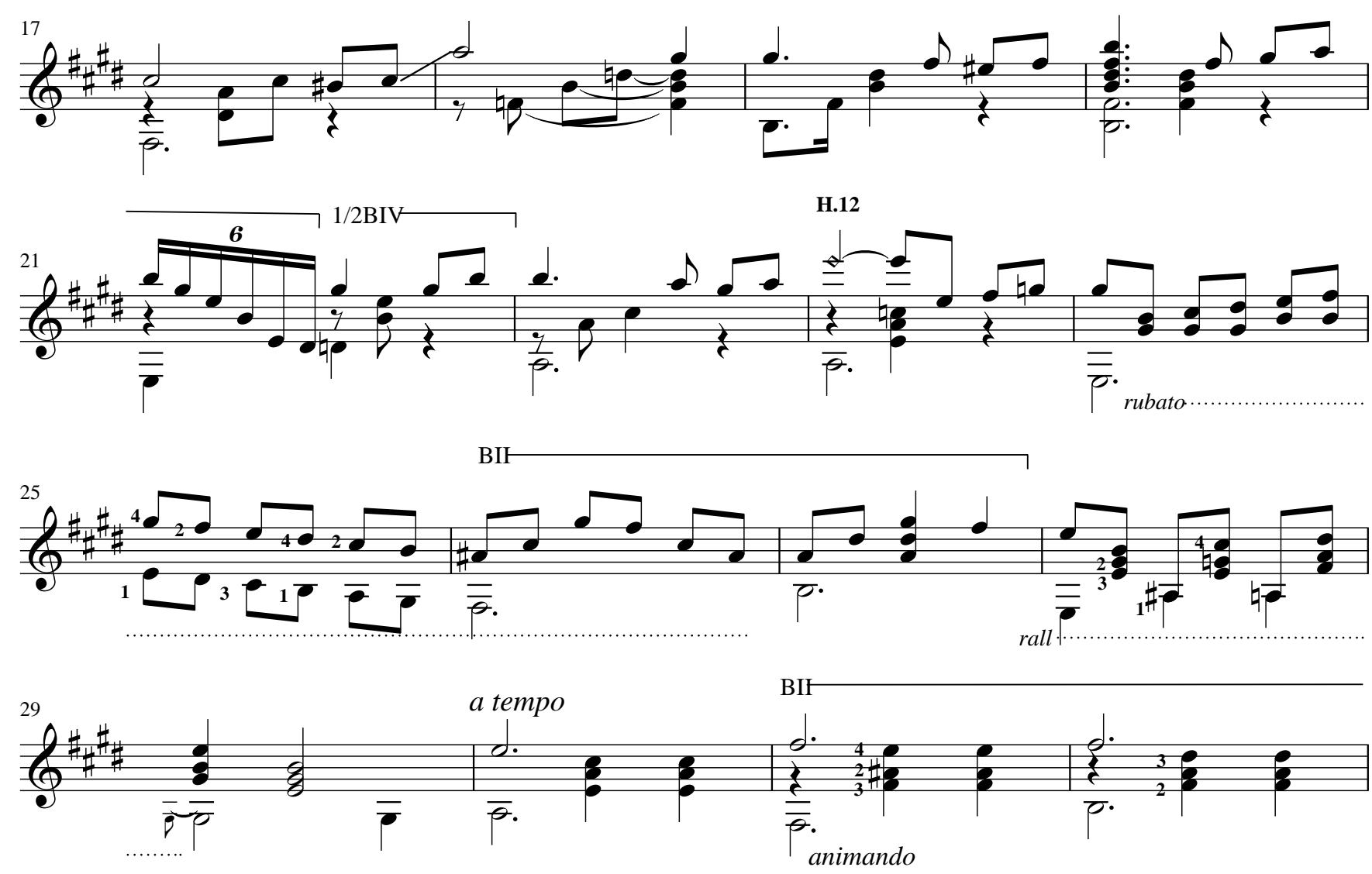

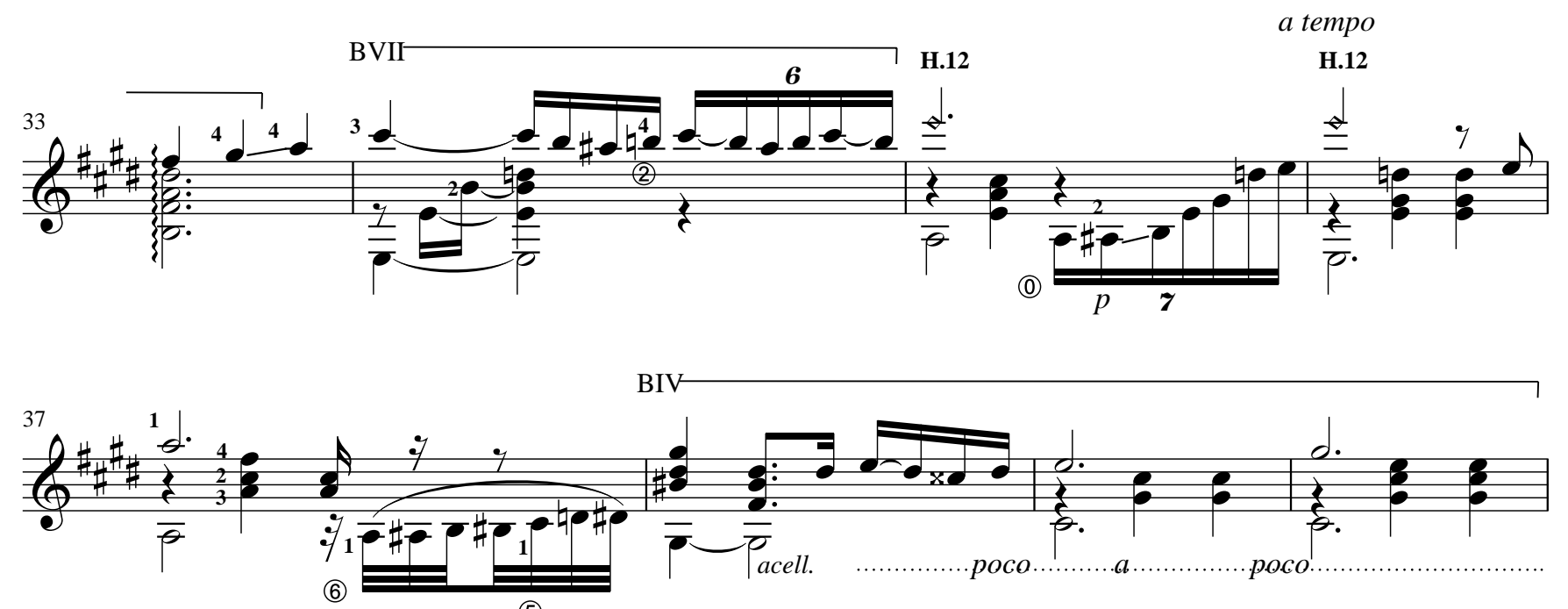

(6)

(5)
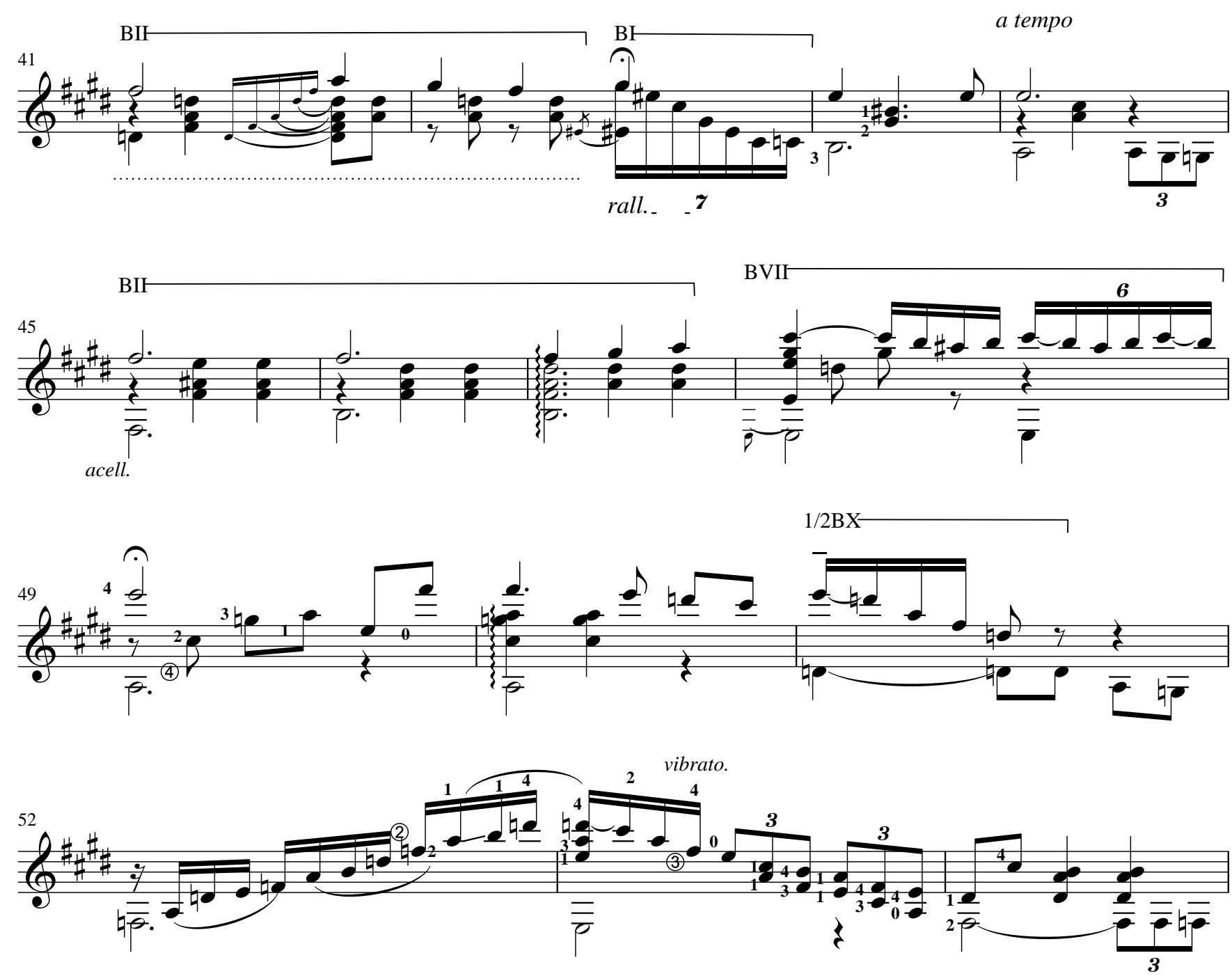

a tempo

H.12

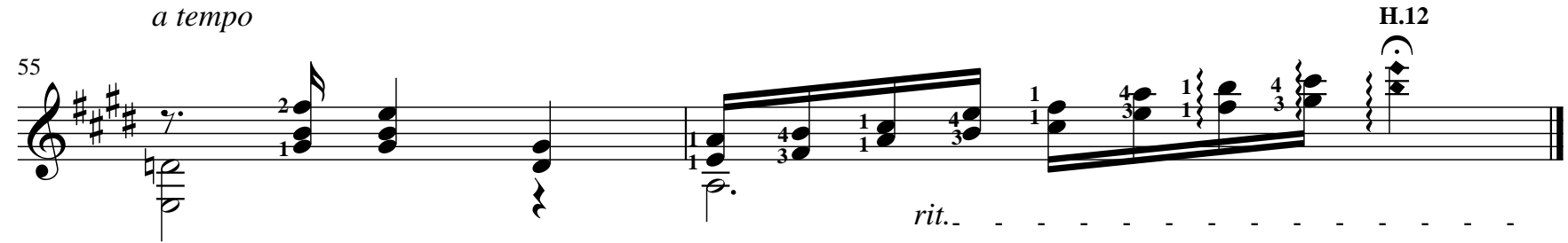


Extraída e digitada

Festa do Bonfim

205

a partir da gravação

Othon Salleiro

do compositor
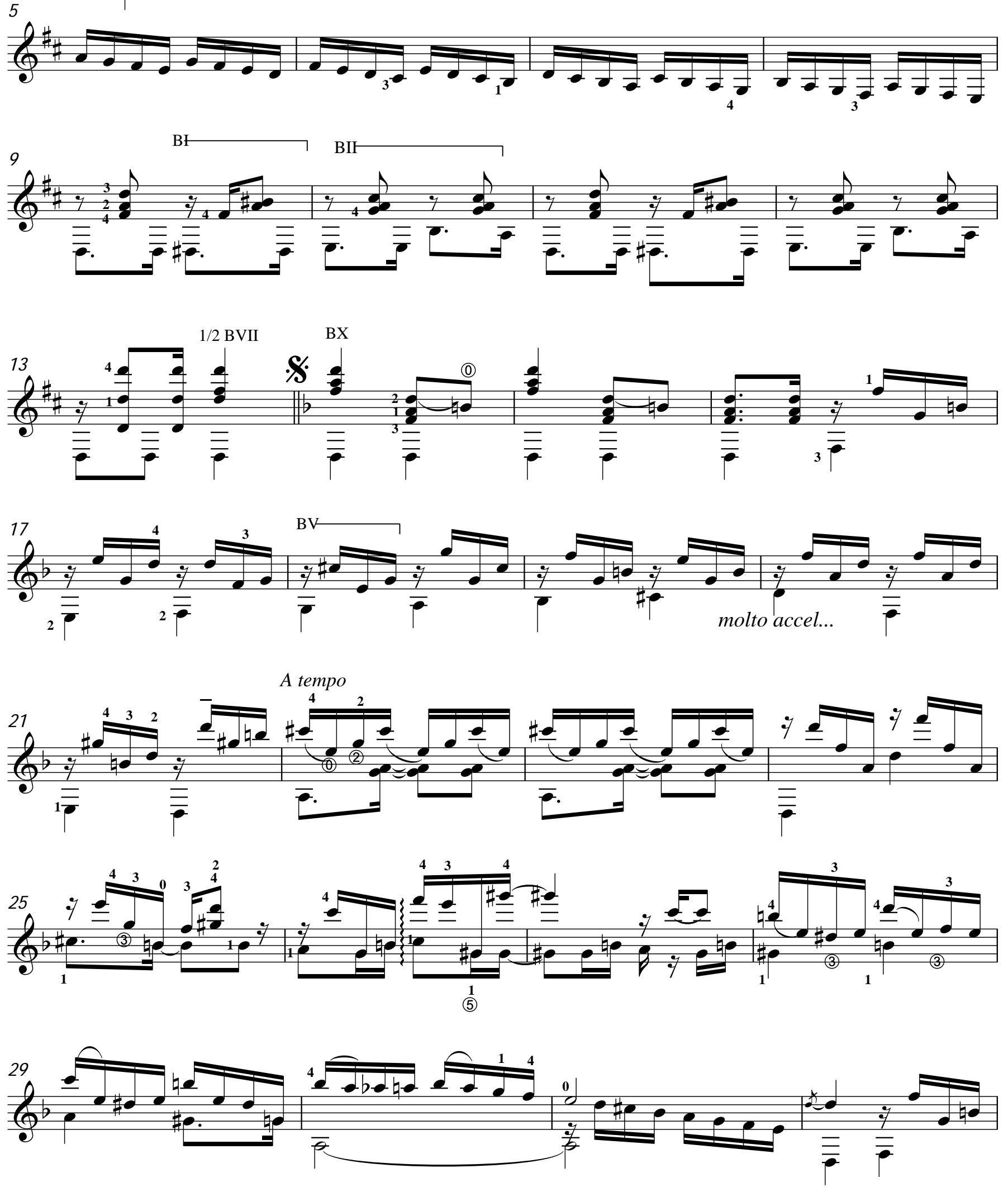

Partitura confeccionada para a dissertação de mestrado: Othon Salleiro: Um Barrios brasileiro?

Flavia Prando - ECA/USP - 2008 

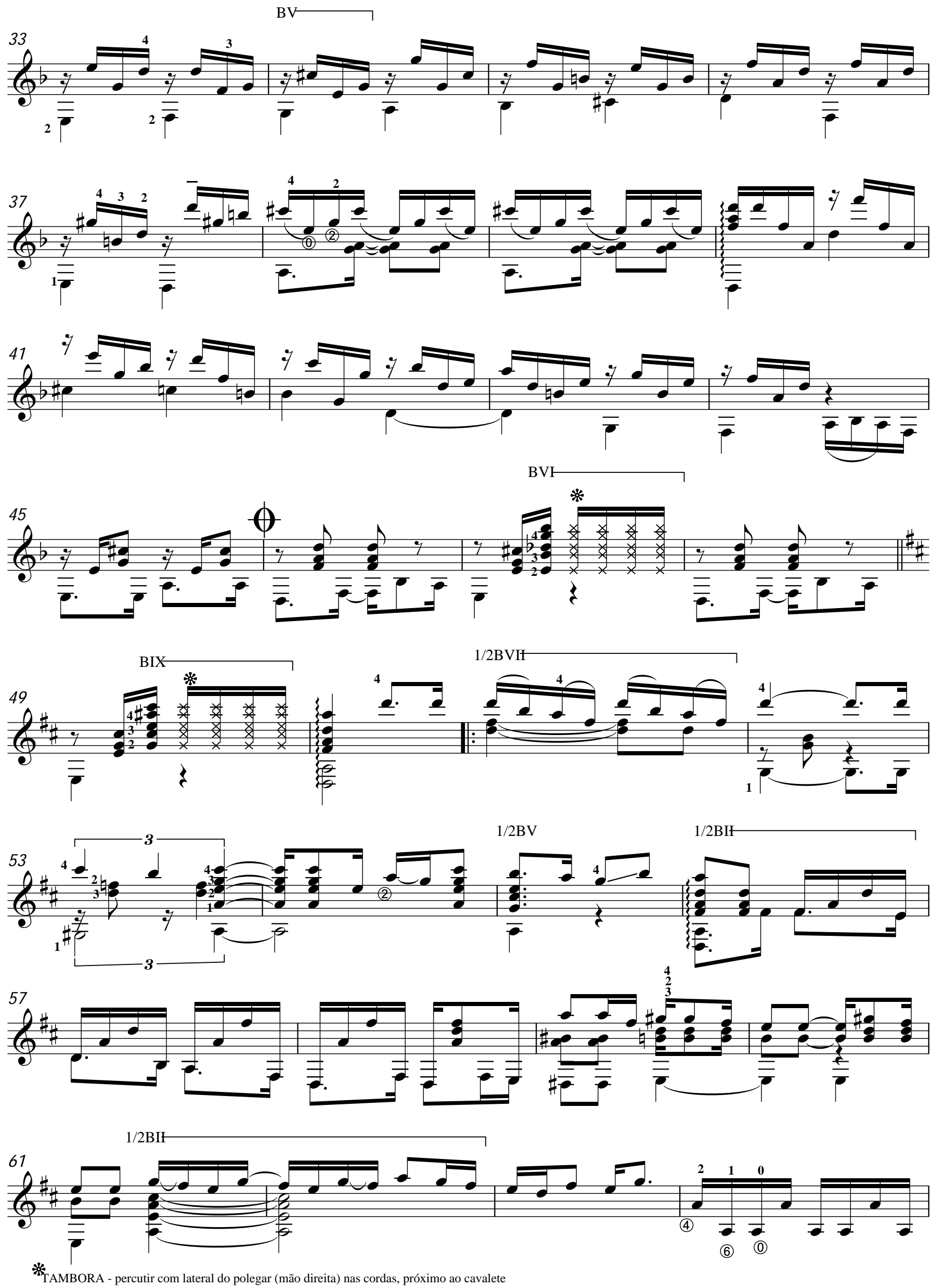

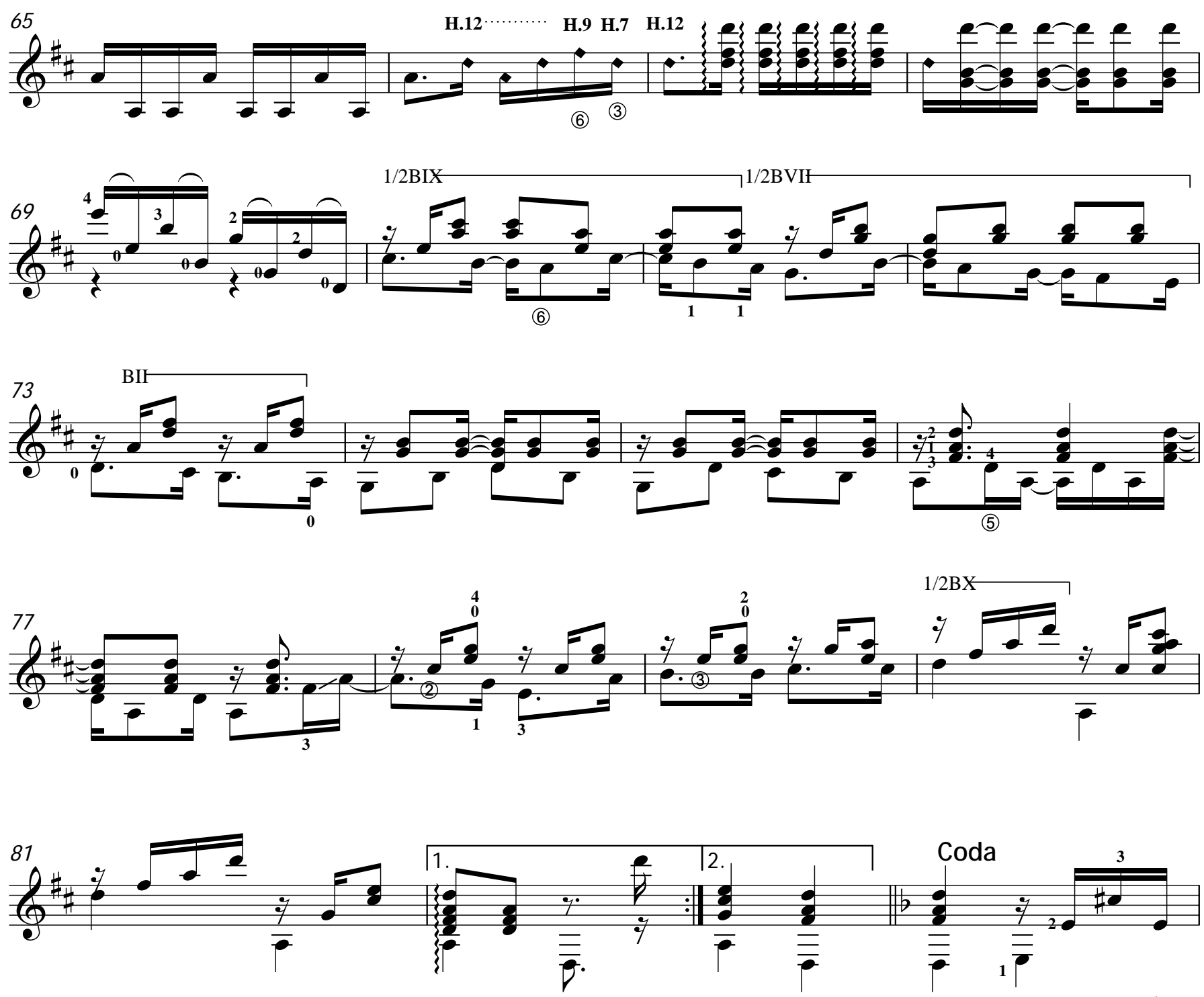

Do $\$$. al $\oplus$ e coda
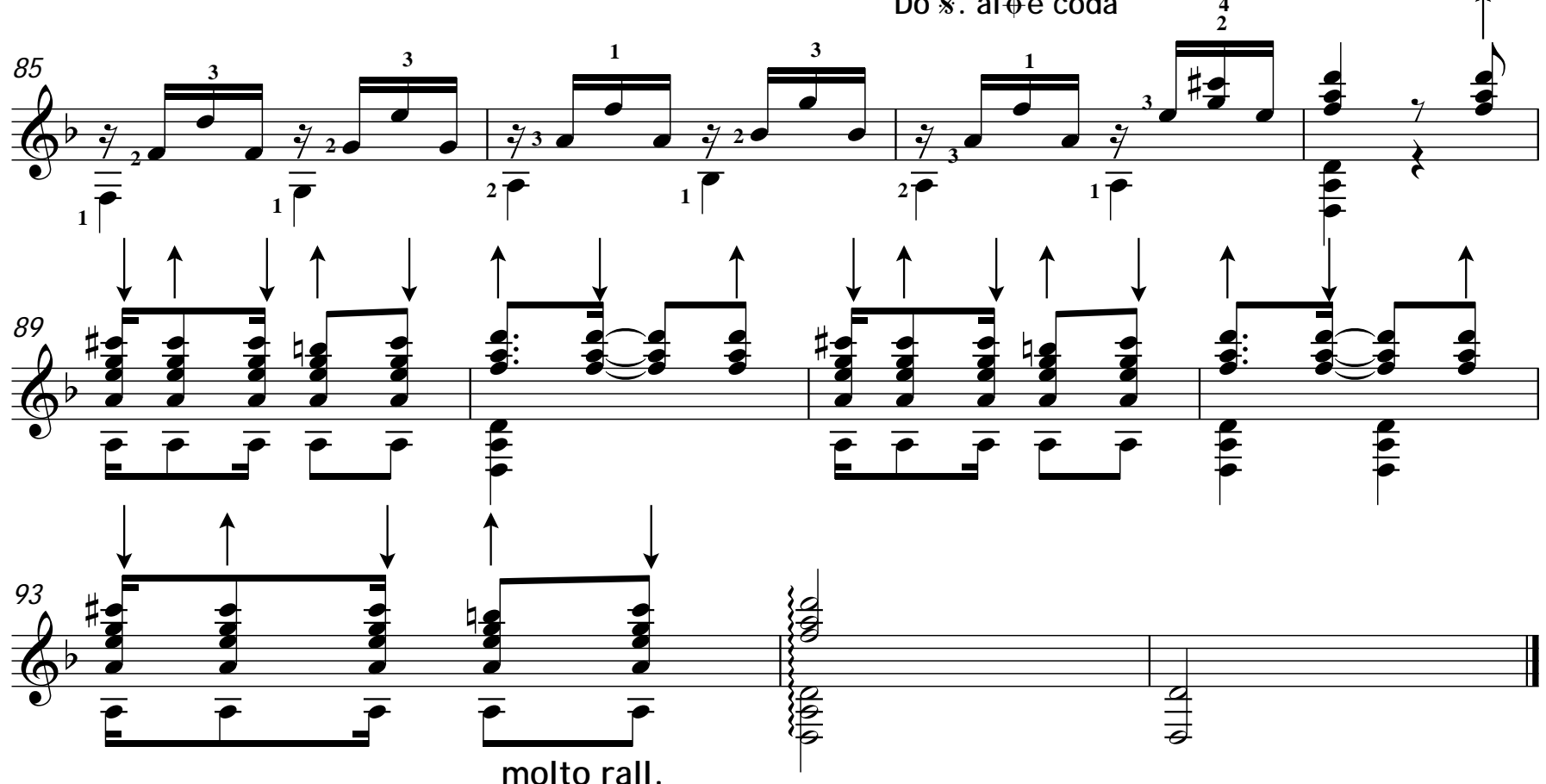

Partitura confeccionada para a dissertação de mestrado: Othon Salleiro: Um Barrios brasileiro? Flavia Prando - ECA/USP - 2008 

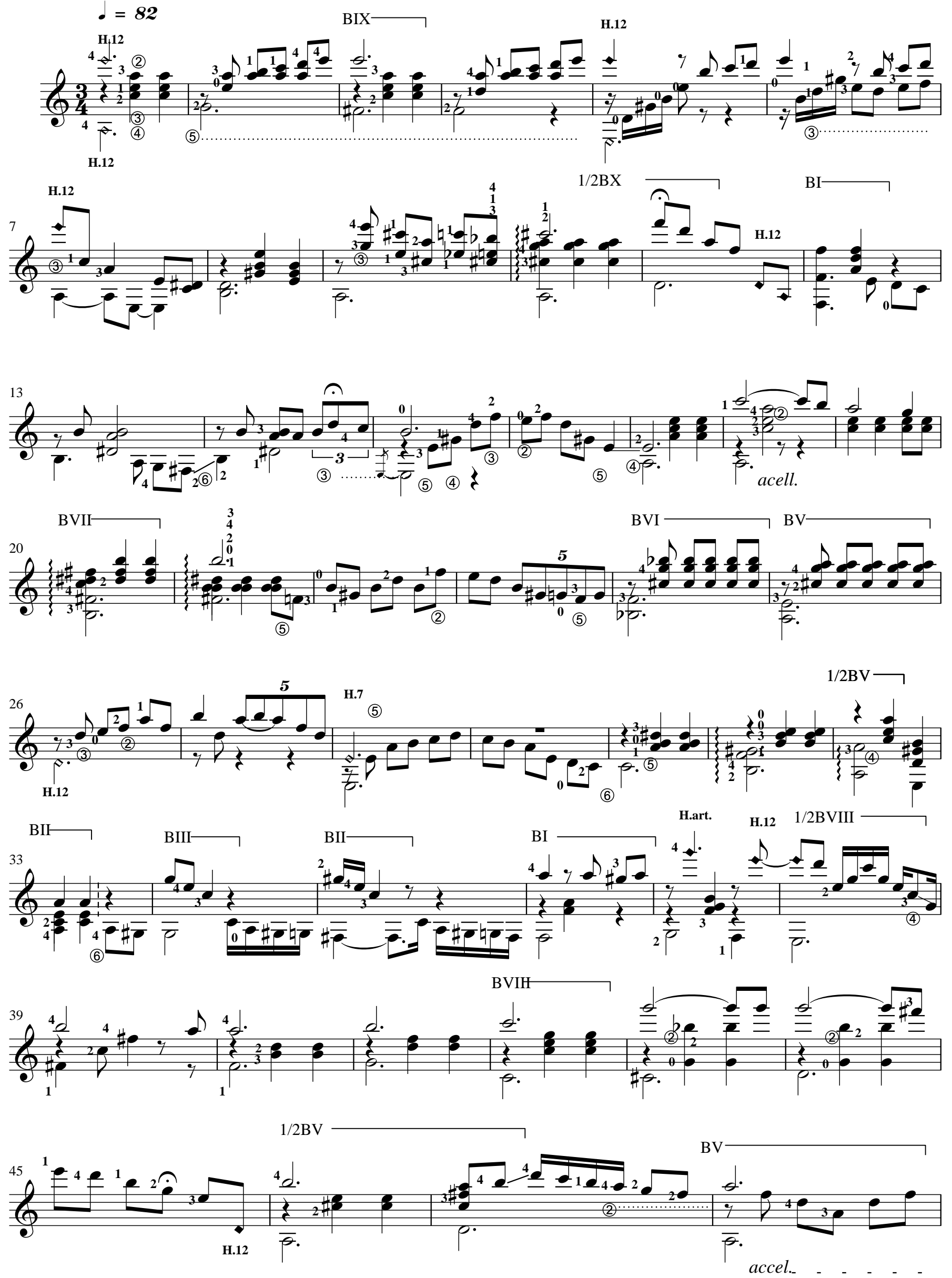
Luar dos Trópicos continuação

209

2

Othon Salleiro
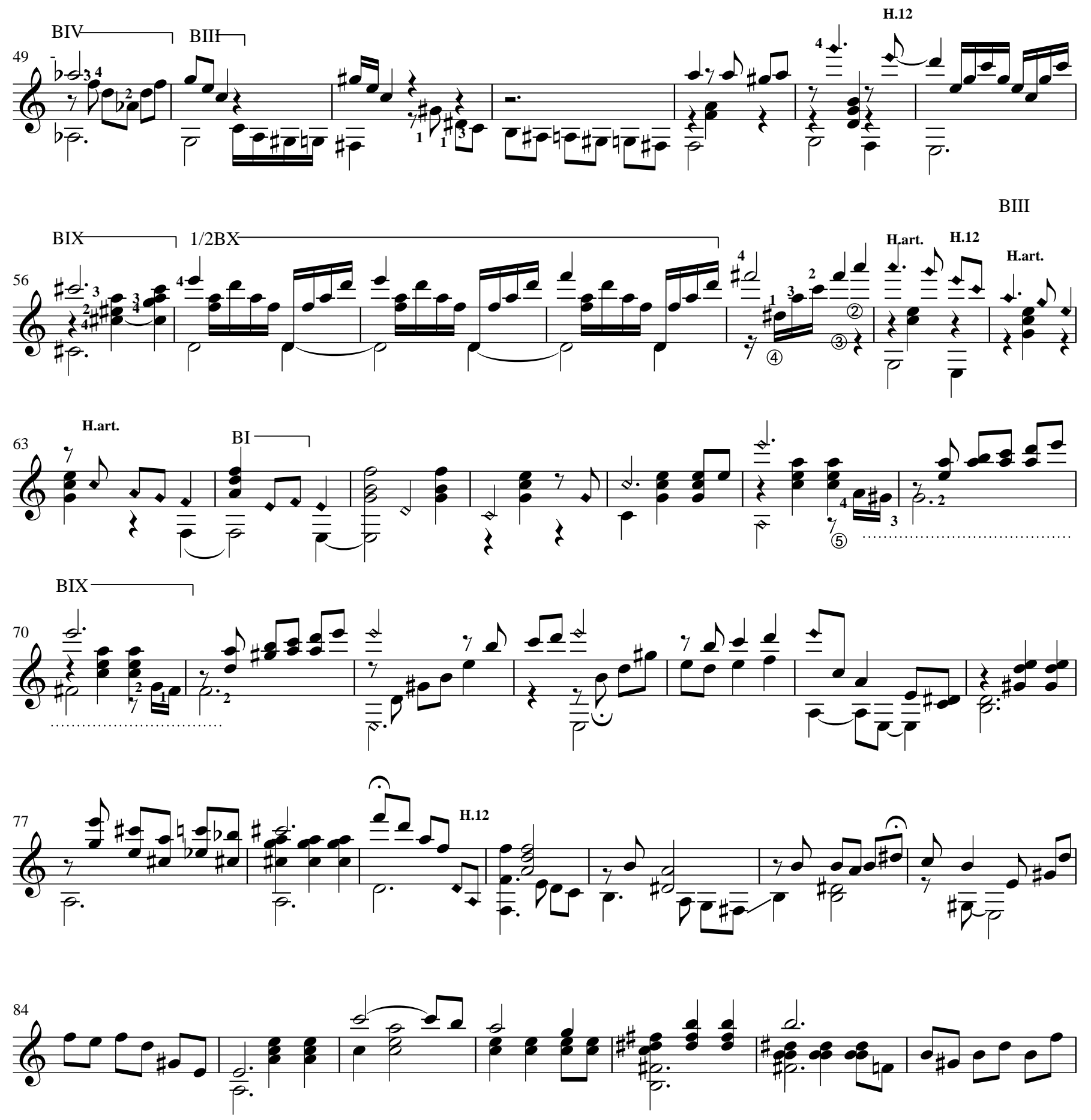

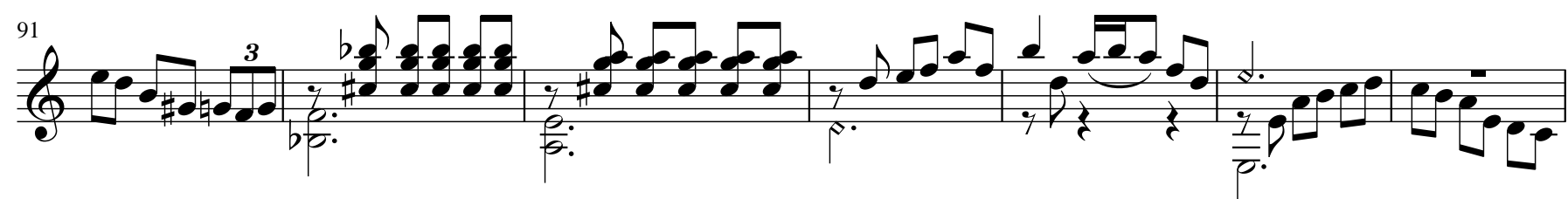

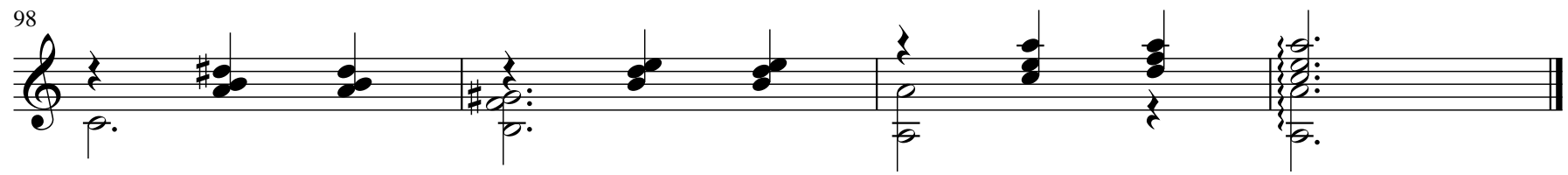

Partitura confeccionada para a dissertação de mestrado: Othon Salleiro: Um Barrios brasileiro?

Flavia Prando - ECA/USP - 200 

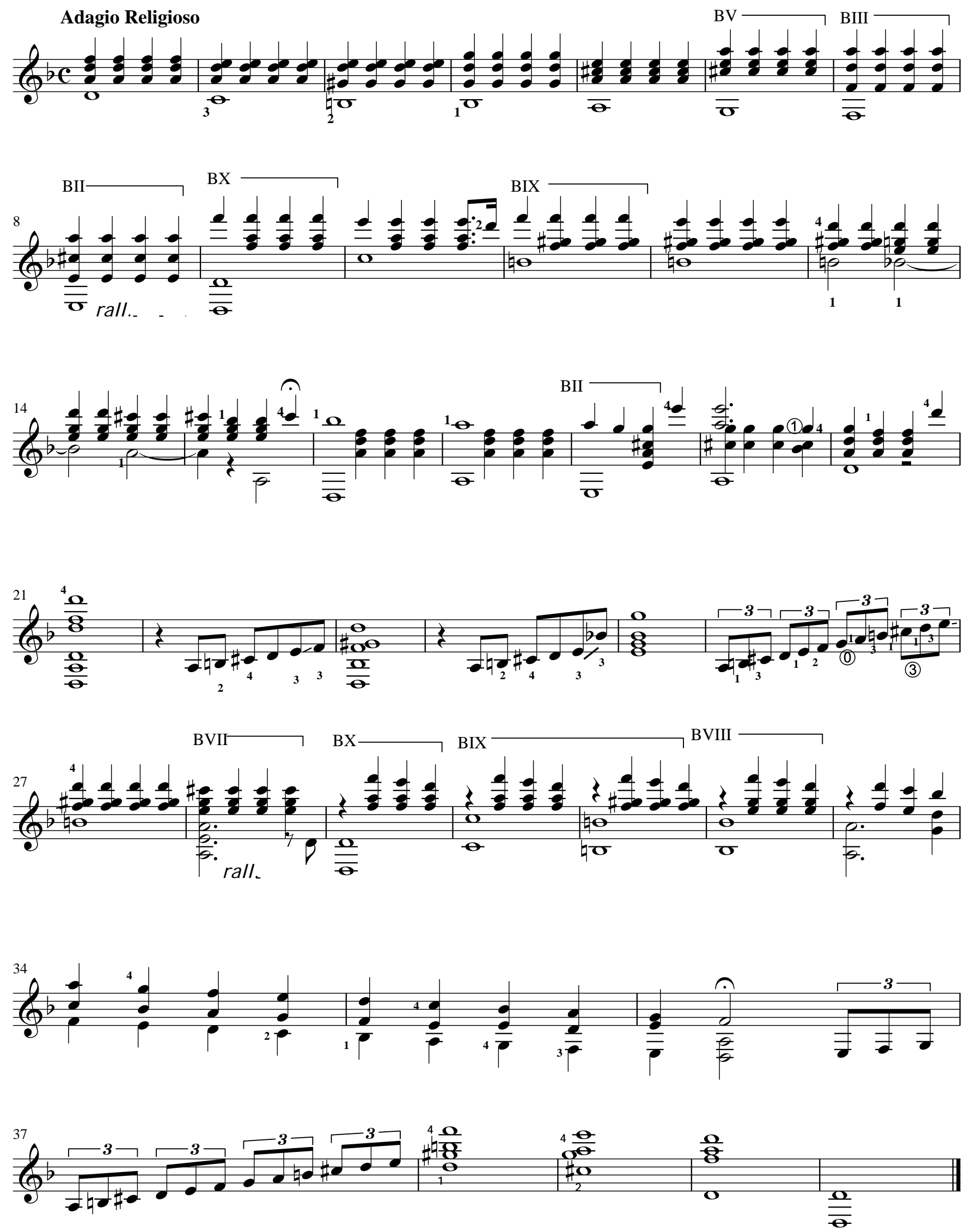
Nicanor Teixeira
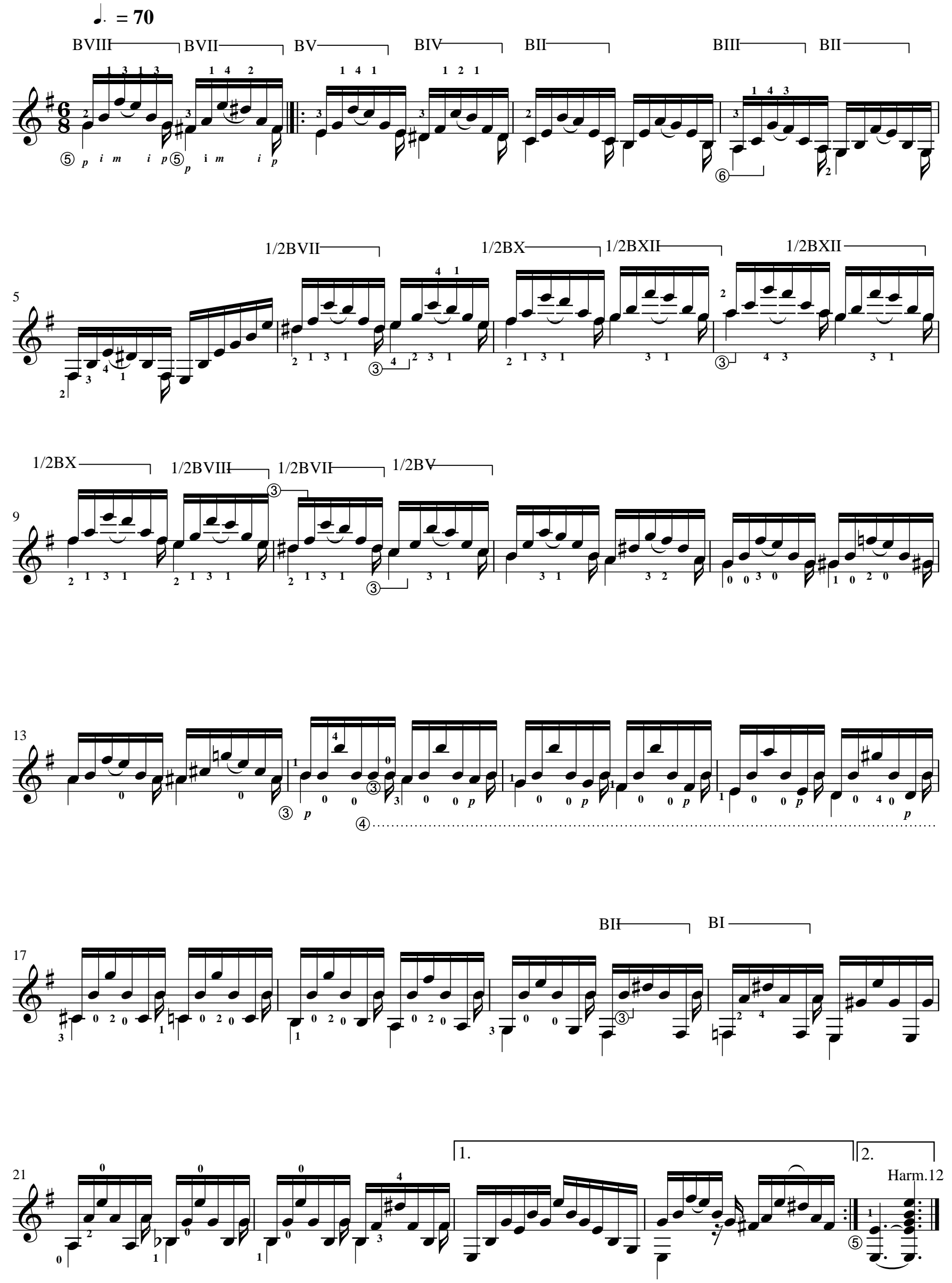

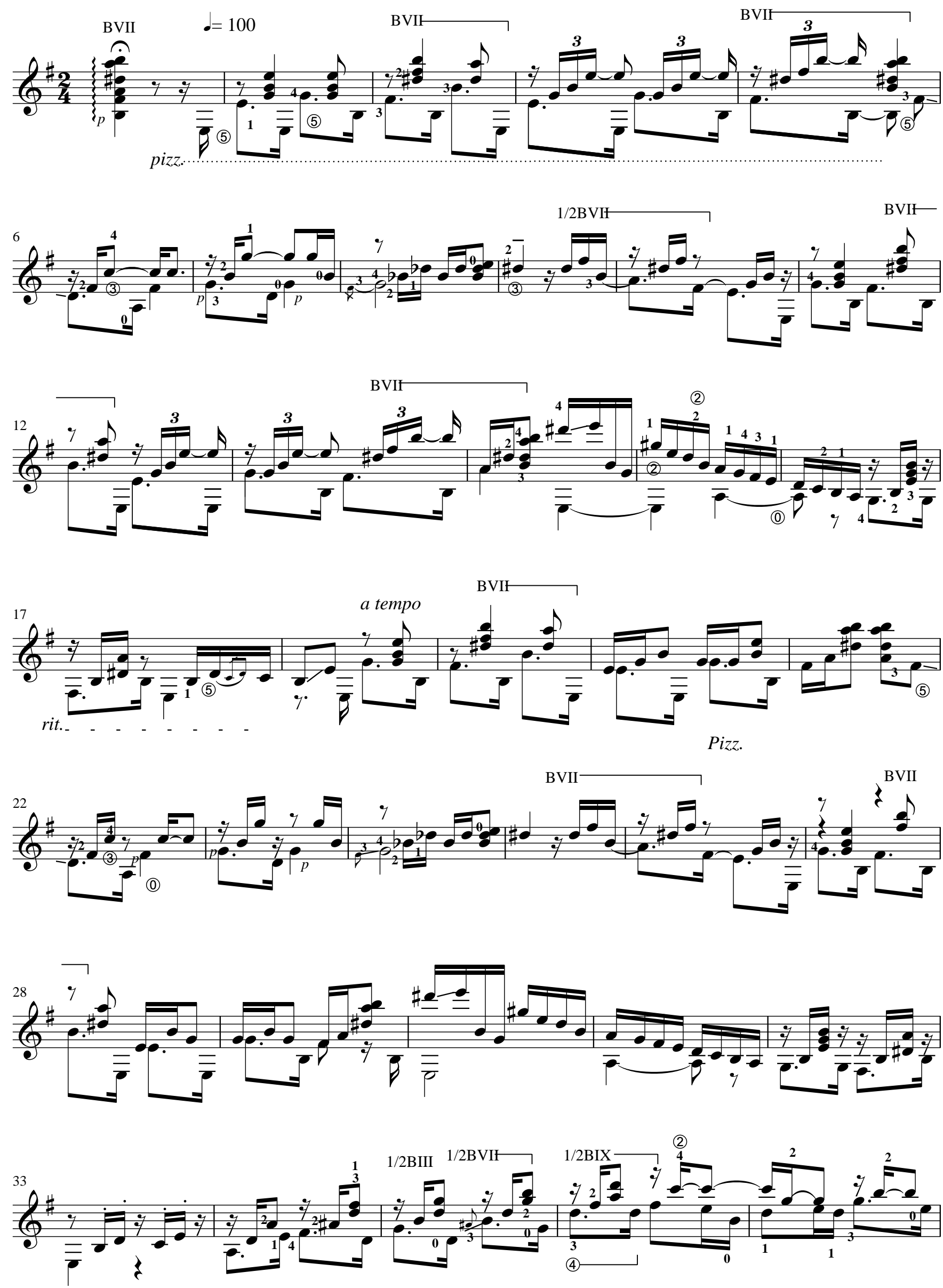

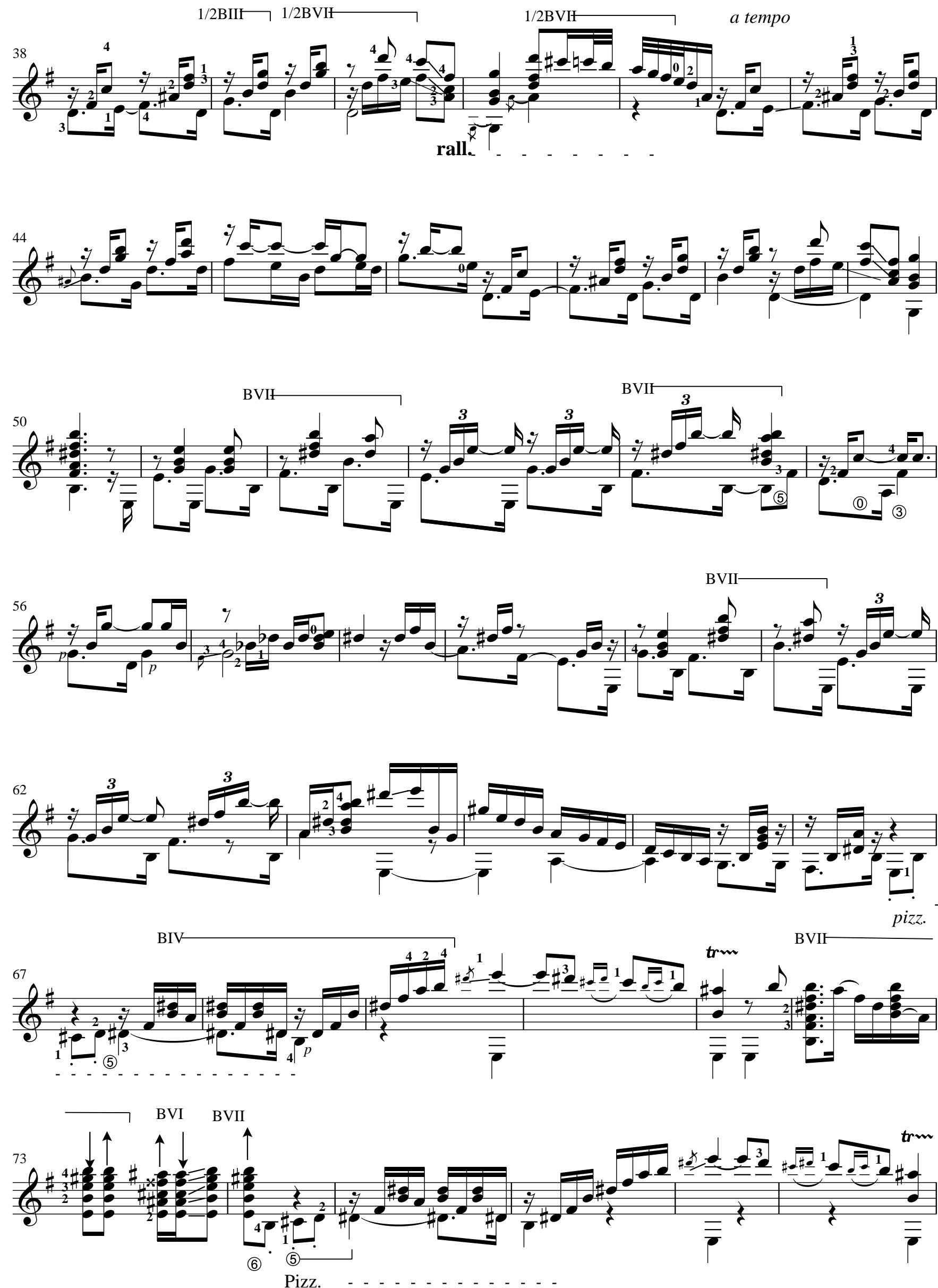

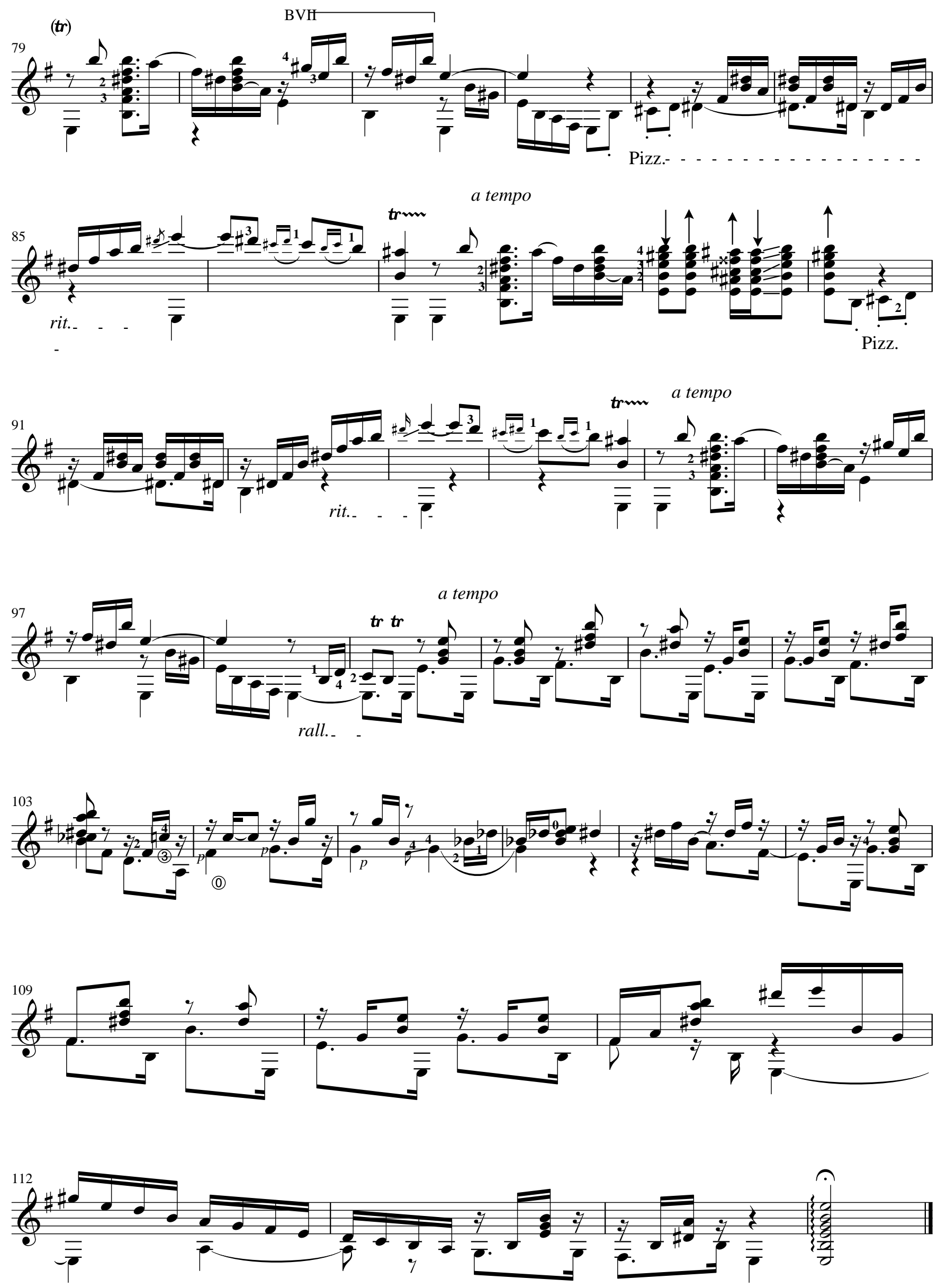

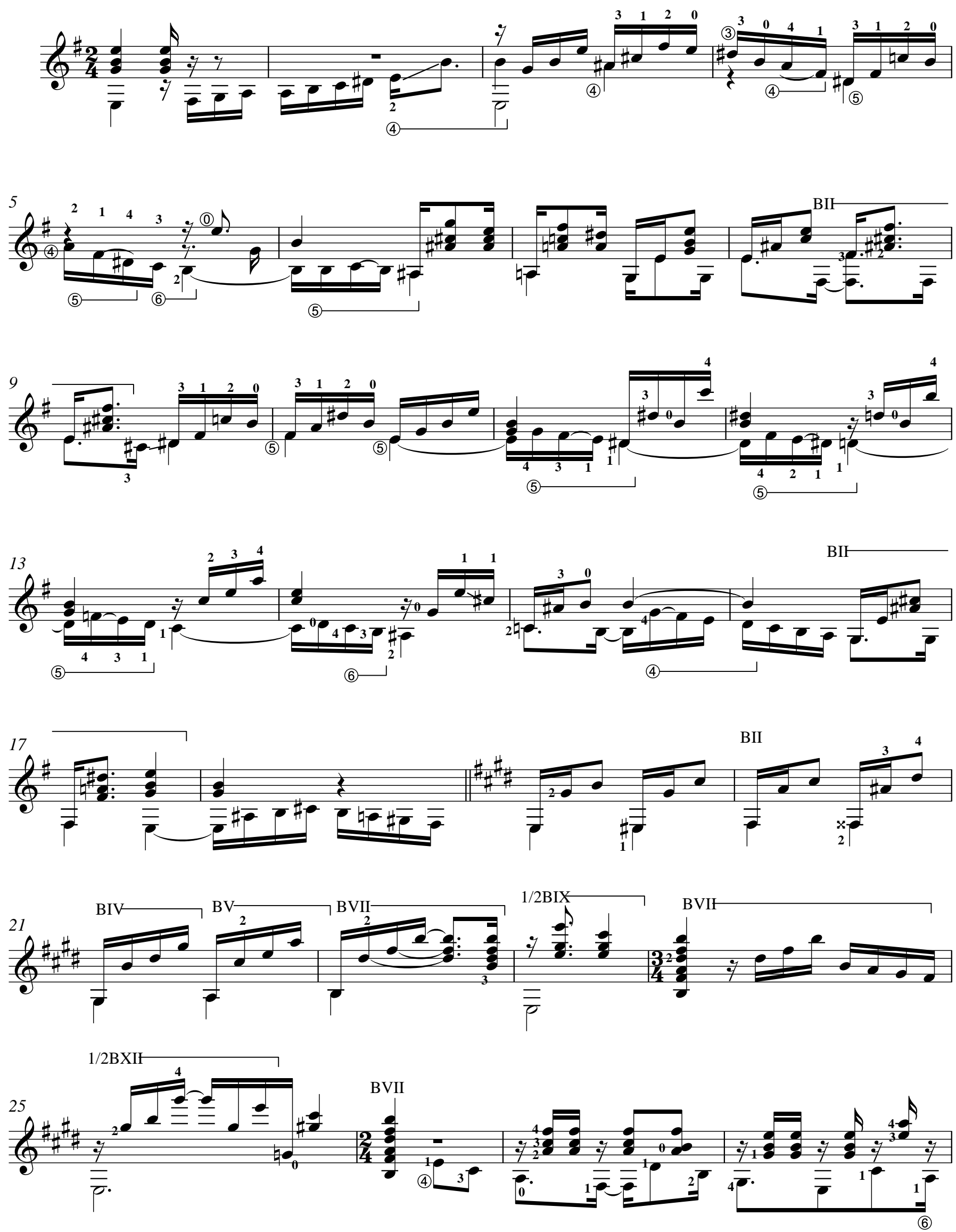

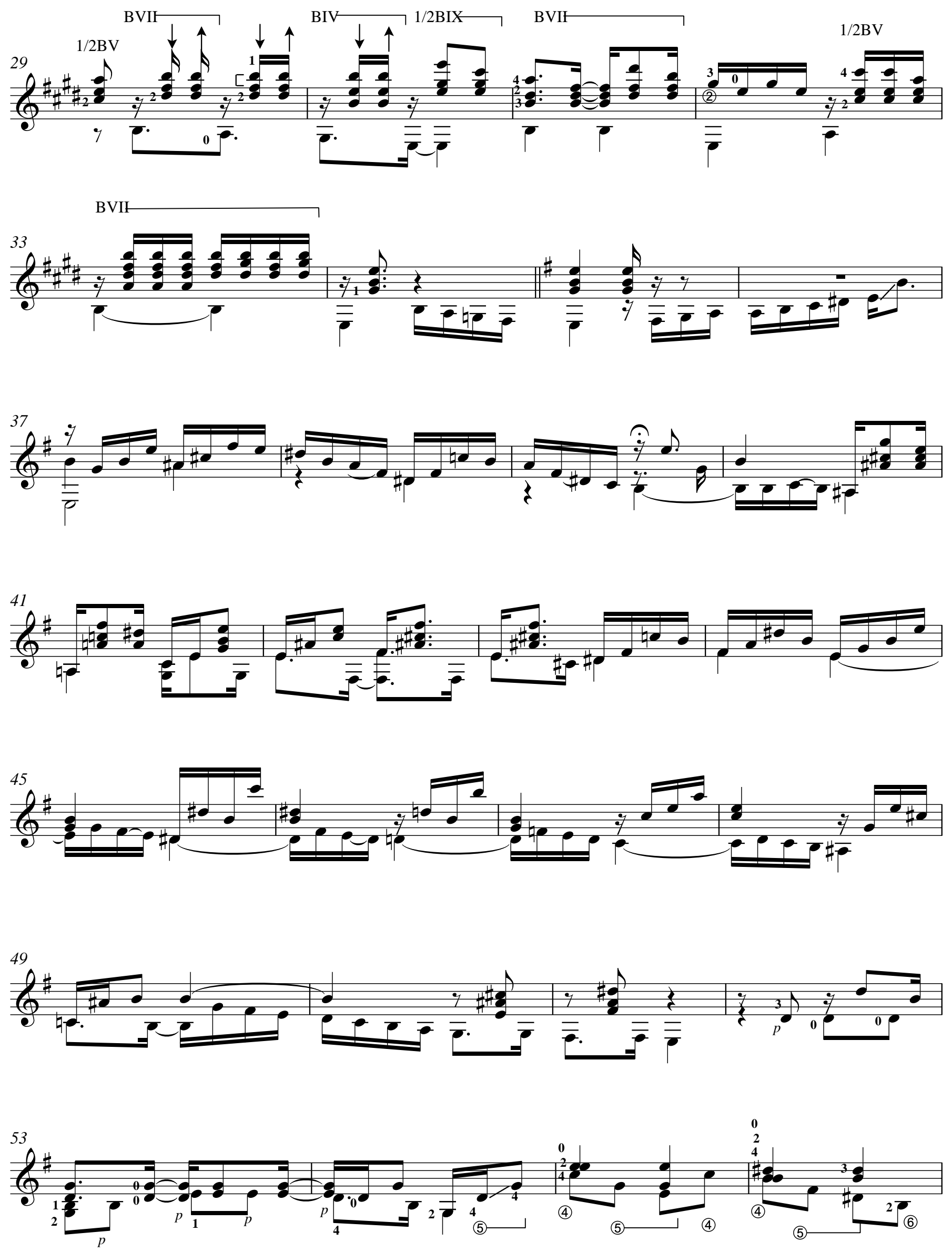

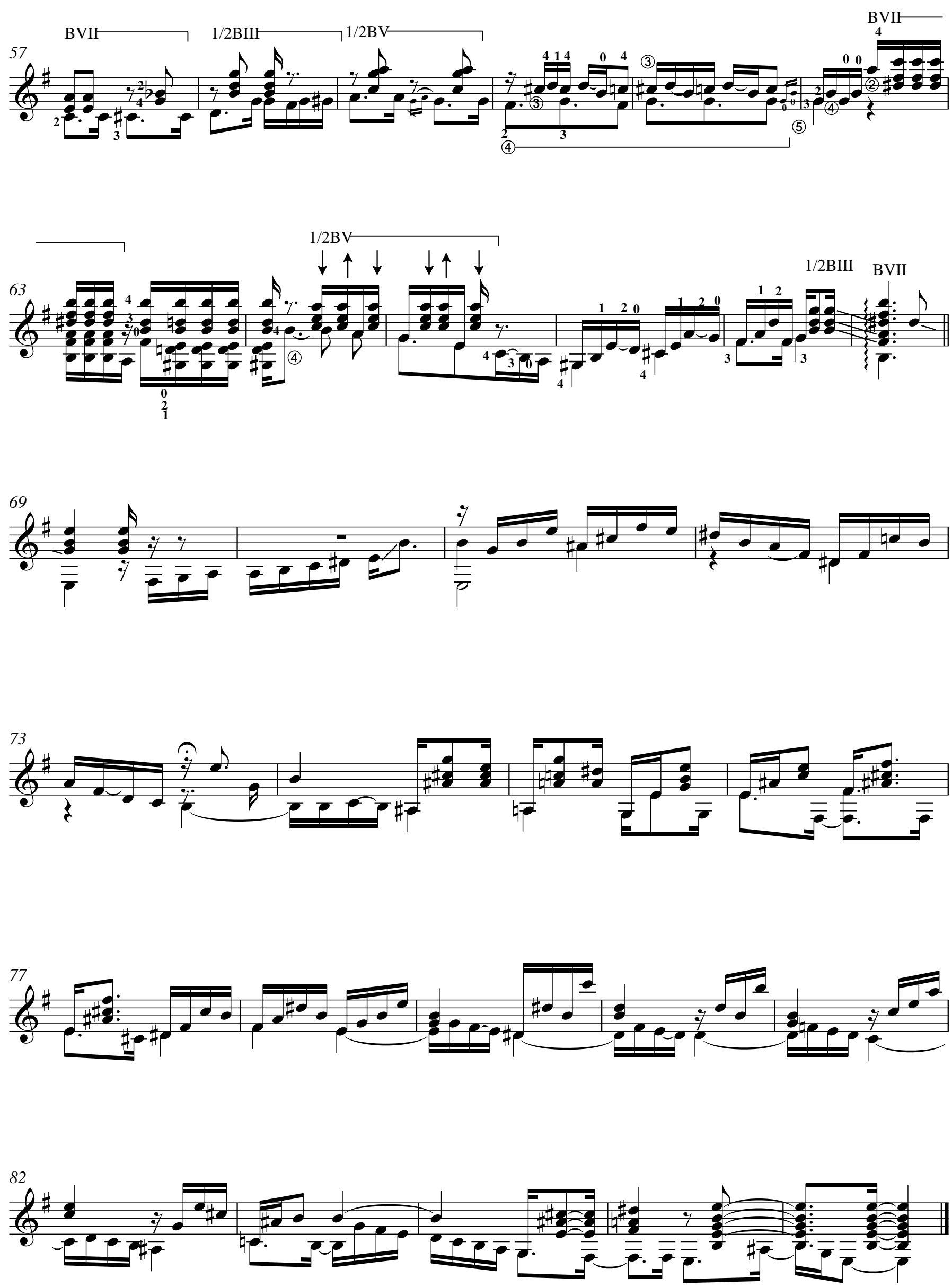
(6) em D

(5) em G

(1) em D

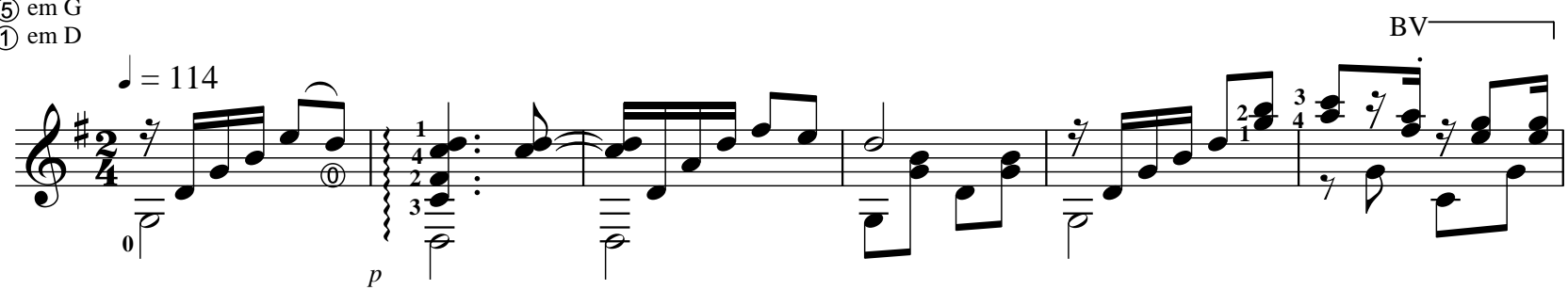

Violão

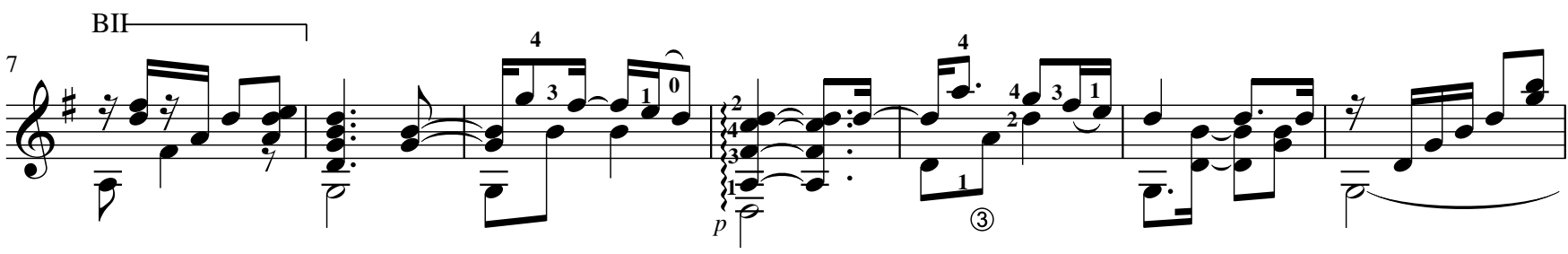

$1 / 2 \mathrm{BX}$ a tempo
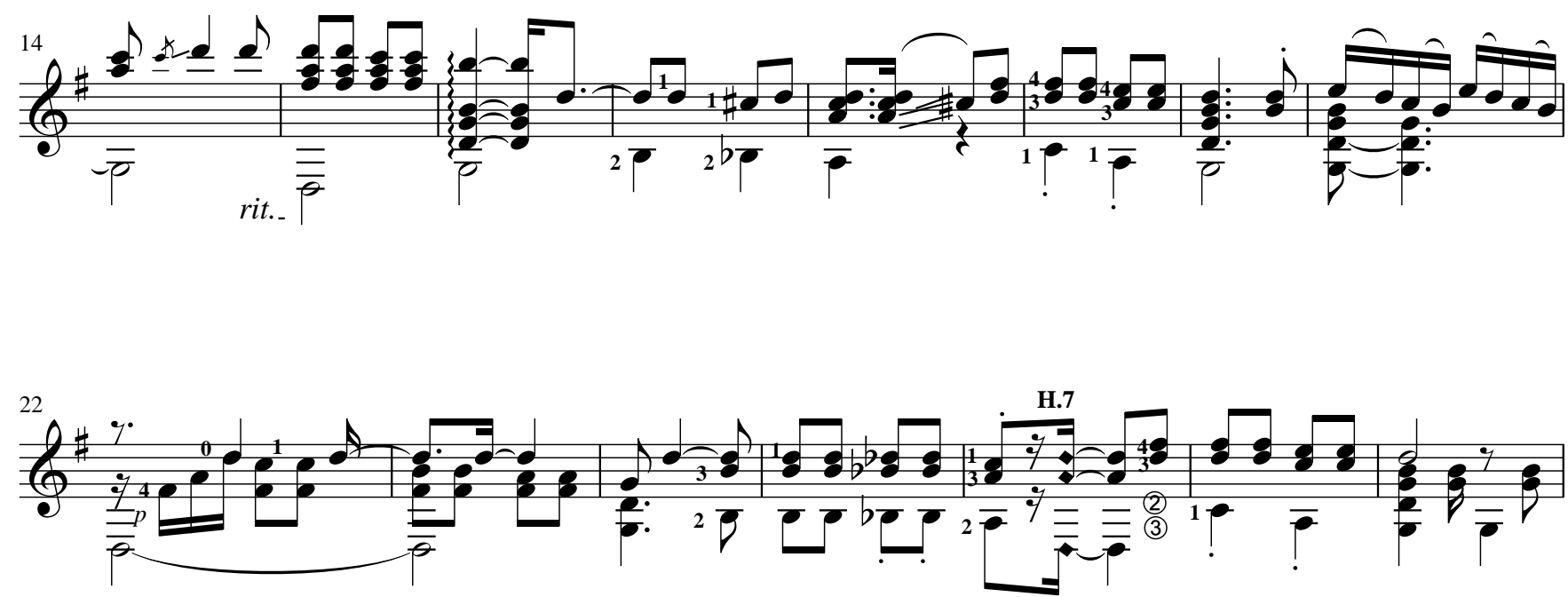

BV
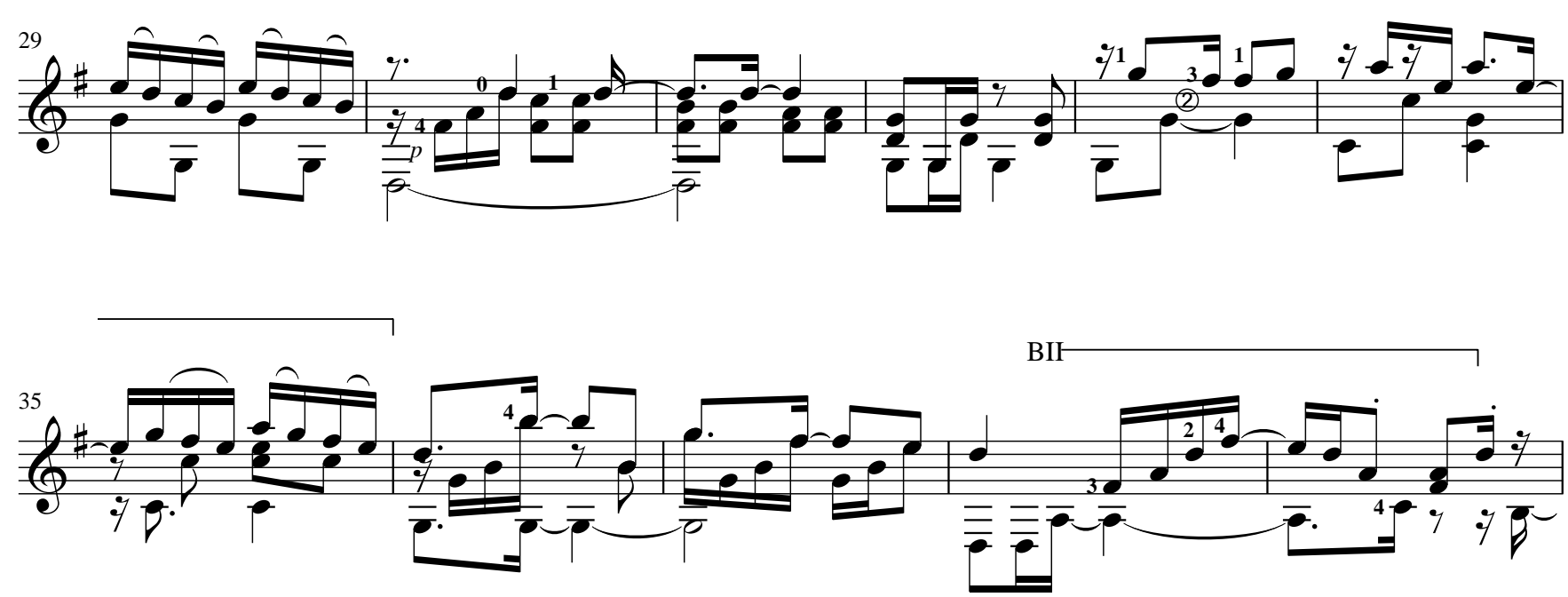

Partitura confeccionada para a dissertação de mestrado: Othon Salleiro: Um Barrios brasileiro? 

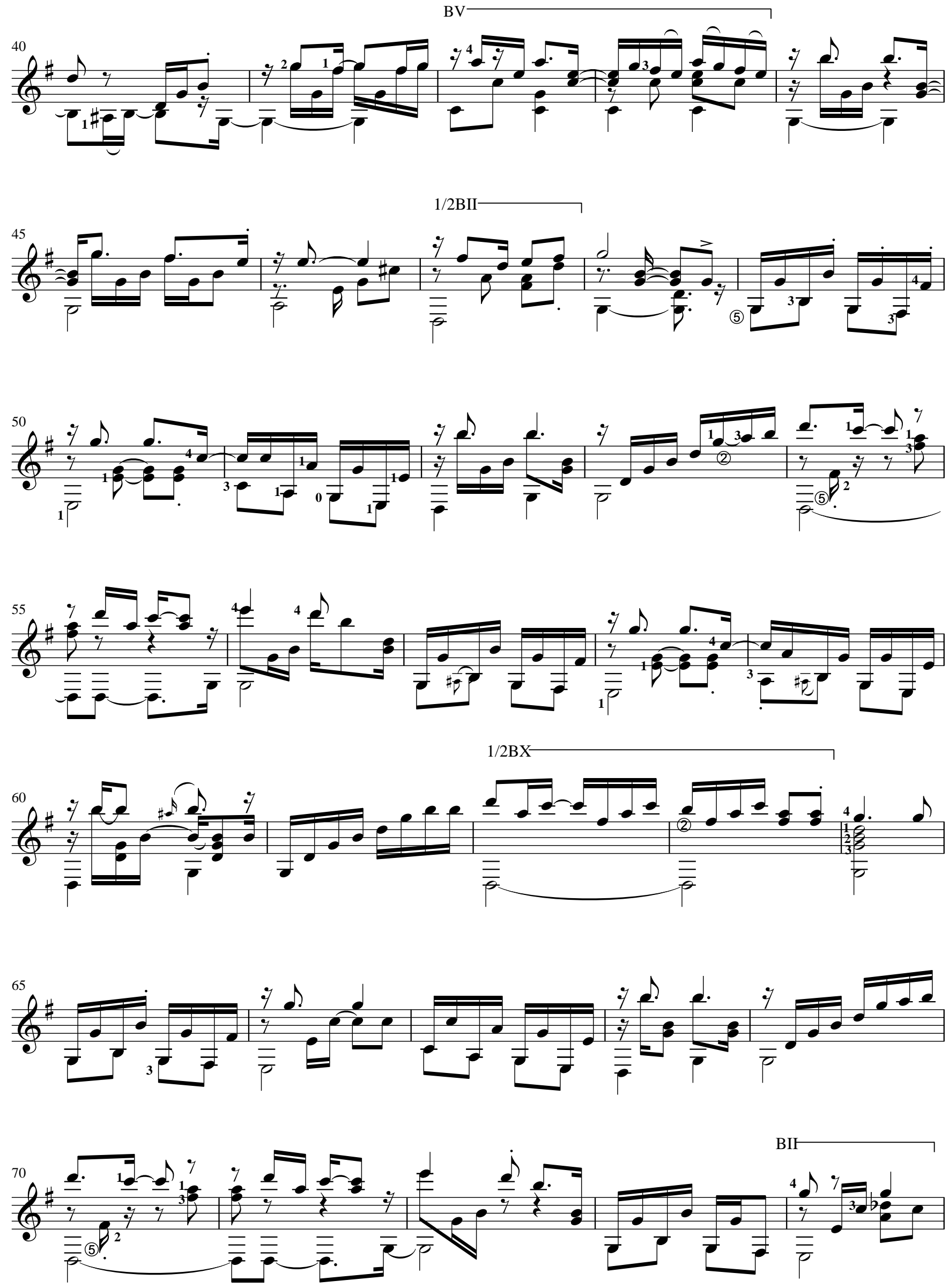

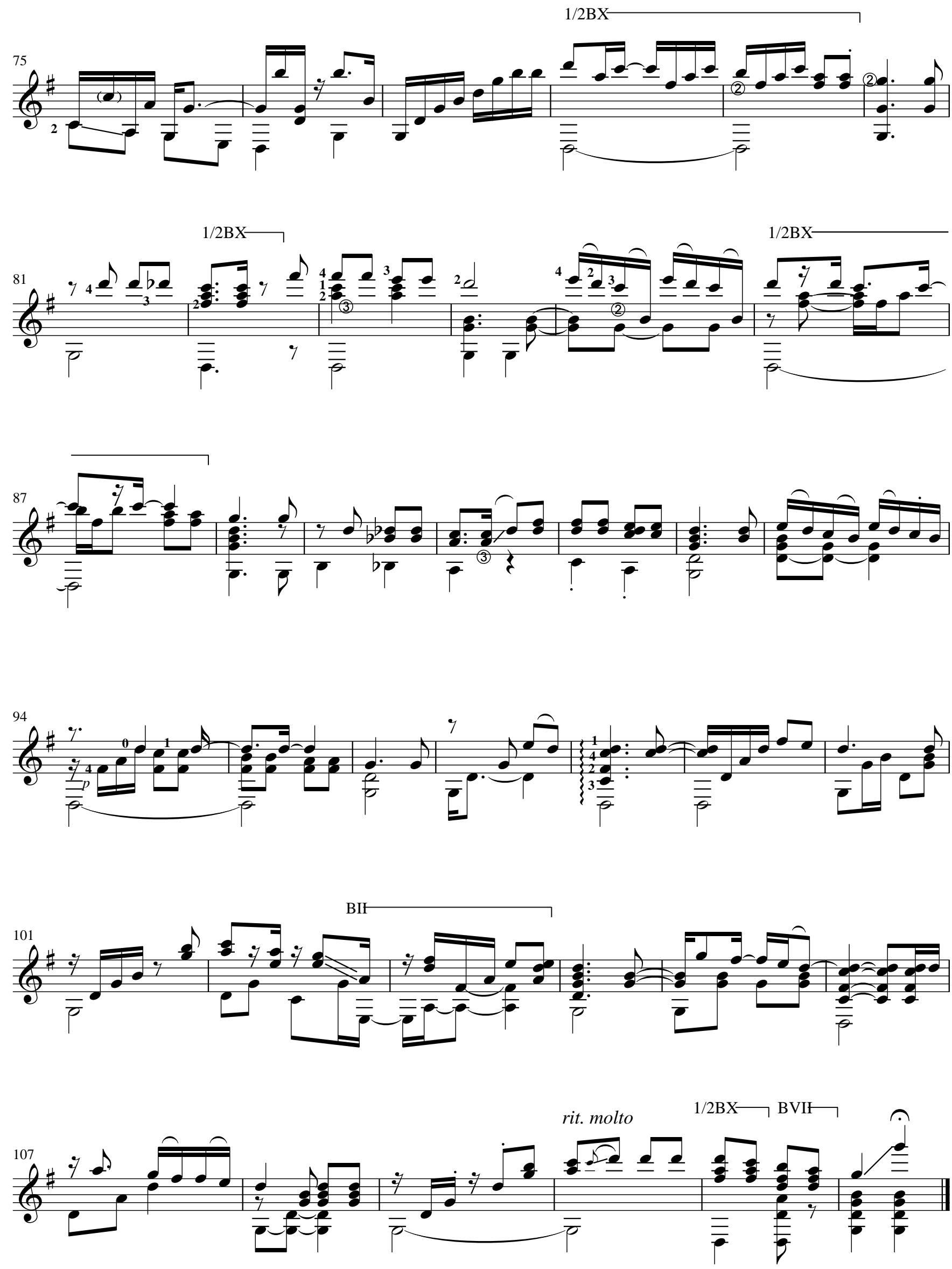
Partitura digitalizada e revisada a partir de manuscrito do compositor Flavia Prando
Sonho de Cavaquinho

\author{
Chôro
}

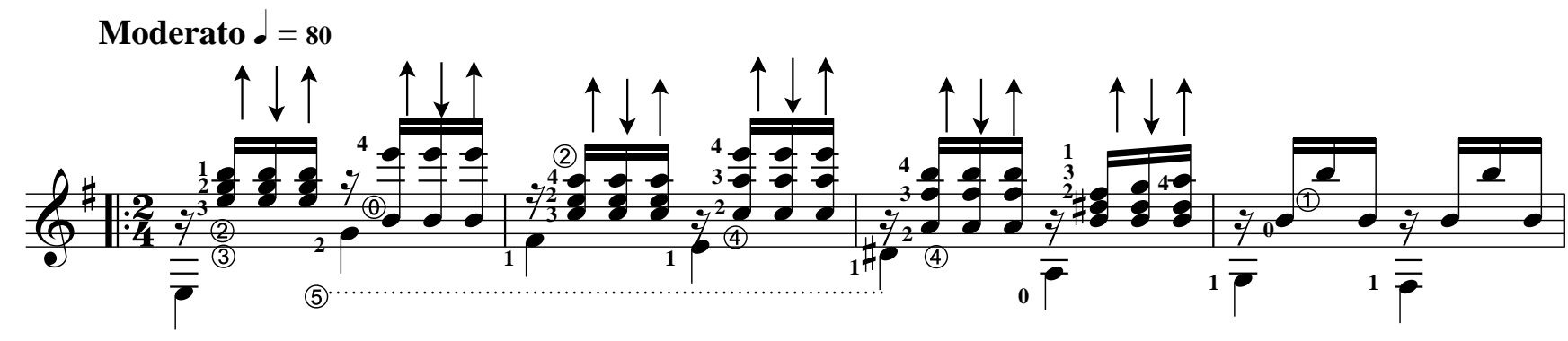

BIX
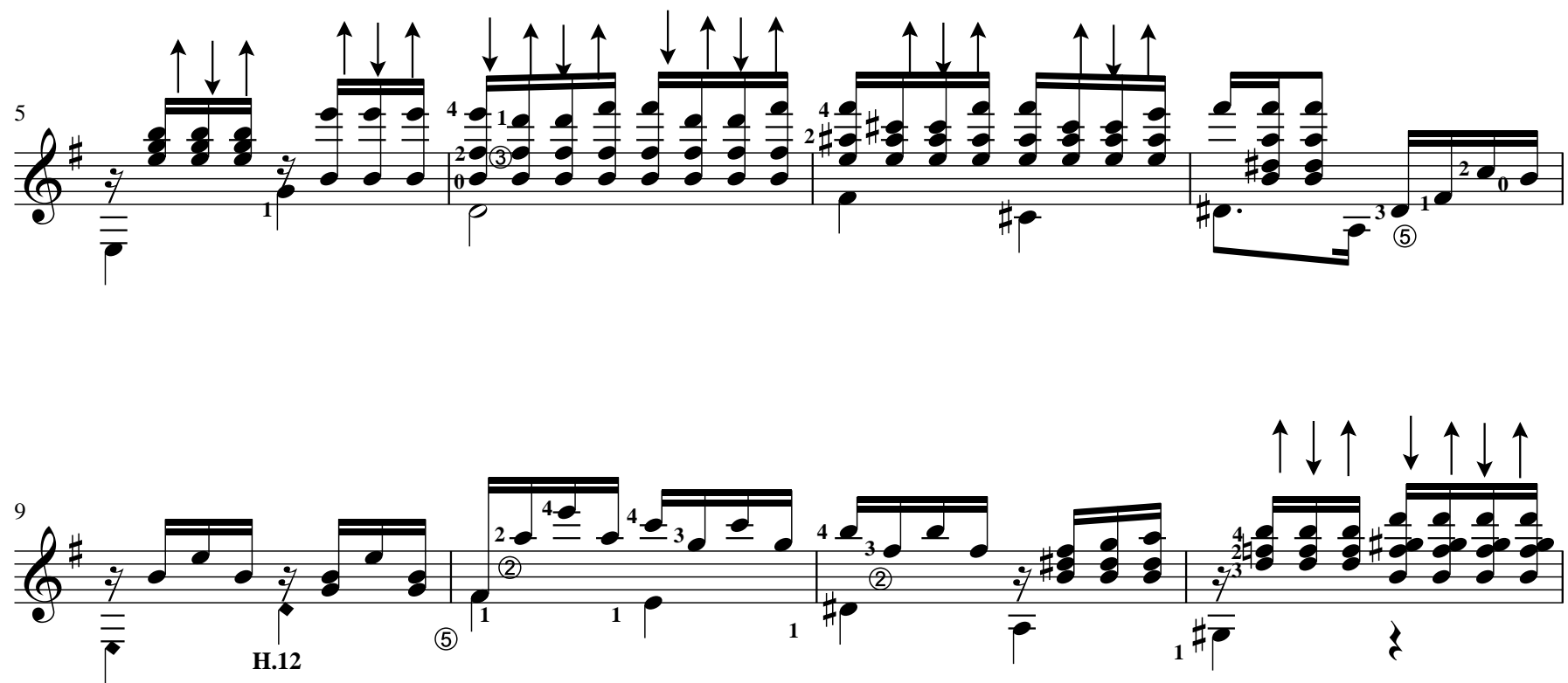

H.12
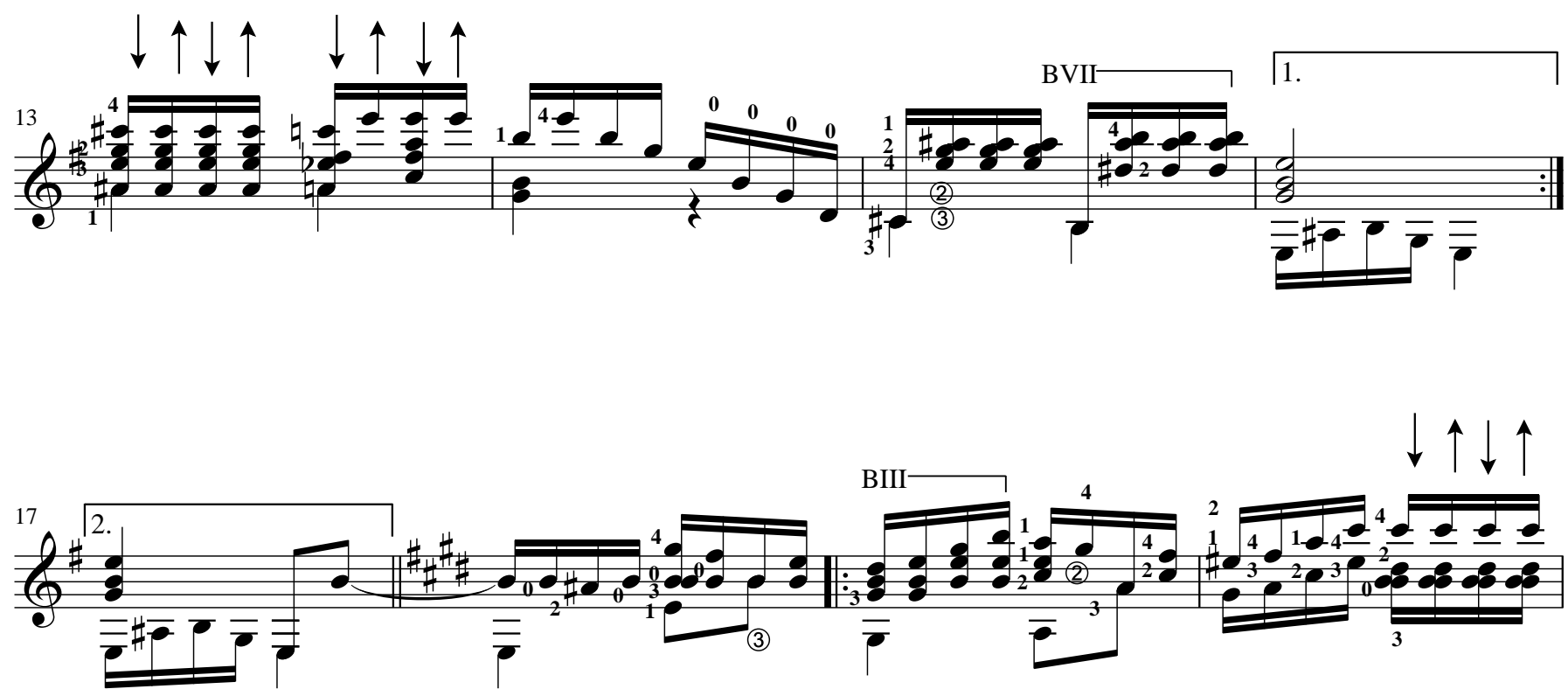

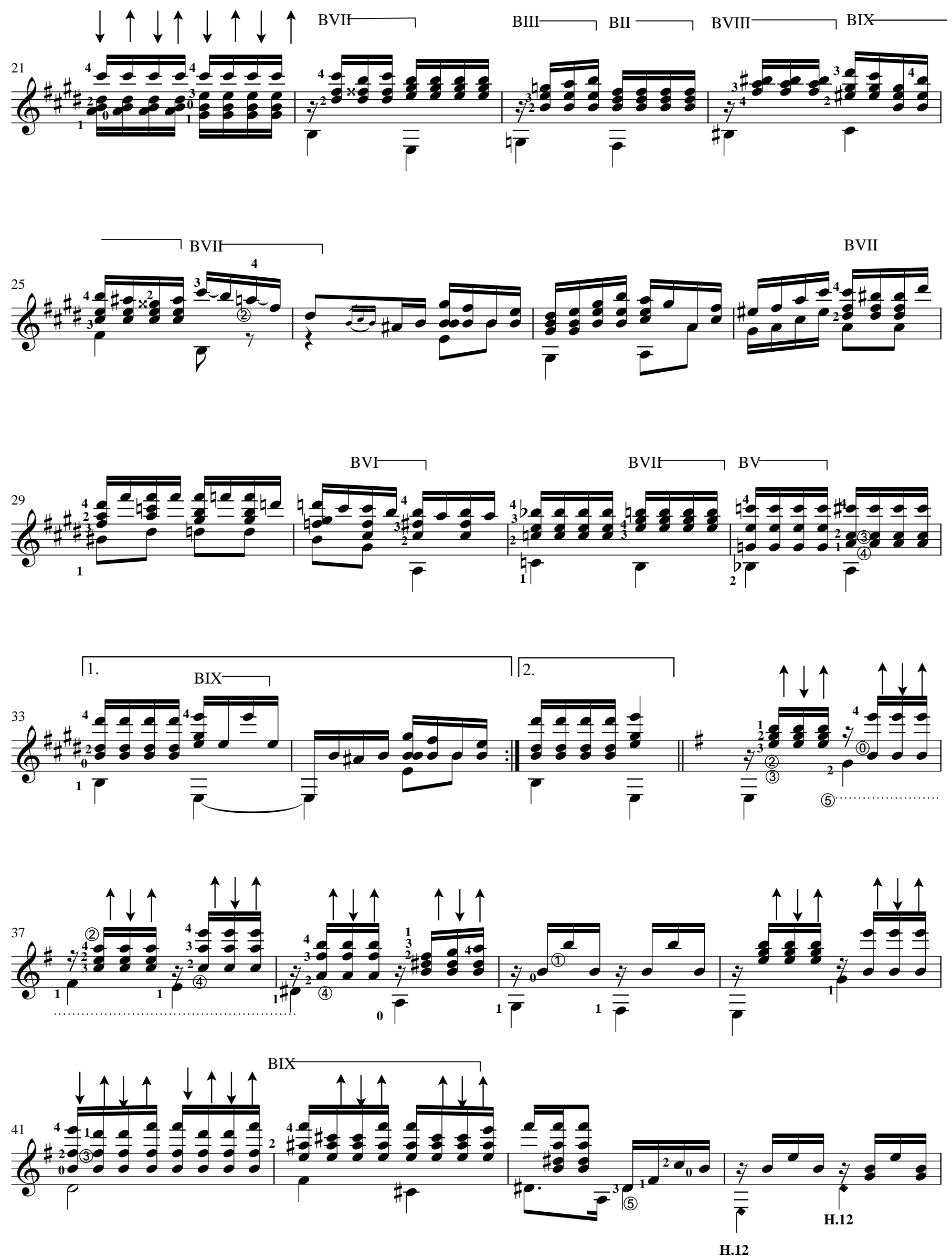

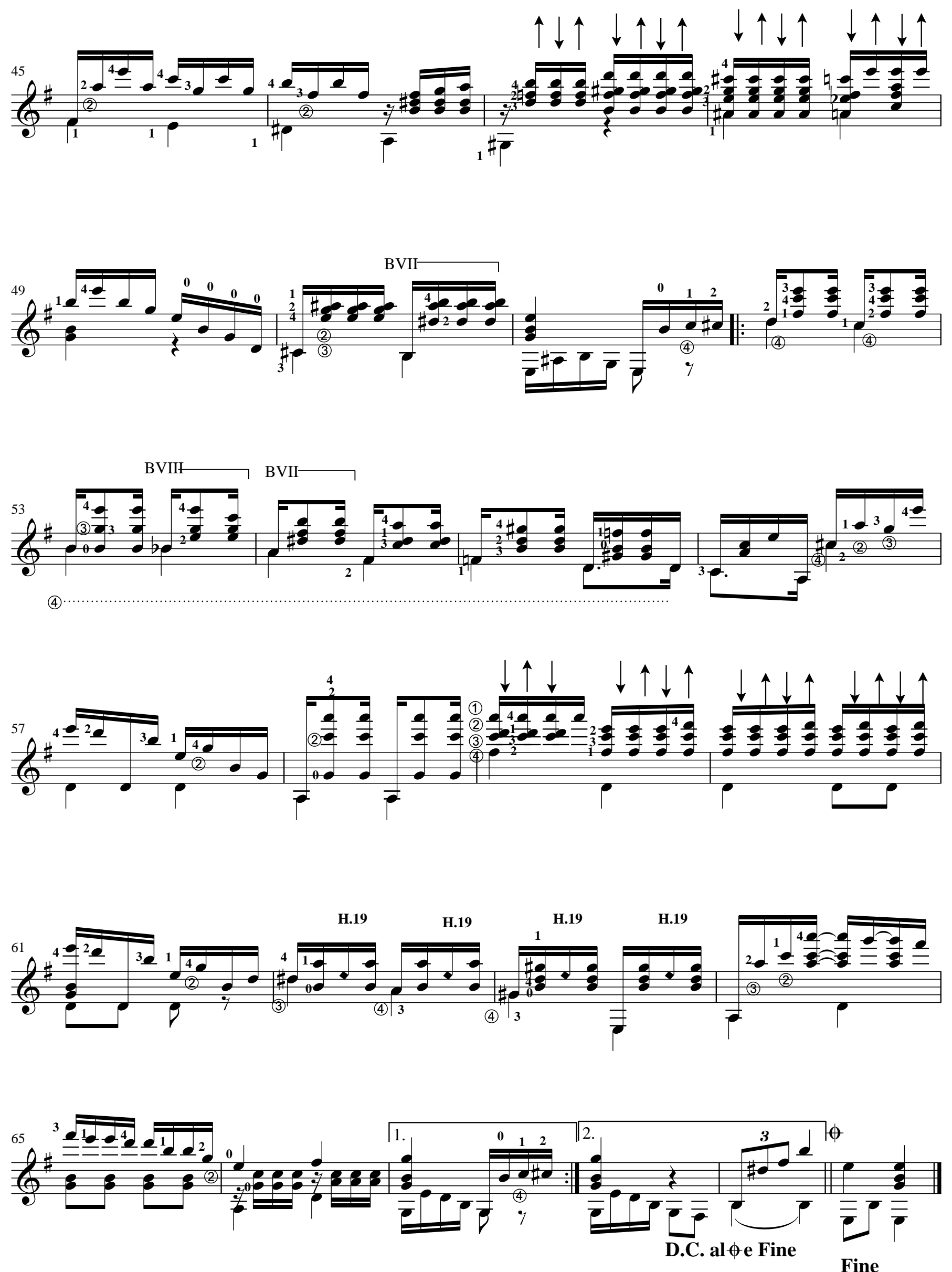
224

Extraída e digitada

Ternura

Othon Salleiro

a partir da gravação

do compositor

(1) em D
(2) em A
(3) em F\#
(6) em D $\quad .=8 \boldsymbol{0}$

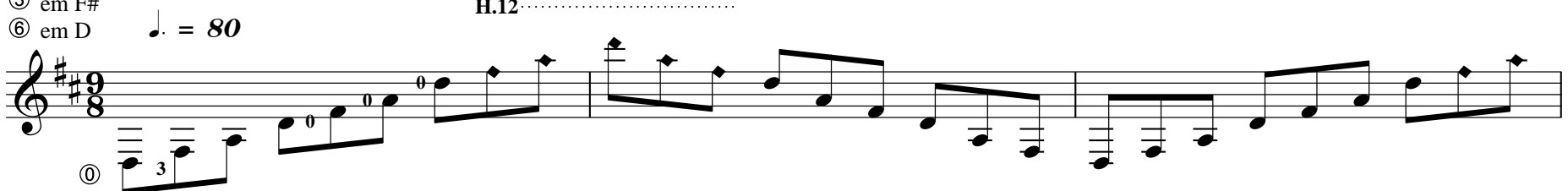

metalico
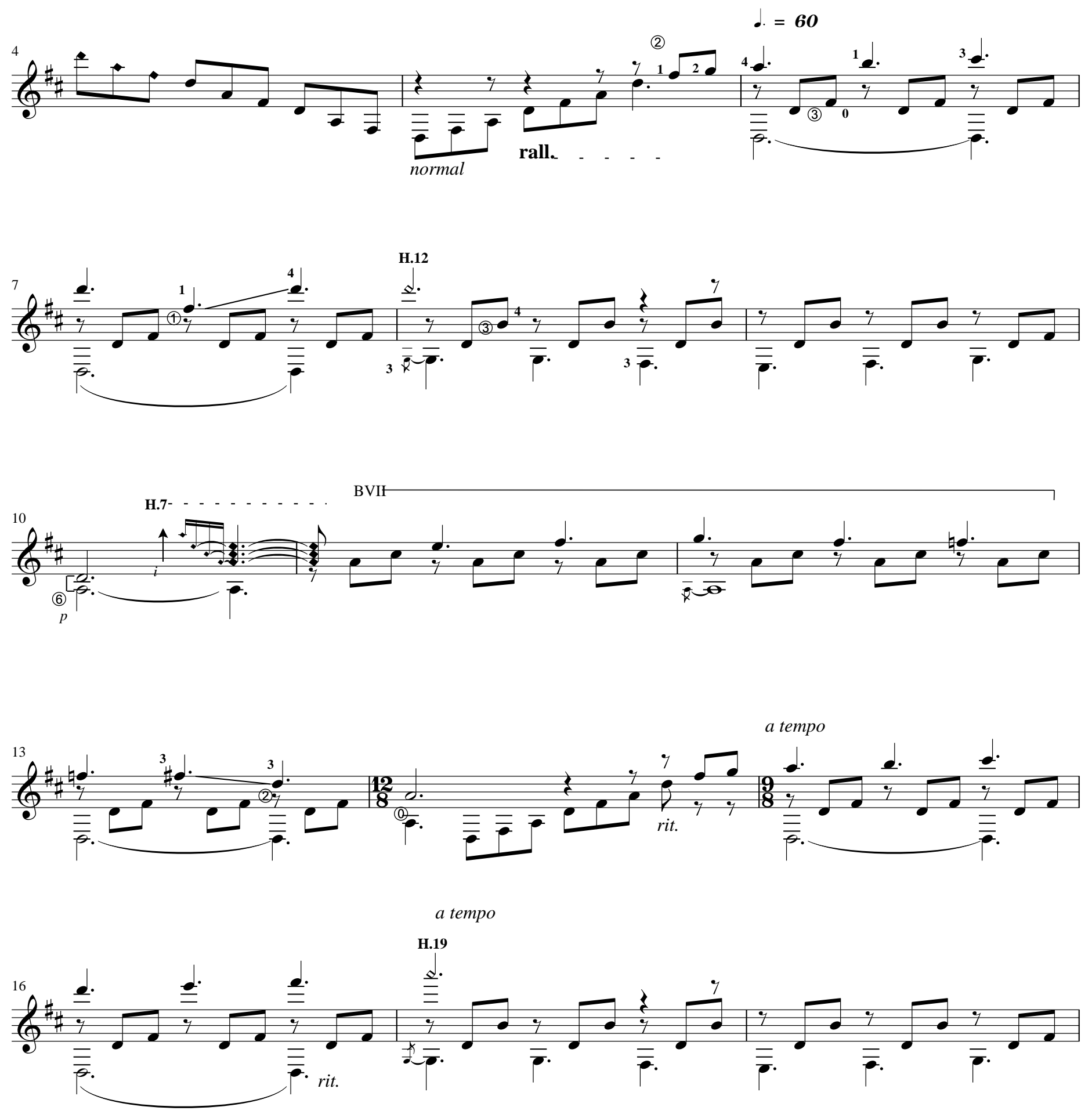

Partitura confeccionada para a dissertação de mestrado: Othon Salleiro: Um Barrios brasileiro?

Flavia Prando - ECA/USP - 2008 

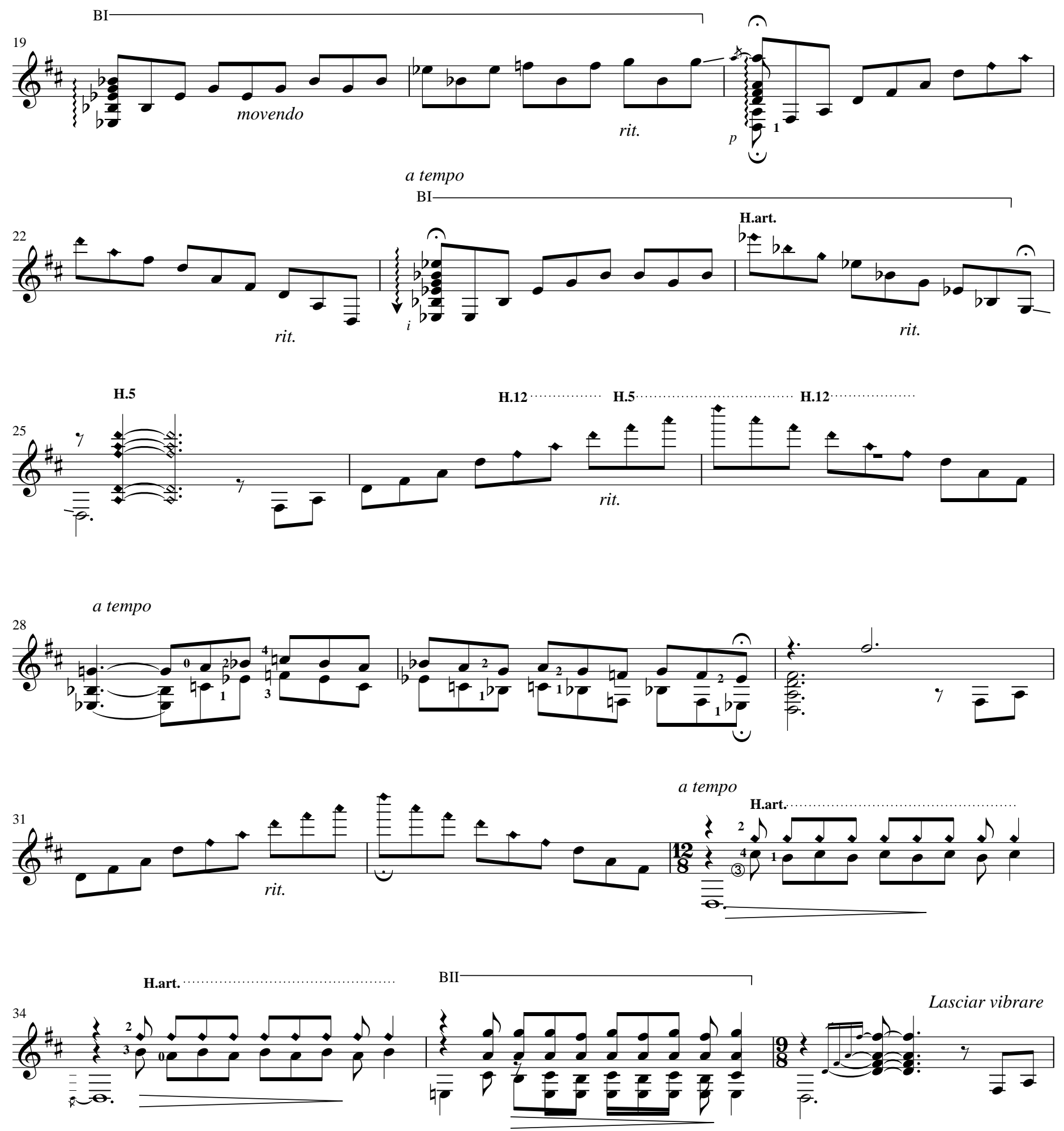

H.12

H.5

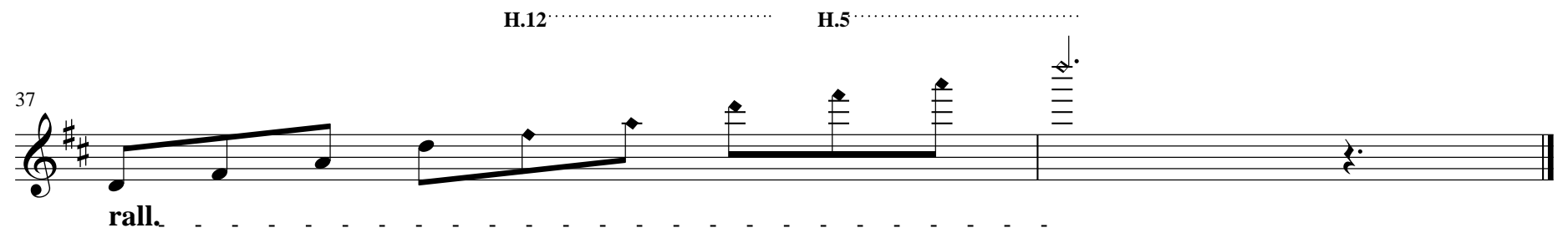




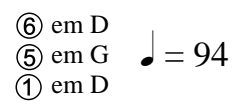

H.12
H.7 a tempo

BV

BIV

$\mathrm{BII}$

H.5

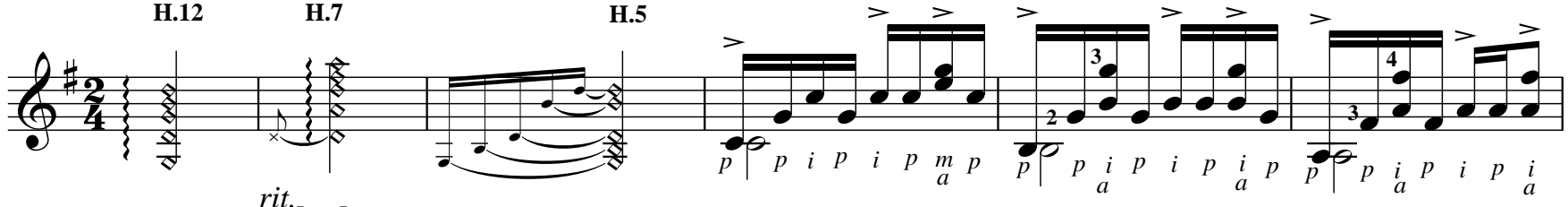

a tempo
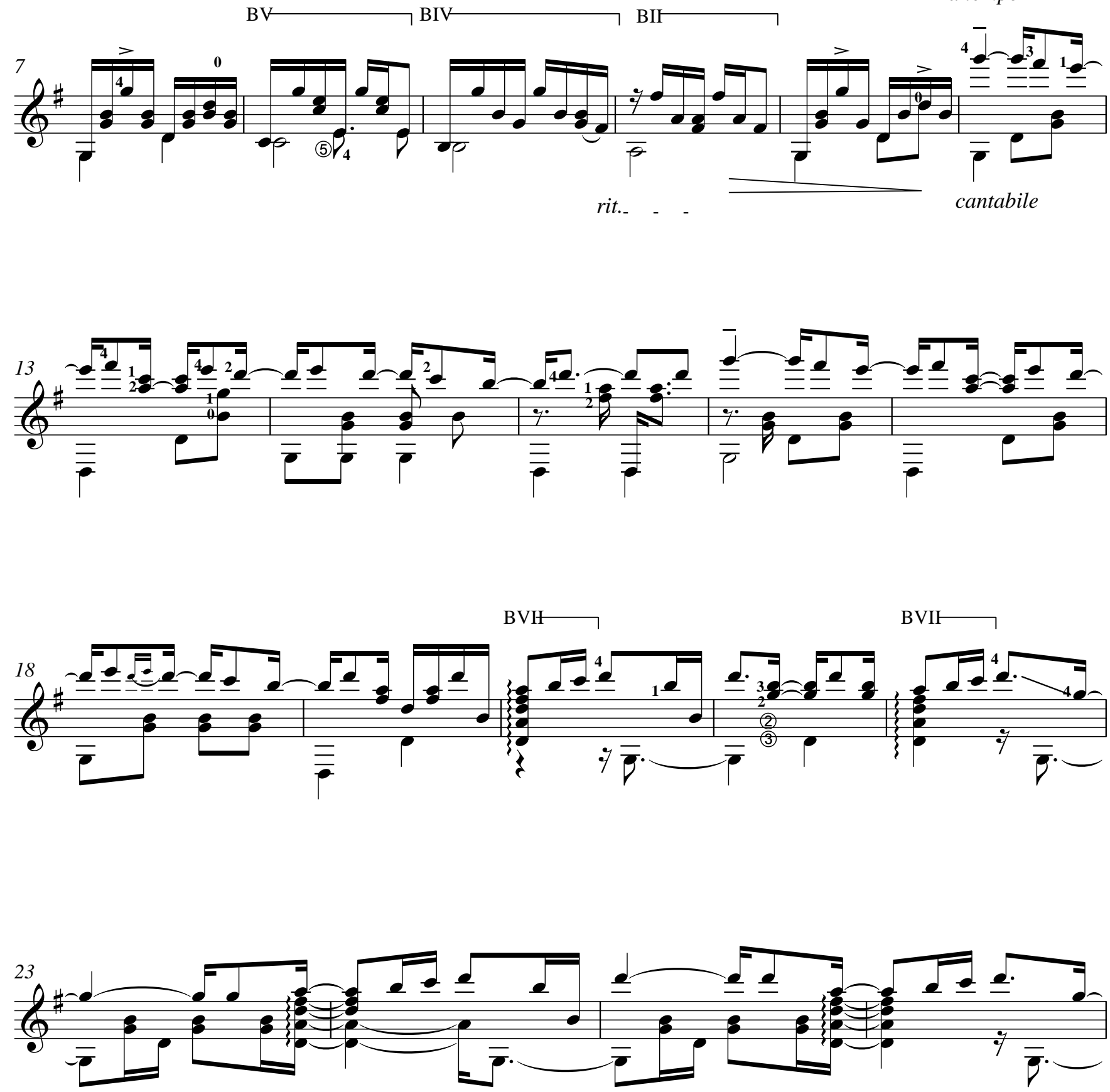

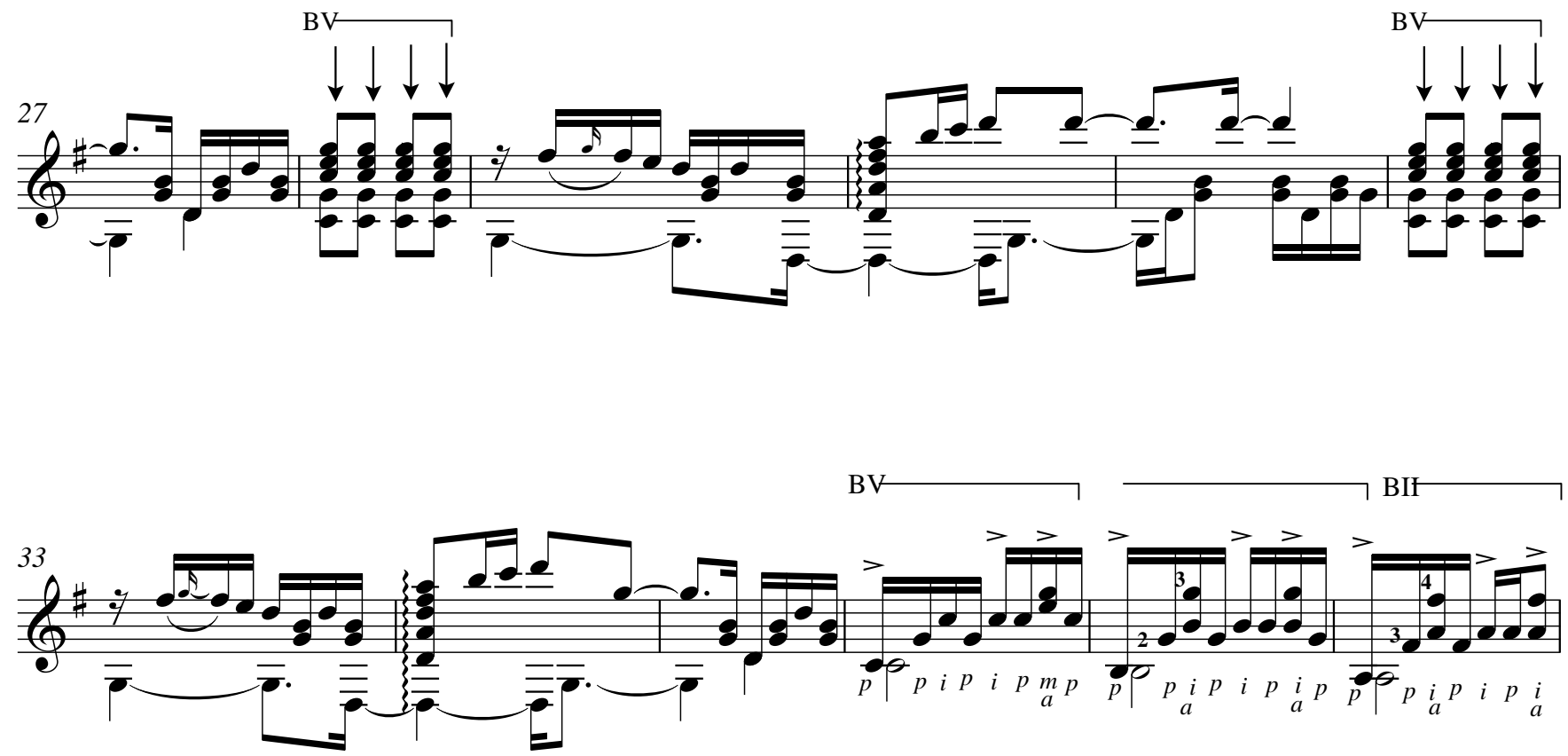

BV

$\mathrm{BI \longmapsto}$

a tempo

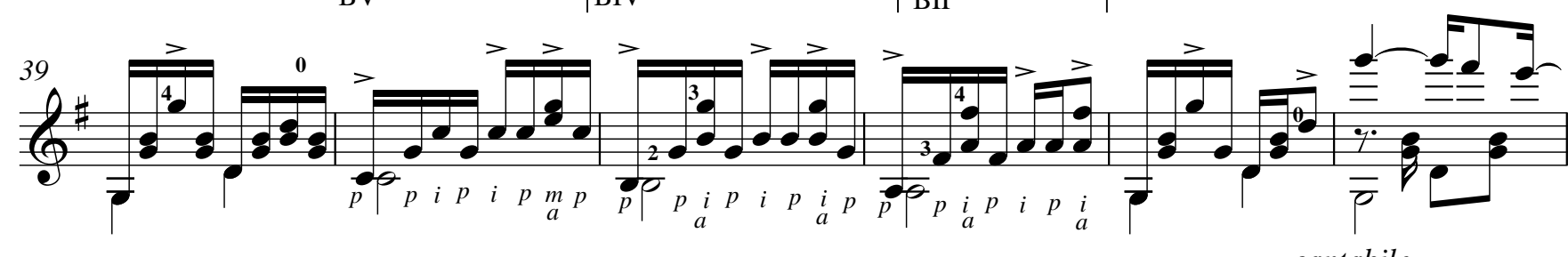

rit._ _

cantabile

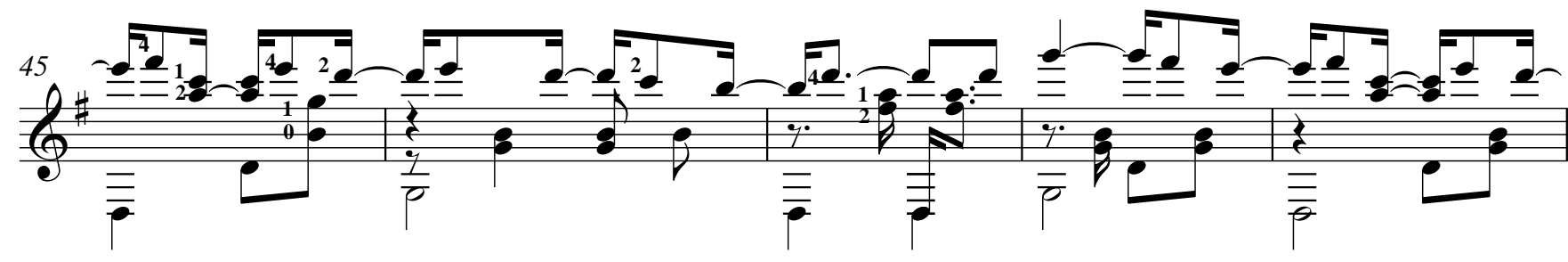

BVIঙ BVIঙ

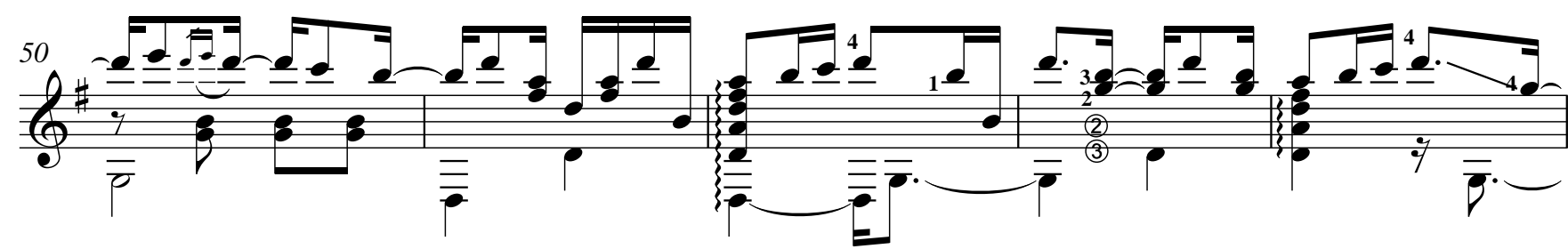



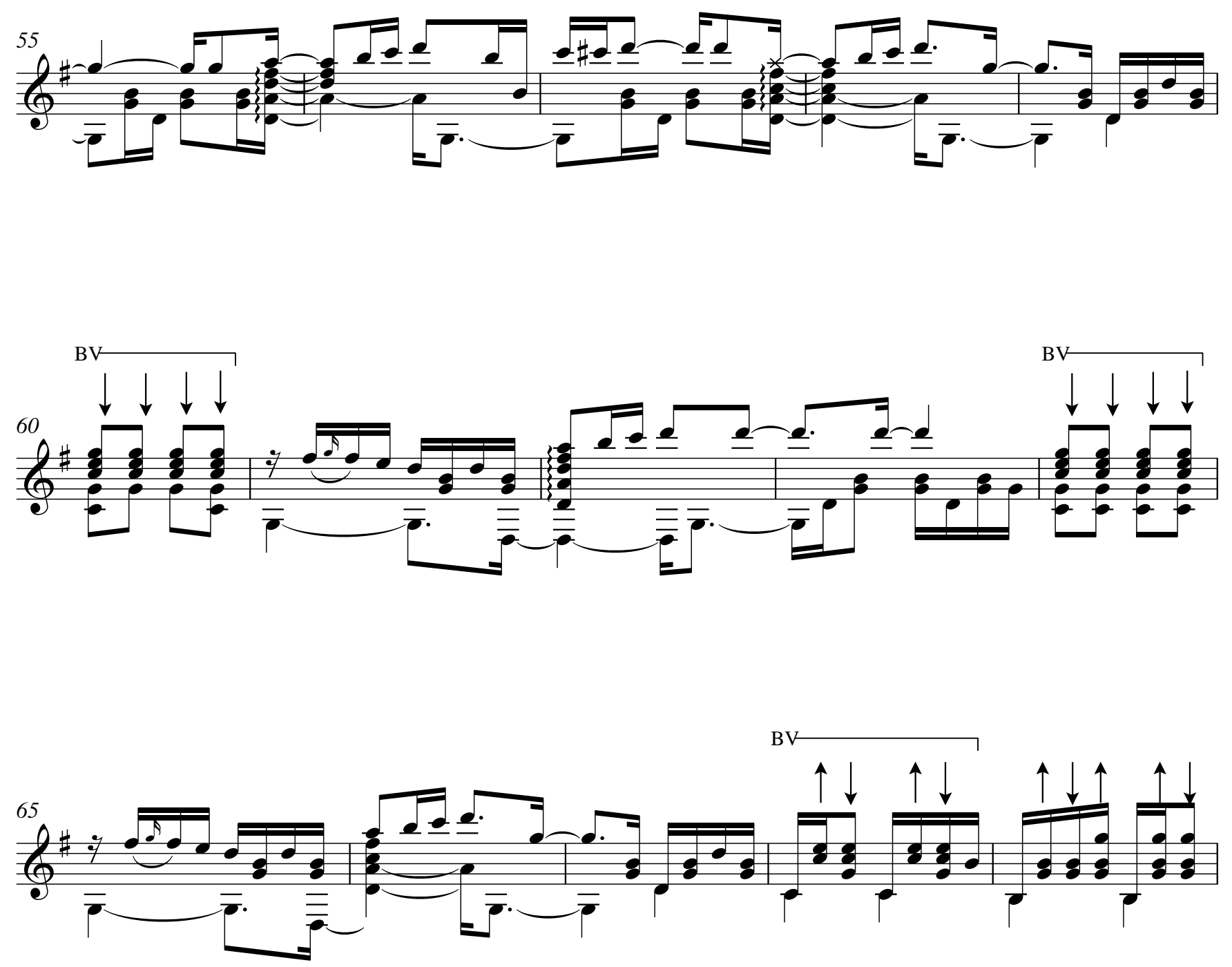

TAMBORA-
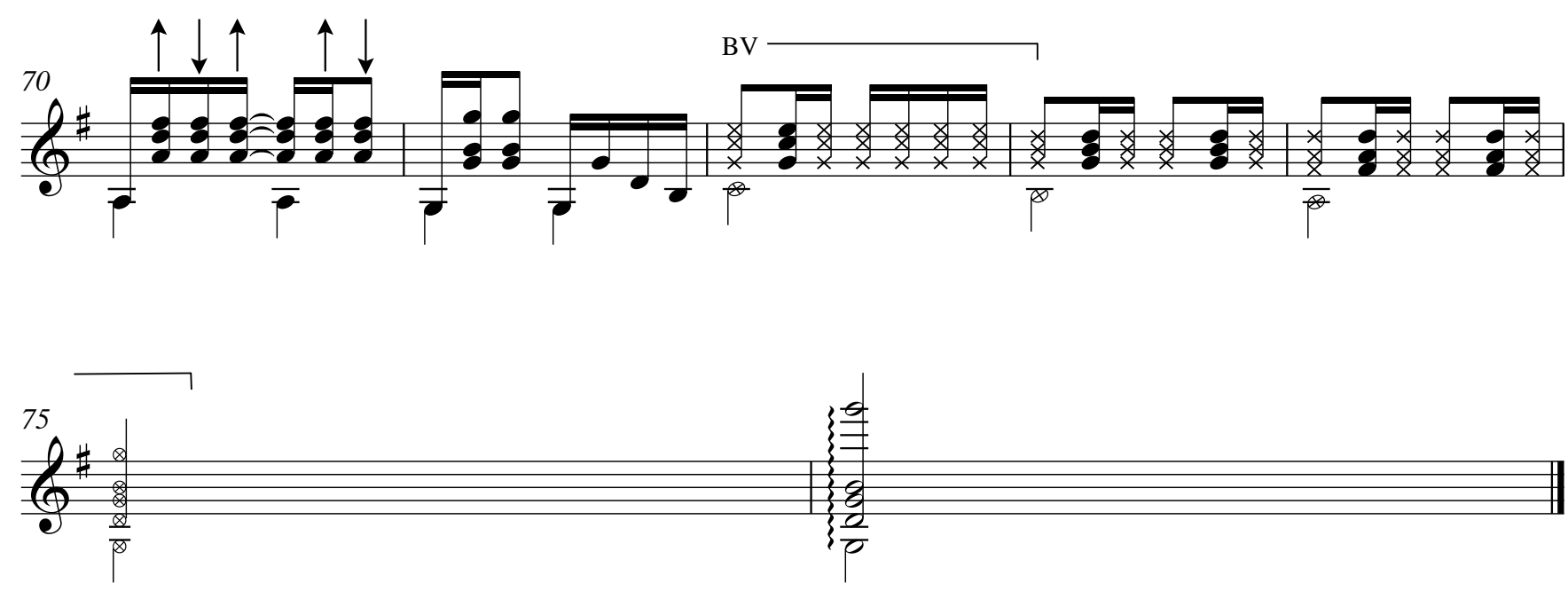


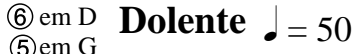

(1) em D
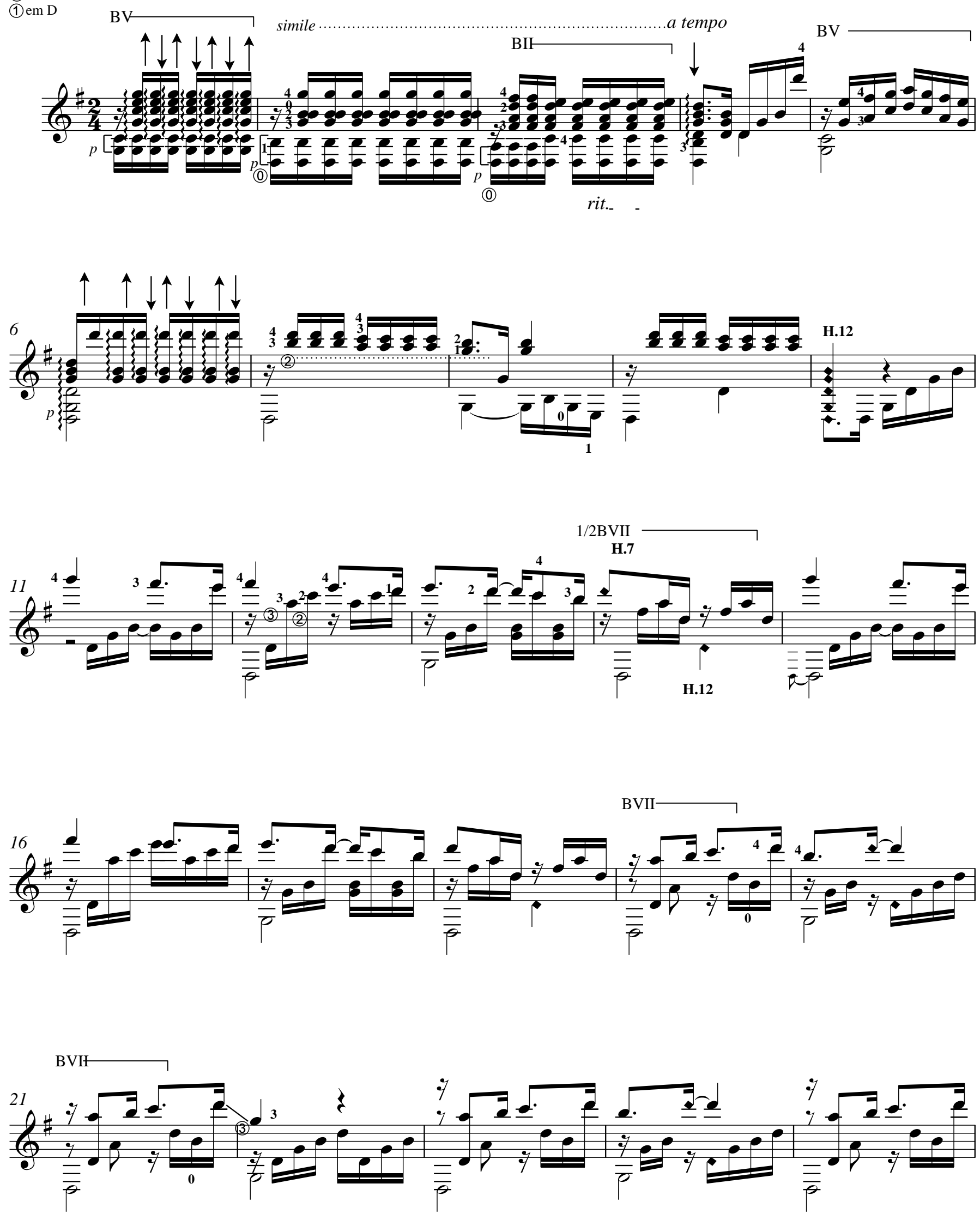

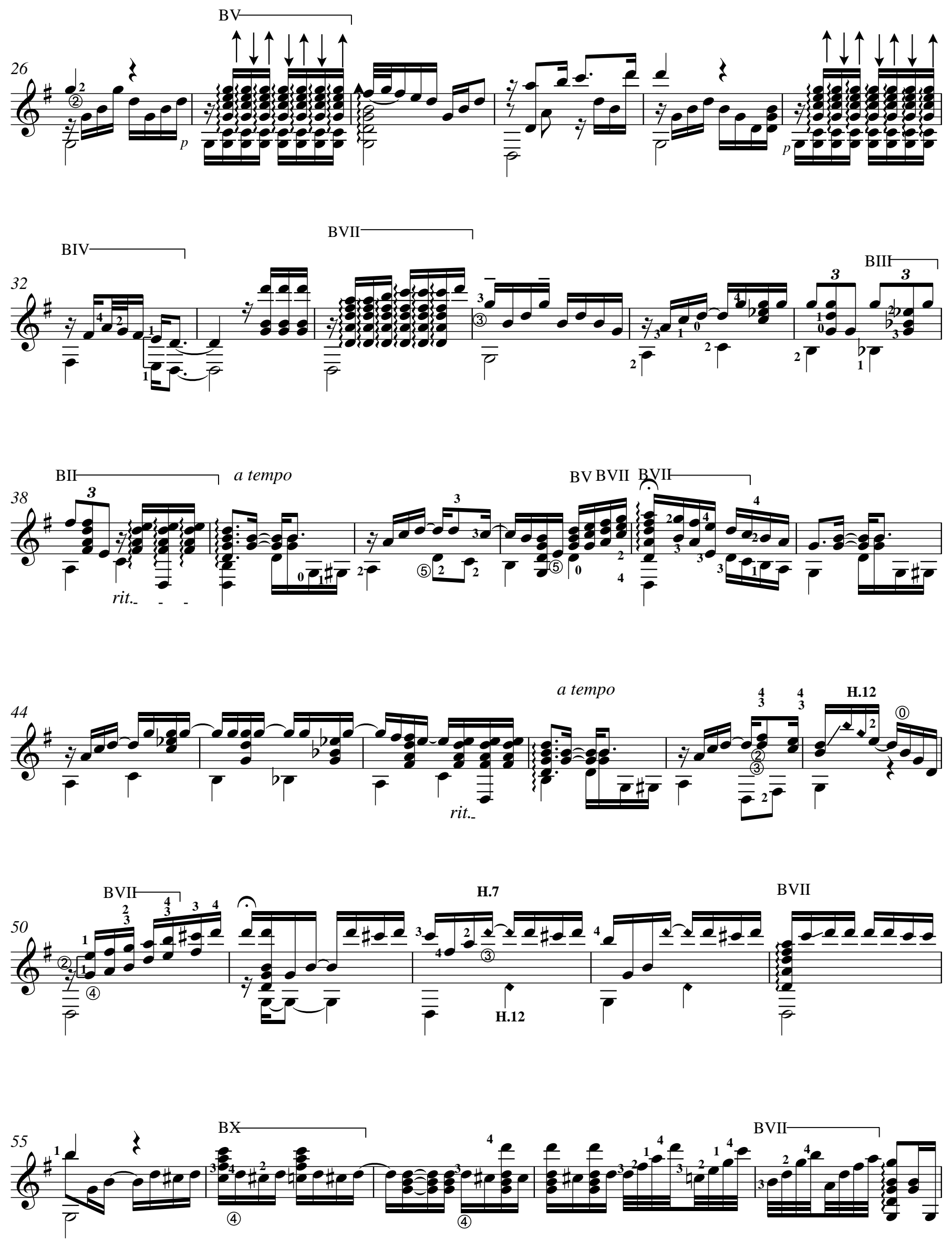

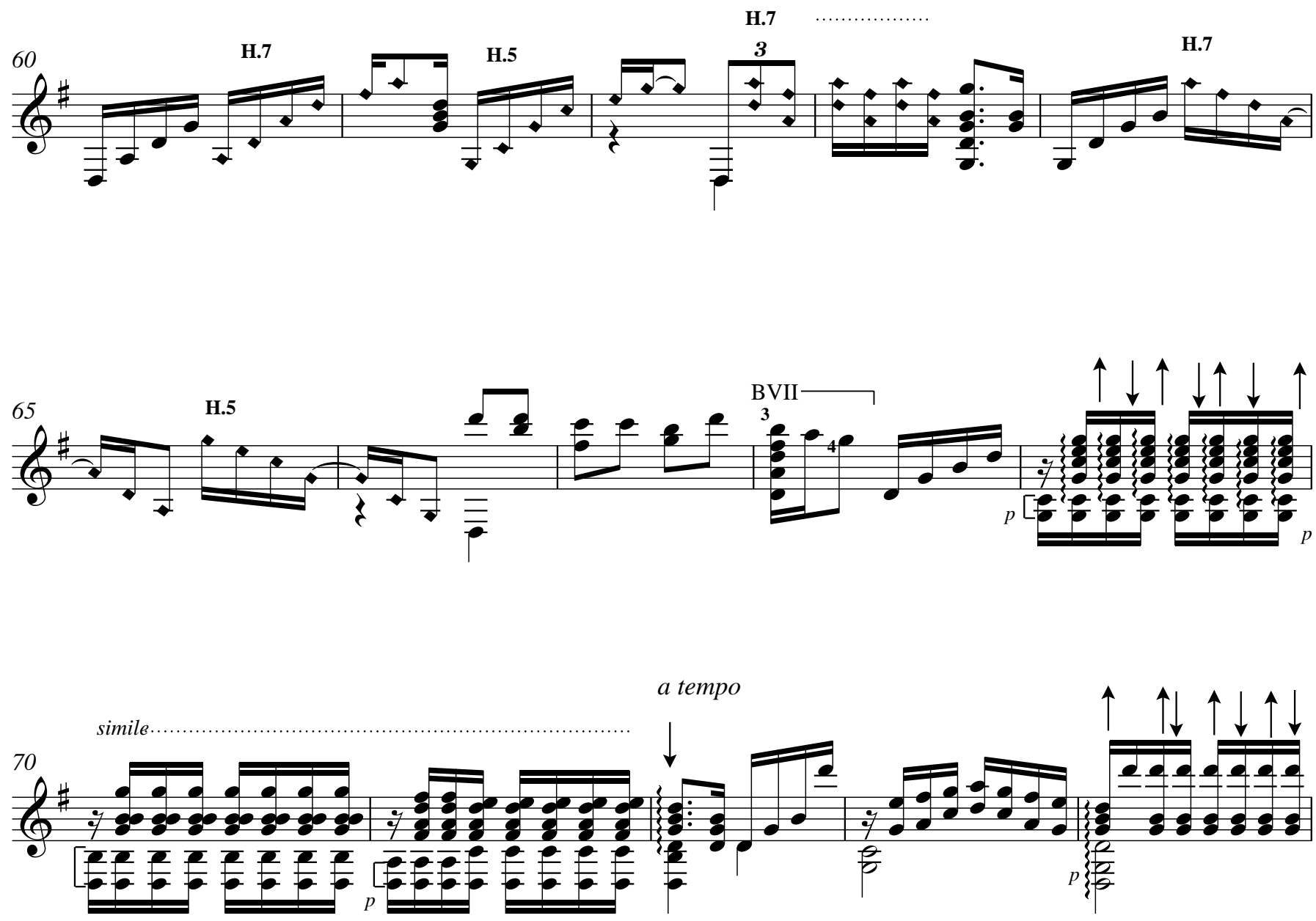

rit.

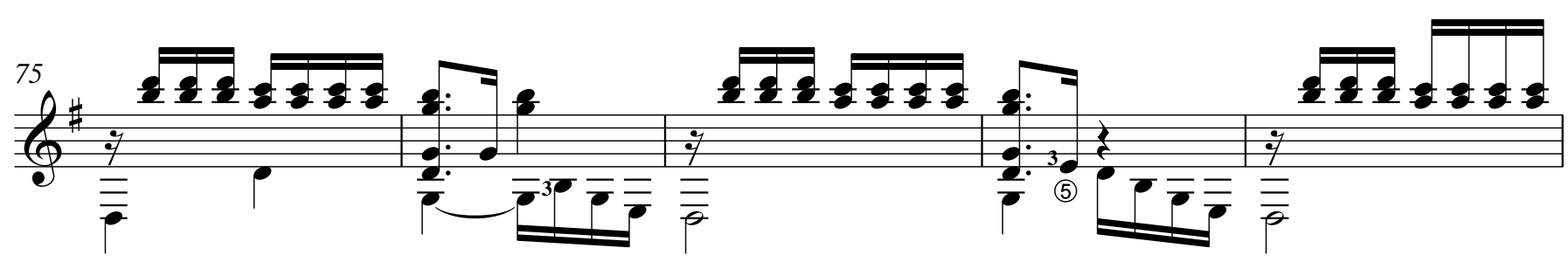

(6)

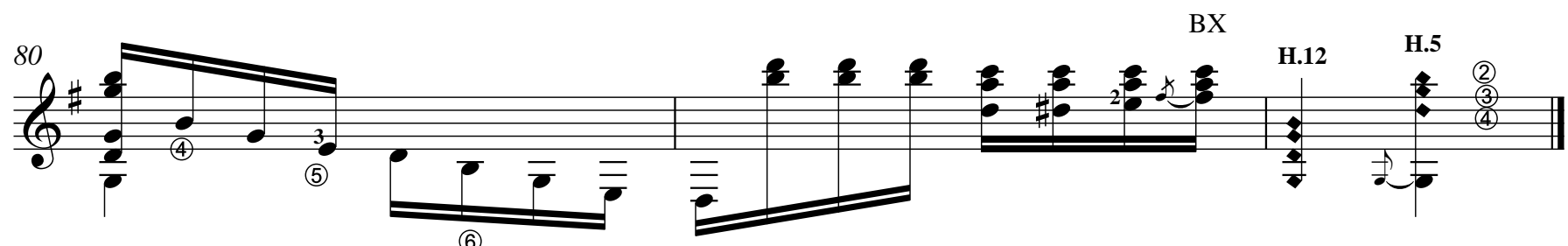

molto rit. 


\section{Conclusão}

Vimos que a obra de Salleiro revela a síntese do cenário violonístico de sua época, externando o regionalismo rítmico e temático de J oão Pernambuco; as novas possibilidades de textura, harmonia e extensão dos recursos idiomáticos do violão de VillaLobos e a utilização das técnicas e do repertório do violão clássico, que Salleiro vivenciava no Rio de Janeiro do início do século XX, através da influência de violonistas como Josefina Robledo, I saías Sávio, Maria Luisa Anido, Narciso Yepes, Andres Segovia e principalmente, conforme pudemos concluir, do universo de Agustin Barrios.

O fato de ter outra profissão que não a música fez com que Salleiro pudesse elaborar mais suas composições. Através de execuções repetidas, buscava originalidade e estilo próprio no acabamento das mesmas, apesar de não escrevê-las. Pensamos ser este também o fator que o levou a conceber uma obra exclusivamente para violão solo, já que não fazia parte dos grupos profissionais de música, os regionais, como fizeram seus contemporâneos.

Por outro lado, não depender da música financeiramente fez com que o compositor não realizasse esforços no sentido de divulgação ou preservação de sua obra, deixando que esta tenha passado quase despercebida. Não fosse pelas poucas gravações de 
Salleiro e pelas seis músicas editadas pela Casa Wehrs, possivelmente não conheceríamos sua obra.

Neste estudo, através da análise comparativa da obra de Salleiro e de seus contemporâneos, pudemos notar elementos musicais que se destacam e formam uma linguagem instrumental própria dentro do panorama do violão popular brasileiro: o uso do trêmolo, a utilização sistemática de campanellas, o abuso de harmônicos naturais e artificiais, a percussão no corpo do instrumento, os rasgueos variados, soluções harmônicas inesperadas e os procedimentos diferenciados de scordatura.

Para uma melhor compreensão dos elementos discutidos no texto, confeccionamos também um CD com as gravações de Othon Salleiro e exemplos da obra dos violonistas abordados nesta dissertação.

Julgamos ser esta pesquisa o ponto de partida para o conhecimento da produção de Othon Salleiro, pois aqui se encontram disponíveis as obras que conseguimos localizar. Acreditamos que este estudo possa contribuir para a construção da história do violão popular brasileiro, trazendo à luz a obra de um de seus importantes personagens.

Além da confecção de uma primeira catalogação da obra do violonista carioca, consideramos que a confecção das partituras extraídas da gravação do compositor é a nossa maior contribuição, 
possibilitando que esta obra passe a figurar no repertório de vários violonistas com maior freqüência. 


\section{Bibliografia}

\subsection{Livros}

ANDRADE, Mario de. Aspectos da Música Brasileira. Belo Horizonte: Vila Rica, 1991.

- (1989): Dicionário musical brasileiro (coordenação: Flávia Toni, 1984-1989). Belo Horizonte: Itatiaia; Brasília: MINC; São Paulo: Edusp; IEA-USP.

. Ensaio Sobre A Música Brasileira. 3. ed. São Paulo: Martins; Brasília; INL, 1972.

. Música e J ornalismo: Diário de São Paulo. 1. ed. São Paulo: Hucitec: Edusp, 1993.

. Música, Doce Música. 3. ed. Belo Horizonte: Itatiaia, 2006.

BANDEIRA, Manuel. Andorinha, Andorinha. Rio de Janeiro: José Olympio, 1966. $\overline{1} \overline{9} \overline{5} \overline{7}$

. Flauta de Papel. Rio de Janeiro: Alvorada Edições de Arte,

. Dialética da colonização. 10. ed. São Paulo: Companhia das Letras, 1992.

CALDEIRA, Jorge. A construção do samba. São Paulo: Mameluco, 2007.

CARVALHO, Hermínio Bello de. Mudando de Conversa. 1. ed. São Paulo: Martins Fontes, 1986.

. O Canto do Pajé: Villa-Lobos e a Música Popular Brasileira. Rio de Janeiro: Editora Espaço e Tempo, 1988.

CASCUDO, Luis da Câmara. Dicionário do Folclore Brasileiro. 11 1 a ed. São Paulo: Global, 2002.

CAZES, Henrique. Choro do quintal ao Municipal. 2. ed. São Paulo: Editora 34, 1998.

COLEÇÃO REVISTA DA MÚSICA POPULAR. Edição fac-símile 19541956. Rio de Janeiro: Funarte: Bem-te-vi Produções Literárias, 2006. 
CORREA, Sérgio Alvim. Alberto Nepomuceno. Catálogo Geral. 2. ed. Rio de Janeiro: Funarte, 1996.

COSTA, Flavio Moreira da. Aquarelas do Brasil: Contos da Nossa Música

Popular. Rio de Janeiro: Agir, 2006.

DIDIER, Carlos. Orestes Barbosa: Repórter, Cronista e Poeta. 1. ed. Rio de Janeiro: Agir, 2005.

DUDEQUE, Norton. História do violão. 1.ed. Curitiba: Editora da UFPR, 1994.

ENCICLOPÉDIA DA MÚSICA BRASILEIRA: POPULAR, ERUDITA E FOLCLÓRICA. 2. ed. São Paulo: Art Editora: Publifolha, 1988.

FERRETE, J.L. O som e a música de João Pernambuco. 1. ed. São Paulo: Discos Continental, 1979.

GARCIA, Tomas George Caracas; LIVINGSTON-ISENHOUR, Tamara Elena. Choro: A Social History of a Brazilian Popular Music.

Bloomington: Indiana University Press, 2005.

HORTA, Luiz Paulo. Villa-Lobos: Uma introdução. 1. Ed. Rio de Janeiro: Jorge Zahar, 1987.

JARDIM, Gil. O Estilo Antropofágico de Heitor Villa-Lobos: Bach e Stravinsky na obra do compositor. 1. ed. São Paulo: Philarmonia Brasileira, 2005.

KFOURI, Maria Luiza. Um breve histórico do violão; Grandes mestres. In: TAUBKIN, Myriam (Org.). Violões do Brasil. São Paulo: Myriam Taubkin, 2004. p.15-111.

LEAL, J osé de Souza; BARBOSA, Artur Luiz. João Pernambuco: A arte de um povo. Rio de Janeiro: Funarte, 1982.

MACHADO, Afonso; MARTINS, Jorge Roberto. Na Cadência do Choro. Rio de Janeiro: Novas Direções, 2006.

MACHADO, Caca. O enigma do homem célebre: Ambição e vocação de Ernesto Nazareth. São Paulo: Instituto Moreira Salles, 2007.

MARTINS, Luís. João do Rio: Uma antologia. 3. ed. Rio de Janeiro: José Olympio, 2005.

MUGNAINI, Ayrton Jr. A J ovem Chiquinha Gonzaga. São Paulo: Editora Nova Alexandria, 2005. 
NEVES, José Maria. Villa-Lobos, o Choro e os Choros. 1. ed. São Paulo: Editora Ricordi, 1977.

NEVES, Santuza Cambraia. O Violão Azul: Modernismo e Música Popular. 1.ed. Rio de Janeiro: Fundação Getúlio Vargas, 1998.

NOGUEIRA, Genésio. Dilermando Reis: Sua Majestade, o violão. 1. ed. Rio de Janeiro: Edição do Autor, 2000.

PAVAN, Alexandre. Timoneiro: Perfil Biográfico de Hermínio Bello de Carvalho. Rio de Janeiro: Casa da Palavra, 2006.

PAZ, Ermelinda A. Jacob do Bandolim. Rio de Janeiro: Funarte, 1997.

A. Villa-Lobos e a Música Popular Brasileira: Uma Visão sem preconceito. Rio de Janeiro: E.A.Paz, 2004.

PEDROSA, Henrique. Música popular brasileira estilizada. 1. ed. Rio de Janeiro: Editora Universidade Santa Úrsula, 1988.

PEREIRA, Marco. Heitor Villa-Lobos: Sua Obra Para Violão. 1. ed. Brasília: Musimed, 1984.

PEREIRA, Regina; IRATI, Antonio. Garoto Sinal dos tempos. 1. ed. Rio de Janeiro: Funarte, 1982.

PINTO, Alexandre Gonçalves. O Choro: Reminiscências dos Chorões Antigos. Rio de Janeiro: Funarte, 1978. Edição Fac-similar.

PRAT, Domingo. Diccionario de Guitarras, Guitarristas y Guitarreros. Buenos Aires: Romero Y Fernández, 1934.

PRESENÇA DE VILLA-LOBOS. 1. edição. Rio de Janeiro: MEC/Museu Villa-Lobos, vol.3, 1969.

RIO, J oão do. [Paulo Barreto]. A alma encantadora das ruas; organização Raul Antelo. São Paulo: Companhia das Letras, 1997. . Crônicas Efêmeras: João do Rio, Revista da Semana. São Paulo: Editora Giordano, 2001.

SAMPAIO, Renato. O violão brasileiro de Mozart Bicalho. 1.ed. Belo Horizonte: Hematita Edições, 2002.

SANDRONI, Carlos. Feitiço Indecente: as transformações do samba no Rio de Janeiro (1917 - 1933). Rio de Janeiro: Jorge Zahar Ed.: Ed.UFRJ, 2001. 
SANTOS, Turíbio. Mentiras... ou não? Uma quase autobiografia. 1. ed. Rio de Janeiro: Jorge Zahar, 2002.

STOVER, Richard. The Life and Times of Agustín Barrios Mangoré. 1.ed.California: Querico Publications, 1992.

TINHORÃO, José Ramos. A Música Popular No Romance Brasileiro. 1.ed. São Paulo: Editora 34, 2000.

Paulo: Editora 34, 1998.

História Social da Música Popular Brasileira. 2. ed. São

. Os sons que vêm da rua. 2. ed. São Paulo: Editora 34, 2005.

. Domingos Caldas Barbosa: O poeta da viola, modinha e lundu (1740-1800). 2. ed. São Paulo: Editora 34, 2004.

VILLA-LOBOS, SUA OBRA. 3. ed. Rio de Janeiro: Museu Villa-Lobos, 1989.

\subsection{Dissertações e Teses}

ANTUNES, Gilson. Américo Jacomino "CANHOTO" e o desenvolvimento da arte solística do violão em São Paulo.

Dissertação de mestrado. São Paulo: Escola de Comunicação e Artes (ECA), USP, 2000.

BRAGA, Luiz Otavio Rendero Correa. A invenção da Música Popular Brasileira: de 1930 ao final do Estado Novo. Rio de Janeiro, 2002.

Tese de Doutorado - Universidade Federal do Rio de Janeiro.

GLOEDEN, Edelton. O Ressurgimento do Violão no século XX: Miguel Llobet, Emilio Pujol e Andrés Segovia. São Paulo, 1996. Dissertação (Mestrado em Artes) - Departamento de Música da Escola de Comunicações e Artes, Universidade de São Paulo.

HARO, Maria. Nicanor Teixeira: A música de um violonista compositor brasileiro. Rio de Janeiro, 1993. Dissertação (Mestrado em Música) Escola de Música, Universidade Federal do Rio de Janeiro.

JEROME, David. Dilermando Reis and the valorization of the brazilian guitar. Hayward, 2002. Dissertação (Mestrado) - Califórnia State University. 
PICHERZKY, Andréa Paula. Armando Neves - Choro no Violão Paulista. São Paulo, 2004. Dissertação (Mestrado em Artes) Instituto de Artes, Universidade Estadual Paulista.

PIRES, Luciano. Dilermando Reis, o violonista brasileiro e suas composições. Rio de Janeiro, 1995. Dissertação (Mestrado em Música) - Escola de Música da Universidade Federal do Rio de Janeiro.

TABORDA, Marcia Ermelindo. Violão e I dentidade Nacional: Rio de Janeiro 1830-1930. Rio de Janeiro, 2004 Tese de Doutorado Universidade Federal do Rio de Janeiro.

\section{Revistas}

VIOLÃO E MESTRES. São Paulo: Giannini, 1964-1968. Trimestral. WADE, Graham. On the road to Magoré: how Barrios was rescued from obscurity. EGTA Guitar J ournal, Londres: n.5, p.41-44, 1994.

O VIOLÃO. Rio de Janeiro: [s.n.], n. 1-10, 1928-29.

A VOZ DO VIOLÃO. Rio de Janeiro: [s.n.], n. 1-3, 1931.

TABORDA, Márcia. A viola no Rio de Janeiro Oitocentista. Brasiliana: Revista Quadrimestral da Academia Brasileira de Música. N.24, p.1519. Dez.2006.

\subsection{Discografia}

SALLEIRO, Othon. O violão brasileiro de Othon Salleiro. Rio de Janeiro: Hi-Fi Music Disc. 2115, década de 40.

SALLEIRO, Othon. Gravação não comercial. São Paulo: RGE, 1950.

Memórias Musicais. Rio de Janeiro: Biscoito Fino, 2003.

BANDOLIM, Jacob. Gravações Originais (1949-1969). Rio de Janeiro: BMG/RCA, s/d.

REIS, Dilermando. Abismo de Rosas. Warner Music Brasil: 1996.

BARRIOS, Agustin. The Complete Guitar Recordings 1913-1942. Heidelberg: Chanterelle Historical Recordings, 1993.

TEIXEI RA, Nicanor. O Violão Brasileiro de Nicanor Teixeira. Rio de J aneiro: Independente, 1977. 
7. Anexo

Relação das músicas do CD anexo

\section{Intérprete - Música - Compositor - Ano/ Gravação}

1. J osefina Robledo - Capricho Árabe - Francisco Tárrega - S/D

2. Agustin Barrios- Tarantella - Levino da Conceição - 1928

3. Levino da Conceição - Meditando - L. Conceição - 1930

4. Regional K. Laranjeiras -. Não tens coração. A.Passos - 1908 (Quincas Laranjeiras ao violão)

5. Jacob do Bandolim - Tira Poeira - Satiro Bilhar - 1956

6. J oão Pernambuco - Sonho de Magia - J. Pernambuco - 1930

7. Dilermando Reis - Magoado - Dilermando Reis - 1961

LP O Violão Brasileiro de Nicanor Teixeira

8. Nicanor Teixeira - Berceuse - O.Salleiro - 1977

\section{LP Violão Brasileiro de Othon Salleiro}

9. Othon Salleiro - Batucada-choro (batuque) - O.Salleiro - dec.40

10. Othon Salleiro - Excelsa - O.Salleiro - dec. 40

11. Othon Salleiro - Viola da Saudade - O.Salleiro - dec. 40

12. Othon Salleiro - Ternura - O.Salleiro - dec. 40

13. Othon Salleiro - Reminiscências - O.Salleiro - dec. 40

14. Othon Salleiro - Confidencias - O.Salleiro - dec. 40

15. Othon Salleiro - Coco-baião - O.Salleiro - dec. 40

16. Othon Salleiro - Chimarrita - O.Salleiro - dec. 40

17. Othon Salleiro - Luar dos Trópicos - O.Salleiro - dec. 40

18. Othon Salleiro - Festa do Bonfim - O.Salleiro - dec.40

Othon Salleiro - Gravação RGE

19. Othon Salleiro - Quebra- Coco - O.Salleiro - 1950

20. Othon Salleiro - Toada Sertaneja - O.Salleiro - 1950

21. Othon Salleiro - Repinicado de Viola - O.Salleiro - 1950

22. Othon Salleiro - Allegro Caprichoso - O.Salleiro - 1950

23. Othon Salleiro - Devaneio - O.Salleiro - 1950

24. Othon Salleiro - Caixinha de Música - O.Salleiro - 1950

25. Othon Salleiro - Harmonia e Picardia - - O.Salleiro - 1950

26. Othon Salleiro - Dança Árabe - O.Salleiro - 1950

27. Othon Salleiro - Falando-Ihe de Amor - O.Salleiro - 1950 